

$8 \% 29 \%$ 


A

\section{SHORT TOUR IN SUTHERLAND}


Digitized by the Internet Archive in 2007 with funding from Microsoft Corporation 



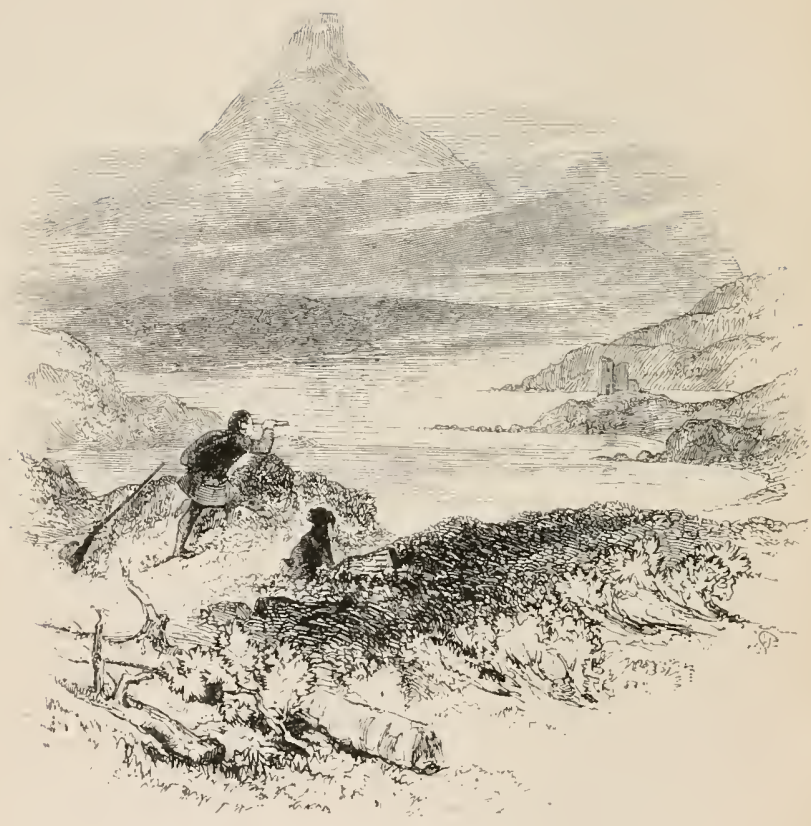

Loch Assynt.

Vol. i. Frontispiece.] 


\section{A TOUR IN \\ S U THERLA N D S IRE \\ WITH}

EXTRACTS FRON THE FIELD-BOOKS

OF

A SPORTSMAN AND NATURALIST

By CHARLES ST. JOHN, Esq.

AUTHOR OF ' WILD SPORTS AND NATURAL HISTORY OF THE HIGHLANDS'

SECONDEDITION

WITH AN APPENDIX ON THE FAUNA OF SUTHERLAND BY

J. A. HARVIE-BROWN, F.Z.S., ETC., AND

T. E. BUCELEY, B.A., F.Z.S., ETC.

IN TWO VOLS.-VOL. I.

EDINBURGH: DAVID DOUGLAS

1884 


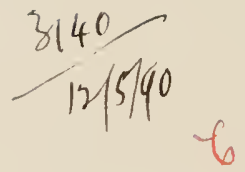

Printed by R. \& R. CLARK, Edinburgh. 
TO

HIS GRACE

\title{
THE DUKE OF SUTHERLAND
}

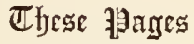 \\ ARE \\ (WITH PERMISSION) \\ RESPECTFULLY DEDICATED BY THE AUTHOR \\ HIS GRACE'S MOST OBEDIENT SERVAYT \\ CHARLES ST. JOHN.
}

January 1849. 



\section{PREFACE TO FIRST EDITION.}

IT is with real diffidence that I offer these volumes to the public. I am induced to do so by the wishes of many of my friends and companions in the woods and fields, who, having received with indulgence my former volume on Highland Sports, have persuaded me to launch another barque laden with a similar cargo of odds and ends. That it should have as favourable a voyage as its predecessor is more than I can venture to hope. If, however, these pages serve to entertain for a few hours any of my fellowlovers of nature, or if any whose occupations in life are of a graver and more laborious kind, find relaxation and amusement in their perusal, my object is fully gained. 
I do not fear the criticism of the learned; my flight is far too humble to obtain even their censure: nor do I aim at instructing any of my readers, but solely at amusing them. The scientific naturalist must excuse my errors of description and my want of skill: but thus far, and thus far only, I can venture to say a good word in favour of my rough notes - that they are the result of actual and personal observation, and not of hearsay or second-hand information; and that, therefore, some reliance may be placed in them.

The present volumes consist of extracts from a Journal, written during a wandering excursion through Sutherlandshire, one of the most interesting counties in Scotland, and one of the least known; of a series of field-notes for each month in the year, written during my residence in the pleasant land of Moray; and of a few miscellaneous 
chapters on matters of interest to the sportsman. Such as they are, I offer them to the public, trusting that they will receive them as the off-hand thoughts and observations of one who is more accustomed to the hillside than to the study-to the gun than to the pen.

[. January 1849.$]$

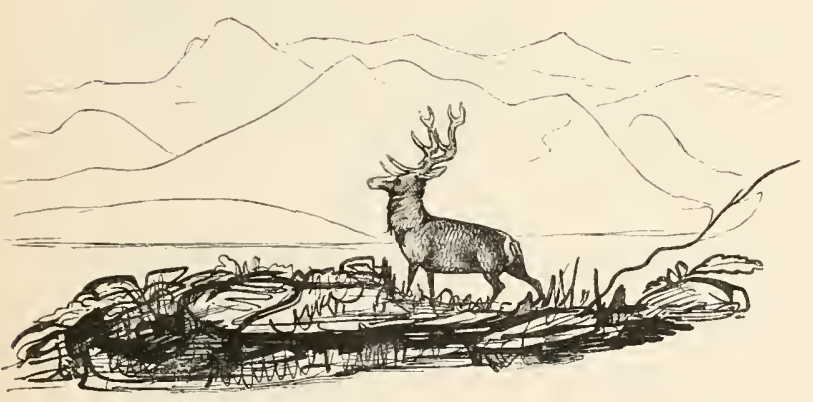




$$
\text { Sem }
$$




\section{PREFATORY NOTE.}

THE second edition of Mr. Charles St. John's Tour in Sutherland is almost an exact reprint of the original, as published in 1849. Instead of altering the text or adding fresh notes so as to bring the book up to the requirements of the day, the editor considered that it would be better to leave the work as the author wrote it, and to supplement the volumes by an entirely new chapter on the Fauna of the district. In carrying out this plan he was so fortunate as to secure the hearty co-operation of Mr. Buckley and Mr. Harvie-Brown, who have been careful students of the natural history of Sutherlandshire for the last seventeen years; the results of their experience, written from accumulated notes kept during these years, are given in the Appendix. In addition to the authorities consulted, a list of which will be found on pp. 292-3 of vol. ii., "They have VOL. I. 
received most able and willing assistance from numerous friends and correspondents either resident in, or closely connected with, the county of Sutherland; and they beg to express their thanks to Mr. Houstoun of Kintradwell, Dr. Joass of Golspie, Sheriff Mackenzie, and Mr. Hill of Helmsdale, for many valuable communications respecting the Fauna of the east and south-east districts; to Mr. Crawford of Tongue for lists and notes from the north; and to Mr. L. M'Iver and Mr. Murdoch Kerr for Fish lists from Scourie and Loch Inver. From the Messrs. Peach, and from Mr. Mackay, Portnacon, they have received most ample lists and notes on Fish of the north coast of the county of Caithness and of the Moray Firth. Mr. Mackay's notes were received too late, and were too long to print in extenso, but they hope to make a fuller use of these at a future date. From the west they have received very valuable assistance and practical aid from Mr. John Sutherland, and Mr. John Munro of Inchnadamph, both being men well acquainted with the birds of the district. Dr. Day-than whom they could not have any better authority-has most kindly looked over and revised their list 
of Fishes. Nor can they omit mention of the keepers, shepherds, and ghillies, everywhere throughout the county, too numerous to mention by name, who have so often given them a helping hand, without which many a pleasant and successful nesting expedition would have proved a failure."

The only other additions to the volumes are Capt. H. C. St. John's brief recollections of his boyhood; and the vignette illustrations from the author's sketch-books, which have been carefully drawn and engraved by Mr. John Adam, Edinburgh.

June 1884 .
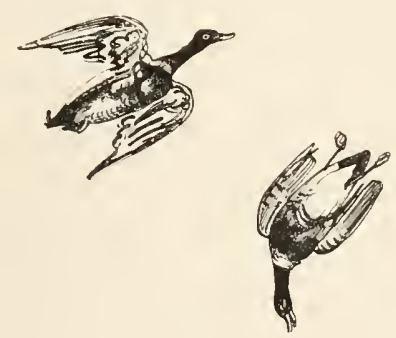
F 


\section{RECOLLECTIONS OF THE AUTHOR.}

By Captaix H. C. ST'. JOHN.

I HAVE been asked to jot down some few reminiscences of my father. I was only eighteen when he died, and as I had been to sea for four years, my recollections of him are almost those of a child.

I remember him - a slight, active man, of middle height, wiry and strong, with a handsome, animated face, blue eyes, and a singularly sweet smile. He became bald early, which showed to advantage the intellectually-formed head. In disposition he was calm and collected, and I never remember him violently excited about anything. When young, I have always heard he was gay, mixing a great deal in society; but my own recollections of him are as a thoroughly domestic man, devoted to his children, natural history, and sport. Perhaps he was rather too indulgent a father, for we boys had little difficulty 
in getting extra holidays, and this rather too frequently for our progress up the ladder of learning. In one way these holidays were not wasted; they were almost always spent with him on some long wild ramble, or shooting excursion, which he made valuable and instructive by his conversation, teaching us to observe carefully all we saw in nature. In the winter evenings he taught us drawing and chess, so graphically described by Mr. Innes in his memoir of my father. A first-rate sportsman, an excellent shot, and fond of making a good bag for home use or for friends, yet he had no delight in killing, and thoroughly disliked battue-shooting. His chief pleasure was in watching and noting the habits of all creatures ferce nature-as his books show.

I shall never forget those happy young days, when trotting in my kilt by his side, or left in the path or track by which the roe-deer would leave the wood, while he went round with the dogs to drive them to where he had placed me. In this way I killed my first deer-a feat my father was as proud of as I was.

The love of natural history fostered in us has always been of good service to my brothers and 
myself ; never have I visited any part of the world, however wanting in general amusements, without being able to find continual interest and pleasure.

Of all our many Scotch homes, Invererne was, I think, my father's favourite; it was charmingly situated, close to the river Findhorn and the large bay of that name. The wild sandhills, and the equally wild stretch of coast, made an excellent locality for the naturalist and sportsman. About a mile and a half from the mouth of the river it divides (or did so in those days), forming an island in the fork, the habitat of rabbits and all kinds of wild-fowl. Here an almost fatal accident occurred. One day, after refusing to let my brother and myself fish in the river, he took us to the island ferreting. In the course of the afternoon, without the least warning, we saw the river " coming down," like a great brown wall, ten feet high, sweeping everything before it. We had barely time to reach the highest point, for in a few seconds the island, barring a dozen square yards on which we stood, was a seething mass of water several feet deep. If we boys had been fishing nothing could have saved us. My father often spoke of this providential escape, as he did 
not anticipate the rise of the river, and had no reason for refusing our request. At all our homes we had a varied menagerie of the tamest and most intelligent of pets. He had great power and influence over animals; and his dogs, from being his constant companions, were remarkable for their sagacity. The "College," our Elgin home, rejoiced in a great walled garden of about four acres. In one part was a grass plot, where my father kept trained Peregrine falcons, which he used to fly after the fashion of bygone days, and much amusement it afforded him and us boys.

The art of training and flying hawks was taught us by our dear old friend Mr. John Hancock, the celebrated naturalist.

My father was fond of flowers, and the lighter kinds of gardening, budding, pruning, etc.

He must have been a very even-tempered man. I cannot remember a single instance of his being angry or irritable. When out shooting with him once, he caught sight of a poacher, who, on being run down, threatened to shoot my father. Giving me his gun to hold, he very quickly took the gun from the poacher, whom he simply made promise not to trespass again, and allowed him to go 
home. This was all done in the coolest manner, without anger, and with very few words.

When at Invererne he was often warned by Dr. Allan (then at Forres, since well known in London) that he was ruining his constitution by over-exposure to cold and wet, particularly in duck-shooting during the winter; but no one anticipated that fatal results were so soon to be developed.

At the time of his seizure my father was alone at the "College" (the rest of the family being at the sea-side). He then occupied an unused room-the proverbial haunted roon which belongs to most Scoteh houses. Something very strange seems to have happened to him in this room, but what I know not, as he never would speak of it. The next day he went out shooting in company with Major Campbell, and was suddenly seized with loss of power in the left side-paralysis. Strange to say, the only other time my father was in company with that gentleman he met with a very nasty accident: A dying roe-deer kicked the hunting-knife into his foot, inflicting a deep wound, severing the tendon of the big toe, which was stiff ever after. 
My poor father never regained power after his first attack, and became a confirmed invalid. $\mathrm{He}$ bore this terrible affliction for two long years with wonderful resignation and patience. The enforced idleness was particularly trying to one so active in mind and body; and yet, I believe, he never lost his cheerfulness.

I left England for China in January 1855; and in October 1856 my father died, at the early age of forty-six.

Narch 10, 1884.

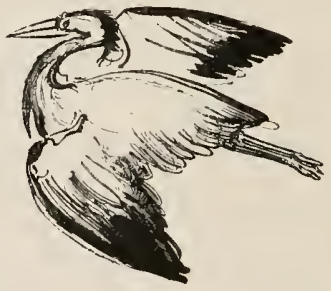




\section{CON'TENS.}

\section{A SHORT TOUR IN SUTHERLAND.}

\section{CHAPTER I.}

Sutherlandshire; its Wild-birds not sufficiently known-Our Start and Conveyance - Kyle of Sutherland - Woods of Rosehall ; old Keeper there; his recollection of me-Oykel Inn-Altnagaleanach; Origin of Name; Fishing at-Conveying Boat to Loch Urigil-Wild-geese and Divers on the Loch-Large Trout of these Lakes-Drive to Inchnadamph - Value of rare Eggs - Heronry - Peregrine Falcon and Buzzards' Nests-Climbing over the Rocks . Page 1

\section{CHAPTER II.}

Inn at Inchnadamph-Liberal System of the Duke of Sutherland-Facility of Travelling - Beauty of Country - Loch Assynt-Nest of Osprey-Large Spring of Water-Waterousel-Dense Mist-Wild Country near Kylesku_Country between Kylesku and Scowrie-Nest of Osprey ; curious position of-Eagle . . . . . . . . 18

\section{CHAPTER III.}

Inu at Scowrie-Another Osprey's Nest-The old OspreysEggs of-The River Laxford-Inn of Rhiconnich-Drive to Durness-Beauty of Scenery-Drive round Loch Erriboll- 
Glenmore-Loch Maddie-Crows-Gray Geese; time of bieeding - Old Nest of Osprey - Stag in the Loch-Fox. hound - Black - throated Divers - Aultnaharrow - Loch Laighal-Squall of Wind $\quad$. $\quad$. $\quad$. $\quad$. $\quad$ Page 29

\section{CHAPTER IV.}

Return to Sutherland-Travelling from Edinburgh - Skye Terrier; peculiarities of-Lairg-Loch Shin-River Shin -Reserve of the English-Mr. Young's Experiments respecting Salmon; Aneedotes of Salmon-Manner of Spawning; Food of Salmon-Drive to Aultnaharrow-Curlews, etc. - Loch Naver - Phalaropes - Widgeon - Green shank, etc. . . . . . . . . . 45

\section{CHAPTER V.}

Length of Day - Sedge Warbler-Different Birds near Loch Naver-Ben Cleebrick - Rain-Loch Maddie - FrostBen Laighal-Foxes-Sheep Killing-Catching Wild-ducks -Peregrine Falcon; manner of catching their Young Golden Eagles-Tongue-Fine Scenery of Bay of Tongue and Islands-Wild-cat-Seals . . . . . . 64

\section{CHAPTER VI.}

Ferry from Tongue-Difficnlties of our Start-Seals - Shepherds, etc. - Emigration - Heilam Inn - Storm - River Hope - Drive to Durness - Cave - Rock-pigeons - Inn at Rhiconnich-Search for Osprey's Nest-Swimming to Nest -Loch of the Eagle-fisher-Stalking the Osprey-Row up the Bay-Loss of Fishing-line-Scowrie-Island of Handa -Innumerable Birds, etc. 


\section{CHAPTER VII.}

Another Osprey's Nest; Variety of Eggs - Golden Eagle; Manner of Hunting; deerease of - Egg Colleetors-MIr. Haneoek's Collection-Nests of Eagles; Animals killed byThe Mountain Hare-Fishing of Osprey - Page 105

\section{CHAPTER VIII.}

County of Sutherland; Variety of Climate and Soil-List of Birds ; of Hawks ; Owls; of the smaller Land Birds ; of the Crow Tribe ; Pigeons, ete. . . . . . 117

\section{CHAPTER IX.}

List continued-Game Birds; Destruetion of by ShepherdsPlovers-Sandpipers and Snipes, ete.-Water-fowl ; Swans, Geese, varieties of Dueks, Grebes, Terns, Gulls, ete.-Deerease of many kinds of birds-Egg-dealers . . 133

\section{CHAPTER $\mathrm{X}$.}

Deer-hounds - Deer-forest in Sutherlandshire-Effeet of the Forests on Deer-The Stag easting his Horns-Hinds and Calves-Courage of the Hind--Poaehing Shepherds-Value of Horns-Fighting of Stags-Highland Forester-Breed of Deer-hounds . . . . . . . . 144

\section{CHAPTER XI.}

Agrieulture in Sntherlandshire - Faeilities of reaching the County - Caledonian Canal - Travelling in SutherlandInns, exeellent management of-Lairg-Tongue-Durness - Seowrie - Inchnadamph - Inveran - Conclusion of Sutherlandshire . . . . . . . 159 


\section{FIELD-NOTES FOR THE YEAR}

\section{CHAPTER XII.}

JANUARY.

Wood-pigeons - Fceding of Widgeon and Mallards - Wild fowl-Water-rail-Wild-duck Shooting-Change of colour in Trout . . . . . . $\quad$. $\quad$ Page 169

\section{CHAPTER XIII.}

FEBRUARY.

Change of colour in Stoats-Affection of Otters for their young -Roe-hunting-Attachment of Birds to their Mates-Food of Fieldfares during Snow - Widgeon - Wild-fowl shooting at Spynie-Incidents in Shooting-Winged Swan-CatsFood of Wild-geese-Brent Goose . . . . 178

\section{CHAP'TER XIV.}

MARCH.

Wild-swans-Loch of Spynie; Wild-fowl on it-PochardCarrion Crows - Death of Wild-swan-Domestication of Wild-fowl; flavour of-Arrival of Geese.

\section{CHAPTER XV.}

APRII.

Field-mice-Brent Geese-Arrival of Migratory Birds-Instinct of Crows in Feeding-Instinct of Thrushes-Disappointments in Shooting Wild-geese-Death of White-fronted Geese-Shetland Pony--Heronry-Anecdote of RoebuckWild-duck's Nest 


\section{CHAPTER XVI.}

MAY.

Nests of Birds-Cross-bills, etc.-Lateness of Season-Beangeesc-Partridge's Nest-Northern Diver-Coot's NestTeal and her Young-Wren's Nest-Badgers; cunning of ; anecdote of-Aurora Borealis; sound made by . Page 221

\section{CHAPTER XVII.}

JUNE,

Trout-fishing-Sea-trout in the Findhorn-Breeding-place of Black-headed Gulls - Salmon-fishing - Gray CrowsHair Worms-Fishing-Cromarty-Goats-The Peregrine Falcon . . . . . . . . . 232

\section{CHAP'TER XVIII.}

JULY.

Slore Birds; arrival of-Foxes-Herring, and Herring-fishing; Birds, etc., feeding on them-Herring - fishing in Sutherland - A Sharper-Numbers of Flounders - Young Wildfowl-Roe; habits of - Midges-Angling-Floods in the Findhorn - Prophecy of a Woman - Escape of a Sheplerd . . . . . . . . . 247

\section{CHAPTER XIX.}

\section{AUGUST.}

Golden Plover-Ring-dottrel-Migratory!Birds - Butterflies -Crabs; their manner of casting their shells - The Sea Angler - The Deal Fish - Habits of Woodcocks $A$ pet Roe - Grouse-shootings and Grouse - Wildfowl . . . . . . . . . 266 


\section{CHAPTER XX.}

SEPTEMBER.

The 1st of September-Partridge-shooting-Migratory BirdsGrouse-shooting in September-Widgeon-Jack-snipes; Breeding-places of - Landrail-White variety of the EagleSea-trout fisher-Stag's Horns-Deer-stalking-Cunning of Deer-Disappointed in getting a Shot . . Page 283

\section{LIST OF PAGE ILLUSTRATIONS.}

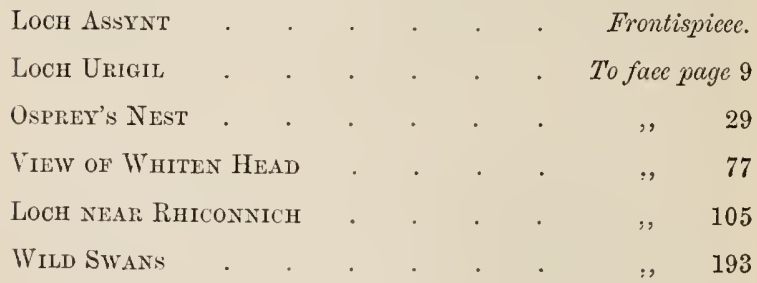


A

\section{SHORT TOUR IN SUTHERLAND.}

\section{CHAPTER I.}

Sutherlandshire; its Wild-birds not sufficiently known-Our Start and Conveyance-Kyle of Sutherland-Woods of Rosehall ; old Keeper there; his recollection of me-Oykel Inn-Altnagalcanach ; Origin of Name; Fishing at-Conveying Boat to Loch Urigil-Wild Geese and Divers on the Loch-Large Trout of these Lakes-Drive to Inchnadamph - Value of rare Eggs-Heronry-Peregrine Falcon and Buzzards' Nests-Climbing over the Rocks.

Amorgst the thousands of scenery-hunters and tourists there are very few who have ever made an excursion through the county of Sutherland, although it is a district as interesting as any in Europe, both for its magnificent and varied scenery, including sea, mountain, valley, and lake, and also as containing many rare subjects interesting to the naturalist and botanist. There are many birds and plants to be found in the wilder parts of this county which are scarcely to be seen elsewhere in Britain. The naturalist may here observe VOL. I. 
CH. 1.

closely the eagle, the osprey, the wild-goose, and many other birds, whose habits are little known, but who in this region breed and rear their young in comparative security.

The wild-cat, marten cat, fox, etc., though seldom seen by daylight, are still tolerably numerous where the ground is not kept for grousesliooting. In the latter case, however, traps and poison have pretty well destroyed these and all other carnivorous animals.

In the spring of 1848 I made an excursion through some part of the county of Sutherland, which I shall endeavour to describe, in the lope of inducing others to follow my example, being confident that whoever does so will find himself amply repaid for his trouble.

My object in making the journey was to enjoy the magnificent scenery of the north coast, to see and observe the breeding habits and localities of many of the rarer birds of Britain, and to ascertain the fact of some of these birds rearing their young in Scotland, which, from the contradictory and uncertain statements of many naturalists, seemed to be a matter of great doubt. Not being a collector of eggs or birds myself, I had no wish to destroy more of my feathered friends than sufficed to prove their identity, and to procure a few 
specimens for a gentleman who is as great a lover of nature as myself, and a far more scientific one.

Our start from Bonar Bridge was a most amusing affair, not ouly to ourselves, but also to all the inhabitants of that small but beautifully situated village.' The velicle which we travelled in was a small and lightly built flat-bottomed boat, made of larch, and mounted on wheels. It was constructed to ship and unship in half a minute. By simply unscrewing two bolts, it conld be taken off its wheels and lamnched into the water, Being on springs, it made a very easy carriage, and was large enough to hold four persons, with plenty of space for luggage. On the present occasion our party consisted of a friend of mine, Mr. J., who (although for many years a wanderer over Switzerland and many parts of Europe) had never been through the wilder and more mountainous regions of Scotland; Mr. Dunbar, whose assistance was of much use as a naturalist and interpreter amongst the shepherds and others who spoke more Gaelic than English; myself, and Leo, my retriever.

Having adjusted the liarness, traces, etc., of the boat to my horse (a stout Highland "garron"), we started at an early hour, trusting to the chapter of accidents and the pace of our horse as to where we shonld sleep that night, but determined to make 
out as many miles as we could, or in other words to advance as far as possible into the mountainous part of Sutherlandshire. Bonar Bridge is situated on what is called the Kyle of Sutherland, a narrow estuary formed by the confluence of the Shin, Oykel, Casselis, and Anak rivers, all of which streams, a short distance above Bonar Bridge, meet the salt water of the Dornoch Firth. In winter this water abounds with wild-fowl, but now (May 14) all these birds had gone to their breeding-places with the exception of a solitary godwit or two, who seemed to have been left behind the rest of their comrades, this bird not breeding in Scotland. The woods about Rosehall, or rather that portion of them which the axe has spared, used to abound in many kinds of interesting hawks, and also in marten and wild-cats, but keepers and trapping combined seen to have entirely swept all these animals away. I looked in vain for buzzards on a high rock which some few years back was invariably tenanted by them, but it seemed that they had long since been lestroyed. As I passed through the remains of the woods too I caught a glimpse here and there of passes where different stags had fallen to my rifle, and many a happy day spent in the greenwood was recalled to my recollection, with all its accompanying iucidents. I called on the old Highland 
keeper who was then my attendant, and found him exactly on the same spot where I had seen him twelve years ago, winking at the morning sun in a manner peculiar to owls and inhabitants of cottages full of peat smoke. I doubted his recognising me after so many years, but was much gratified at the pleasure and readiness with which he did so, and at the vivid recollection which he had of the corrie in which "ny honour" had shot my first stag under his guidance and tuitionhis tender inquiry too after my rifle, "the likes of which never put down a deer in the country." I returned the compliment by begging to be shown my old acquaintance, "the double-barrel," a most venerable flint gun, with singularly eccentric and unreachable triggers, which no forefinger but his own could ever pull. This ancient gur, however, in his hands had laid low many an antlered head. Though he affected to despise all new inventions, I had a recollection of his always preferring a shot with one of my percussion gums to the uncertain chance of his own flint and steel. Many an old story connected with stag and corrie, sheahing and whisky bottle, the old fellow called to my recollection; and I really saw with regret the last of his weather-beaten face, as he bowed and gesticulated to me as long as we continued in sight. I 
an afraid that my companions must have thought we a bore for a few miles, as I pointed out, with an interest which they could scarcely feel, rock and glen, the scenes of former chaces of deer, or even of the death of otter or wild-cat.

At Oykel Inn, some twenty miles from our starting-place, we stopped for an hour or two to rest our horse, and to try a cast in the river; but bright and clear as it was, with very little water in the stream, we had no success. At certain times of the fishing season there is no better river than the Oykel. May, however, is rather too early.

Eleven miles farther on we came to a small inn, at a place called Altnagalcanach,_- a most difficult and unpronounceable Gaelic name, and one which I cannot be sure of spelling right. The meaning of it is the "Burn of the Deceiver." The origin of the name, as it was told me, is amusing and characteristic enough. The place is situated in a part of Ross-shire which intrudes into the adjoining county of Sutherland in a very unceremonious manner, the cause of which was as follows:-In a dispute between the respective proprietors of that part of Ross-shire and Sutherlandshire, the marches were to be determined by reference to an old inhabitant, who, being either by clanship or bribery in the interest of the Ross-shire laird, came 
to this spot to decide the question with the soles of his shoes filled with earth from the interior of Ross-shire, the wily old fellow by this means saving himself all scruples of conscience when he swore most positively that he stood on Ross-shire ground. Standing on Pioss-shire ground in this manner, he pointed out a boundary most convenient to his employer, the Ross-shire laird. So ran the tale as it was told me; and unde derivatur the name of Altnagalcanach, which it still holds.

Close to the door of the im is a fine loch, in which are great numbers of small trout and char, and also plenty of the large lake-trout, or Salmo ferox. We fished for an hour or two, and caught a good dish of trout and one char ; a very unusual occurrence, as the char rarely rises to the fly, excepting in one or two favoured localities. Indeed I have caught hundreds of trout with the fly in lochs swarming with char without ever catching one of the latter. Though not much accustomed to travellers, the good wife of the inn put us up comfortably enough. We had clean beds, and good tea, eggs, and cream, which, with the excellent trout that we had taken, made us quite comfortable. The only thing wanting was hay (corn they had in plenty); but I soon remedied that want by shackling the horse's fore-legs with a 
couple of dog-straps, and turning him loose in the short sweet grass by the edge of the lake.

On the following morning, at the instigation of one of our party, who was very anxious to procure some eggs of the black-throated diver (Colymbus arcticus), we started for Loch Urigil, a lake about two miles from the inn. Our first step was to launch our boat in the lake, close to the door; and having crossed this piece of water, we dragged the boat out again, and, mounting it on our shoulders, carried it across the hill to the other lake. Little, however, had we reckoned on the distance we had to go.

"How far is the lake from here?" was our inquiry on leaving the water-side.

"Oh, just over yonder brae," was the answer of the innkeeper, as he pointed to a height a few hundred yards off.

"How far do you say?"

"Just a wee bit."

But that weary "wee bit" of the innkeeper's ! Many an anathema was poured on the head of our guide before we had got the boat fairly afloat in Loch Urigil. Once there, however, our cares were soon forgotten. My friend put his fishing-rod together; while I, accompanied by Mr. Dunbar, went off in the boat to the islands on the lake, in 



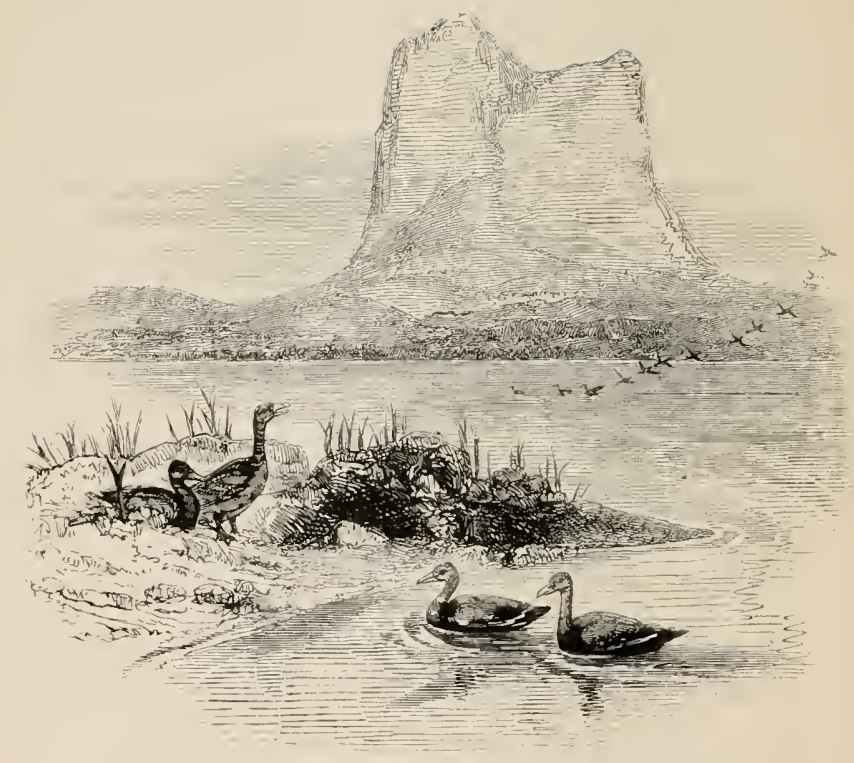

View from Loch Urigil.

Vol. i. p. 9.] 
order to see what birds were breeding there. We first made for a small island covered with the brightest green foliage that I ever saw, which, however, turned out to be nothing but the wild leek. The nature of the plant was most unpleasantly forced upon my observation by the very strong scent the leaves produced when trodden upon.

There were three of these beautiful birds (the black-throated diver) on the loch, but no eggs. On some of the other islands were a number of wild-geese (Anser ferrs), the original kind from which our common domestic goose is derived. They had two or three nests on one island, but we found no eggs. Their nests were large and quite exposed, consisting of a large mass of down, kept together by coarse grass and herbage. The old birds, when disturbed, flew off the island, some of them alighting on the loch, and others on the short green grass about the edge of the water, where they commenced grazing after the manner of tame geese. Having procured one or two specimens of the blackthroated diver, I landed, and sat down to enjoy the magnificent scenery and all its accompaniments. The peewit, redshank, curlew, and golden plover kept up a constant warfare of clamour against me for some time, till, finding that I did not molest them, they gradually returned to their domestic 
occupations. All these birds had probably eggs near the spot. After a short time they ran and walked about fearlessly, quite regardless of $\mathrm{my}$ being so near them; while the lively and restless little dunlin ran almost over my feet without fear, as I sat near the edge of the loch.

The mountains of Corgach and Assynt, some of which I could see from Loch Urigil, are of a very striking and peculiar form, standing out boldly and independently from the lower hills that surrounded them. Occasionally a curlew would come wheeling over my head, uttering its loud cry of alarm and warning, something between a whistle and a scream: but he soon sailed back to his mate on the sloping moss that covered the hill-side near the lake. A beautiful cock grouse came down within a few yards of me, and picked about amongst the stones at the edge of the water, occasionally stopping as if to exhibit himself as he stood erect with his brightred comb raised to its utmost height. When at last he saw me, instead of seeming alarmed, he rose and alighted again on a small hillock only a few feet farther off, and stood there some minutes watching me closely, and then flew off, crowing a short distance up the heather. The gray geese seemed in constant motion, sometimes feeding and sometimes flying after each other in pairs with loud cries. 
After waiting some time abont the edge of the loch I rejoined my companions, and we again renewed our portage of the boat over that weary hill. I had left a line with several hooks baited with small trout in the lake near the imn, and on leturning found a salmo ferox which weighed something above two pounds on it. While taking in the line a monster tront ran at the fish already canght, and, notwithstanding its size, nearly swallowed it, leaving the marks of his teeth in the shape of deep' cuts across the middle of the two-pound trout. I should like to have seen the fish at closer quarters who made an attack on such a goodly-sized bait, as he must have been a perfect fresh-water shark. There can be no doubt that in some of these lakes, where the water is deep and the food plentiful, these trout must grow to a size not yet ascertained. None of these lakes have ever been properly fished. A few days' trolling can never be depended on as a proof of the size of the fish in them, more particularly as we all know that the larger a tront is the less inclined is he to take any bait. I will leave it for others to judge of the size of a trout that could nearly swallow one of his own species weighing considerably above two pounds.

During our drive to Inchnadamph in the afternoon we had a fine view of Benmore of Assyut, and 
numerous other magnificent mountains, gray and dreary, and with but little vegetation of any kind, although along the edges of the lakes and streams there is always a certain width of bright green herbage, where the sheep at this season find plenty of good grazing. The long ranges of cliff-like rocks near Inchnadamph are very splendid in their height and shape, and are frequented by buzzards, ravens, gray crows, and a pair of peregrine falcons. Notwithstanding all these enemies the ring-ousel sings from every green corner of the rocks, while wheatears (safer perhaps from their smaller size and their habit of dodging under the stones) are extremely numerous everywhere along the road side. At Inchnadamph we arrived late in the evening, and found a comfortable, clean inn, an obliging landlord, and all the accompaniments that one could wish to refresh both mind and body (I am afraid that the former is sadly dependent on the latter), at the end of rather a hard and long day's work, for we had been actively employed from daylight.

The black-throated diver (Colymbus arcticus) is a peculiarly beautiful and singularly marked bird. Though generally rare, in certain localities which happen to be adapted to its habits this bird is not unfrequently to be found during the breeding season. It invariably breeds on some small, flat 
island in an inland lake; it prefers, and indeed is seldom found except in, lakes which lie in a flat or open part of the country, and which have shallows and grassy creeks, as it feeds more on frogs, leeches, and similar productions of such places than on the trout that frequent the more stony and deeper parts of the lake. Apparently from the position of its legs and feet, this diver camnot walk on land, and therefore places her egros within a very few feet of the water's erlge on a flat island where it can reach them by a kind of waddling, seal-like 1notion. I never found above two egrrs in a nest, and do not believe that they ever lay more, although I have been told of three having been procured. The egrs is of a long and regular oval form, and large; the eolour is a fine rich brown green with darker spots. This bird appears to have great difficulty in rising from the water on a caln day, and sometimes nothing will induce it to fly, although when once on wing it flies strong and high. When two or more are in company I have never seen them rise; they appear then to trust more to diving for safety; but when a black-throated diver is alone he will frequently take to flight most mexpectedly and leave the loch altogether. Unluckily, the very great beauty of its plumage, and the rarity and difficulty of procuring it, make this interesting bird 
an object of pursuit amongst bird-stuffers and collectors, and this, combined with the price offered for its eggs by egg collectors, will soon entirely extirpate it from all its present breeding-places.

The cry of this diver is loud, peculiar, and mournful, and it has acquired the local name of rain-goose among the Highlanders, owing to its habit of uttering its croaking call with great perseverance before rain or stormy weather. Its other local and Gaelic names signify the loch hen, and the great loch hen, in distinction to the red-throated diver, which is also frequently found in this county. The latter bird (Colymbus septentrionalis) is much commoner, and is neither so large nor handsome a bird as the former. It is also distinguished readily by the light brownish red neek. The red-throated diver breeds often near small pools and lochs, and lays its eggs more frequently on the shore of the mainland surrounding the loch than on an island. It is not so shy a bird as the black-throated diver, but not being so much valued by collectors, has, I hope, a chance of existing some time yet as an inhabitant of Britain during the breeding season.

I found that all the shepherds, gamekeepers, and others in this remote part of the kingdom had already ascertained the value of the eggs of this and other rare birds, and were as eager to search 
for them, and as loth to part with them (excepting at a very high price), as love of gain could make them. Nor had they the least scruple in endeavouring to impose eggs under fictitious names on any person wishing to purchase such things. Indeed I an very sure that many of the eggs sold by London dealers are acquired in this way, and are not to be in the least depended on as to their identity.

I was told of a singular heronry situated on a lake between Oykel and the imm at Altnagalcanach, where the herons breed in great numbers on the ground in an island on the loch. The place being situated at some distance from the road, I had not time to look for it, much as I should have liked to have seen the heron building in such a situation; but as we drove along I saw several herons winging their heavy flight towarls the place where I was told this lake was situated.

Before we started from Inchnadamph, wishing to procure some eggs of the peregrine falcon, who bred in the cliff near the inn, I procured the assistance of two or three people, one of whom, a young man, son of the innkeeper, volunteered to go over the face of the rock with a rope round his waist, we holding it from above. As it was not only rainy but extremely windy, I was not very 
willing for him to do so. However, as he seemed quite confident in the steadiness of his own head and footing, we prepared to perform our share of the work. Having fastened the rope securely round his body below his arms, we lowered him gradually over the summit, immediately above the nest of the buzzard. He was provided also with two or three joints of a fishing-rod, and a kind of tin soup-ladle (bearing in this country the quaint name of a "kail-divider"), which was fixed into the small end of his rod. The use of this was to enable him to spoon the eggs out of the nest, in case it was placed, as the nests of these birds often are, so far under a shelf of rock as to be inaccessible without some such contrivance. Over he went then without the smallest hesitation or nervousness, notwithstanding the slippery state of the whole rock and the violence of the wind. We lowered yard by yard of the rope, till he looked like a spider hanging at the end of its thread. He then was quite lost to our view, having scrambled under some projecting rocks to reach the nest. After a few anxious moments he gave the agreed upon signal for being drawn up, and I must say that I was rejoiced when his head appeared again safe above the edge of the cliff, holding in his teeth his cap, in which he had deposited the eggs. 
We found that the peregrine's nest would have been quite inaccessible even to our experienced and bold climber but for his long spoon.

All the time that we had been engaged at the buzzard's nest two pair of hawks were hovering about us, keeping certainly at a respectful distance. It was interesting to observe the different flights of the two kinds of hawk-the buzzards sailing to and fro with slow but powerful wing, and wheeling in large circles; while the peregrines dashed about, turning with rapid and sudden swoops, sometimes below us and sometimes suddenly shooting high up into the mist, when we could only tell their exact situation by their shrill and angry cries. The buzzards uttered a kind of low complaining cry, of quite a different expression and note, as they floated to and fro below us.

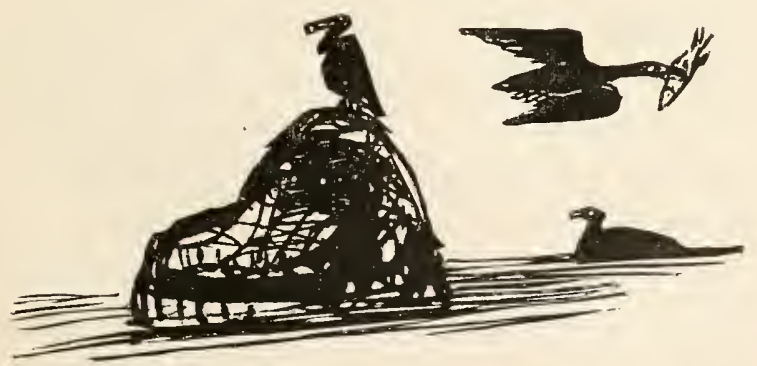

VOL. I. 


\section{CHAPTER II.}

1111 at Inchnadamph-Liberal System of the Duke of Sutherland-Facility of Travelling - Beauty of Country-Loch Assynt-Nest of Osprey-Large Spring of Water-WaterOusel-Dense Mist-Wild Country near Kylesku-Country between Kylesku and Scowrie-Nest of Osprey; curious position of-Eagle.

BEING under a good and liberal landlord is like being under a good and liberal government; and this we found to be the case at Inchnadamph, which is held under the Duke of Sutherland, or (as he is equally well known here) the "good Duke"-a title, by the way, his Grace may be prouder of than any other that could be invented. Throughout the Duke's property here the innkeepers hold their houses (and capital ones they are) rent free, and lave certain other advantages in hiring their land, and in having every encouragement that the most kind and judicious liberality of the proprietor can give them, on (I believe) the express condition that their inns should be decently kept and the charges moderate. The consequence of which arrangement is that strangers can travel through this otherwise wild and lonely country with every facility and comfort, 
and without the disagreeable feeling of being doubly overcharged because they are strangers. Nevertheless, with all this facility and comfort, but very few strangers do come to see this magnificent scenery, simply, I fancy, because it is little known and not yet the fashion. Most visitors to the Highlands drive straight from their home in England or elsewhere to the ground which they have hired for grouse-shooting or other sporting, and after a certain number of weeks drive straight back again. Very few travel here for the sake of seeing the wild scenery of the north and north-west part of the island, where there is little in the way of game to tempt sportsmen. To me, however, it is the most attractive part of Scotland; and the season I delight in most is during the months of June and July, when the sun scarcely dips below the horizon and it is light during the whole night-light enough, indeed, to read small print with ease without the aid of candles or even of the moon. Backed by that fine old-looking mountain Benmore of Assynt, the inn at Inchnadamph has for its front view the beautiful and extensive loch of Assynt, and one of the finest mountains in the North, called by a name that sounds like Coignaghin. To my English ears, however, the name was quite mattainable. This mountain towards its summit forms a singularly-shaped 
cliff, round which I have generally seen one or two golden eagles soaring with strong and majestic flight.

At Loch Assynt, on a peninsula (once an island, and now occasionally so), there are the ruins of an old castle. On the summit of the lighest part of the wall is an immense pile of weather-beaten and bleached sticks, which two years ago formed an osprey's nest, but, unluckily, this most interesting bird has been killed or driven from its picturesque and exposed dwelling-place. Nothing could be more characteristic of the bird than this nest perched on the highest corner of the ruin, overhanging the broad lake, which abounds with trout of all sizes. The Salmo ferox, or great lake trout, is more plentiful in Loch Assynt than in most Highland lakes. A short distance above the inn at Inchnadamph a spring rises from the limestone rocks which it is worth travelling from London to see. Direct from the ground bubbles up this spring with such power and abundance that it at once forms a goodly-sized brook of the most pure and transparent water that can be imagined. The smallest trout or the smallest pebbles are seen as clearly in its deepest pools as if no water intervened. So bright and clear are the streams flowing out of limestone, that they have rather the effect that a good glass has on a picture than that of making objects indistinct. 
We started from Inclnadamph inn in good time in the morning, intending to reach Scowrie, about twenty-one miles distant; but the road being very hilly, and a ferry intervening, we had to reckon on many hours of travelling before we reached our night's quarters. I walked on to look at the osprey's nest on the old castle, and an interesting sight it is, though I lamented the absence of the birds. Why the poor osprey should be persecuted I know not, as it is quite harmless, living wholly on fish, of which every one knows that there is too great an abundance in this country for the most rigid preserver to grudge this picturesque bird lis share. The fact probably is that his skin is wortl something to keepers and others, as they can always get a few shillings for it, and therefore the bird is doomed to destruction. The "auri sacra fames" will soon put an end to his race in this country.

In the midst of a steep and tolerably high waterfall, perched on a small piece of projecting rock, and surrounded by the dashing water, I saw one of my favourite birds, the water-ousel, his white breast conspicuous even amongst the white foam. A twisted birch and a bunch of bright green fern growing out of the rock, constantly watered by the spray of the fall, made as pretty a little scene for a painter as I ever saw. Water-ousels seem to prefer 
picturesque dwelling-places, or rather, I suppose, they choose such spots as being better suited for placing their curious-shaped nest in than any other.

While I was examining a kind of simple but most serviceable stone-mill, used for grinding the stone of which these excellent roads are made, the carriage came up, and we proceeded. Coming to a road leading off the main one, and going straight up a hill northwards, Dunbar assured us that this was our route; so with rather an envious look at the straight level road before us which we were leaving, we turned our faces to the hill. After going about two miles, not quite perpendicularly (the way gradually getting worse), we suddenly came to an abrupt termination of the track. Through the driving mist, which had now become quite thick, we saw a most desolate-looking house some few hundred yards off, and there found that we had turned off the road too soon, and had to retrace our steps.

The next turning off was the right one, and we laboured again up the hill, northwards, but with a better road. The higher we ascended the denser was the mist; and though we occasionally heard the grouse-cock crow pretty near us, we could see nothing, absolutely nothing, except the road under our feet. 
I was amused by my friend's good-natured philosophy: when I lamented loudly the curtain of mist which was entirely shutting out the magnificent hill under which we were then passing, he comforted me by saying that he preferred almost the scene as it then was (the mist occasionally giving us a momentary peep at some gray rock, and then shutting it out), as it added a kind of mysterious interest to the wild scenery through which we were passing.

After working our weary way up hill for some time we crossed the highest ridge of our road and began to descend towards the ferry of Kylesku, by which we were to pass an arm of the sea that runs a considerable distance inland. As we came lower the mist gradually disappeared, and at last we were fairly out of it, although it remained as dense as ever above us, quite concealing all the higher grounds. I never saw such a confusion of rock and stone as we passed through for some two or three miles. The rocks seemed to have been splintered and broken up by some great convulsion of the earth; all looking broken and angular, none of them wearing a round weather-worn appearance, or being much overgrown with heather or herbage.

Eagles are by no means scarce in this part of the country, but as they hunt principally in the 
higher districts, they are not seen so often as might be expected, excepting by an eye that is accustomed to them.

Having rested our horse and drank tea (the only meal we could get) at the ferry-house, we managed to persuade the landlord, who was also ferryman, to leave the hot whisky and water which he was drinking with some acquaintance of his own at that hour, twelve A.N., and ferry us across.

We entered into conversation with a shepherd on the north side of the ferry, who told us of a nest of the "Eagle Fisher," as he called it, on an island in a loch not very far from the road; so we appointed the man to meet us the following morning at a certain place, and drove on to Scowrie, through a succession of the most wild and rocky passes, along which the road is carried with a skill that does infinite credit to the engineer who formed it. Occasionally the scene is varied by glimpses of the sea, studded, as it there is, with islands. The country continues still of the same aspect; consisting of the most confused and disorderly chaos of broken and rugged rocks, but with rank heather and warm sheltered corners and nooks, with little clumps of birchtrees already in full leaf. Many, too, of the innumerable deep-looking lochs by the roadside have islands covered with birch and rank heather-the 
haunts of numbers of otters. There seems a great scarcity of birds of all kinds; which is accounted for by the number of marten and wild cats who live here, amongst the great and nearly inaccessible masses of rock, in the most perfectly undisturbed security. Cuckoos, wheatears, and ring-ouselsseemed to be almost the only feathered iuhabitants, with an occasional pair of ravens or peregrine falcons.

The inn at Scowrie, kept by a man of a most un-Highland name, viz., "Tough," is excellent, and most cleanly and comfortable did we find it, and the people full of civility. Unluckily there were two shiploads of emigrants on the point of leaving a harbour near Scowrie, and their friends were wishing them a good voyage in many a bumper of whisky, with the usual accompaniment of bagpipes and reels; so that what with their songs, their music, and the beating of their feet, as they danced under the inspiration both of whisky and pipes, there was a tolerable noise kept up till daylight. But mountain travelling and a feeling that it was impossible and unjust to be angry with the poor fellows enabled me soon to sleep as comfortably as if all had been still. At daylight, according to appointment, I started with Mr. Dumbar in the boat, but drawn by a small Highland pony whose services we had engaged, for the purpose of getting to the nest of the "Eagle 
Fisher," as the osprey is sometimes called in Gaelic. At the nearest point of the road to the lake we unshipped the boat, and making traces out of rope, we fastened the pony to it, leaving the under carriage and wheels by the roadside; we then managed to get the boat to the water's edge, the pony scrambling, in a manner practised only by mountain-bred ponies, over bog and rock, dragging the boat after him, while we did our utmost to keep it from injury, or from getting stuck in the rough ground.

I was delighted beyond expression at seeing the two ospreys, one of them on the nest and the other soaring above the loch, uttering cries of alarm at our approach.

The nest was placed in a most curious situation. About a hundred and fifty yards from the shore there rose from the deep water a solitary rock about ten feet high, shaped like a broken sugar-loaf or truncated cone : on the summit of this was the nesta pile of sticks of very great depth, evidently the accumulation of many breeding seasons, as the osprey returns year after year to the same nest. How this heap of sticks withstood the winter gales without being blown at once into the water puzzled me. In a crevice of the rock was a small tuft or two of green, otherwise it was perfectly bare and steep. We launched our little bark and were soon 
pulling strongly against a liead wind across the loch. The female osprey allowed us to approach - within two hundred yards or so, and then leaving her nest, sailed upwards with a cirching flight till she joined her mate high above us.

Having reached the rock, and with some difficulty ascended to the nest, our disappointment may be imagined when we found it empty. From the old bird having remained on so long, we had made sure of finding eggrs in it. The nest itself, however, was interesting to me, perched as it was on the very summit of the rock, and composed of large sticks, every one of which must have been a heavy burden for a bird of the size of the osprey. In the centre of the pile of sticks was a cupshaped hollow, the size of a boy's cap, lined with moss and dead grass, and apparently quite ready to receive eggs. It was of no use lamenting, so we turned our boat towards the landing-place, and drifted back quickly and in silence. Some hooded crows, perceiving that both the ospreys were off their nest, immediately made a dash towards it, and I was much amused at seeing the skirmishing between these mischievous and cunning marauders and the two ospreys; the latter fighting simply pro aris et focis, having no eggs or young to defend; while the crows fought lustily in the hope only of 
finding something in the nest, calculating, probably, as we had done, that the ospreys would not have been sitting on an empty nest.

On returning to the inn at Scowrie I found that my friend had been more profitably employed in catching a dish of fine-looking though muddy tasted trout in a small rushy loch close to the inn.

One of the Duke of Sutherland's foresters brought in a very fine white-tailed eagle, which he had shot the day before: unluckily the plumage was quite destroyed in consequence of the keeper having, to "make sure," discharged his gun at the bird a second time after it had fallen, in consequence of which the head was nearly blown off. I procured, however, some feathers for the large salmon fly which we fish with in the Spey river, in making which the eagle's feather is the principal material employed.

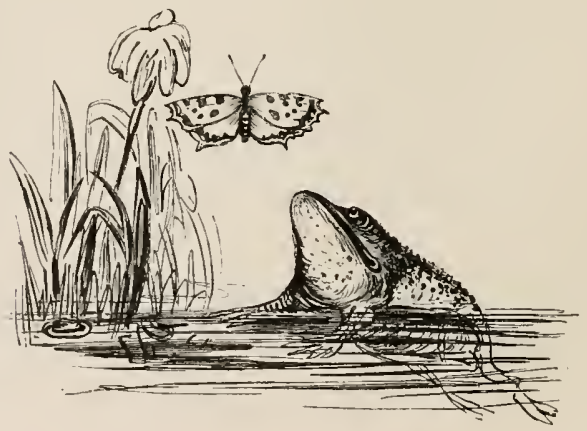





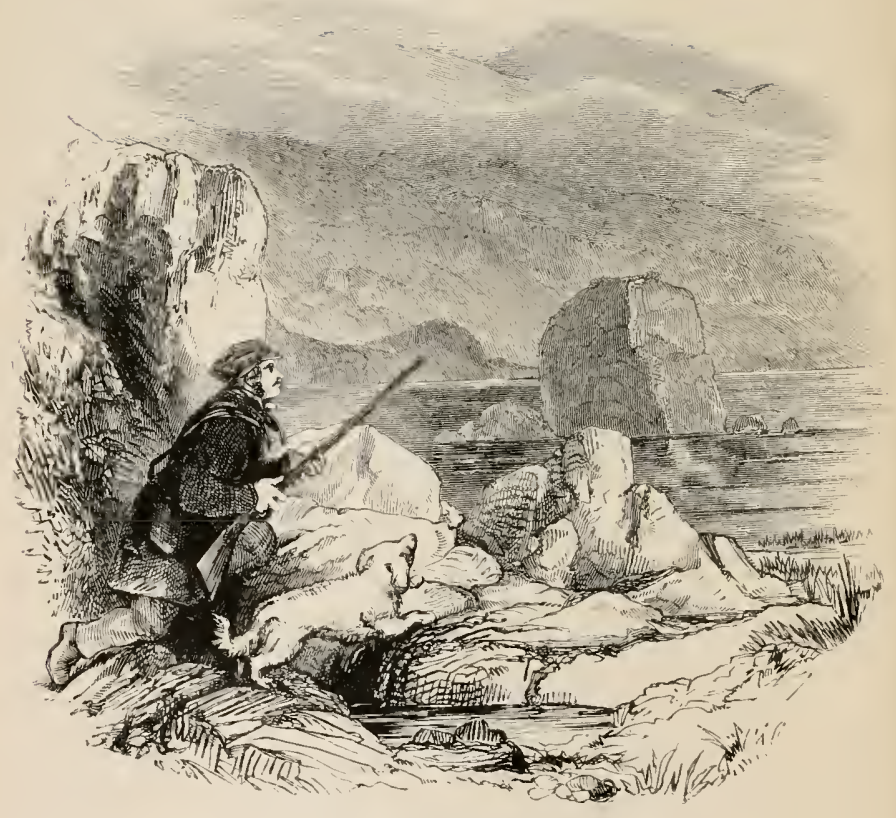

Osprey's Nest. 


\section{CHAPTER III.}

Inn at Scowric-Another Osprey's Nest-The old Ospreys; Eggs of-The River Laxford-Inn of Rhiconnich-Drive to Durness-Beauty of Scenery-Drive round Loch ErribollGlenmore-Loch Maddie-Crows-Gray Geese; time of breeding - Old Nest of Osprey-Stag in the Loch-Foxhound - Black - throated Divers - Aultnaharrow - Loch Laighal-Squall of Wind.

WE were loth to leave our comfortable hostel at Scowrie, particularly without visiting the island of Handa, a great breeding-place of sea-fowl; but being rather pressed for time, we got again under weigh for Durness. Our landlord at Scowrie having told us that he had heard that the osprey was building on an island in a loch about a mile from our road, we left the horse and boat under charge of a bare-legged and bare-headed boy at the place he mentioned (a small bridge about three miles from Scowrie), and went to a point of rock, from which we could command a view of the loch in question. We immediately through a glass discovered the nest of the osprey, built in exactly a similar situation to the last; that is, on the summit of a rock about eight feet high, shaped like a truncated cone, and standing exposed and alone in the 
loch. On coming nearer we could distinguish the white head of the female osprey on the nest. The male bird was not in view. It was determined that I should remain concealed near the loch, while my two companions went for the boat. This plan was adopted for the double reason that I might be at hand to shoot any hooded crow who might attempt to take the eggs while the osprey was off, she having left the nest on our approach, and also that I might have a chance of shooting the old osprey herself in case she came within shot. I must say that I would rather she had escaped this fate; but as her skin was wanted, I agreed to try to kill her.

For some time after the departure of my companions she flew round and round at a great height, occasionally drifting away with the high wind, and then returning to the loch. She passed two or three times not very far from me before I shot at her. But at last I fired, and the poor bird, after wheeling blindly about for a few moments, fell far to leeward of me, and down amongst the most precipitous and rocky part of the mountain, quite dead. She was scarcely down behind the cliffs when I heard the cry of an osprey in quite a different direction, and on looking that way I saw the male bird flying up from a great distance. As he came nearer I could distinguish plainly with my glass that he 
CHI. III.

was carrying a fish in his claws. On approaching he redoubled his cries, probably expecting the well-known answer or signal of gratitude from his mate; but not hearing her, he flew on till he came immediately over the nest. I could plainly see him turning his head to the right and left, as if looking for her, and as if in astonishment at her unwonted absence. He came lower and lower still, holding the fish in his feet, which were stretched out at full length from his body. Not seeing her, he again ascended and flew to the other end of the lake, the rocks echoing his shrill cry. The poor bird, after making one or two circuits of the lake, then flew away far out of sight, still keeping possession of the fish. He probably went to look for the female at some known and frequented haunt, as he flew rapidly off in a direct line. $\mathrm{He}$ soon, however, came over the lake again and continued his flight to and fro and his loud cries for above an hour, still keeping the fish ready for his mate. I at length heard the voices of my friends, and we soon launched the boat. The osprey became much agitated as we neared the rock where the nest was, and dropped the fish he held into the water. We found two beautiful eggs in the nest, of a roundish shape; the colour white, with numerous spots and marks of a fine rich red 
brown. As we came away we still observed the male bird unceasingly calling and seeking for his hen. I was really sorry that I had shot her.

This excursion to the lake hindered us so long that, after resting our horse at Rhiconnich, we did not reach Durness till late at night.

From Scowrie to Durness, particularly about Rhiconnich, the road winds through a constant succession of the most rocky, rugged, and wild glens that it is possible to imagine, with here and there beautiful sheets of water, deep, and darkly shaded by the overhanging rocks, and occasionally by small birch-woods. Winding round near the mouth of the Laxford river, we saw an osprey fishing in, or rather over, the pools near the bay. I am told that the Laxford is one of the best, if not quite the best, sea-trout stream in the North. There are gloriously wild and rocky mountains rising from the landward side of the road, with the most fantastic and picturesque outlines. The bay at Rliconnich, too, is very beautiful. The whole road, indeed, commands one constant and endless succession of scenery equally magnificent and wild; nor does the traveller drive a mile throughout this journey without some new and most interesting view-varied, too, as it is by rock, water, and mountain, by the rich brown of the heather, the vivid green of the birch- 
woods, and the grassy banks of some of the streams, and also by the deep blue of the lochs. The eye never wearies of being kept constantly occupied in admiring the surrounding objects. I shall not forget, however, one part of our drive between Rhiconnich and Durness, where the road passes over a wild and dreary hill-side, at a considerable height above the valley below us. Here for some miles we were exposed to the coldest and most driving and wettest mist that ever disgraced a May day. Nothing could be seen twenty yards from the road excepting the drifting clouds. Luckily the wind was behind us, as it would have been almost impossible to have faced it. It cleared off again, however; and before we reached Durness the night was as calm and bright as the morning had been. We did not arrive at Durness till eleven at night, and then we found no one up; indeed we had great difficulty in finding the inn, as there was nothing to distinguish it from any other house in the scattered village, excepting that it was considerably larger than its neighbours. After some time, however, we did find one person awake, and got comfortably housed in this very excellent inn.

Nothing can exceed the sea view from Durness, as you look along the varied line of abrupt rocks to the cliff called "Far-out Head," which is very VOL. I. 
nearly if not quite as northerly a point as Cape Wratl.

Having passed the end of Loch Erriboll, and having procured a feed of corn for our horse from Mr. Clark (the tenant of the sheep farm here), we worked a zigzag course up the largest and steepest hill we had to contend with throughout our whole journey. Then descending, we passed the face of a hill, cut and intersected by numberless small streams of the most pure and transparent water that I ever saw, which take their rise from the limestone rocks above.

Loch Erriboll is one of the numerous creeks reaching into the mainland from the North Sea, and often serving for a refuge to shipping, which otherwise must inevitably perish in every violent north and north-east wind on this iron-bound coast. On our way from this loch we passed the head of a fine fresh-water lake, Loch Hope, and up a magnificent glen called Glenmore (I believe), the sides of which, woody and precipitous, abound in the wilder fer naturce of the island. Wild and marten cats live here in peace, and we frequently saw eagles sailing about the higher cliffs, and sometimes perched on some pimnacle of rock. We found out by chance a very perfect echo, repeating every word, and even sentences, with the greatest exactness, and 
passing from one side of the valley to the other till the sounds died away in an indistinct murmur. - After emerging from this splendid strath we arrived at the edge of a wide loch with many green islands on it, called Loch Maddie. Here again we put our boat afloat, and leaving our luggage, etc., under charge of Leo, while J- fished, Mr. Dumbar and I went to search the islands in order to discover what birds were breeding there. We found several hooded crows' nests in the birchtrees on the islands, where they had hitherto lived and plundered in perfect security. However, we destroyed their eggs and young without mercy, and shot the birds themselves whenever and wherever we could.

The hooded crow is the only bird against whom I wage constant and unpitying warfare; I lave so constantly detected them destroying my most favourite birds and their eggs, that I have no pity on them. We also found in these islands many nests of the Gray lag goose. To make sure of the species I shot some of the old birds, it having been rather a disputed question amongst several of my friends whether the goose breeding in this country is the Gray lag (Anser ferus) or the Bean goose (Anser segetum). All the geese on Loch Maddie were the Gray lag; indeed I never saw any of the Bean 
geese breeding in Sutherland, excepting on the islands of Loch Shin, ${ }^{1}$ where a few still breed annually in spite of the constant and cruel warfare waged against them. The number of eggs in each nest was from four to seven, and they had all been apparently sat upon for some time: indeed we found one brood of young birds at least four or five days old. This being on the 18th of May, proves that this bird arrives at its breeding-place very early. A goose sits a month, so that supposing these young birds were four days old, it carries back the time when the old bird commenced sitting to the 14th of April; and then allowing ten days for the bird to prepare her nest and lay her eggs, the Gray lag goose cannot arrive at the breeding-places later than the 1 st or $2 \mathrm{~d}$ of April. The Bean goose arrives in Morayshire and that part of Scotland from the south as nearly as possible in the third week of March, their arrival a few days earlier or later depending on the state of the weather; and the flocks do not leave that country till the 29th or 30th of April, some few even remaining several days afterwards. This fact shows a great distinction in the habits of the two kinds of geese; for while the Bean goose (Anser segetum) is still

1 An error. The Bean goose breeds nowhere in Scotland. J. A. H. -B. 
fattening on the oat and pea fields, the Gray lag goose (Anser ferus) has already laid, and is nearly liatching her eggs, in the wilds of Sutherland. In one island, containing a few stunted birch-trees, we saw an old osprey's nest, not now tenanted; but I am told that the old birds were inhabiting it two years ago. The nest was most interesting : it was placed in a fork of the tree so low that we could see into it without climbing, and it consisted of a perfect cartload of sticks, varying from the size of a very stout walking-stick down to the twigs of birch and heather of which the inner part of the fabric was composed. I did not measure the nest, but as nearly as I could guess, it was not less than eight feet in length and nearly four in width; the depth, too, was very great; the inner lining was composed of a coarse kind of grass that grows in these islands. Although the nest must have weathered many a winter storm of wind, snow, and rain, and was quite bleached, it was still fixed firmly in the fork of the birch-tree. To have seen the ospreys building up this great and strong mass would have repaid one for a journey of many a long mile.

Wilson mentions that in America the osprey builds constantly in trees, but in this country it seldom does so, probably from the want of trees suitable for the purpose. I have been told, how- 
ever, that a nest is still to be seen on a tree in one of the large pine-woods in Strathspey.

A very curious circumstance happened on the same island, which strongly indicated the habits of red deer during the season when their horns are soft and liable to injury. The island, which is scarcely a rifle-shot in length, and less in breadth, is very rough, and cut up like an old peat moss, but covered with very high heather and coarse grass, in which the wild goose forms her nest. While I was looking about quietly in the broken clefts and ground for these nests, a large stag suddenly rose at my very feet out of a deep hollow-that is, deep comparatively speaking, and just sufficiently so for a stag to lie in. The wind was high, and he either had not heard me or he remained quiet in hopes that I should pass without perceiving him; at any rate he did not move till I nearly stepped upon him. He then rose, and in two springs was in the water and swimming strongly and bravely for the opposite mountain. A stag swims with very great speed and ease : in a short time he reached the shore, which was a good halfmile from the island, and having shaken himself, I saw him through my glass take a long look back, and then he trotted slowly up the shoulder of the hill. In my numerous deer-stalking excursions I 
certainly never was so near to an unwounded deer; he had evidently been living in solitary security for some time on the island, and feeding on the coarse grass and plants. He probably had been there ever since he had cast his horns, as the new ones were about five or six inches in length.

While on this island, too, another interesting incident took place. We heard the baying of a hound on the shore. At first I imagined that some fox-hunter's dog had strayed away in pursuit of and was still rumning a fox or deer; but on looking with my glass, I saw a fine fox-hound sitting on a point of land which reached into the lake, and howling in a manner which plainly showed he had lost his master; and having heard me fire at a crow, he imagined that I was the person he was in search of. After howling for a minute or two, till the hills around echoed with his deep voice, the gallant dog swam into the loch and made for an island on which I had fired at a gray crow. I saw him land and, with nose to the ground, take up our track; but after a little hesitation he found that the scent was not that of his master, nor of any one he knew, so plunging into the loch again he made for the mainland, and having reached it after a stout battle with the waves (the wind then being high), he continued his search round the shore of the lake, 
taking, however, no further notice of us, although I fired one or two more shots within his hearing. The instinct and reasoning of the dog struck me as very great in his manner of trying if we belonged to the party who had been up to the high ground before daybreak in pursuit of a lamb-killing fox; for we afterwards heard that the fox-hunter of the district had been following his avocation on the heights of Ben Cleebrick that morning, and that some of his dogs had strayed away from him in pursuit, probably, of a deer, though he owned only to their having followed a fox.

As we were rowing back to the point where we launched the boat, we suddenly came upon no less than six of those beautiful birds, the black-throated diver. We pursued them immediately, and drove them up into a small bay of the lake: there after much trouble we managed to shoot one, the rest escaping by diving under the boat or round it, and getting off into the wide part of the loch. None of them attempted to take flight, although so hard pressed and hemmed up into a corner of the lake. When one was separated from the rest he generally began to croak in the voice peculiar to these birds. In consequence of their swimming so low in the water and their great strength, it is very difficult to shoot them, particularly as when they 
are once alarmed they dive so suddenly that they are frequently too quick even for a percussion gun. When alone this bird takes wing readily enough, and flies off to some neighbouring lake with a quick and lofty flight.

We found our luggage safe under the care of the faithful dog, who had never left his charge, and before dark we arrived at the inn of Aultnaharrow, which is situated near one of the finest lakes in the country, Loch Naver. Like all the inns in Sutherland which are under the efficient and liberal management of the Duke's factors, Aultnaharrow is clean and comfortable.

The following day, leaving my friend to fish in Loch Naver, I drove off in the boat, accompanied by Dunbar and one of Lord Ellesmere's foresters who lives close to the inn, for a loch called Loch Laighal, or, as it is pronounced, Loch Loyal. This is another fine sheet of water several miles in length, with a few islands, the breeding-places of gray geese and numberless gulls. There were vast flocks of that magnificent bird the great black-backed gull (Larus marinus), and also of the lesser black-backed gull (Larus fuscus). The former is a most splendid and beautiful bird, with its pure black and white plumage, and a stretch of wing little less than that of the golden eagle. 
We had scarcely launched our boat on the water, leaving the forester on shore, as our tiny craft scarcely held three people comfortably, when a squall of wind came on, blowing down the side of Ben Loyal in a perfect hurricane right from the shore which we had just left. Short as the distance was, we could not row back against it, and had nothing left for it but to go before the wind right across the large loch, fully a mile and a half in width at that part. At the same time, owing to the lowness of the stern, our only chance of safety was to keep the head of the boat to windward, a matter of no small difficulty, as the wind blew in the most violent gusts and increased every moment. The slightest turn of the boat, which would bring her at all broadside to the wind, must have instantly swamped her, and with this pleasant prospect before us we went with fearful speed across the loch. The only thing I dreaded was that anything should give way about the oars, or the pins that they worked upon, as nothing could then have saved us. However, Diis aliter visum, and we landed safely, but wet enough, on the opposite shore, and right glad we both were when we looked back at the water, which was perfectly white with foam, to feel our feet once more on terra firma. I mention this incident as a warning 
to any person who may fish or sail on any of these fresh-water lakes surrounded by mountains, to beware of sudden squalls of this kind; for in this instance nothing but a strong arm and good rowing saved us from certain drowning, which would nevertheless have been our fate had the least bolt or fastening given way about the oars, for once broaching to must have swamped us. The wind soon fell, the day became hot, and the beautiful lake with its green banks was again as smooth as glass. Few of the gulls had laid, but we found some more eggs of the Gray lag goose. One nest was in a very peculiar situation for a wild-goose, being in the midst of and overhung by a thicket of small birch-trees. The otter seems to live in undisturbed security in the islands on all these lakes, as the heather, etc., is full of their roads and marks.

On the stones near the lake I picked up a large adder. As I held her up by her throat it was curious to see the fierce expression of rage the creature put on, and also how its long teeth projected, as if eager to be fastened in my hand, while a drop of bright yellow liquid oozed out at the points of each of its venomous fangs. I knew that this was the poison, but had no idea that these reptiles could produce so large a quantity at once. 
Loch Laighal, Loch Maddie, and Loch Naver all abound in the finest trout, and contain also plenty of the Salmo ferox or great lake trout, which is caught only by trolling, or by lines baited with small fish. In Loch Naver there are plenty of salmon: I am told that they rise freely and well when the wind is from the south-east, but seldom when it blows from any other quarter.

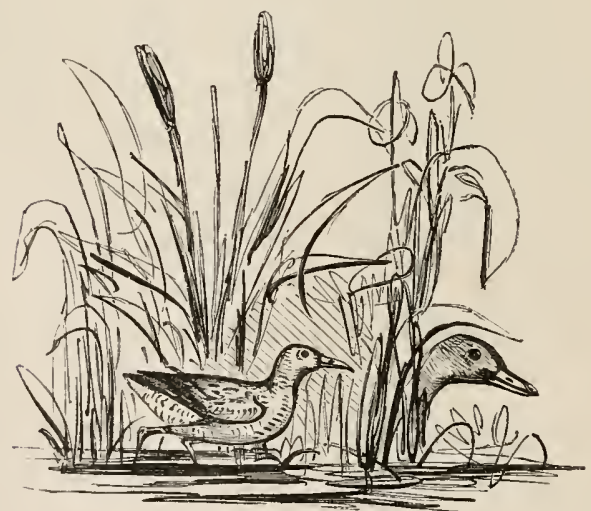




\section{CHAPTER IV.}

Return to Sutherland - Travelling from Edinburgh - Skye Terrier; peculiarities of - Lairg-Loch Shin-River Shin - Reserve of the English - Mrr. Young's experiments respecting Salmon; Aneclotes of Salmon; Manner of Spawning; Food of Salmon-Drive to AultnaharrowCurlews, etc.-Loch Naver-Phalaropes-Widgeon-Greenshank, etc.

June 9th.-Havixg been called suddenly to England in the midst of my rambles in Sutherlandshire in May, I did not find myself again in that county till the 9th of June. Travelling (that is, the mere act of passing along the road) takes up very little of your time nowadays. You go from London to Edinburgh in about thirteen hours, and a good steamer takes the traveller from Granton Pier to Invergordon in Ross-shire quickly and comfortably enough; that is, I left Granton at 6 A.M. on the 6 th, and landed at Invergordon early in the evening of the 7 th, accompanied only by a Skye terrier, who from his earliest childhood, or rather puppyhood, has always managed to stick closely to me. In wild-fowl shooting, when no dog is required save a quiet retriever, Fred (so was he christened by some of my children) is always allowed to accompany me, 
as from his quiet discretion he is never in the way. In roe-shooting also he is allowed to remain at my feet while I am waiting in a pass. At the same time, if permitted to hunt, no kind of animal, running or flying, quadruped or biped, comes amiss to him, and he is equally at home in any ground, rock, or loch. There is a kind of quiet, discretionary courage that some of these rough terriers have which is very amusing — nothing seems to put them out, and Fred is as much at home in a crowded railway station or London street as he is in a furzecover. He rather annoys me sometimes when travelling, for as soon as he has seen me safely housed in an hotel, he is very apt to wander off in search of adventures and acquaintance of his own through the town, wherever it is ; and although it may be a new place to him, he invariably finds his way back to my room for the time being, regardless of all obstacles in the form of waiters, chambermaids, etc. I used to be afraid of losing him, but after some experience of his ways, I find that I may safely leave him to his own devices; for having once or twice despatched ostlers and boys in all directions to search for him, I perceived that he always came back alone, looking rather ashamed of himself, and not venturing to make himself very prominent in the room till he had examined the expression of my 
face from under a chair or sofa, for dogs are great physiognomists. Then, on seeing that I am generally too pleased at his return to be angry at his absence, he comes out of his place of refuge wriggling his long rough body about in all sorts of coaxing but meouth attitudes, and at last, putting his honest rough face in my hand or on my knee, he finds that peace is declared, and he waits patiently till I take hat in hand again; for once having explored the streets, he seems to take no further interest in the place.

There is no end or limit to the quaint conceits of some terriers of this kind, when they live in constant intercourse with their masters. Fred's great attachment to my children, too, makes him a universal favourite in the house, and he walks about with them amongst their pet animals, apparently taking as much interest in them as the children do themselves. I must say, however, that he requires a formal introduction to any new living acquisition of this kind; but once introduced to them, they are safe from his strong white teeth for ever.

These terriers are excellent swimmers, and are apparently as much at their ease in the water as on land. Fred is as web-footed as an otter. Some dogs dislike accompanying one to the river side only to look on. Indeed, one retriever which I had be- 
came so bored and ennuyé with this work, that at last I had only to show him my fishing-rod to induce him immediately to retire to some hidingplace rather than be asked to accompany me. Another retriever, on the contrary, always took the most lively interest in my fishing, watching the fly and getting into a state of great excitement whenever I hooked a fish: indeed, if allowed to do so, he would go in and land the fish, taking it carefully and delicately by the back in his teeth; but as he often got entangled in the line and did mischief, I was obliged to stop this. A great treat, however, to this dog was to put some living sea-trout into any shallow pool, where he could catch them and bring them one by one to whoever carried the fishing-basket.

I have no doubt that many wild animals, such as the fox, wild-cat, polecat, etc., catch numbers of fish during their nocturnal wanderings. Their tracks about the water's edge have frequently convinced me of this: the fish, too, being apt to take to the shallows at night, are easier caught than in the daytime.

To return, however, to Sutherlandshire. On the 7 th of June I arrived at the good town of Tain, and on the 9 th was at Lairg Inn. An excellent place of rest, too, is the inn at Lairg, and the situa- 
tion beautiful beyond description - at any rate it is so on a fine day; but situated as it is at the end of Loch Shin, a Highland lake about eighteen miles in length, the prospect from the inn windows must be very different on a wild autumn day, with wind and sleet driving up from the west, from what it was on the fine June evening on which I arrived. The view combines the most happy mixture of mountain, water, and green herbage, dotted with fine old birch-trees : a few picturesque buildings, too, which are seen from the inn, add to the happy and riant expression of the scene.

The Shin river, which runs out of the lake near the inn, is a fine and picturesque stream, charming to the eye of both painter and fisherman. The Shin salmon are of a large size and very plentiful. I stopped for half an hour or so at the falls, two or three miles from the lake, and saw a great number of salmon, and even trout, leaping; some of them succeeded in passing up, others fell back into the pool below, in consequence of not having leaped with sufficient strength, or from having miscalculated the distance and angle at which to take the leap. All the scenery about the falls of the Shin is very beautiful: the steep and lofty hill which comes down to the water's edge is covered with wood, and, at this time of the year, was alive

VOL. I. 
with singing birds of all kinds; whilst the coo of the wood-pigeon, and the shrill cry of the kestrel as she hovered with quivering wings over our heads, combined to please the eye and ear.

We were rather amused with the truly English determination which was shown by a gentleman (who, like ourselves, was admiring the falls) not to enter into conversation, or indeed to admit that he was aware of our presence. Perched on the extreme point of rock overlooking the falls, for above half an hour he turned his back most resolutely towards us, as we sat immediately behind him.

It is part of the nature of Englishmen to look upon all strangers as intruders, if not as enemies; and yet many a pleasant acquaintance and friendship have I formed without any formal introduction, being, I am happy to say, un-English enough not to be afraid of committing myself or of losing caste by addressing a stranger. Throughout life I always find that civility is met by civility, wherever it may be bestowed. At the same time nothing is easier than to put a stop to impertinence should one meet witl it.

En route to Lairg I called on Mr. Young, who is manager of the Duke of Sutherland's fisheries in the county. He received me with great civility, and kindly gave me much curious and interesting 
information respecting the habits of salmon and trout, having studied their natural history, and having lived, as it were, amongst fish during his whole life. Mr. Young has made such good use of the opportunities which his position has afforded him, that he has thrown considerable light on the history of the inhabitants of an element in which we cannot follow them. His patience in trying experiments with the spawn and young of the salmon has enabled him to explain many parts of their history which had hitherto been obscure, or at best but imperfectly understood. The encouragement, too, which he has always met with from the Duke, has still further enabled him to bring a naturally acute and inquiring mind to bear on the point in question. For some years he managed (by forming artificial spawning-beds or ponds) to have the ova under his immediate observation from the hour of their being deposited to the time that in the shape of "smolts" (I think that is the local name) of four to six inches in length, the young salmon go down to their mysterious feeding nurseries in the depths of the ocean. Mr. Young kindly showed me numerous specimens preserved in spirits of wine of the gradual development and growth of the fish from its egg state, when it looks like a small pea, to its full maturity. 
Strange as it seems, it would certainly appear from his observations that a salmon may be kept for any length of time in a river without growing beyond the weight of two to four ounces, and he showed me specimens of salmon which, though of perfect form and condition, did not exceed that size; whereas, had they been allowed to reach the sea, they would at the same age have weighed from six to ten pounds each. The growth of salmon when in the sea is wonderful, it having been indisputably proved that a salmon has grown eleven pounds six ounces during the short period of five weeks and two days: the fish having been marked on its passage to the sea, was caught again in the same river when ascending, after an interval of that duration.

The destruction of salmon during their passage to and residence in the sea must be wonderful, and defies all calculation. Did all the fish which descend as fry return as salmon the rivers would not hold them. Their enemies are countless; every fish and every sea-fowl preys and fattens on them. At the mouths of rivers, and indeed at every shallow on their passage, thousands of gulls and other birds prey upon the fry, while trout and eels are feeding on them under water. As soon as they reach the sea, too, fish of all kinds are ready to devour them. 
Mr. Young told me also that his young family of salmon fry which he hatched and kept confined in ponds connected with the river always become perfectly tame, and the moment that he steps on the plank laid across the ponds for the purpose of feeding the fish from, they all flock round him ready to dart at the food he puts in. In some of the ponds he had put a number of small eels, which soon grew in size and became as tame and familiar as the young salmon. As the cold weather came on the eels all disappeared, and he supposed that they had managed to escape, led by their instinct to take refuge in some deeper pools. However, one fine spring day, when he had long ceased to think of his slimy pets, he happened to pass over one of the planks, when he was delighted to see them all issue out from under the stones asking for food, as if a day only, instead of many weeks, had passed since he last had fed them. Does not this most clearly prove that eels lie dormant during cold weather?

I asked Mr. Young if he could explain why at the mouths of rivers, when angling, one always catches such a variety of trout-a variety which does not exist at some distance from the sea, each and every stream having its own peculiar species. His opinion, founded on practical experiment and 
long experience, coincided much with mine founded on mere casual and unscientific observation, namely, that the sea trout and river trout sometimes breed with each other, thus forming a great variety of shade and colour. He also states that the female salmon will breed with a male trout, which he says has been clearly proved by close observation, in the following manner:-A pair of salmon, male and female, being seen forming their spawning-bed together, the male salmon was killed with a spear and taken out of the water. The female immediately dropped down the stream to the next pool, and after a certain interval returned with another male. He having shared the same fate as his predecessor, the female again went down to the pool, and brought up another male. The same process was gone on with of spearing the male, till the widowed fish, finding no more of her own kind remaining in the pool, returned at last accompanied by a large river trout, who assisted her in forming the spawning-bed, etc., with the same assiduity that he would have used had she been a trout instead of a salmon; the female appearing to be determined that her ova should not be left in the gravel without being fertilised by the male, thus taking the trout as a pis aller, and carrying out the proverb- “si on n'a pas ce qu'on aime, il faut aimer ce qu'on a." 
CII. IV.

The process of preparing the spawning-beds is curious. The two fish come up together to a convenient place, shallow and gravelly. Here they commence digging a trench across the stream, sometimes making it several inches deep. In this the female deposits her eggs or ova; and she having left the bed, the male takes her place, and deposits his spawn on the ova of the female. The difference may be perhaps easily exemplified by the soft and hard roe of a herring; the former being that of the male, and without this the hard roe or ova of the female fish would be barren. When the male has performed his share of the work, they both make a fresh trench immediately above the former one, thus covering up the spawn in the first trench with the gravel taken out of the second: the same process is repeated till the whole of their spawn is deposited, when the fish gradually work their way down to the salt water to recruit their lost strength and energy.

The spawn is thus left to be hatched in due time, but is sometimes destroyed by floods, which bury it too deep, or sweep it entirely away; at other times it is destroyed by want of water, a dry season reducing the river to so small a size as to leave the beds exposed to the air. The time required to hatch the eggs depends much on the state of the weather; 
in warm seasons they are hatched much quicker than in cold. The details I have here given are very imperfect; but perhaps they may induce those interested in the subject to read a little work published by Mr. Young, the result of his observations and experience for many years.

It is a common opinion that no food is ever found in the stomach of a salmon; but this is quite erroneous. On first entering the rivers they are often perfectly gorged with small eels; fry and even good-sized herring are constantly found in them; showing that the salmon is as voracious a fish as his cousin the trout. When in fresh water they do not seem to have the same voracity. That they do feed on small fish, etc., however, in lake and river, cannot be doubted, as we know that trolling with parr is as efficient a way of killing salmon in several waters as fly-fishing, though not so generally practised: nay, many a salmon dies an ignoble death from taking a worm.

This year I was fishing on a river in the north of Scotland, near a town where there was plenty of anglers, young and old, good and bad. There was one old piscator, who was most assiduous in his attention to the river, and whom I have seen for hours together at one small pool, changing his bait from fly to worm and from worm to fly, as he fancied 
the inclinations of the fish might be turned at the moment. One day we saw him in his usual position at the head of a rocky pool, and found that he had risen a salmon. After tempting the fish with every fly contained in an old bible, which served as a fishing-book, without success, he told us, as we greeted him in passing, that he would have the fish before dark: and sure enough, late in the evening, while taking a stroll up the river, we met the old gentleman coming home, and after a little coquetry on the subject, he produced the salmon, wrapped up in a snuffy pocket handkerchief and crammed into his trousers, where he carried it in order to avoid notoriety on the subject. Not having permission, I fancy, to kill salmon in the river, he had killed the fish with a worm late in the evening, after everything else had failed.

The first few miles of the drive from Lairg to Aultnaharrow we skirt the edge of Loch Shin, passing through a beautiful wood of birch, at this season (June) full of singing-birds, wood-pigeons, etc. Beyond this we pass for many miles through a desolate and dreary-looking range of hill ground - the more desolate-looking too from the ground being covered with a kind of coarse grass, instead of the rich brown red of the heather. The number of curlews and golden plovers is very great all 
along this grassy tract of country. The plovers are very tame, ruming along the road in front of the horse, and at last only flying a few yards to some higher hillock or stone, where they stop watching us till we pass. These birds have their nests rather high up on the hills : their eggs are peculiarly large and beautifully marked, the prevailing colour being a brown, shaded and spotted with darker markings of a brownish-green colour. It is very difficult, however, to describe the eggs of many of these birds, no two of them being exactly alike. The curlews are far more shy and wary, and as long as we are within sight they keep up a loud unceasing cry of alarm, wheeling round and round, but generally at a tolerably respectful distance. I saw some young curlews on the ground, and got out to examine them ; they are curious, long-legged, topheavy, little fellows, and when pursued seemed to trip themselves up in their hurry, and to tumble head foremost into every hole in their way. The bill of the young bird is as short as that of a golden plover. When I held it in my hand to examine the curious plumage, or rather down, which covered it, the little bird looked up at me with its great dark prominent eye with such an expression of confidence and curiosity, that had I been the most determined collector of specimens of birds, I could 
not have refrained from putting him carefully down on the ground again : when I did so he ran up to the top of a little grassy hillock, and looked round for his screaming parents, who, at a safe distance, were wheeling with a most wonderful outcry round the head of my terrier.

One cannot understand why a curlew's bill should be curved in the curious manner in which it is. The end of the bill is, like that of a woodcock, furnished with a set of delicate nerves to enable it to feel its food under the ground. In those parts of the country where curlews are numerous, the moist turnip fields are generally bored all over by them. I tried for trout in Loch Naver (close to the inn at Aultnaharrow), and caught some fine and excellent fish for our supper.

In the swampy ground near the west end of the lake a vast number of birds seem to breed. Snipes, curlews, redshanks, plovers, etc. etc., all keep up a constant cry of alarm on any intrusion into their dominion. While I was fishing Mr. Dunbar called my attention to two beautiful little birds near the edge of the water, which he pronounced to be the red-necked phalarope. Not having any specimens in his collection, he went to the inn for a gun, while I sat down to watch them. The red-necked phalarope is certainly the most beautiful little wader of 
my acquaintance. There were a pair of them, male and female, feeding near the loch, in a little pool which was covered with weeds of different kinds. Nothing could be more graceful than the movements of these two little birds as they swam about in search of insects, etc. Sometimes they ran lightly on the broad leaves of the water-lily, which served them for a raft and entirely kept them out of the water. Though not exactly web-footed, the phalarope swims with the greatest ease. The attachment of these two birds to each other seemed very great: whenever in their search for food they wandered so far apart as to be hidden by the intervening weeds, the male bird stopped feeding suddenly, and, looking round, uttered a low and musical call of inquiry, which was immediately answered by the female in a different note, but perfectly expressive of her answer, which one might suppose to be to the purport that she was at hand and quite safe: on hearing her the male immediately recommenced feeding, but at the same time making his way towards her; she also flew to meet him : they then joined company for a moment or two, and after a few little notes of endearment, turned off again in different directions. This scene was repeated a dozen times while I was watching them. They seemed to have not the slightest fear of me, for frequently they 
came within a yard of where I was sitting, and, after looking up, they continued catching the small water-insects, etc., on the weeds without minding my presence in the least.

After having apparently exhausted the food in one pool, on a signal from the male they suddenly both took wing, and flew away to a fresh feedingplace two or three hundred yards off, where we afterwards found them. Though we could not discover their nest, I have no doubt that they had eggs very near the spot where we saw them. Indeed, on dissecting the female we found two eggs in her, nearly full-sized, so that probably she had already deposited the other two, which would have made her number complete. I find no account of this bird breeding on the mainland of Scotland.

A great many widgeon breed about Loch Naver. I saw several drakes sitting on the points of grass running out into the lake, shining brightly in their beautiful and variegated summer dress. I also came upon an old duck-widgeon, who kept fluttering round my feet. On looking closely I found about seven young widgeon two or three days old, very like wild-ducks of the same age, but having, instead of the green colour of the young mallard, a kind of reddish brown tinge over the whole of their down. They soon scuttled away into the 
lake, and we presently saw them swimming far out with the old bird. The number of young redshanks, peewits, etc., seemed very great. The terrier found them everywhere. The redshank has a merry and not unmusical note as he flies round and round with great rapidity on his nest being approached. I saw no greenshanks about Loch Naver, but plenty of them about the smaller and more lonely rushy lakes on the hills. The note of the greenshank is musical, and not quite so shrill as that of the redshank. Its flight, too, is different, making longer strokes with the wing; it darts with sudden jerks through the air, somewhat in the manner of a dragon-fly; sometimes hovering, and then darting downwards with great quickness. The nest of the greenshank is particularly difficult to find. I never found one myself, and have only once heard of its having been discovered. There is a peculiarity about the egg which, though difficult to describe, immediately strikes the observer, if he is at all learned in birds' eggs. The prevailing colour is olive-green. The shell seems of a fine texture, and the spots are small, but numerous.

A forester brought me four eggs, which he said were those of the jack snipe. Though I have every reason for thinking that he would not wilfully have deceived me, I suspect that he was mis- 
taken in the bird, and that the action of the hen snipe when disturbed from her nest being unlike her usual flight, made him believe her to be the jack snipe instead of the common one. The eggs were certainly small for a snipe, but not smaller than I have sometimes seen them. I have never read any account of the jack snipe breeding in Scotland that I considered well authenticated. There is every probability that a few birds, unequal to the long flight of their migration, may remain in this country during the summer. But notwithstanding the eager search made for the nest by egg collectors, it has never yet been found in Scotland. I heard that the jack snipe had been seen breeding near Tongue, but the gamekeeper there says that this is not the case, and that probably the dunlin was mistaken for that bird.

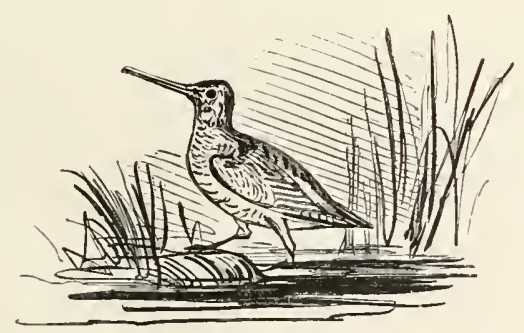




\section{CHAPTER Y.}

Length of Day - Sedge Warbler-Different Birds near Loch Naver-Ben Cleebrick-Rain-Loch Maddie-Frost-Ben Laighal-Foxes-Sheep Killing - Catching Wild-ducks Peregrine Falcon ; Manner of catching their Young-Golden Eagles-Tongue-Fine Scenery of Bay of Tongue and Islands-Wild-cat-Seals.

THE nights at this season are most enjoyable; in fact, there is no darkness. I went out of the inn at midnight, and was much amused at hearing the different cries of the birds. Close to the door is a small enclosed clump of larch, where the grass and weeds are very high and rank. In this little patch it seems that a sedge warbler had made her nest. All day long had the male bird been singing to his mate, and now at midnight he was still uttering unceasingly his merry note; I never met with so indefatigable a songster; night or day he seemed never to weary.

Towards the loch a constant tumult was kept up amongst the waders and water-fowl. High in the air was heard the common snipe, earning his Gaelic name of "air goat" by his incessant bleating cry ; while redshanks, curlews, golden plovers, and peewits, all seemed to be as lively as if it had been 
noon instead of midnight; occasionally, too, both widgeon and teal were heard to whistle each after its own peculiar fashion; and the quack of the common mallard was also constant. Now and then a note expressive of alarm was uttered by some bird, and immediately a dead silence was kept by the whole community for a few moments; but this was soon succeeded by a greater noise than ever, particularly amongst the peewits, which seemed by their cries to be darting about the head of some intruder or enemy. Probably on these occasions a fox, wild-cat, or owl had made his appearance amongst them in search of tender food for his own young ravening brood.

Though I had to rise very early, I betook myself to bed with great regret, and left the window open in order to hear the serenade of the sedge warbler to the last moment of being awake.

Ben Cleebrick, the highest hill (or nearly so) in Sutherland, is immediately in front of the inn; and the forester, after looking at me from head to foot, pronounced his dictum that he thought I should get to the top in two hours or so; at any rate, that he could do it in that time. Notwithstanding the threatening look of the mist on its summit, I started, hoping to see some ptarmigan nests amongst the loose stones near the top. Dunbar warned VOL. I. 
me that we should not succeed in reaching the summit, owing to the state of the weather; and he was correct; for, although there was an occasional clearing away of the clouds, when we were about half-way up there commenced such a determined and heavy torrent of rain that we had to give in; the whole mountain, too, was enveloped in a cloud like a wet blanket, impenetrable to the sight. For a long time we sat down under my plaid, which kept us tolerably dry (Dunbar, myself, and the $\operatorname{dog}$ ); with nothing else to enliven us except watching the curious antics of two ravens on a great lump of rock in front of us. At last, in despair, we made our way home as quickly as we could, splashing through the rain-water which had converted the whole hill-side into pools. Near the loch-side, amongst the birch-trees, I saw a great many red-poles and other small birds.

From Aultnaharrow we drove again to Loch Maddie, where I caught some fine trout. We saw a few Gray lag geese, and found the gray crows again tenanting the nests which we had attacked three or four weeks ago. Of course I smashed every egg and killed every crow that came within my reach.

On the 10th of June the frost was so severe in Strath Naver that it cut down all the potatoes 
to the ground, and even the ferns and some other wild plants near the waterside were entirely -blackened. A hard white frost at this season is always supposed to be followed by heavy rain, and the saying was this time quite correct.

On our road to Tongue the following day I stopped for an hour or two about Loch Laighal, one of the most beautiful of the lakes in Sutherland. Ben Laighal is a fine and picturesque mountain, and of great extent. We learned at a shepherd's house that the fox-hunter of that district had been up on the mountain since three o'clock in pursuit of some foxes who had established themselves in the rocky corries near the summit, and had commenced killing the old sheep. It is not the general custom of foxes to destroy the old and full-grown sheep where lambs are plentiful; but a colony or pair of foxes having once commenced this habit, the mischief and havoc which they commit are beyond calculation, more particularly as they seldom tear or eat much of so large an animal, but feed on the blood. According to the accounts of the shepherds the foxes of Ben Laighal are very prone to this kind of prey, and kill the old sheep in preference to lambs or game.

The foxes in the Highland districts must frequently be put to many shifts for their living, and 
no doubt become proportionally cunning. To keep himself in the fine and sleek condition in which a fox always is, many a trick and ruse de guerre of surpassing cleverness must be practised. The stories of their manœuvres to catch animals are endless; and, though many of them would be amusing enough, I do not like quoting as facts incidents of this kind, the authenticity of which I cannot vouch for, however much I may believe them to be true, and I must confess to being very credulous on this point. I have been assured by a person, not given at all to exaggerate nor easily deceived, that he once witnessed the following trick: Very early one morning he saw a fox eyeing most wistfully a number of wild-ducks feeding in the rushy end of a Highland lake. After due consideration, the fox, going to windward of the ducks, put afloat in the loch several bunches of dead rushes or grass, which floated down amongst the ducks without causing the least alarm. After watching the effects of his preliminary fleet for a short time, the fox, taking a good-sized mouthful of grass in his jaws, launched himself into the water as quietly as possible, having nothing but the tips of his ears and nose above water. In this way he drifted down amongst the ducks, and made booty of a fine mallard. Though this story seems extraordinary, it 
must be remembered that the fox manages to capture wild-ducks, wood-pigeons, hares, and number- less other animals, sufficient to keep himself and family; and it is self-evident that in doing so he luust practise many a trick and mancuvre that would seem most improbable if related, and quite beyond the instinct of animals. I have seen one in confinement lay out part of his food just within reacl of his chain, in order to attract the tame ducks and chickens about the yard, and then, having concealed himself in his kennel, wait in an attitude ready to spring out till some duck or fowl came to his bait, which he immediately pounced upon. Those, too, who have trapped foxes can tell of the extreme cunning and sagacity displayed by them in avoiding danger. In fact, altogether, a fox in a state of nature is as interesting an animal as he is beautiful, and nothing can exceed the grace and agility of his movements when he is hunting or playing unobserved, as he fancies, by his enemy man. It has happened to me frequently to have opportunities of watching a fox, and I have always been unwilling to put a stop to my amusement by shooting him, which, in a country where hounds cannot be kept, one feels bound to do, as a punishment for the endless mischief which he commits. On the east or north-east side of Loch Laighal 
there is a very beautiful hill covered with wood to a considerable height, and surmounted by a curiously-formed steep cliff-the very place for an eagle's nest: I was told that a nest had been destroyed there last year.

The whole view of Ben Laighal is magnificent, and in driving round it we had the advantage of seeing it on every side. Towards the loch the mountain slopes down, covered with bright green herbage; but to the north and west nothing can surpass the savage grandeur of its rocky precipices. Viewed from Tongue, Ben Laighal is, I think, the most magnificent-looking mountain in Sutherlandshire. Our attention was attracted by the cries of the peregrine falcon, and we saw the two birds flying about a high rock. Having hailed a shepherd's boy, we learned where the nest was, and under his guidance climbed up the mountainand a good steep climb it was - till we got within a few yards of the nest; so near, indeed, did we reach, that with two joints of my fishing-rod I could just touch the young birds, who were sitting eyeing us boldly and fearlessly on a ledge of rock where the nest was placed. When, however, we attempted to push them out of the nest, they retired farther in, where they were in tolerable security. All the time we were there the old 
birds flew screaming over our heads. I did not think of a plan that is adopted sometimes to capture young peregrine falcons when the nest cannot be reached without danger. It is very simple, and succeeds with all the courageous kinds of hawks. A person having reached the top of the rock immediately above the nest, ties a rough blue bomnet, or some similar substance, to a bundle of heather the size of a man's head; then dropping this attached to a rope upon the nest, the young falcons, instead of being frightened, immediately attack it, and, sticking their talons into the cap, hold on courageously and determinedly till they are dragged up to the top of the cliff. Even then it is sometimes necessary to cut the cap to pieces before they will relinquish their hold. In this way the young birds are captured without risk to the capturer or injury to themselves. Indeed, on the present occasion I was not very anxious to get them, as they would probably only have been destroyed in travelling.

Between Loch Laighal and Tongue, on driving lound the corner of a rock, we suddenly came upon two golden eagles who were hunting close to the road. They were nearly within shot of us; so, leaving the horse and carriage to take care of themselves, we jumped out, gun in hand, to try to get 
shots at them. Two or three times the birds swooped down, and one of them carried off some bird, probably a grouse, taking it far away round the cliffs of Ben Laighal. The other eagle then made a sudden swoop down to the ground, within a hundred yards of us, but just behind a small hillock; we ran to the place, confident of getting the bird, but arrived just in time to see the eagle carrying off its prey, whatever it was, in the same direction as that taken by its mate, in all probability straight to the nest.

Reaching the brow of a hill, we came in full view of the fine plantations and bay of Tongue. Beautiful and refreshing to the eye were the woods and cultivated fields of Tongue, bursting into view suddenly as they did, after some days' travelling through the rugged wilds of the interior of Sutherland. The beautiful bay was as smooth as glass, the timber growing to the water's edge; and the whole scene was made still more striking by the abrupt and precipitous outline of the headlands both of the mainland and the islands at the mouth of the Kyle. It is worth a journey of many miles to see the Kyle of Tongue alone.

Tongue House, formerly the residence of Lord Reay, the then proprietor of a magnificent range of mountain property, is one of the most beautiful places of the sort that I ever saw. The house itself 
is irregular, but picturesque; and the gardens, overlooking the sea, are warm, sheltered, and most enjoyable in every respect. The fruit, flowers, and vegetables were growing with as much luxuriance, and were nearly as forward as I should have expected to have seen had they been situated in the southem instead of the northern extremity of the island; while the fine avenues and groves of elm and other trees would do credit to any place in England. All this, combined with the wild outline of rocks and cliffs which nearly surround the bay, and the magnificent precipices of Ben Laighal-all this combined, I say, formed a coup d'œil, which, though it may be equalled, can scarcely be surpassed in any country. I understood from Mr. Horsburgh, the Duke of Sutherland's factor in this district, that his Grace contemplates making a harbour within the Kyle of Tongue.

The keeper pointed out to me from near the inn the sites of two eagles' nests in the rocks of Ben Laighal, and a more appropriate or fitting locale for eyries I never saw.

At the entrance to the bay are some islands-one named Roan Island, or the Seal Island; and the others are called the Rabbit Islands, from being tenanted by numbers of these animals. The rabbits, lowever, must there be of little use, excepting as 
food to birds of prey. In the winter the eagles and lawks feed greatly upon them. The eider-ducks also breed on these islands, and are so tame when nesting that they allow themselves to be lifted off their nest, and the down of which it is formed to be taken away without deserting it. I saw a few eiderducks swimming about in the bay, amongst numerous cormorants and other birds. The rocks along the coast are inhabited by a great number of wildcats, otters, etc., who live here in tolerable peace, as the game is not much looked after excepting in particular localities. Indeed, the ground near the coast here is not well adapted for grouse. The keeper showed me at his house an immense cat, which he said was bred between a tame and a wild cat; and though such an occurrence is very rare, I am sure that he was correct in this instance. The animal showed certain peculiarities of his wild father's race, in the size and shape of his head, the shortness and roughness of his tail; and in other points had a likeness to the wild-cat, which, though difficult to explain, was unmistakable. I have seen this resemblance to both parents in mules of different kinds, such as a mule between blackcock and pheasant, or pheasant and common fowl, in all which birds something catches an accustomed eye which immediately points out what the parents 
were. The cat, too, belonging to Ross, the keeper at Tongue, had peculiar wildness and antipathy to strangers, not suffering himself to be caressed, or indeed scarcely to be looked at, by any one excepting the keeper's wife, for whom the animal showed great attachment. When I entered the house he bolted out, and it was with difficulty that Mrs. Ross caught him; and when she brought him in again in her arms, the animal showed the greatest fear of and animosity to me, and was constantly endeavouring to escape.

It was delightful to hear in the plantations at Tongue the coo of the wood-pigeon and the songs of thrush, siskin, etc. etc. The trees seemed to be full of birds, most of which, to reach these woods, must have wandered over many miles of ground very uncongenial to their habits and tastes. Indeed it is difficult to understand how many of the birds, such as the golden-crested wren, the little blue titmouse, etc., could ever have found their way here. The landrails too seemed to be numberless; in every patch of corn they were calling and answering each other in such quantities, that it was impossible to tell how many were croaking at once. I also heard two or three goatsuckers (Caprimulgus) making their whirring noise about the stone walls and belts of plantations. All 
CH. V.

night the sedge-warbler was cheering his mate with his sweet and constant song.

I saw some seals playing the most extraordinary gambols in the smooth water. The sea was as calm as possible, and like a mirror everywhere, excepting where these animals were swimming after each other in a circle, so rapidly that their track resembled a complete whirlpool. Occasionally they lifted themselves perpendicularly up in the water, showing half their bodies, and looking as like the representation of a mermaid as possible.

I should have liked to prolong my stay had it been in my power to do so, as there is much to interest the visitor, both in the varied and magnificent scenery of land and water, and also in the numerous wild animals, common enough here, but rare in the more southern parts of the country.

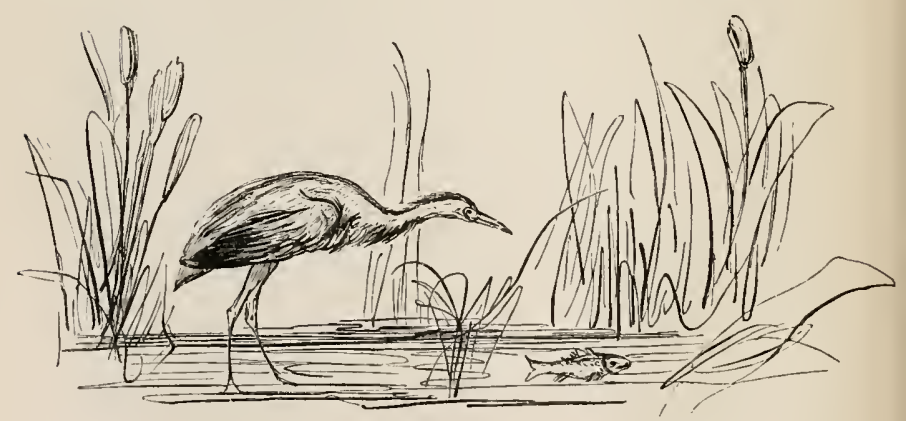





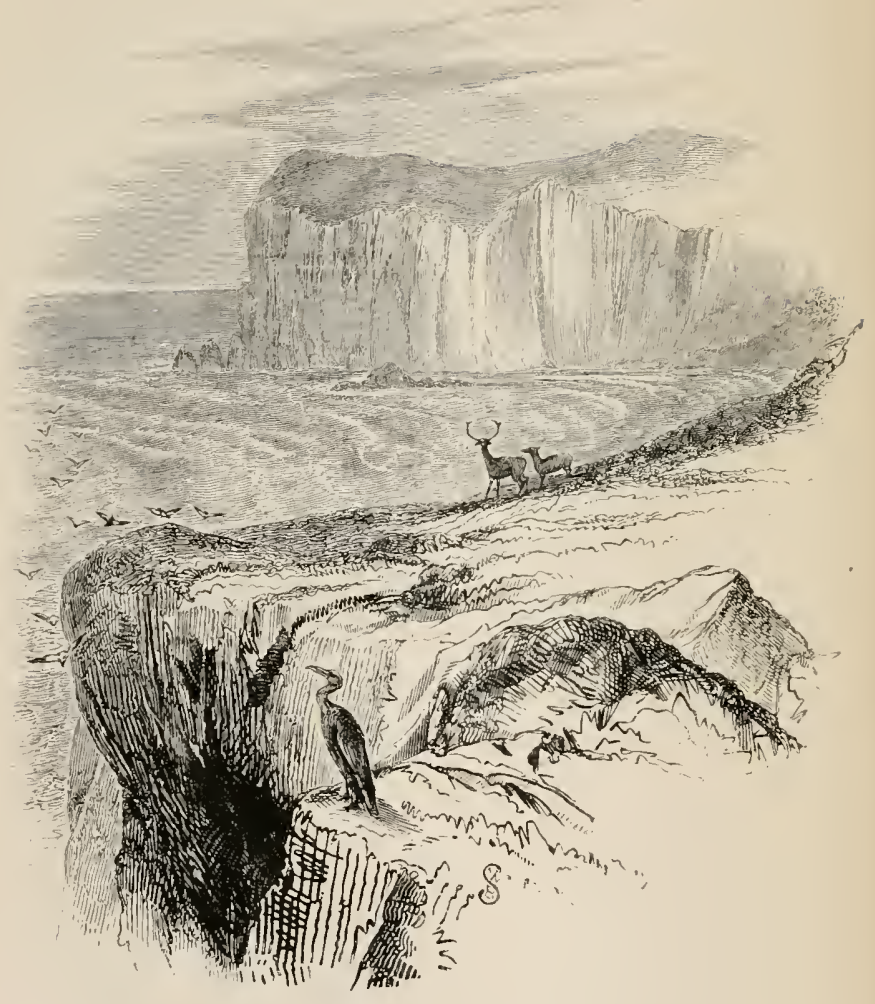

View of Whiten Head.

Vol. i. p. 77.] 


\section{CHAPTER VI.}

Ferry from Tongue-Difficulties of our Start-Seals-Shepherds, etc. -Emigration-Heilam Inn-Storm-River Hope -Drive to Durness-Cave-Rock Pigeons-Inn at Rhiconnich-Search for Osprey's Nest-Swimming to NestLoch of the Eagle Fisher-Stalking the Osprey-Row up the Bay-Loss of Fishing Line-Scowrie-Island of Handa -Innumerable Birds, etc.

OuR start from Tongue for Durness was amusing, though not without difficulty. We had to cross a ferry immediately below the inn; but on going to the ferry-house and raising the flag that signified the want of a large ferry-boat (the boats being on the opposite side of the bay), we after some delay were answered by the arrival of a small sailingboat, far too narrow to take over either horse or carriage. On making inquiry of the ferryman, he told us that the large boat was at present out of the water and under repair, but that if we could wait ten days or a fortnight it might be ready. This did not sound promising; but I settled the difficulty by sending the horse to a point, from which a boy was to bring him across a part of the sands fordable at low water. We then took the boat off the wheels, which we managed to stow 
away in the small ferry-boat, and taking our own boat in tow, we sailed across with a good breeze, which carried us well over the bay. In one part the current of the ebbing tide is very strong.

While waiting for the horse's arrival I amused myself by watching through my glass the singular and awkward-looking antics and gambols of a large lerd of seals, who were playing and resting upon a sandbank in the middle of the bay. It is curious to see with what activity these unwieldy-looking fellows move themselves about on the sand, ill adapted as they appear for locomotion on the land. The cry of the seal is wild and mournful, difficult to describe, but something between the mew of a cat and the howl of a dog; a most unpleasant sound it is, though it sometimes harmonises sufficiently well with the wild scenery surrounding them.

Some thirty miles out at sea opposite this part of the coast is an island, or range of rocks. Exposed to all the violence of the breakers of the Northern Sea, it is difficult to land on; but once or twice a year a crew of fishermen go off to it in a strong boat, and usually manage to get about a hundred seals, the oil and skins of which repay them well for their labour.

Blue rock pigeons live in all the caves on this coast, and are to be seen flitting to and fro from morning to night. 
For some distance after crossing the Tongue ferry the road is dreary and bleak, passing over a brown and wet tract of mossy ground, and for several miles we continued ascending. The wind and rain were incessant and very heavy. Having surmounted the highest ridge, we descended the hill to the Hope river, which is crossed by what is called a chain-boat; that is, we drive upon a wooden platform without taking the horse out of the carriage. The platform then, with all upon it, is hauled across the river by means of a chain and windlass. The glen through which the river Hope runs is very beautifully shut in by its wooded banks; and the gray mountains offering a new point of interest at every turn of the road, give never-ceasing pleasure and excitement. Here we continually saw eagles and other rare birds. A shepherd told us that the lambs were killed every day by eagles; but he seemed to know little, and to care less, about the breeding-place of the birds. It is nearly impossible to get a direct or truthlike answer from many of the Highlanders; for though intelligent enough, they seem to have a kind of suspicious dislike to giving information.

One thing particularly struck me in this part of the country. Depending on the Duke of Sutherland's well-known kindness and liberality, the lower 
class of inhabitants take but little trouble towards earning their own livelihood. At whatever hour of the day you go into a cottage you find the whole family idling at home over the peat-fire. The lusband appears never to employ himself in any way beyond smoking, taking snuff, or chewing tobacco; the women doing the same, or at the utmost watching the boiling of a pot of potatoes ; while the children are nine times out of ten crawling listlessly about or playing with the ashes of the fire.

The Duke, having tried every plan that philanthropy and reason could suggest, has now succeeded in opening their eyes to the advantage of emigrating, and at a great expense sends numbers yearly to Canada, where these very people, who at home, in spite of every effort and encouragement, drag on a life useless to themselves and burthensome to others, when once settled in their new country, put their shoulder to the wheel, and rapidly become most independent and comfortable ; and instead of seeing their children grow up in the midst of selfimposed squalid misery, they see them become daily more prosperous and thriving. Certainly, in this rocky and sterile part of the country, it is difficult for a cottager to advance himself. The soil is not adapted for a numerous population; there is nothing to feed mankind on : all or the greatest part of the 
necessary grain must be imported from the low land; and the low-land farmers, finding a better price and better customers elsewhere,naturally send their produce to the best market. This mountainous country is only fit for sheep, and sheep-farming is by far the best use to put it to. The bays are certainly full of fish; but it seems nearly impossible to make good fishermen of hill-men, often as it has been tried. The north-west Highlanders, having found out from their friends the great advantages derived from emigration, are now anxious to take advantage of the Duke's liberal system of sending them out.

To continue our journey. We were obliged at last to make for a small inn called Heilam, on the shore of Loch Erriboll; and glad enough were we to get there, for it blew a perfect gale, and the rain was unceasing. Though the outside of the house looked unpromising, we found the interior clean enough, the people respectable, and plenty of fresh herrings and new-laid eggs. So, the storm not abating, we determined to take up our quarters there for the night.

Loch Erriboll is an excellent harbour of refuge during gales from the north and north-east. The anchorage is good and the water deep; so that no storm comes on from that quarter without some vessels coming in for shelter. I went out to the VOL. I. 
leeward of the rocks of the peninsula on which the inn is built, and, accompanied by Fred, sat some time watching several vessels come in, driving like leaves before the storm; and it was a relief to my mind as each vessel in her turn swung round to her anchor, having weathered the head of the peninsula and entered the sheltered bay formed by the land on which the inn stands, where they rode in perfect safety in tolerably smooth water. Notwithstanding a stream which $I$ found in the morning running through my bedroom, I slept soundly enough. The wind and rain had somewhat abated, and I walked across the country towards a fine headland, some six or eight miles off, called Whiten Head. The rain coming on again obliged me to return without quite reaching it. The entire coast here is very grand and steep, exposed to the whole force of the ocean: the rocks are cut up and weather-beaten to a degree unknown in more southern or more sheltered countries.

In the course of my walk I came to the mouth of the river Hope, which runs into the sea halfway between Heilam and Whiten Head. The course of the river is very picturesque, forming as it does a green glen covered with grass and foliage in the midst of the dreary gray country which surrounds it. I am told that a great number of salmon ascend 
into Loch Hope when the river is tolerably high. In a corner sheltered by rocks and birch-covered banks is a solitary hut, where Mr. Hogarth's fishermen live during the fishing season, to be at hand to attend to the nets laid in the sea at the mouth of the river. This hut was on the other side of the stream, which was then much swollen; but a fisherman immediately came out and crossed in a boat to where I was standing: it seeming quite an agreeable surprise to him to have a human being to speak to in that lonely spot. He complained of the mischief done to his nets by seals; and also said that great numbers of otters were living about the rocks near the river. The number of cormorants was very great; on firing off my gun on the top of the rocks along the coast they flew out from beneath my feet in scores. These birds and rockpigeons seemed the principal inhabitants of the cliffs, with the exception of some pairs of ravens and hooded crows. On Whiten Head different seafowl and a pair of eagles breed every year. The people say that the nest of the latter is quite inaccessible. The grouse seem nearly extinct about this district, owing to the number of their enemies, in the shape of winged and ground vermin. I was delighted, however, with the song of the ring-ousel, which was to be heard from every grove and clump 
of birch. Notwithstanding the peregrines and crows too, the golden plover is in great abundance.

I found on the little promontory of Heilam a number of wild-flowers growing amongst the short grass, one or two of which were new to me. Though I am sorry to say that I am no botanist, I seldom pass a wild-flower without making its acquaintance.

The next day our drive was to Durness. The mountains at the head of Loch Erriboll are as wild as can well be imagined; consisting of irregular piles of gray rocks, thrown together in every kind of confusion. On the west of the loch there is a long slope of brown hill, down the side of which run innumerable small streams of the brightest water. The rain of the day before made them appear to great advantage, as they were all seen conspicuously from the opposite side of the bay, glittering in the gleams of sunshine, which occasionally broke through the remains of the storm. I was glad to get back to Durness after three or four weeks' absence, as the scenery is magnificent, the inn comfortable, and the landlady, Mrs. Ross, and her servants, most attentive, kind, and obliging. A pleasanter sojourn for botanist, naturalist, or lover of romantic scenery I do not know.

There is a very remarkable cavern close to Durness : a burn of good size disappears underground, 
and is seen again issuing from the rocks within this cavern, through which it runs for a short distance till it empties itself into the sea.

Numbers of the common house martin were flying about the cave, and building their nests in the niches of the rocks. In some of the dark, damp corners, where there seems to be a constant dripping from the roof, were clusters of bright green ferms, and other plants, in great variety. On some parts of the shore the rocks are quite perpendicular for a great height-I should say about three hundred feet; in others they are worn into numerous fantastic shapes and caverns by the action of the waves.

Although the wind had now fallen, the swell was tremendous, dashing the spray half-way up the rocks. It was a curious sight to see the rock-pigeons flying rapidly into the caves, sometimes dashing like lightning through the very spray of the breakers, scarcely topping the crests of the waves, which roared and raged through the narrow caverns where these beautiful birds breed. The rock-pigeons were very numerous here, and constantly flying between their wild but secure breeding-places and the small fields about Durness. I shot a few of them, and found their crops full of green food, such as clover, the leaves of the oat, etc.; a number of small shells were also in the 
crop of every bird. The rock-pigeon is a very beautifully-shaped little bird, rather smaller and shorter than the common house-pigeon, of which it is plainly the original stock. They seem very restless, seldom remaining long in one field, but constantly rising and flitting away to some other feeding ground, with an uncertain kind of flight; but when alarmed, or going straight home, they fly with very great rapidity. They are easily tamed when caught young. The eggs seem very difficult to get at; nothing but a ladder will enable a person to reach them, and it is almost impossible either to procure such a ladder, or, if procured, to carry it to the caverns where they breed.

There were two or three beautiful wild-flowers near Durness which I had not seen before. They grew on the short grass that covers the summit of the cliffs. I picked up, while wandering about there, some of the small land shells with yellow and black stripes (Helix nemoralis), exactly similar to those which, when a child, I used to find on the South Downs, near Brighton. The rocky headlands jutting into the sea near Durness are very bold and abrupt. While looking for rock-pigeons I saw a few of the red-legged crow, or Cornish chough, passing from rock to rock, and busily employed about the broken stones searching for food. 
From Durness to Rhiconnich is about fourteen miles of hilly road, passing through the same description of rocky country, abounding in wildcats, martens, and other animals of prey. There is a loch about two miles from Durness where I was told that char are very plentiful. All the lochs abound in excellent trout.

We reached Rhiconnich, a tolerable inn, but certainly not so well kept as many others in Sutherlandshire, at eleven o'clock, and immediately started for a lake some two or three miles off, where the osprey was said to build. The way to it was far too rocky and steep to take the boat, so we only took my swimming belt, as Dunbar offered to swim out to the nest, if not too far from the shore. We had a very rough walk of the longest two miles that I ever met with. Our route was over a continuous range of rocky ground-so broken that we seldom found a flat place to put our feet on. We did not find the right lake immediately, but at last saw from a height a larger piece of water than any we had hitherto passed, and at some two hundred yards from the shore there was the conical-shaped rock, which the osprey always seems to choose for her nesting place.

On examining the rock with the glass we immediately saw the nest, and the white head of the 
bird in the middle of it. Our troubles were instantly forgotten, and although rather fagged before, we made our way over the rocks with new-found vigour. The unwillingness of the old bird to leave the nest showed that she had young ones. While Dunbar prepared to take the water I went round to watch for a shot at the old bird. I presently saw nothing but my fellow-traveller's head, as he swam gallantly out to the rock: the old osprey flew in wide circles round and round, at a considerable height, screaming loudly at the unexpected intrusion on her domain; sometimes she swooped half-way down to the water, but still cautiously keeping at a safe distance. Before many minutes had elapsed we saw the male bird sailing high in the air, straight to the loch; on hearing the cries of his mate he seemed to quicken his flight, and soon joined her, carrying a trout in his talons. The two birds then sailed round and round the water with loud cries. When they saw Dunbar perched on their hitherto unassailed rock, and looking like a statue on a pedestal, their excitement became greater and greater; the male dropped his trout, and they both dashed wildly to and fro, sometimes at a great height, and sometimes taking a rapid circuit of the lake, within half a gunshot of the water. The next thing I saw was my 
adventurous companion striking out for the shore, with his cap in his teeth. In the nest he found a half-grown young bird and an unhatched egg, both of which he brought safely to land. He remained on the spot to try to shoot one of the old birds, while I fished for an hour down a stream that ran from the loch towards the inn. I think it was the most rugged and rocky that I ever threw a fly on, but though it was difficult to imagine where trout could lie in it, I managed to half fill my basket with very nice-looking fish.

After resting ourselves for an hour or so, we again left the inn to look for another osprey's nest in the contrary direction. We could get but very vague information as to the exact point of the compass we had to make for; one person telling us that the lake was only a mile and a bit off; another that it was two miles and a bit, and so on. However, it was only about half-past five, and, with the long summer's evening before us, we cared little where the lake was, as long as we could find it at all. 'There were a few scattered houses along the banks of the sea-loch at the end of which Phiconnich is situated, and we made sundry inquiries at these respecting the lake, but got such very different answers from each person, that we were almost giving it up in despair; I should not say that we 
" inquired," as the whole talking was in Gaelic, and therefore carried on by Dunbar. At last we met with an old woman, who told him that there was a loch some two miles off, which had always gone by the name of the Loch of the Fishing Eagle; her Gaelic name for it being "Loch n' allan-yasker." I probably write the Gaelic incorrectly, but that was as near as I could make out what the name sounded like; Dunbar interpreted it to me as meaning literally, the "Loch of the Eagle-fisher."

This revived our spirits, and we set our shoulders to the hill again with fresh confidence, and a steep, rough hill it was. We struck into the country in a north-west direction, keeping separate heights, in order to have a better chance of finding the lake. Having passed several lochs without observing the object of our search, I began almost to despair, and to think that we must have mistaken the whole matter - the more so, as from the aspect of the rocks and the feel of the air from the north, I was confident that the ocean must be at no great distance from us ; and, indeed, that it must be washing the other side of the very next range of rocks to that on which we were. There is a certain look and feel of the atmosphere when approaching the sea, which is quite unmistakable. We had already walked an hour and a half straight north-west, thus making 
the two miles into at least five, when we came within view of a larger loch, which seemed to wind round the hills to nearly where the sea was. In this we again descried the peculiar-shaped rock on which the osprey builds. Although we were too far off to distinguish either nest or bird, we at once, without hesitation, made for the loch, over the rocks and swamps of which the whole line of country seemed to consist, and our perseverance was rewarded by presently making out that one osprey was on the nest, and the other soaring above her.

Dunbar again swam off to the rock, which was about the same distance from the shore as the last one was, and found three young birds in the nest, which he brought to land in his cap. I saw the male osprey perch on a rock on the opposite side of the loch, where he sat lazily, and apparently not inclined to join the female in her rapid flight round Dunbar's head; on looking at him attentively, through the glass, I saw, or fancied that I saw, his crop much distended with food. Knowing that if this was the case he would probably remain on his perch for some time, I started off round the loch, taking a long circuit in order to approach him from behind and from above. I had not calculated on the rocks I had to climb and the passes I had to take to get at him, or I do not think that I should 
have undertaken the task. I had frequently to lift my dog up the steep rocks over which I had to climb. At last I came to a point from which I could get a look at the bird, and with as much care as if he had been a stag, I crept to a convenient place, and looking over, saw him still perched on the pinnacle of a rock, but quite out of reach. I found that I must still make another long circuit, or that I could not get unperceived within reach of him.

This time, on looking carefully over, I saw that he must be within shot of me, but the place I was perched on was so high and steep that it almost made me giddy to look down from it. I was completely out of breath, too; so lying down on my back, I waited a minute or two, and then scrambled down to within forty yards of the bird, and immediately above him. As my gun was loaded with a cartridge, I knew that he could scarcely escape; so standing up, I took a good look at him, expecting that he would see me and fly off the stone, and intending to shoot him flying. Whether from the earnestness with which he was watching the movements of Dunbar, who was far below him, or from the manner in which his head-feathers projected, he did not appear to see me at all. After waiting a short time without his moving, I am sorry to say 
that I shot him deliberately in cold blood as he sat. He fell down the face of the rock, and lay at the bottom perfectly dead. I then had to consider how to get at him, and Fred seemed to be considering the same thing, as, peering over the edge of the precipice, he looked first at the dead bird and then at me, with a countenance expressive of "There is your bird now, but how are we to get at him?" This question, however, was soon settled by my marking the place, and then, having made a considerable détour, I managed to reach the spot. In the meantime, Dunbar having shot both barrels at the hen bird, she took her flight straight off to the sea. After a short time she returned, but kept at a wary distance, occasionally perching on the rocks, but never remaining long in one place. It was a curious sight from the high rocks, several hundred yards above the loch, to watch the whole scene that was acting below, and to see the long-winged bird sailing to and fro almost immediately below $\mathrm{my}$ feet, and yet far out of reach of shot.

The sun began to sink below the seaward rocks, lighting up only the highest summits of the hills to the south of the lake. On the very highest pinnacle of the rocks I saw several goats lying in different picturesque attitudes, to catch the last sumbeams, one old white fellow with renerable beard and long 
horns being on the topmost point of all. Whom they could belong to it was difficult to say - they seemed as wild as red-deer. Dogs who are accustomed to roe seem invariably to hunt goats. Returning homewards, Fred began to snuff the air as if he smelt something he was used to liunt. Expecting it to be a wild-cat or some vermin, I answered his appealing look by allowing him to go off in pursuit of whatever it might be. Off he went, scrambling over the rocks in a state of furious eagerness. After a short time, however, a small flock of goats rushed past me, with Mr. Fred in hot pursuit on their scent. Nothing would stop him, notwithstanding his usual obedience, so I left him to his chase, and some time afterwards he came up with us again, looking heartily ashamed, and having run himself well out of wind, the goats having probably got to some steep rock of refuge where no dog could follow them.

About ten o'clock, it being still quite light, we found ourselves above the sea, with our inn apparently some miles off, probably about three, and three miles of such walking as, after our hard day's work since three in the morning, we did not much fancy. Just then, however, we saw a boat going up the glassy loch towards our inn; so, hailing it as loud as we could, we managed to make the rowers hear us, and they having come to the shore, we with 
some difficulty scrambled down the rocks and got aboard. In the boat was what is here called a messenger-at-arms, which, I fancy, answers somewhat to a superior kind of constable. He had been on a strange and fruitless errand to arrest a girl of fourteen or fifteen, who had for some time been in the habit of driving the sheep in the neighbourhood on to a narrow point of land that reached into the sea, and having caught them one by one, she robbed them of as much wool as she could manage to strip off. Having carried on this system for some time, she at last became a perfect bugbear to the farmers, and here, luckily for us, was a well-dressed, rather dandy messenger-at-arms returning from his chase, and going straight to Rhiconnich, to which place he kindly gave us a lift, for which we were very grateful to him.

We had a beautiful row up the loch; but the cold air, after the great heat of the afternoon while climbing the rocks, joined to sitting for an hour in the boat wet through above my knees, gave me an attack of illness which eventually cut short my rambles in Sutherland.

Between Phicomnich and Scowrie I lost my only fishing-line in a ridiculous manner. In the course of our drive we passed over a very good-looking stream, the Laxford. Thinking to catch a couple 
of trout for breakfast, I put my rod together, and leaving the horse and boat standing by the roadside, I determined to take a quarter of an hour's fishing, and if the trout did not rise, to continue our journey. At the very first cast that I made, however, a large salmon took the fly, rather to my annoyance, knowing, as I did, that no salmon were allowed to be killed in the Sutherland rivers this season. But being once hooked, he might as well be killed, so the fight commenced by the fish running clear out of the stream in which he was first hooked, and going down like a stone to the bottom of a deep black-looking pool below. Having only single line and trout-tackle, I could not force him much, but after waiting patiently with a gentle but constant strain on the fish, in order that he might still feel some weight upon his jaws, I at last, in despair, gave him such a tug that he was dislodged from his resting-place in spite of himself. Off he went, sometimes across the stream, with nearly the whole of my line out, the next moment right under my feet in the deep pool under the rock on which I was standing, and from which it was not easy to move. There $I$ could see him shaking his head and trying to rub the hook out against the gravel; at another time he would take a sudden dart to the right and left, and again shake his head 
like a dog worrying a rat: but knowing that he was well hooked, and, indeed, not caring much whether I lost him or not, I kept so tight a rein on him as prevented his either slacking the line or rubbing off the hook, small as it was. Suddenly a new idea seemed to seize him, and shooting straight upwards, he leaped several times out of the water immediately below me. But this would not do; so finding that he could not get rid of the hook, he again rushed across the river, making the handle of the reel spin at a railway pace. He then made down the stream as fast as he could. I had scarcely any line left on my reel, so had to take a leap off the rock and follow him along the bank of the river. Presently we came to a rather rapid but not high fall, full of broken stones, and altogether a place where he would be sure to break my line if he once got into it, which he seemed determined to do, so here I halted and made a stand against all his pulling. The fish began to feel beat, and ran in again almost under my feet.

Not succeeding in slacking the line, he again rushed right across and took the fall, in spite of all I could do to prevent him. He did not cut my line as I expected, but it gave way close to the end, within a few inches of the reel, and before I could catch hold of it I had the pleasure of seeing the VOL. I. 
line floating away, but gradually sinking as the fish carried it off towards the wider pools near the sea, Dunbar jumped gallantly into the water, but was too late to catch it, so the salmon went off with about forty yards of line and a couple of sea-trout flies hanging to his mouth. I scarcely knew whether to be angry or amused, but considering that the former would be of no use, and perhaps spoil my appetite for breakfast, I undid my rod, got into the boat, and drove off to Scowrie to breakfast, with a philosophy that rather astonished my companion.

Having called on Mr. M'Tvor, the manager of this part of Sutherland, that gentleman offered me his boat and other facilities to enable me to go to see the island of Handa, which is situated some four miles from Scowrie, and is famous as the breeding-place of an immense number of sea-fowl. After as hour's easy row and sail over the beautiful bay of Scowrie, and skirting a range of most rugged rocks, we approached the island. On the south side, where we landed, it has the appearance of a fine green slope, with only a range of low rocks immediately adjoining, and reaching in long points into the sea. About these rocks we saw thousands of sea-gulls and cormorants, and on the point that projected farthest into the water sat a large white 
cat, looking wistfully towards the mainland. As all the inhabitants had left the island early in the spring for America, this cat had probably remained behind, and had made her living as she best might out of small birds, dead fish, etc. I could not help being struck with the attitude of the poor creature, as she sat there looking at the sea, and having as disconsolate an air as any deserted damsel. "She is wanting the ferry," was the quaint and not incorrect suggestion of one of our boatmen. Having run our boat into a small sandy creek, we landed. Here, as everywhere round the coast, is a fishing-station of Mr. Hogarth's, if a hut, the summer residence of two forlorn fishermen, can be called a fishing-station. We borrowed another coil of ropes from these men, and proceeded to the northerm side of the island, where the perpendicular rocks form the breeding-places of the sea-fowl. The distance across the island I should reckon at nearly two miles, and it is a continued slope of green pasture. I passed several huts, the former inhabitants of which had all left the place a few weeks before; and, notwithstanding the shortness of the time, the turf walls were already tenanted and completely honeycombed by countless starlings, who seemed not the least shy, but, on the contrary, kept their ground, and chattered away as if they looked 
on me as an intruder on what they had already established their right to.

Leaving them in undisturbed possession, I continued my way on to the north side, and in due time arrived on the summit of the cliffs which stretch the whole length of the island; and there was a sight which would alone repay many a weary mile of travel. Every crevice and every ledge of the rock was literally full of guillemots and razor-bills, while hundreds of puffins came out of their holes under the stones near the summit of the cliffs to examine and wonder at us. The guillemots stood in long lines along the shelves of the rocks, frequently within a few feet of the top whence we were looking at them. With a kind of foolish expression these birds looked at us, but did not take the trouble to move. The razor-bills, though equally tame, seemed more ready to take flight, if we had been inclined to assail them. When I fired off my gun, not at, but over, the birds, the guillemots only ducked their heads, and then looked up at us; whereas most of the razor-bills took a short flight out to sea, but quickly returned again to their perch on the rocks.

Being provided with plenty of rope, two stout boatmen, and also a slender-looking lad, who had volunteered to accompany us, having the repute of 
a good cragsinan, we lowered the latter over the top in order to procure a few eggs. I was amazed at the confidence and ease with which the lad made his way from shelf to shelf, and crevice to crevice of the precipices. From habit and custom he seemed to be as much at his ease as if he had been on fair terra firma. As for the birds, they would scarcely move, but just stepped out of reach, croaking at him with their peculiar note.

Each bird has a single egg of a size so large as to appear quite disproportioned. The eggs are of all colours, and marked in a thousand fantastic manners, sometimes with large blotches of deep brown or black, sometimes speckled slightly all over, and others having exactly the appearance of being covered with Arabic characters. The prevailing groundwork of the eggs is greenish blue, but they vary in different shades from that colour to nearly white. The egg is placed on the bare rock, with no attempt at a nest; and it was very amusing to see the careful but awkward-looking manner in which the old bird, on her return from the sea, got astride, as it were, of her egg, spreading her wings over it, and croaking gently all the time. Occasionally an egg would get knocked off by some bird in taking flight from the rock, to the great indignation of its owner. 
Leaving Dunbar to collect his eggs, I strolled off alone along the summit of the cliffs, sitting down here and there to watch the different proceedings of the birds; and it was a most curious sight. On lying down to look over the most perpendicular parts, the constant and countless clouds of birds that were flying to and fro suggested the idea of a heavy snow-storm more than anything else, so crowded was their flight, and so high was the cliff. The guillemots seldom came to the top, but the razor-bills and puffins, particularly the latter, came fearlessly close to me. Indeed the puffins seemed to have the most entire confidence in my peaceable intentions, and frequently alighted so near me, that I might have knocked them down with a walking-stick. Sitting on a stone, they examined 'me most curiously, twisting their oddlyshaped heads to the right and left, as if to be sure of my identity. In some parts of the rocks there were great collections of kittiwakes' nests. These birds, unlike the guillemots, etc., construct a goodsized receptacle of weeds and grass for their eggs. In the midst of all this confusion and Babel of birds, a pair of peregrine falcons had their nests, and on my approach they dashed about amongst the other birds, uttering loud cries of alarm and anger. Towards the east end of the island was the nest of 
the white-tailed eagle. The old birds flew far away immediately, and I only occasionally saw them as they soared high in the air. The nest was so completely under a shelf of rock that nothing but the ends of the outer sticks could be seen. I had not time to make any decided trial to get at it, as I had promised to be with Mr. Mror at six o'clock; and my intention of visiting the place the next day was frustrated.

The rocks are curiously indented by the sea; in one place the waves have cut a kind of deep crevice the whole height of the cliffs, for a good distance into the island, through the narrow entrance of which the swell was roaring with a noise like thunder. At another part there is an island, or stack, as it is called, within a stone's throw of the mainland, but quite isolated. It is in the shape of a sugar-loaf, with a flat summit of perhaps twenty yards across. The top was covered with green herbage, and swarmed with birds of different kinds. Amongst them were great numbers of black-backed sea-gulls, both the greater and the lesser.

In the quieter parts of the cliffs were rockpigeons and cormorants; neither of these birds seemed inclined to associate much with the crowd of sea-fowl which filled the greatest part of the rocks. Their stench alone might drive away so 
delicate a bird as a rock-pigeon, and bad as this was now, by the time they had hatched and reared their young it must be much worse.

The rest of the party having joined me, and the time running short, I left the island in order to fulfil my promise of partaking of $\mathrm{Mr}$. M'Ivor's hospitality at six o'clock; and I must say that after living so many days at small inns where I could, and how I could, an evening spent in the agreeable society of Mr. M'Ivor and the ladies at his house was a treat, as I had begun to feel like an uncivilised being.

On leaving the island we again saw the white cat seated on the same point of rock, and still looking anxiously towards the mainland.

Limited in size as the island of Handa is, it seems to contain a fine range of rich herbage, with a gentle slope to the south, and to be capable of feeding a considerable number of sheep or cattle. I was told, however, that much loss is sustained from the animals falling over the rocks, when they are inevitably dashed to pieces. 



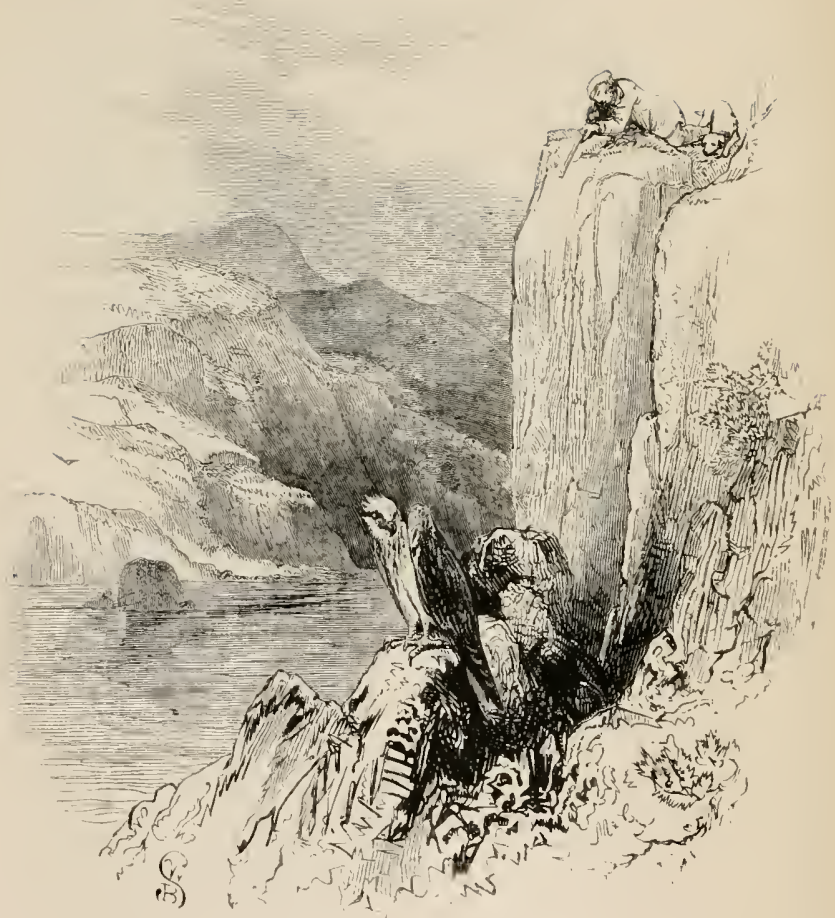

Loch near Rhiconnich.

Vol. i. p. ro5.] 


\section{CHAPTER VII.}

Another Osprey's Nest; Variety of Eggs-Golden Eagle; Manner of Hunting; decrease of-- Egg Collectors-Mr.

Hancock's Collection-Nests of Eagles; Animals killed byThe Mountain Hare-Fishing of Osprey.

Two miles from Scowrie, on the Rhiconnich road or near it, is a loch where the ospreys build, and where, in May, I shot the old hen, taking at the same time two eggs. Mr. Dunbar, with his usual perseverance, went to this nest immediately on our return from Handa, and found that the male bird had got another mate, and that she was already busily employed in sitting on a single egg.

It is very difficult to describe correctly the eggs of many birds : for instance, the two eggs which I took from this nest were beautifully marked with fine rich red spots, while the egg now taken by Dunbar was of a dirty white colour, marked at one end only by a splash of brown, and was also smaller than the others. In another nest, again, the eggs were considerably larger than either of these, and differently marked both as to colour and shape of spots. In the same manner one reads the description of the size of birds as being measured to inches 
and sixteenths of an inch, but the authors forget or are not aware of the constant difference of size in birds of the same species.

We also examined the nest that we had seen in May last near the ferry of Glendha, or Kyleska as it is also called. On looking at it with a glass, we saw one old bird sitting, not standing, on the nest, and yet on Dunbar's swimming out to it he found no egg in the nest, which was exactly in the same state as when we left it three or four weeks ago: both birds, too, continued sailing and screaming over our heads as if they had eggs or young ones to defend. This nest, like the last three that we had seen, was built on the same kind of conical rock, standing out of the waters of the lake; indeed, on all the lakes where this singularly-shaped rock was to be seen, there also was the osprey's nest, and there it had apparently been for many a long year, as was clearly shown by one of the lochs being known by the old people only under the name of the loch of the "Eagle Fisher."- The ospreys, on their arrival in this country, seem to seek out these rocks in the wild solitudes, and on these and these alone do they build. Trusting to their isolated and lonely situation for safety, these interesting birds hold undisputed sway over their watery kingdom. I could not help being reminded 
of a couple of lines which I fell in with, that seem $\dot{a}$ propos to this instinct of the osprey which leads her to find out and take possession of all the rocks of this particular shape that are to be found in the lochs of Sutherland:-

\section{"Ni fallat fatum Scoti quocunque locatum}

Invenient Lapidcm, regnare tenentur ibidcm."

\section{I cannot remember whom I quote from.}

We drove again through the magnificently wild country which intervenes between Kyleska and Inchnadamph. Above the shoulder of the mountain, which stands conspicuously in front of the inn, a golden eagle was hunting. The distance at which this bird can see her prey has often been talked of, but I never saw her power in this respect so fully displayed as on this occasion. The eagle was hovering so high in the air that she looked like a speck, when suddenly she distinguished a grouse on the heather; even at that immense distance. The height was too great to make a direct swoop, so the noble bird, instead of coming down straight at the grouse, almost closed her wings, and wheeled with rapid circles downwards from her first height, till she was within a more moderate distance from the ground. The grouse seemed then to have hidden itself, for the eagle remained hovering for a few minutes, turning 
her head in every direction, as if she had lost sight of her victin ; when, suddenly catching a glimpse of the poor bird, down she came with extended legs, and without seeming more than to touch the heather with her talons, she caught the grouse, and the next moment was flying rapidly away towards the highest cliffs of the mountain with her prey.

Notwithstanding the incessant war waged against these noble birds, there are still some few eagles left in certain districts; but where there is much grouse-shooting, and where, in consequence, there are many keepers, they are quite extirpated. The shepherds seem too indolent to take much trouble about killing the old birds; though the mania for collecting birds' eggs bids fair, I fear, to prevent any number of young eagles being hatched, as the eggs have become in such demand that they fetch from a pound to five-and-twenty shillings each from the numerous collectors, who, by-the-by, are constantly imposed upon most grossly in their collections.

The most perfect arrangement of British eggs that I ever saw, and one that is quite to be relied on for the identity of every egg, belongs to my friend Mr. Hancock of Newcastle-a gentleman who combines with the most indefatigable and zealous love of nature in all her forms, a refined 
taste and acute perception that no trick of the trade can impose upon.

Mr. Hancock's collection comprises very nearly every British bird's egg, and many varieties of each kind, which he has collected, from public-spirited motives, at an incalculable outlay of time and expense, aided by a perfect and intimate knowledge of every bird, both in its living state and habits, and in its anatomical structure and formation.

Notwithstanding, as I say, the prices given by London collectors, the sea-eagle, at any rate, is tolerably common on the northern coast and islands. From its habit of building principally on the most inaccessible rocks and cliffs of the sea-coast, its nest is more secure than that of the golden eagle, which, building farther inland, and frequently in more accessible places, is liable to be killed, or to have its nest taken by shepherds, keepers, etc.

The eggs of these two eagles are very similar to each other; but the different specimens of each sort vary considerably in size and colour. I have seen golden eagles' eggs of many different shades, from one of a pure white to one covered with light red spots; and the white-tailed eagle's eggs vary in the same manner. The eggs of both have a fine strong character about them, which is difficult to understand without seeing the egr. The nests of both 
kinds are generally formed of sticks of an astonishing size, frequently as large in diameter as a man's arm - these, too, brought from a considerable distance; sometimes it is impossible to say where they can have procured them. The white-tailed eagle does not hesitate to use the coarse sea-ware and tangle for her nest. They build not only in the steepest possible cliff, but generally take advantage of some overhanging shelf, which, concealing the nest from above, makes it doubly secure; occasionally, however, I have known a golden eagle build in a place where an expert climber could reach the nest without the aid of ropes.

The remains of game of all kinds common in the mountains are found in great abundance about their nests when they have young; lambs also, and near the deer-forests young red-deer, are taken up to the nest. I cannot say whether they carry up the latter animals whole or not, but their remains always form part of the larder found at an eagle's abode, if it is in a situation where deer abound. The weight of a newly-born red-deer calf is not great, and, once in the air, the eagle would carry one easily enough. Instances have occurred of an eagle attacking a person when engaged in robbing lier nest, but, generally speaking, they have a proper dread of man and fire-arms. Nevertheless I have known 
some well-authenticated instances of this fear being entirely put aside ; indeed it could scarcely be otherwise with so powerful and fierce a bird as an eagle, when so weak and timid a bird as a partridge has been known to fly at and strike a man's legs like a gamecock on her young ones being too nearly approached. This I have seen happen, and therefore I can easily believe that an eagle may do the same in defence of her young.

:The actual damage done to game by eagles is, in my opinion, comparatively small, the favourite food of these birds being the mountain hare, and every sportsman knows that the fewer of these animals he has on his ground the better: where they increase too rapidly (and no animal does increase more quickly) they become a perfect plague to grouse dogs, for however well broken your setters and pointers may be, the manner in which mountain hares run cannot fail to make the dogs fidgety and anxious, besides tainting the ground. Instead of running clear away when started, like the common lowland hare, this animal (Lepus albus) hops quietly from before the dog's nose, and stops to sit erect on the very first hillock she meets with, within a hundred yards of the dogs. When again approached she repeats the same trick, and frequently remains for a quarter of an hour going slowly in front of the 
dogs, and sitting up on her hind legs in full view of them ; in this manner not only tainting the ground with her scent, but, as it were, challenging the dogs to a trial of speed. Notwithstanding the good training one would suppose these inhabitants of the mountain ought to be in, they are easily run down, even by a quick colley dog. I know of some grouseshootings where these hares have increased to such an extent, owing to the destruction of vermin, that they have been killed by hundreds in a day, and are shot down at all seasons as a nuisance. A few eagles on such ground would be of great service.

When mountain hares are not to be had by the eagles, they feed more on carrion, such as dead sheep, than birds, a good-sized dead animal of this kind being far more suited to the ravenous appetite of a golden eagle than a small bird like a grouse; and in the sheep districts there must be a constant supply, owing to accidents and disease.

In the month of May I saw the nest of an osprey on the very summit of the old castle built on a point of land (sometimes an island) in Loch Assynt. The nest was then tenantless, and had been so for two or three years. On my return in June, I was much pleased at seeing one osprey on the nest and another sailing over the loch.

Though the osprey is, generally speaking, so very 
rare in Britain, it frequents this locality, which seems particularly to suit it. Large tracts of the country here are almost unseen by human beings from one end of the year to the other. Covered with gray rocks, and broken up into a succession of small hollows, in most of which there are lochs, all abounding in trout, this district is exactly suited for the osprey, while it is unfit for any other animal; the sheep remain more on the extensive and grassy slopes, where they not only find plenty of food, but are more under the eye and protection of mankind. A shepherd in the broken, rocky tracts of country can have no chance of finding or seeing his flock; while, at the same time, the pasturage is worth but little, consisting wholly of rank heather. Nor is the ground at all better adapted for the grouse shooter, as he would never keep sight of his dogs for two minutes together. For these reasons the osprey is but little disturbed, and lives unmolested for years. Even if a shepherd does pass the loch, the bird sits securely on her isolated rock, out of reach of all danger, as her nest can only be approached, in most instances, by swimming. I generally saw the osprey fishing about the lower pools of the rivers, near their mouths, and a beautiful sight it is. The longwinged bird hovers (as a kestrel does over a mouse)

VOL. I. 
at a considerable distance above the water, sometimes on perfectly motionless wing, and sometimes wheeling slowly in circles, turning her head and looking eagerly down at the water; she sees a trout when at a great height, and suddenly closing her wings, drops like a shot bird into the water, often plunging completely under, and at other times appearing scarcely to touch the water; but seldom failing to rise again with a good-sized fish in her talons. The feet of the osprey are extremely rough, and the toes placed in a peculiar manner, so as to give the best possible chance of holding her slippery prey. Sometimes, in the midst of her swoop, the osprey suddenly stops herself in the most abrupt manner, probably because the fish, having changed its position, is no longer within her range; she then hovers again, stationary in the air, anxiously looking below for the reappearance of her prey. Having well examined one pool, she suddenly turns off, and with rapid flight takes herself to an adjoining part of the stream, where she again begins to hover and circle in the air. On making a pounce into the water, the osprey dashes the spray up far and wide, so as to be seen for a considerable distance.

The rapidity and certainty of stroke that a bird must possess to enable it to catch so quick a creature as the sea-trout can scarcely be understood. One 
would naturally suppose that the trout, in its own element, would give a bird not the slightest chance of catching it, particularly as this can only be done at one dash, the osprey, of course, not being able to pursue a trout under the water like a cormorant. All fly-fishers must know the lightning-like rapidity with which a trout darts up from the depth of several feet, and with unerring aim seizes the fly almost before its wings touch the water; and yet here is a large bird, hovering directly over, and in full view of the water, who manages to catch the rapid-darting trout with an almost certain swoop, although one would naturally suppose that the fish would be far off, in the depth of the pool, or behind some place of refuge, long before the bird could touch the water. In the same manner it has often puzzled me how the terns can with such certainty pounce upon and catch so quick a little fish as the sand-eel : the tern's feet not being at all suited for holding anything, these birds catch the sand-eel with their bills.

The osprey is not nearly so early as the eagle in breeding; in fact the latter is far advanced towards hatching her eggs before the osprey arrives in Scotland. It is said the ospreys always arrive in pairs; if so, however, it is not easy to understand how, when one out of a pair is killed, the re- 
maining bird can find a mate, which it generally manages to do. There are, too, but very few in Britain at any time, their principal headquarters seeming to be in America; and though living in tolerable peace in the Highlands, they do not appear to increase nor to breed in any localities excepting where they find a situation for their nest similar to what I have already described. As they in no way interfere with the sportsman or others, it is a great pity that they should ever be destroyed.

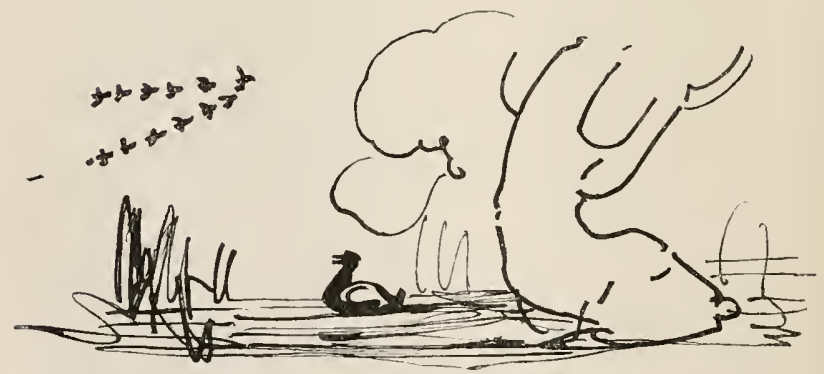




\section{CHAPTER VIII.}

County of Sutherland; Variety of Climate and Soil-List of Birds ; of Hawks ; Owls ; of the smaller Land Birds ; of the Crow 'Tribe; Pigeons, etc.

There is no county in Britain with a greater variety of soil and climate than Sutherlandshire, changing gradually from the rich and highly cultivated farms on the Dornoch Firth to the gray rocks and mountains of Assynt and Scowrie. The living productions are also as varied and numerous as can be found in any district of our island. There are few British birds or quadrupeds that are not to be found in this county; the vegetable productions, cultivated and uncultivated, are as numerous and varied.

The first agriculturists in England would delight in the fine farms near Dunrobin, and might perhaps take a lesson or gain a hint from the tenant's management of cattle and wheat, most of which is destined ultimately for the London market. Though no farmer myself, I pulled in my horse for some time to admire the numerous and beautifully kept cattle and crops of Mr. Craig of Kirkton, one of the Duke 
of Sutherland's most skilful and enterprising tenants. His cows would have gladdened the eyes of any Devonshire or Cheshire dairywoman, as they did mine, a simple admirer as I am of beauty in any living animal, from a milk-cow to a field-mouse.

There is an air of well-doing and comfort about the farms on the Duke of Sutherland's property which is delightful to the passer-by, and must be doubly so to the kind and liberal landlord. Very striking, too, is the different appearance of the tenantry on some neighbouring properties, where, to keep up a forced and contemptible show, the proprietor rack-rents his tenants to the very utmost pitch of endurance.

I will endeavour to give, for the use of the naturalist, a list of the wild-birds of the county ; which he must take, however, exceptis excipiendis, as a list of an unscientific observer of nature.

To begin with the finest of our indigenous birds :-

1. The Golden Eagle is still to be found tolerably numerous, but gradually decreasing, in the north and north-west part of the county, though likely to be soon extirpated, owing to game-preserving and sheep-farming. To the latter the eagle is far more destructive than to the former. 
2. The Cinereous or White-tailed Eagle is perhaps more numerous than the Golden Eagle ; living, as it does, principally in the lofty cliffs of the seacoast, and feeding more on dead fish and food found on the shore, it does not so often fall in the way of the trapper or fox-hunter: it breeds, sometimes, amongst the inland mountains. The White-tailed Eagle, though larger than the Golden, is not so handsome nor finely formed and coloured a bird. All other varieties of the eagle found in the Highlands are merely these birds in different states of plumage, owing to sex or age, as there are only these two distinct kinds of eagle in Britain.

3. The Osprey is more rare and local than either kind of eagle. Though not a very heavy bird, its breadth of wing nearly equals that of the Golden Eagle. The habitat of the Osprey is confined to the north-west part of the county, where the numerous lochs, well supplied with trout, afford this bird both refuge and food. The principal, if not the only places in which it breeds, are Loch Assynt; a loch two or three miles north of the ferry of Kyleska; a loch three miles eastward of Scowrie; two of the fresh-water lakes near Loch Inchard, at the head of which is the inn of Phiconnicls; and, again, on Loch Maddie, the Osprey occasionally frequents a nest built on an old birch-tree in an island. 
4. The Peregrine Faleon comes next to the Osprey. There are few ranges of lofty and precipitous rock where this bird does not breed. The nest is difficult of access, and the old birds shy and wary; nor are they easily trapped, as they do not condescend to feed on any game which they have not killed themselves: grouse, plovers, and wildfowl seem to be their principal food.

5,6 . The Hobby or Goshawh I never saw in this county, though I have no doubt of their being frequent visitors here, particularly the former. The Goshawk seems very rare everywhere in Scotland.

7. The Merlin, the smallest of our British falcons, is not uncommon; it builds in the long heather, and preys on small birds, snipes, etc. Bold and courageous, it will sometimes attack birds much larger than itself. Owing to its high spirit and daring the Merlin is not difficult to train for hunting, and this beantiful little bird seems to have been in former days the peculiar hawk used by ladies :-

"A merlin sat upon her wrist,

Held by a leash of silken twist."

Its light weight would weary no lady's arm.

8. The Kestrel is common everywhere, from north to south of the county; building in every cliff and rocky burn. Though ignorant game- 
keepers destroy it, the Kestrel, preying principally on mice, does far more good than harm.

9. The Sparrow-hawh usually frequents the more woody parts of the county. Bold and courageous, it strikes and bears away a common pigeon with apparent ease.

10. The Kite being a large, greedy bird, and easily caught in traps, is very rare now-common as it was a few years ago. In the wooded districts it is still, though but seldom, seen soaring with graceful flight high in the air. By repute the Kite is a great chicken stealer, and when she has young of her own to provide for, no bird destroys more grouse, young hares, etc.

11. The Common Buzzard a few years ago was very common, but now has been completely exterminated, excepting in the wilder districts. With its fine soaring flight the buzzard is a most interesting bird. In all its habits it appears to me to resemble the eagle more than any other kind of hawk.

12. The Hen Harrier is plentiful enough in the hilly districts, and, though very destructive to game, it compensates for this in some degree by occasionally preying upon rats, vipers, etc. The cock is distinguished from afar by his nearly white plumage; while the hen in her plain dress of brown is best known by the white ring on her tail, unde 
derivatur her name of ring-tail. The young male has the same plumage as the female.

13. The Ash-eoloured Harrier (Faleo eineraeeus) breeds near Bonar Bridge. Mr. Dunbar has taken the nest and killed the old birds in that district.

I do not know for a certainty of any other hawks breeding in this county, but probably the Marst Harrier, Honey Buzzard, etc., are occasionally met with.

14. The Scops'-eared Owl has been found to breed near the Oykel river, having her nest on the heather. ${ }^{1}$

15. The Long-eared Owl breeds commonly in the fir plantations, or in ivy-covered rocks.

16. The Short-eared Owl migrates to this country in October, and, unlike other owls, is found constantly in turnip-fields, rough grass, etc. This kind hunts frequently in the daytime.

17. The Common White Owl lives, as in England, in old buildings, rocks, etc., and, as it preys almost wholly on mice, ought never to be destroyed.

18. The Common Brown or Tawny Owl lives principally in the woody districts, where it is very common. In the frosty clear nights of winter this bird is heard hooting and uttering strangely wild cries. In the spring it comes abroad at an earlier hour than any other owl; and sitting on the top-

1 Query, Short-eared Owl. See Appendix, page 333. 
most and leafless bough of some ash or larch tree, may be seen puffing out its neck and hooting loudly.

19. The Snowy Owl is not unfrequently driven over to the north and north-east coast after severe gales from that quarter.

20. A specimen of that beautiful little species called T'engmalm's Owl was killed in May 1847, by Mr. Dunbar, in an old ruined factory at Spinningdale, in Sutherlandshire. This and many other foreign birds may be, and most probably frequently are, driven over to the wild and solitary eastem shores of the county without being seen or heard of.

I must here put in a word for owls. They are most unjustly and ruthlessly persecuted. Most owls are not only harmless, but in fact they are of infinite service to mankind. Hunting chiefly by night, when almost all young birds are safe in their roosting-places, the owls prey principally, if not entirely, on mice and rats, which are then abroad in all directions plundering the farmer's produce. Where the owls have been much destroyed by pole-traps and other means, mice and rats increase to the most mischievous extent, not only destroying grain, but also doing immense mischief in young plantations, by barking and nibbling the shoots of the young trees sometimes to an almost inconceivable extent.

21. The Spotted Flycatcher is common enough. 
Tame and familiar, it builds its well-concealed nest in the creepers and ivy that grow round a window or against the garden-wall. It arrives in May and departs early in autumn. Being dependent on flies for its subsistence, the first approach of cold drives this bird from the north to seek a warmer climate.

22. The Water-Ousel enlivens most of the mountain streams with its lively motions and merry note. In winter it comes nearer to the sea for unfrozen water, while in summer it is seen everywhere from Cape Wrath to Dunrobin.

23. The Common Ring-Ousel cheers the wanderer through all the wilder parts of the county, suddenly breaking out unexpectedly into loud song in places where the eagle or grouse would be more looked for than a singing bird.

24. The Missel Thrush is common, breeding very early. I saw it as far northward as Tongue.

25. The Common Song Thrush is to be seen wherever there is wood.

26. The Blackbird, though not quite so common, is plentiful also.

27. The Fieldfare and Redwing arrive in great numbers, and do not depart till some time in April.

28. The Hedge Sparrow breeds in every hedge in all the cultivated parts of the country. 
29. The Robin, with its usual sociability, frequents the habitations of man, as in other countries.

30. The Redstart breeds commonly about the woody glens and gardens near Dunrobin; but, like most other insectivorous birds, departs for the south on the first approach of winter.

31. The Sedge Warbler, singing like the nightingale during all the hours of darkness, is common. I heard its sweet note constantly during the nighttime: generally it sings about reedy lochs and swamps. The most northern spot at which I heard this bird was at Tongue, where its song was easily distinguished, and had a most pleasing effect amongst the harsher notes of the landrail, redshank, sea-gulls, etc.

32 . The Willow Wren is also met with wherever there are hedges or plantations.

There may probably be many other birds of the same family, unobserved by me, in the extensive woods of the southern parts of Sutherlandshire.

33. The Golden-erested Wren is very numerous throughout the year.

34. The Fire-erested Wren (Regulus ignieapillus) is sometimes met with. Mr. Bantock, the Duke of Sutherland's gamekeeper, who has a collection of birds killed on the property, showed me one specimen. Being very like the golden-crested 
wren, this bird may be much commoner than is supposed.

35. The Picd Wagtail; 36. The Gray Wagtail; and 37. The Yellow Wagtail, — are all numerous, ${ }^{1}$ particularly the two former.

38. The Titlark abounds in every part of the open and high districts, frequenting the summits even of the highest mountains, where it feeds on the numerous insects to be found amongst the stones and plants.

39. The Rock Pipit is very similar to the lastnamed bird; it frequents the sea-shores.

40. The Wheatear, coming early in the spring, ranges over the whole county, and is very abundant along the roadside in all the mountainous districts. It departs in the winter.

41, 42. The Whin Chat and Stone Chat are to be seen in all the rough grounds where furze and broom are abundant.

43. The Great Titmouse; 44. The Blue Titmouse; 45. The Cole Titmouse; 46. The Longtailed Titmouse,-all enliven the woods and plantations throughout the year. Although not exactly migratory birds, all the Titmice, as well as the Golden-crested Wren, seem nearly constantly on the move, passing from tree to tree, from hedge to hedge, from wood to wood, and in fact from dis-

${ }^{1}$ Doubtful statement. J. A. H.-B. 
trict to district, to wherever the insects on which they prey are most numerous.

47. The Bohemian Waxwing, a very beautiful bird, though not a native, is occasionally killed in Sutherland; as are

48. The Hoopoe; and 49. The Rose-coloured Starling, and probably many other continental visitors.

50. The Sky Lark is seen everywhere, having few enemies excepting the merlin and other small hawks.

51. The variety of sky lark called the Crested Lark is also found about Assynt. ${ }^{1}$

52. The Snow Buntings arrive in great numbers in October. As the frost and snow increase, the male birds daily become whiter. They appear to be never at rest, flitting to and fro along the seashore, or other places where they find their minute food.

53. The Corn Bunting haunts the cultivated regions: he is never far from the corn-fields.

54. The Yellow Bunting, on the contrary, seems far more independent of grain; and I saw it throughout the county wherever there were any bushes or trees.

55. The Reed Bunting is common also near rushy and reedy pools.

1 Error. J. A. H.-B. 
56. The Chaffineh; 57. The Greenfineh; 58. The Bullfineh; 59. The Goldfineh; 60. The Linnet-all common and daily-seen English birds-are everywhere to be found; excepting, indeed, the goldfinch, which bird is far more rare than the others, being seen only about some of the gardens and orchards in the south of the county.

61. The Mountain-fineh, a bird not unlike the female snow-bunting in general appearance, is a frequent [?] visitor.

62. The common House Sparrow, as usual, frequents the labitations of men everywhere as far as Tongue.

63. The Sisken is in almost every wood during the spring and summer; nevertheless its nest is but rarely found.

64. The Redpole is also common: it breeds in the little thickets of birch, etc., by the sides of many of the wild mountain lakes; and in winter may be seen in large flocks feeding on the seeds of the alder and other trees.

65. The Cross Bill has of late years becone numerous in the fir-woods, and will probably become far more so when the magnificent plantations of the Duke of Sutherland grow to a height suited to these amusing birds.

66. The Common Starling is widely distributed. 
The greatest number that I saw in any one place was on the island of Handa.

67. The Goatsueker, an insectivorous bird, although not very frequently seen, is easily recognised by the humming noise it utters, which resembles somewhat the low buzzing of a spinning-wheel.

68. The Cornish Chough, or Red-legged Crow, is rare. It fixes upon the most lofty and steep precipices for its abode. I saw it near Durness. ${ }^{1}$

69. The Raven manages, notwithstanding the constant war waged against him, to keep his ground, and to continue tolerably numerous. I constantly see a pair or more of them playing grotesque antics, and uttering varied and strange cries upon some isolated rock on the mountain side, from which they can have a good view of any approaching eneny. Their chief location is, however, along the seashore, and about the rocky islands, where they can get a good supply of dead fish, seals, etc.

70. The Carrion Crow is rare; but,

71. The Hooded Crow is numerous everywhere, in spite of traps and guns. Wary and strong, they manage to evade all attempts at their extirpation, and to keep up their indiscriminate and wholesale destruction of eggs of every kind. I consider the hooded crow to be the greatest enerny to game, and indeed to all other birds, that we have. I

VOL. I.

1 See $\Lambda_{\text {ppendix, page } 345 .}$ 
have seen a black crow and hooded crow nesting together.

72. The Rook is as common in Sutherland as in any other part of the kingdom, repaying by its destruction of grubs and noxious insects the mischief it does to grain.

73. The Jackdaw is numerous, building both in rocks and chimneys, as its convenience or fancy happens to lead it.

74. The Magpie is a common inhabitant of all the woody districts.

75. That singular little bird the Wryneck has been killed but rarely in Sutherlandshire.

76. The Common Trce-creeper is everywhere in abundance where there is wood.

77. The Cuckoo is in great abundance during the spring and summer, more particularly in the rocky and wild hill-sides, where there are frequent patches of birch and other underwood. I heard it at Tongue, and everywhere to the south of that place.

78. The Kingfisher is a rare but occasional visitor: it does not breed in Sutherlandshire.

79. The Chimney Swallow is common.

80. The Swift, according to its universal habit, wheels and screams as diligently round Dornoch Cathedral and other lofty buildings in Sutherland, 
as it does round the spire of a village church in England.

81. The Sand Martin is numerous wherever the ground suits its habits; and the Common House Martin is also everywhere: it breeds, too, in many of the rocky cliffs and cares of the coast. I particularly observed it in the cave of Smoo, near Durness. ${ }^{1}$

82. The Wood-Pigcon is numerous wherever woods and cultivation united afford it food and shelter. In my opinion the good it does the farmer, in feeding for many months of the year on the seeds of the wild mustard, ragweed, etc. etc., is a fair equivalent for all the grain it consumes. As far north as Tongue I heard and saw this bird.

83. The Rock Dove, a beautiful and interesting little bird, frequents most of the rocky shores of the north coast. Inhabiting the crevices and caverns formed by the constant beating of the waves, and fearless of the surf and swell dashing constantly into its dwelling-places, this bird lives and multiplies; seldom killed by man, but probably affording a great source of food to the peregrine falcons who build in its neighbourhood.

I never saw any kind of woodpecker in Sutherlandshire, though it is most probable that the spotted woodpecker does exist in the old woods near

1 See Appendix, page 345. 
Dunrobin and elsewhere. Indeed I have heard that it has been seen there; but I would rather run the chance of leaving out birds that do occur than insert the name of any bird as being indigenous, unless I had seen it myself, or had heard of its being seen by persons whose authority I could not doubt, either as to their truthfulness or their skill.

I write these pages wholly for the amusement and information of my reader, and take down the names of birds out of my note-book, in which I have inserted them in almost every instance after having seen them myself; and the very few which I have not seen living in Sutherlandshire, Mr. Dunbar has procured in that county, and has them now preserved in his collection.

I must apologise to the scientific ornithologist for any mistakes I may have made in naming the several birds, as I am more of an out-door than an in-door naturalist; and if my notes are of any value, it will be for their truth, and because they are the result of personal observation and acquaintance with the birds. J. will only request, in the words of Horace-

Si quid novisti rectius istis,

Candidus imperti : si non, his utere mecum. 


\section{CHAPTER IX.}

List continued-Game Birds; Destruction of by ShepherdsPlovers-Sandpipers and Snipes, etc.-Water-fowl ; Swans, Geese, varieties of Ducks, Grebes, Terus, Gulls, etc.Decrease of many kinds of birds-Egg Dealers.

THE next class of birds inhabiting Sutherlandshire that I will enumerate are those more immediately coming under the denomination of game.

84. First among which is the Blackcock, certainly the finest game bird of Britain. In the numerous and extensive plantations of the Duke of Sutherland this bird abounds, and extends throughout the county wherever it has the least protection from vermin and shepherds, and wherever there are any patches of wood. I saw several near the shore of Loch Laighal. It is, however, a bird easily destroyed. The shepherds and their boys generally carry guns, under the excuse of shooting foxes (which they never $d o$ ), and in consequence black game and everything that is eatable fall a prey to these men at all seasons of the year, whilst gray crows and other destructive birds pass by unharmed.

85. Grouse, of course, abound only where vermin 
are kept under. In the north and north-west districts of the county, excepting in one or two small districts, grouse are very rare indeed. In Assynt, where a clever keeper and trapper is kept, these birds have increased rapidly within a few years. The Duke of Sutherland, I believe, only preserves that part of the country nearer to Dunrobin, and which is within reach of his friends. Even if all his immense territory were preserved and protected from vermin, etc., a great part of it, from its distance, would be useless as shootingground. No bird is handsomer or more game-like than a cock grouse in the spring-time, as he struts and crows with erect comb on some hillock, scarcely taking notice of the passer-by.

86. The Ptarmigan is tolerably numerous on the more lofty ranges of mountains, such as Ben Hee, Ben Cleebrick, Ben Laighal, and many others, the summits of which this bird frequents, seldom coming down to the heather, but living, a true child of the mist, above all vegetation, amongst the rocks and loose stones. The Ptarmigan requires protection as well as the grouse, more particularly from shepherds and their boys.

87. The Common Pheasant is nowhere very abundant in Sutherland; in the lower districts, near Dunrobin, there are some, but no great 
number, sufficient, however, to make a beautiful variety in the game of the county.

88. Partridges, on the contrary, are very numerous in all the southern range, where the finelycultivated fields, bordering on the young plantations, offer every advantage for their loreeding. I have occasionally seen partridges in very wild parts of Sutherland, where no bird but grouse would be looked for.

89. The Quail appears occasionally near Dunrobin. This bird may be here oftener than is supposed; for, arriving when the wheat is at a sufficient height to conceal it, seldom taking wing, and departing before the crops are well off the ground, its presence can only be known by its peculiar call or whistle.

90. The Landrail, as I have before said, is in every corner of the county where it can find a patch of corn. I heard it at Tongue in great numbers; also at Heilam Ferry in a small patch of oats. The gamekeeper at Tongue told me that he kills it frequently during the winter.

From the landrail one naturally comes to that class of birds which comprise the plovers, etc.

91. The Golden Plover is very numerous in all the higher districts during the breeding season. Its eggs are beautifully marked and very large in 
proportion to the size of the bird. I saw these plovers on all the elevated moors: in winter they collect and descend towards the shores.

92. The Dotterel, a rare bird anywhere, breeds on Cleebrick, but is by no means numerous.

93. The Ring Dotterel is very numerous, breeding near the lakes and streams, and also near the sea-shore: they leave the inland parts of the country entirely on the approach of winter.

94. The Peewit or Lapwing is numerous everywhere from the end of February to the end of October.

95. The Turnstone is only a visitor, not breeding here.

96. The Godwit.

97. The Sanderling.

98. The Knot, and a great variety of waders and sandpipers which, not being thoroughly acquainted with throughout all their changes of plumage, I cannot enumerate, swarm on all the sandy and muddy creeks and bays of the county. It would require many years, and a most accomplished naturalist, to describe accurately all the varieties that are to be found on these coasts. I am confident that, at different times, almost every known kind of shore-bird could be procured.

99. The Oyster-catcher breeds here and re- 
CH. IX.

BIRDS.

mains during the winter, always finding a good supply of food.

100. The Curlew, too, breeds on all the high moors, and takes to the shore in the winter.

101. The Dunlin, and

102. Common Sandpiper, also breed near most of the lakes and streams.

103. The Jack-snipe is said to breed in one or two localities, as is also

104. The Great Snipe (Scolopax major); but I never was quite satisfied with the authenticity of these accounts, particularly as regards the jacksnipe; for the very man whom I was referred to as having seen this bird breeding (Mr. Ross, the keeper at Tongue) distinctly assured me that it never had been seen in that country in the breeding season.

105. The Common Snipe breeds in every locality suited to its habits.

106. The Woodeock, of late years, has commenced breeding also in most of the large woods, laying four large eggs, similar in colour to those of the snipe.

107. The Redshank breeds also very commonly in all marshy parts of the hills.

108. The Greenshank is not so common, but I saw it breeding about Loch Naver, Loch Laighal, and in many other places throughout the county. 
109. The Water-rail is not uncommon in the winter, but from its retired habits is seldom seen: it may perhaps breed in the larger tracts of reeds and rushes, though I have never heard of its nest being found.

110. The Whimbrel breeds in the northern and most retired parts of the country; I saw several on the island of Handa in the month of June. ${ }^{1}$

111. The Hcron is common everywhere, though the only breeding-place that I know of is near Louberoy, on the Oykel river, where these birds breed on an island in a loch situated some two miles from the roadside.

112. The Bittern is rare: but I have heard its cry near Shinness, on Loch Shin.

113. That very pretty and elegant little bird the Red-necked Phalarope is found in the breeding season, but only rarely. I saw a pair close to Loch Naver in the month of June: they evidently had a nest not far from the spot.

The varieties of water-fowl are very numerous, and no doubt the county is visited by nearly every known European species at different seasons.

114. The Common Wild Swan, and

115. Bewick's Swan, are not uncommon during the winter. Their appearance in any of the seaI See Appendix, page 354. 
lochs, such as Loch Erriboll, is considered to foretell severe weather.

116. The Gray Lag Goose breeds in Loch Maddie, Loch Laighal, Loch Urigil, etc.; but I am sorry to see that these fine birds have every chance of being entirely driven away from their haunts.

117. The Bean Goose breeds on Loch Shin. [?]

118. The White-fronted Goose is a winter visitor, and the rarest and handsomest species that frequents this country.

119. The Brent Goose comes to most of the inlets of the sea in immense numbers during the winter: it is one of the best wild-fowl for the table.

120. The Berniele Goose, though an occasional visitor, is much more rare than the last-named species. The brent goose is more frequent on the east coast, while the bernicle keeps to the western side of the county.

121. The Sheldrake breeds very commonly about the sandy parts of the coast.

122. The Pintail, a very beautiful bird, visits this county in the winter.

123. The Common Mallard is everywhere to be found, as is its miniature likeness,

124. The Teal, during the whole year.

125. The Widgeon breeds in a few localities-- 
for instance, near Loch Naver: in the winter it is one of the most numerous of all wild-fowl.

126. The Eider Duck breeds on some islands at the entrance of the Kyle of Tongue.

127. The King Duck is seen in the same district, but only rarely.

128. The Velvct Duck is in abundance during the winter on the east coast.

129. The Common Pochard,

130. The Scaup Duck,

131. The Golden Eye, are all common during the winter; the latter is said to breed here occasionally: I saw a pair about the 15 th of May in Loch Laighal.

132. The long-tailed Duck is very numerous on the east coast during the winter.

133. The Merganser breeds about some of the lakes near Scowrie and elsewhere.

134. The Goosander also is not uncommon.

135. The Sclavonian Grcbc, and

136. The Little Grebe, are permanent inhabitants: the latter is to be found in most localities.

137. The Great Northern Diver frequents the northern parts of the county. I saw this bird near Durness about the 14th of May. The people tell me that it is frequently seen about that coast accompanied by a young one, apparently 
just hatched; its nest, however, has not been found.

138. The Black-throated Diver is gradually diminishing in number, but still breeds in the lakes of Assynt, Loch Laighal, and elsewhere.

139. The Red-throated Diver breeds also in the northern parts of the county.

140. The Foolish Guillemot breeds in countless numbers on the island of Handa and elsewhere.

141. The Black Guillemot is much rarer, but I saw it near the same island in June.

142. The Puffin is also numerous in Handa, etc.; as is

143. The Razor-bill.

144. The Little Auk is a winter and occasional visitor.

145. The Cormorant, and

146. The Shag, breed in many different places along the coast. I saw great numbers of them about Whiten Head, Handa, etc. etc.

147. The Gannet breeds on some rocks off the northern coasts.

Of Terns I have seen the following varieties :-

148. The Rosecte Tern.

149. The Common Tern.

150. The Aretie Tern.

151. The Lesser Tern;

and no doubt there are many other varieties. 
152. The Black-headed Gull breeds on inland lakes in great numbers.

153. The Kittiwake Gull breeds on the rocky cliffs of Handa and elsewhere.

154. The Comnon Gull breeds also in great numbers on the rocky coasts and on different islands.

155. The Greater black-backed Gull, and

156. The Lesscr black-backed Gull, breed in great numbers on different lochs: I particularly observed both kinds on Loch Laighal. No doubt many other species of the sea-gull and skua, besides a great variety of wild-fowl, visit this county at different seasons; but I am determined only to enumerate those that I have seen myself. No part of Britain, or indeed scarcely of Europe, is better adapted for a resting-place for migratory birds on their way to and from their more northern breedingplaces; and the extensive lakes and wilds afford shelter to many that are not generally known to remain in Britain during the summer. The numerous bays and inlets of the sea, leaving at low water great tracts of sand and mud, afford food during the winter for innumerable wild-fowl and waders.

Many of the finer kinds both of land and waterbirds certainly are becoming almost extinct, being hunted down by both gamekeepers and egg-dealers, 
the latter being frequently a set of mercenary and ignorant men, deceived themselves and deceiving others as to the kind of eggrs which they offer for sale; and, instead of furthering the knowledge of natural history, rendering it more obscure by passing off one egg for another, and having recourse to as many tricks as a horse-jockey in selling their specimens, which are often bought by people who have not the slightest knowledge of the natural history of the bird whose eggs they fancy that they are buying.

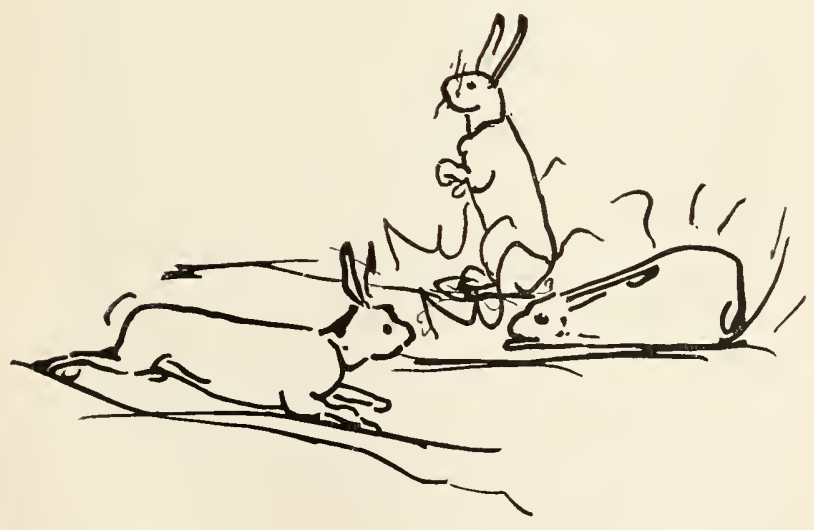




\section{CHAPTER X.}

Deer-Hounds-Deer Forest in Sutherlandshire-Effect of the Forests on Deer-The Stag casting his Horns-Hinds and Calves-Courage of the Hind-Poaching Shepherds-Value of Horns-Fighting of Stags-Highland Forester-Breed of Deer-Hounds.

WhILE staying at the inn at Aultnaharrow, I saw several brace of deer-hounds of the true old Scotch breed. These dogs, which belonged to Lord Ellesmere, were kept close to the inn, at the house of one of his Lordship's foresters. The tract of country preserved as a deer forest comprises a most extensive range of mountains, the best in all Scotland for the purpose. Reaching away to the north-west and west, the forest takes in corrie after corrie, and mountain after mountain, of the most wild and romantic character. Fitted, too, for scarcely any other purpose than as a refuge for wild animals, the most determined utilitarian could not say that the ground was wasted, nor suggest a better use to which to apply it. It is far too barren to make sheep farming remunerative, and any other way of attempting to make the mountains in that district useful to mankind would be labour thrown away. 
In this fine range the red-deer daily increase in number; so much so, that I have no doubt that, unless they are systematically shot down, they will, in the course of some few years, degenerate in size and beauty from the ground being overstocked; for, although there is plenty of room in the surrounding wild mountains for the deer to distribute and disperse themselves, still so much do they dislike being disturbed, and so determinedly do they adhere to the forests where neither sheep nor shepherds annoy them, that while these quiet places are overstocked, the deer are almost wholly drained out of all the surrounding mountains. I speak here only comparatively, for of course red-deer are to be found almost everywhere throughout the county; still, all the sheep-farms have far fewer deer on them than they had before the forest was made, notwithstanding that the number of these animals is probably greater, on the whole, than it was then. Certain slopes and hill-sides, even close to the maiu road, are never without deer, and the passer-by seldom travels many miles without seeing some of these noble animals. They seem used to the sight of people on the road (although so few do travel by it); and on a carriage coming into sight the stag scarcely stops his feeding for a longer time than is sufficient for him to take a good gaze at VOL. I. 
his natural enemy, when he again continues his rapid grazing, although perhaps not much more than a rifle-shot from the roadside. In the middle of the day the deer are seldom to be seen, except by a practised eye, as they are then at rest and lying quietly, with little more than their head and neck above the rough heath. In the early morning or towards evening they feed downwards towards the grassy sides of the rivers and burns. In very hot weather the stags, tormented by midges and flies on the lower grounds, keep on the high mountains and ridges, where they have the advantage of every cool breeze that blows. Hardy as he naturally must be, the stag does not seem to like exposing himself more than is necessary to extremes of heat and cold. In this respect the hinds seem more hardy than their antlered lords. For some time after they lose their horns in the beginning of May the stags seem to feel helpless and unarmed, retiring to out-of-the-way places, where they remain as quiet and stationary as they can, not wandering far from their hiding-place, till their horns having in some measure grown, they feel more able to keep their place amongst their fellows. I have often heard people affirm that they hide their horns invariably on casting them, but this is by no means the case; the horns are constantly 
found; I have frequently picked them up myself, and have seen great numbers that have been found on the hills. A man walking across a rugged and extensive range of mountain cannot expect to find very often an object so little conspicuous as a stag's horn, unless he is a forester or keeper, and as such living amongst the deer at all times. There is no doubt, too, that deer have the habit of chewing and breaking up horns or bones, or any substance of the kind, that they find in their wanderings; in the same manner that cattle in a field will chew for hours together a bone, old bit of leather, or any other hard substance, to the neglect of the clover or grass, or whatever food they may be surrounded by. It is probable, also, that the deer trample under the heather, in the course of their working at it, any horn that comes in their way.

When about to calve, the hinds retire to the most lonely and undisturbed places, where there is little risk of their young meeting with enemies while unable to escape. For a few days they appear to keep them in these safe solitudes, visiting them little during the daytime; but as soon as the calves have acquired a certain degree of strength, they become the inseparable companions of theirmothers. Where the hind is, there is the calf following its dam over hill and dale. At first they are covered with white 
marks, but, losing these, they are of a darkish brown, and are well clothed with long hair by the approach of the winter. Although not coming to full maturity for several years, the growth of young deer is very rapid for the first six or eight months. Did they not acquire strength rather quickly in proportion to their after growth, it would be impossible for them to keep company with the hinds in their numerous flights over mountainous and dangerous passes, impelled onwards by the sight or scent of some enemy real or imaginary. Eagles and foxes both make prey of the newly-born calves; though I am told that the parent will defend her young courageously and effectively against either of these enemies if she happens to be at hand when they are attacked: her manner of defence is by striking with her forefeet-a species of warfare in which the red-deer hind is a most active enemy, and difficult to cope with. I have seen one, when wounded and standing in a burn, raise herself up and lash out with her fore-feet (armed as they are with sharp and hard hoofs) in a manner which made it a service of no slight danger to approach her. Several times did a hind in this manner strike at and knock under water a dog of the most determined courage that I had slipped at her; and equally ready was she to kick out with both her hind-legs at once, so that it was 
by no means safe or easy to get at her ; till at last the dog, after being sadly knocked about, left the water, and sprang upon the deer's back from an overhanging rock, seizing her by the ear and then by the throat in a manner that soon subdued the poor animal. Having more than once seen a hind defend herself most courageously in this manner, I can easily believe the stories that I have been told of their success in defending their young against fox or eagle, notwithstanding the cunning of the former and the almost irresistible swoop of the latter enemy.

Deer, from their size and strength, are secure from the attacks of every other wild animal of the country.

Notwithstanding the vigilance and care of the foresters, who in this county are, I believe, all men of honesty and experience, the shepherds manage to kill many a deer at all seasons; nor is it possible for any number of keepers to prevent this entirely; though they may be as watchful as possible, the shepherd, from being constantly on the hill amongst the deer, and knowing by experience all their haunts at every time of day and at every season, has advantages over the keeper that no vigilance of the latter can counterbalance. A shepherd has for some days, perhaps, observed that a particularly fine stag, with noble head and in good condition, fre- 
quents some certain grassy burm to feed in. There he grazes daily, going thither about four o'clock every evening; and having done so undisturbed several times in succession, he becomes careless, and on leaving the braeside on which he rẹsts throughout the day, he feeds rapidly down the burnside till he arrives at the favourite spot of grass. The shepherd, knowing well that the deer will continue on this feeding-spot until disturbed, watches his opportunity when the forester has taken some other direction, or has not left his home, or, in fact, when the coast is clear: he then takes his gun out of the stock, and easily concealing the two parts till he is safe in the solitudes of the mountain, he betakes himself to some hiding-place within an easy shot, and to leeward of the place which he well knows the stag will visit at the feeding-time. Having looked well to his copper cap or priming, he waits patiently till the animal is within twenty or thirty yards of him, when a handful of slugs or a bullet settles the business. The four quarters are then conveyed home as convenience and opportunity suit. If the antlers are gool, they are another source of profit, there being a ready sale for them to some gun-maker or bird-stuffer, many of whom have constant correspondence with the shepherds, keepers, etc., for the purpose of buying deers' heads, 
birds' eggs, skins, etc., which they resell to visitors at Inverness, or even to sportsmen who, taking the stag's head to England with them, pass it off as a trophy of their own skill and prowess. I have known instances of this kind, although it is difficult to understand how a man can exhibit as his own shooting, and nail up over his hall-door, a stag's head which he has bought for three or four pounds instead of shooting it, without being ashamed to behold such a memento of his own weakness and want of good faith.

In my opinion, the general r'un of the old stags' heads in Sutherlandshire are the handsomest of any in Scotland, in the way the horns are set on the heal and in the shape of the horns themselves. The largest and oldest heads that I have seen in that county form a fine, widely-stretched circle, the tops of the antlers arching inwards towards each other. I never myself saw horns with so fine a spread and arch in any other county, though I do not pretend to say that such may not be seen elsewhere. A nobler sight than a lierd of well-antlered stags standing clearly defined on the horizon, and combined with the surrounding scenery and all the ct cateras of the country which they inhabit, can scarcely be imagined. On the wide grassy plains between Loch Shin and Aultnaharrow, and between 
Ben Hee and Ben Cleebrick, I have generally seen a number of hinds near the roadside ; but the stags, or at any rate the older stags, keep higher up the mountains.

These plains must be excellent ground for running the deer-hounds on, and I wished much that I could have remained long enough in the country to see some of the dogs run a deer; but being summoned at the time to England, I was obliged to depart without even the treat of passing some days in the deer-forest, notwithstanding the Duke of Sutherland's kind permission. Of course I should have gone "unarmed," it being as early as the middle of June; but I am happy to say that (although sportsman enough in my way) I call enjoy watching and making acquaintance with the actions and habits of so fine an animal as the stag quite as much as endeavouring to kill him. Without pretending to disown my love of deerstalking, I find an enjoyment in watching unseen, and patiently, the animals in a manner which one could not do, supposing oneself to be rifle in hand; for then, such is the passion of mankind for the chase, that I fancy few people exist who would not be more intent on killing the stag than in quietly looking at him. In the present instance, however, I had little leisure for even looking at the deer. 
There is a constant succession of fine mountains from Assynt down to near Dunrobin Castle, all frequented more or less by deer; and the gamekeeper at the castle told me that they came down into the woods close to his house, where, from good feeding and quiet, they became very fine and fat, getting into condition very early in the season. I have frequently seen deer late in the evenings fight furiously with their horms, till the noise of their antlers striking against each other sounded far and wide. The two hostile stags meet face to face, and, charging straight at each other like two rams, each endeavoured to turn the flank of the other as if to get a chance of goring him. The weakest, however, seemed always to have a prudent lnowledge of when he was overmatched, and, having leaped quickly aside to avoid being gored, he generally retreated without injury. Sometimes, when equally matched, they fight together in this manner for a long time, making a great rattling with their horns.

Deer-stalking with the Sutherland Highlander seems an almost invincible passion. His constant thoughts and dreams are about the mountain corrie and the stag: get him into conversation on any subject, and by some means it invariably comes round to deer and deer-stalking. He has stories without end, handed down from father to son, of 
wonderful shots, and dogs that never failed to pull down their stag. On most points silent and reserved, on this one he is talkative and eloquent. No man, too, has a greater taste for, and a more correct conception of, the beauties of nature: he points out to you with admiration the very mountain slope, the very corrie that you have already marked down in your mind as surpassingly grand. At first you may think him a reserved and rather morose man, but when he finds out that you are not only a brother of the craft, but also a fervent admirer of the natural beauties of his favourite lochs and corries, his heart opens, and he will go through fire or water to serve you: his expression of face alters, he takes you under his protection, and leads you to points of view which you would have travelled fifty miles to see; and, in fact, enters into all your wishes and thoughts with tact and eager desire to please you. Mercenary and greedy as, I am sorry to say, Highlanders in many parts of the country have become, I did not find this the case in Sutherland. The shootings not having been let much, the country-people are not yet spoiled, but still retain, in a great measure, the natural good feeling, the air of high-bred civility, of which most mountaineers have a far greater 
share than men of the same rank of life brought up in the Lowlands.

Though a Highland deer-stalker may sometimes break loose and have a day's bout at whisky, he is not, generally speaking, at all an intemperate man : two weaknesses he may have-snuff and smoke; the mull, with its spoon of wood or eagle's quill (that not a grain may be lost), and the well-smoked and short clay pipe, are his constant companions. If he misses his stag after a severe stalk, he takes a few whiffs to console himself: if he succeeds, and has his hand already on the prostrate body of the object of his pursuit, the pipe comes into play. The first thing in the morning, while looking from the shealing door to see which way the wind blows, there is the pipe between his teeth : and when returning from his day's work he smokes the pipe of retrospection, while he calls to mind all the different hits and failures of the pursuit. Having reached home, fed himself and dogs, and had his moderate allowance of whisky, twenty to one but he walks out, pipe in mouth, to see which way the clouds are drifting, so as to speculate on the weather of the morrow, or perhaps to listen to the nocturnal cries of the birds and animals of the mountain or loch. You seldom see him fill his pipe; it seems ready charged, always fit for action, and also self- 
extinguishing in some inexplicable manner; as on your asking him a question suddenly when out on the hill, if smoking, ten to one but he puts the pipe, with red-hot tobacco in it, at once into his waistcoat pocket, where it dies a natural death in an innocent manner that I would recommend no one else to expect his pipe to imitate.

Summer or winter the Highland deer-stalker puts on his plaid when going out, and, if he does not carry a gun, has in his hand some favourite stick (or "staff," as he calls it) made of hazel or juniper, and cut during some excursion to the low country. His telescope, though good, generally refuses to be seen distinctly through by any eyes but his own; somehow no one else can hit off the focus. Though caring little for grouse-shooting, he is usually a fisherman, and can throw a fly well enough on occasion, and a present of salmon flies goes straight to his heart.

To return to Aultnaharrow. I was much pleased with the kennel of deer-hounds in charge of the forester there; some of them fine, powerful dogs, fit to pull down any stag. This breed of dogs, which a few years ago was almost extinct, or at any rate only in the hands of a very few Highland proprietors, is now rapidly increasing, not only in numbers, but also in size, strength, and other good 
qualities. The three finest dogs of the kind that I ever saw were at Foyers, on Loch Ness; and I believe that they were equally admired by a gentleman far more fit to judge of them than I am, Mr. Grant of Glenmorriston, who was kind enough to take me to see them. The two young dogs were undoubtedly among the finest of their race, for with the strength of a lion they were made as much for speed, and as compactly put together, as the highestbred greyhound at Newmarket. They had all the points and qualifications of a thorough-bred greyhound, from their head to their round cat-like feet. Indeed I suppose that, owing to neither trouble nor expense having been for some time past spared by many English sportsmen in improving this breed of dogs, the deer-hound is now to be found in as great perfection as ever it was.

Like other greyhounds these dogs do not continue fit for service for more than six years. The violent pace and the strains they are liable to from the nature of the ground they run on, and the strength of the animal they pursue, all combine to make them show symptoms of old age at an earlier time of life than most other hunting dogs. In rearing these dogs it is absolutely necessary that they should have nearly constant liberty, without which they neither come to their full strength nor 
development. At the same time they are sadly inclined to sheep killing and other mischief : most dogs learn this fault at first by being allowed to go about amongst very young lambs, which are invariably tempting objects of pursuit to wild and mischievously-disposed puppies.

I am much inclined to crossing the deer-hound with the mastiff or fox-hound. The former I prefer as giving strength and determination in seizing and holding a stag. This cross, too, imparts to the disposition of the $\operatorname{dog}$ a kind of bloodthirstiness which is invaluable in tracking and pursuing wounded deer, and this is the principal use of all deer-hounds. No forest will bear too frequent coursing; the deer will take themselves off to quieter ground without fail, being far more effectually scared away by the hound than by the rifle.

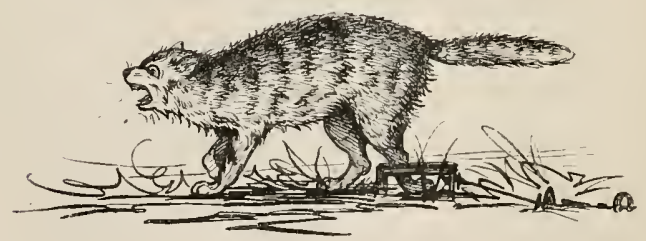




\section{CHAP'TER XI.}

Agriculture in Sutherlandshire-Facilities of reaching the County-Caledonian Canal-Travelling in SutherlandInns, excellent management of-Lairg-T'ongue-Durness -Scowrie-Inchnadamph-Inveran-Conclusion of Sutherlandshire.

I WILL now finish my sketches (hurried and inperfect as they are) of Sutherlandshire by recommending my readers, who may wish for a week's enjoyment, to follow my example and travel round that county; there are few who would not derive much pleasure and amusement by doing so. The agriculturist and improver of land would be interested by seeing the different stages of husbandry in the county, from the perfectly-cultivated farms and cattle of the southern parts, to the rude and primitive method of raising small crops of oats amongst the rocks of the north and north-west, where the ground is turned up by ancient and quaintly-shaped substitutes for spades_ploughing being quite impracticable in many places; at the same time that about Tongue, near as it is to the extreme northern point of Britain, both the mode 
of cultivation and the crops would do credit to many a southern county of England.

The sheep, black cattle, ponies, etc., in many parts of the county, are not to be surpassed in Britain. The naturalist, whether his tastes incline to botany, ornithology, or any other line of this interesting pursuit, will find ample means of enriching his cabinets; while I can safely promise the lover of fine and varied scenery a treat that would repay him for a far more difficult and weary journey.

There are three ways of reaching Inverness from Edinburgh: by the steamers which ply along the east coast; by the Highland road, which passes through the centre of the country; or by Aberdeen : the latter is the least interesting road, as it passes through the bleakest and least beautiful part of Scotland. The Edinburgh and Inverness steamer, the "Duke of Richmond," is comfortably enough arranged, and makes good way through the water, but the number of stoppages at different ports is tiresome to the traveller whose object is to reach the end of his journey. The Highland road has a paucity of public conveyances on it at present, but passes through a fine and characteristic range of country. I have occasionally taken the circuitous route going from Edinburgh to Glasgow, and 
thence up the Caledonian Canal to Inverness; and this is, after all, though apparently rather longer, much the most interesting and the least fatiguing manner of reaching Inverness. Not being exposed to rough water, the passengers by these steamboats are able to enjoy the beauties of the whole route; and they are constant and varied throughout the voyage. Independent of the very great natural beauty of the country through which the canal passes, there is a constant succession of objects of historical and legendary interest: while the captains of the boats are well versed in the history of these localities, and also are most obliging and attentive to all strangers, in pointing out and explaining everything that is worth seeing. The managers and proprietors of these steamers at Glasgow are most ready and obligingly anxious to attend to the comfort and amusement of travellers, and to aid them in their movements in any direction, in the most easy and economical manner. No complaint (if one is ever necessary), made against any of the servants of the company, for neglect of their duty, etc., will pass unheeded by the proprietors. In fact, the tourist can scarcely be in better hands, or take a trip that will repay him better than that by the Caledonian Canal.

From Inverness to Tain or Invergordon the way VOL. I. 
is easy by land or sea. Once there, the traveller in Sutherlandshire has two ways of going through the county-either by hiring a horse and suitable machine, or by travelling by the mail-carriage, a kind of open phaeton, which takes (as well as I remember) several passengers: this vehicle goes twice a wreek northwards, and as often south. I rather prefer the more independent way of hiring a horse, which ought to be done for four or five shillings a day, exclusive of his keep. Although hay is not always to be had, I never failed getting good oats at the inns, and good grass, so that a horse is never at a loss. From Tain or Invergordon the best route to the north of Sutherland is to Ardgye, near Bonar Bridge; a good inn and excellent landlord. From thence to Lairg is eleven miles.

At Lairg is another excellent inn, in a most beautiful situation. Lairg to Aultnaharrow, twentytwo miles; thence to Tongue, seventeen miles; Tongue to Durness, eighteen miles, with a resting-inn at Heilam Ferry, or Loch Erriboll, about half-way.

At Durness I should be content to pass many a day. The inn is one of the best in Sutherland, and the landlady, Mrs. Ross, makes her visitors as comfortable as they can desire; at the same time, 
her charges are as moderate as the most economical traveller could wish. The country round Durness is full of magnificently wild scenery, and the sheltered little sandy bays afford excellent bathing.

Durness, by Rhiconnich, to Scowrie, is about twenty-six miles. Scowrie should be another resting-place: there is much to see, and a good inn. For my own part, I have a most pleasing recollection of Scowrie, and of the hospitality of Mr. M'Ivor (the Duke of Sutherland's manager in that district).

Scowrie to Inchnadamph, by Kyleska Ferry, still takes the traveller through a country every step of which is most splendidly wild and picturesque. Inchnadamph Inn, at the foot of Ben More, and at the head of Loch Assynt, is another good restingplace. Loch Inver, four miles from Inchnadamph, has also an excellent inn, and is well worth going to see. To Inveran Inn, on the Shin river, from Inchnadamph is thirty-two miles; but with two inns on the way, Altnagalcanach and Oykel, at both of which tolerable accommodation may be had. Inveran is a small house, but as cleanly and comfortably kept as any inn in Britain. I never knew an angler on the Shin river who did not say the same of the inn at Inveran; the landlady, in her 
homely "motherly" way, makes her guests so comfortable that they always leave her with regret.

All the inns on the Duke of Sutherland's property (almost without exception) are well kept, cleanly, and moderate in their charges, to a degree that the most suspicious and fastidious cockney traveller can find no fault with; and there is none of that paltry imposition which one meets with so frequently in remote places in other parts of the Highlands, where a stranger is looked upon as fair game for plunder.

My tastes have generally led me to the north and north-west of Sutherland, but there is also much to interest and much to see in the eastern parts of the county. Going by Dornoch and Golspie, both excellent inns, thence along the coast to Brora and Helmsdale, two fishing-colonies, and turning northwards to Bighouse, the traveller can either return by Tongue or by Strathnaver, a beautiful green strath, which takes him to Aultnaharrow.

My description of the different routes is short and imperfect, as I do not pretend to write a "road" or "guide" book; but I simply give this sketch as the result of my own note-book, hoping that it may be of use to any one wishing to see the most interesting county in Britain, and one 
of the least visited. Ross-shire, Inverness-shire, etc., lie more in the way of grouse-shooters and sportsmen, and are consequently more known and written about than Sutherland, although the latter can be travelled through with more ease, comfort, and economy than either of the other named counties.

I must conclude my rambles in Sutherland, but hope that some more able and scientific pen than mine will be found to describe the objects of natural history and of interest in the county, which I have merely glanced at. These notes I now commit to the public with all their errors and imperfections, hoping that the fact of the incidents and remarks contained in them, being the result of the personal and unprejudiced observation of one more skilled in using the rifle than the pen, will induce the reader to excuse their faults, and to look more favourably on my scribbling than any merit of the notes themselves may deserve. 


$$
\text { E }
$$




\section{FIELD-NOTES FOR THE YEAR}





\section{FIELD-NO'TES FOR THE YEAR.}

\section{CHAPTER XII.}

JANUARY.

Wood-pigeons-Feeding of Widgeon and Mallards-Wild-fowl -Water-rail-Wild-duck shooting-Change of colour in Trout.

DuRING the month of January the wood-pigeons commence feeding greedily on the turnips. They do not, in my opinion, dig into the roots with their bills, unless rabbits or rooks have been before them to break the skin of the turnip. In fact the woodpigeon's bill is not at all adapted for cutting into a frozen and unbroken turnip. The crops of those which I kill at this season are full of the leaf of the turnip; and in feeding on these, they appear not to attack the centre or heart of the green leaf, but to eat wholly the thin part of it. The wood-pigeon feeds more particularly on the leaf of the Swedish turnip, as being more succulent.

In the garden I see the titmice searching for, and 
feeding on, the nests and eggs of the common garden spider. The little blue tomtit is of great service to gardeners, as a destroyer of many kinds of insects which would increase to a most injurious extent without the aid of these prying little fellows.

The thrushes begin to sing, and the corn-bunting and yellow-hammer to utter their spring note.

In shooting along the bay and the streams, etc., which run into it, I have been astonished this year (1846) by the numbers of a new visitor to this country, the little auk. This bird, though so rarely seen here, appears to have been driven over this season in great flocks; they are everywhere, and so tame as to be easily knocked down with sticks and stones.

The widgeon and teal have now nearly acquired their full plumage; occasionally I bring home a drake-widgeon in his perfect beauty of feather, but very few of them have entirely put off their sober brown. The mallard has for some time been in high beauty, and is most valuable to the dresser of salmon-flies.

I see the widgeon come regularly now at the ebb of the tide, to feed on the grassy banks which are left uncovered by the receding of the water. They first feed as they swim, round the edges of the small islands and banks; but when the tide begins 
to recede, the birds come out on the banks and graze like geese.

This season the wild-ducks have found out a new kind of food-the remains of the diseased potatoes which have been left in the fields. My attention was first called to their feeding on them by observing that my domesticated wild-ducks had managed to dig well into a heap of half-rotten potatoes, which had been put partly under ground, and then covered over with a good thickness of earth, as being unfit for pigs or any other animal. However, the wildducks had scented them out, and, although well supplied with food, they had dug into the heap in all directions, feeding greedily on the rotten potatoes; in fact, leaving their corn for them. I then found that the wild-ducks from the bay flew every evening to the potato-fields to feed on the roots which had been left; and so fond were they of them, that I often saw the ducks rise from the fields in the middle of the day - in the evening it was always a sure place to get a brace or two. The mallard is very omnivorous at this season: in the crop of one killed were oats, small seed, shrimps, and potatoes, all the produce of his researches during the preceding night.

We find the remains of the little auk everywhere; some I have seen amongst the furze bushes, etc., at the distance of fully four miles from the sea. 
They appeared to have been driven there by the wind, and to have died entangled in such unaccustomed ground. The remains which I found did not appear to have been brought by crows, or any animal of prey.

During the present severe frost I am much amused with the long-tail ducks, who at every flow of the tide swim into the bay, and often some way up the river, uttering their most musical and singular cry, which at a distance resembles the bugle-like note of the wild-swan more than anything else.

As long as there is no collection of floating ice, the bay is very full of birds, and the shores are enlivened with the large flocks of oyster-catchers, red-shanks, and an infinite variety of other waders. The red-shank begins now to utter the peculiar whistle which indicates the return of spring: early as it is, too, the jack-snipes, red-wings, fieldfares, etc., seem to return northwards, as I see great numbers of these and other birds, which had for the last month or two disappeared, having, probably, then gone soutliwards.

The little water-rail seems to be a great wanderer. I find its track, and the bird itself, in the most unlikely places; for instance, I put up one in a dry furze field, and my retriever caught another in a hedge, at some distance from the water: I took the 
latter bird home alive to show to my children. When I took him out of my pocket, in which most unaccustomed situation he had been for two hours, this strange little creature looked about him with the greatest nonchalance possible, showing fight at everything that came near him; and when, after having gratified the curiosity of the children, we turned him loose in a ditch of rumning water, he went away jerking up his tail, and not seeming to hurry himself, or to be in the least disconcerted.

In hard frosts during this month I get a great number of wild-ducks by waiting for an hour (the last hour of light) near some open place in the lochs, or streams, where they come to feed. On my way home from shooting, when I have been in the direction of the swamps, I often do this, and generally succeed in filling my bag with mallards and widgeon.

Just before sunset I take up my position in the midst of two or three furze bushes, within easy shot of where a small stream runs into one of the lakes, keeping the water constantly open. Having given my retriever the biscuit which I always carry for him on these cold days, I light my pipe (the great comfort of the patient wildfowl shooter), and look out towards the bay for the mallards. The bay is nearly half a mile off, 
but I can see the ducks between me and the sky almost as soon as they leave it. At first a solitary pair or two come, quietly and swiftly, probably making their way to some favourite spring farther inland. However, with the help of a cartridge, I bring down a brace from a great height as they pass over; sometimes tumbling on the ice of the loch behind me, they are nearly split in two ; sometimes, when winged, they fall in the rushy stream, and give the retriever no small trouble and cold before he gets them; however, he always succeeds, and having brought the bird and received his reward of ship-biscuit, he lies down again, but with eyes and ears all intent on what is going on. The sea-gull or heron may pass, and he takes no notice of them; but the moment that a wild-duck's quack, or the whistle of his wings, is heard, the dog's ears erect themselves, and he watches my face with a look of most inquiring eagerness. I hear the wildswans "trumpeting" on the sea, but know that they are not very likely to come where I am placed. Presently, however, a brace of teal pitch suddenly, and unexpectedly, within a few yards of me, having flitted in from behind.

I kill the drake, but cannot get a shot at the duck, as she flies low, and the smoke hanging heavily in the calm evening, prevents my seeing her. How- 
ever, all at once the mallards begin to fly from the sea, and for half an hour or less I have to load and fire as fast as I can, as they fly over. I prefer shooting them on the wing, for if I let them pitch in the water, my dog has a swim every time I kill one, and gets lialf-dead with ice and frozen snow.

The mallards generally fly in from the sea rapidly, and at no great height; but it requires some practice to kill them, as their flight is much quicker than it appears, and they require a hard blow to kill them dead. If wounded only, they fly off, and dropping at some distance, I can seldom get them that night, owing to the approaching darkness. Sometimes my retriever marks the direction of a wounded duck and gets it, but generally they are lost, and serve only to feed the foxes, who seem to hunt for maimed birds regularly round the lakes.

Having killed ten mallards and a teal, it becomes too dark to shoot any more, although I still hear their wings as they fly over my head. Besides which, I have nearly three miles to walk; and my keeper, who has also killed two or three, had, before we commenced duck-shooting, sundry animals to carry, the produce of my day's wanderings. We have to walk home, too, there being no road near these lakes. So, after I have refilled my pipe, and the old fellow has recharged his nose with a spoon- 
ful of snuff, we shoulder our game and set off. Eight or ten fat mallards, too, are no slight load over a rough track in the dark, so we keep the sands as far as possible, listening to the different cries of the sand-pipers, curlews, and numerous kinds of wild-fowl who feed on the shallows and sandbanks during the night-time. Occasionally in the moonlight we catch a glimpse of the mallards as they rise from some little stream or ditch which runs into the bay, or we see a rabbit hurrying up at our approach from the sea-weed, which he had been nibbling.

In this way, with very little trouble, and often much nearer home, I can generally reckon on getting some few brace of wild-ducks in the winter; shifting my place of ambush according to the weather, the wind, etc., changes in which cause the birds to take to different feeding-places.

Trout are not nearly so tender a fish as is generally supposed. At the farm-yard here they have two trout, about six inches or more in length, living in the wooden trough out of which the cart-horses drink. They were caught in the river in August, and thronghout all the severe frost have lived, and apparently continued in good condition, although sometimes in passing $I$ have seen the water in the trough so firmly frozen, and the ice apparently reaching so low, that the trout had scarcely room to 
swim. When fresh water is put in they always come to the place where it is poured, and seem to look for any particles of food or any insects that may come in with it. They feed on worms which the boys often bring them, and which they take immediately, withont fear. The change of colour in fish is very remarkable, and takes place with great rapidity. Put a living black burn trout into a white basin of water, and it becomes, within half an hour, ${ }^{1}$ of a light colour. Keep the fish living in a white jar for some days, and it becomes absolutely white; but put it into a dark-coloured or black vessel, and although on first being placed there the white-coloured fish shows most conspicuously on the black ground, in a quarter of an hour it becomes as dark-coloured as the bottom of the jar, and consequently difficult to be seen. No doubt this facility of adapting its colour to the bottom of the water in which it lives is of the greatest service to the fish in protecting it from its numerous enemies. All anglers must have observed that in every stream the trout are very much of the same colour as the gravel or sand on which they live: whether this change of colour is a voluntary or involuntary act on the part of the fish I leave it for the scientific to determine.

${ }^{1}$ In the case of some fish the change is perceptible in five minutes.

VOL. I. 
FEB.

\section{CHAPTER XIII.}

\section{FEBRUARY.}

Change of colour in Stoats-Affection of Otters for their young -Roe-hunting-Attachment of Birds to their Mates-Food of Fieldfares during Snow - Widgeon-Wild-fowl shooting at Spynie--Incidents in shooting-Winged Swan-Cats-Food of Wild-geese-Brent Goose.

February 2d.-February is always with us the most snowy month of the year. I find that, in my journal for the first week of this month, during several years, it is generally marked down that the country is clothed in snow. The quantity of floating snow and ice which comes down the river fills the bay, and sends the wild-fowl to some less dreary part of the country. Occasionally a golden eye or long-tailed duck pitches in some clear spot of the river, but is almost immediately driven out again by the floating ice. In some places the course of the river is quite altered, being choked up by the accumulation of ice on the shallows, and the water takes some new run. What becomes of the fish during this kind of weather?

The rooks dig deep into the snow, and plough 
FEB.

up the young wheat in great quantities with their strong bills. The stoats are now pure white in almost every instance, although I shot one on the $3 \mathrm{~d}$ of this month who had only very partially acquired his winter colour. My rabbit beagles ran him for a long time full cry on sone rough ground. Whenever the stoat went into a rabbit-hole I turned him out again with a ferret, in this way running him till I killed him.

While the river is in this state of confusion witl ice, etc., I see that the otter's take themselves to the unfrozen ditches and springs to hunt for eels and flounders, which fish they feed on apparently with great perseverance, if one can judge by the distance they hunt for them in the snow. The otter, judging from the ground he goes over, must commence moving as soon as it is dark, and continue his hunting till nearly daylight.

Notwithstanding the shyness of the otter, this animal is very determined in the defence of its young ones, and boldly confronts a person who takes one of them up. My keeper tells me that he has seen an old otter feeding her young with fish : the two young ones were sitting on a flat stone at the edge of the burn when their parent brought them a good-sized trout. They immediately both seized the fish, pulling and tearing at it like two 
bull-dog puppies. At last they came to a pitched battle with each other, biting, squealing, and tugging, and leaving the trout to its fate. On this the old one interfered, and making them quiet, gave the trout to one of them as his own. The other young one, on seeing the parent do this, no longer interfered, but sat quietly looking on, till the old otter (who in the meantime had renewed her fishing) came back with a large trout for it also.

When she brings a fish to the shore for her young ones, she calls them by a kind of loud whistling cry. Altogether this is a most interesting animal, graceful in its movements, and in salmon rivers not nearly so destructive and injurious as he is supposed to be, feeding on eels, flounders, and trout far more than on salmon: in such situations he is most unjustly persecuted.

The roe now are in perfect condition, and I find the snow does not in the least spoil the scent in hunting them with beagles. It is a very amusing kind of shooting where the woods are sufficiently broken and interspersed with open ground, so as to enable one to see both roe and hounds pretty often. In drawing the large woods I am often annoyed by the hounds going off after a fox, who generally leads them straight away for several miles, tires the little beagles out, and finally escapes into his earth with- 
out getting shot: but occasionally he pays for his depredations, notwithstanding his cunning.

Soon after throwing off in one of the large covers near the sea, the hounds begin to find the cold scent of roe, and gradually working up to the thickets, often start the animal in view. Away they then go, making the woods echo again with their deep tones, the younger dogs taking the lead. The roe at first tries to avoid leaving the first division of wood in which he is found, but on the hounds sticking to him, he crosses some wide open heather and swamp to the higher grounds. Here the trees are older, with little underwood; so after a rattling run through all this, I can reckon on their crossing the swamps again to the thickets, where the buck was first found. He comes to the head of the brae and stands listening to the hounds, carefully examining the wide flats of heath, wood, and swamp below him. The hounds come nearer and nearer, and still the buck seems unwilling to cross the open ground. At last the dogs are close to him, and then only he descends the bank, springing over the juniper, which is frequently six feet high, the staunch little pack threading their way through it. Across they go, and over the swamps, the buck springing from hillock to hillock wherever he can find footing. The beagles make their way 
wonderfully, often in view, but as often tumbling into the holes of water which they sometimes can scarcely get out of; however, I am generally at hand to help them, and once again on terra firma, off they go headed by old "Durwood," who begins now to think of killing. Straight through the thicket where we first found, across a wide tract of smaller and more open wood, they run without a moment's check, startling the blackcocks, who, rising as the hounds pass, perch on the summits of the fir-trees, looking down with wonder at what is going on. Away goes the roe, not fifty yards ahead of his persevering little followers, and they are now all in a wide tract of fir-wood, with the rankest heather in it that I ever saw: straight through this they go to the very sea-shore, putting up the curlews as they skirt the sands. But it is of no use; the beagles become more eager every moment, and after half an hour's hard running round this tract near the shore, the buck seems suddenly to change his mind, and turns directly inland again, at a sharp angle to his course. A short, but very short check ensues; the hounds are soon in full cry again, and after pressing him hard through the cover, he is driven to some sandy hillocks in the midst of the wilderness - and here comes the trial of the hounds. $\mathrm{Up}$ and down, and round and round every one of 
these does the roe go at a foot's pace, but managing to keep always out of view; by this he recovers wind; and, going slowly over the dry sand, leaves as little scent as possible.

It won't do, however: the beagles, headed by the old dog, stick to his track, and wind in and out the hillocks after him, keeping the scent in a manner that is quite incredible. Away goes the buck again to try a new scheme. He suddenly dashes across a wide opening and gets to some high close furze: through this he winds his way, followed, however, by the relentless hounds, who, regardless of rabbits, etc., stick to his scent, although it is getting colder and colder. The evening is coming on, and the frost is becoming severer. The rabbits, too, help to put the dogs out. But the roe is viewed as he passes out of the furze, and we run him over some high hillocks which have great clumps of furze on them. Here again we suddenly come to a check; but, after searching some time in vain for his track or scent, I unexpectedly find his footmark in a deep dry drain which divides the pasturage from the wooded wilderness. There is no mistaking it. So I call the dogs, who, tired and stiff as they are, come joyfully to the holloa. At first they only sniff in an uncertain manner up the drain; but at last the youngest hound gives 
tongue at a spot where some grass or heather had retained the scent longer than elsewhere, and they are all soon again in full cry. I still keep with the hounds to help and encourage them, when presently I hear a shot, and rightly guess that my friend, whom I had left shivering long ago in a pass, had killed the roe. He turned out to be a fine buck; so after paunching him, and rewarding the dogs with blood and liver, etc. etc., which they wait patiently for, not attempting to tear the animal itself, we get it conveyed to the place where I lad left my car.

Passing through a wood on our way, the old hound, who was not coupled, suddenly threw up his nose, and before I could prevent him was off in full cry into the cover. I managed to stop the rest of the dogs, not wishing them to have any more running, as they were all tired out, and went alone to get back Durwood. From his tone I soon knew that it was a fox he was after, as when hunting this animal his cry was always different from what it was when on the scent of a roe. I found it of no use going through the cover; so I waited in the wide road towards which he seemed coming. Presently, quick as lightning, and without the slightest noise, a very large dog-fox sprang into the road. He snuffed the air right and left with an eager look, 
FEB.

but seemed not to observe me, for I was standing quite still close to the trunk of a birch-tree. He then listened to the hound; and finding that he was going eastward, the fox came trotting up the road directly towards me. When within about eighty yards he suddenly stopped, and seemed to suspect my presence. I had had my gun up to my shoulder for some time; and the moment he stopped I pulled the trigger, trusting to a B. B. cartridge, notwithstanding the distance. He immediately began tumbling about, dancing on his head, and springing into the air. I ran up to give him the contents of the other barrel, which was loaded with small shot, but he had disappeared; howerer, with the help of the hound, who had now come up, I found him within twenty yards of the road. He was shot in the chest, and was in the very act of giving up the ghost when we came to him. In this country all ways of killing foxes are considered fair, as hunting is out of the question; and if they are not kept down they destroy every kind of game, lambs, and poultry. Feb. 8.- I shot a female pochard to-day, one out of a large flock: the rest, of course, all flew away. But presently a male bird, probably the mate of the one I had killed, came flying back from the lake to which the flock had gone, and after passing once or twice low over the place where I had shot her, he 
pitched on the water and swam about, searching eagerly for his lost companion. He then went off to the flock again; but soon returned a second time to look for the hen. Three times did he go and return in the same manner, till at last he seemed to give it up as hopeless.

I have observed the same attachment to their mates in common wild-ducks, teal, swans, etc., as well as in many other birds. I remember an instance of a hen grouse being caught by the leg in a common vermin trap which had been set for ravens. It happened that the trap was not looked at till late the following day, when we found that the cock grouse had brought and laid close to his unfortunate mate a quantity of young heather shoots: they were enough to have nearly filled a hat, and the poor bird must have been employed many hours in collecting them. I cannot express how grieved I was at the hen having been caught.

Great numbers of fieldfares come down during the snowy weather to the fields to feed on the turnips. They dig holes into the roots to an extent that astonished me. I shot two or three. They are very fat; but smell and taste so very strongly of turnips that they are quite uneatable.

The widgeons leave the bay, which is nearly covered with ice, and feed on the clover-fields, 
digging under the snow with their bills to get at the herbage. I never saw them do so before in this county; indeed it is very seldom that the snow in Morayshire remains long enough on the ground, at least in the district near the sea, to annoy the wild-fowl to any extent.

While the snow is soft and newly fallen, the rabbits seldom go fifty yards from their seat of the day before, and constantly return to the same bush.

About the middle of this month I was shooting, with Captain Cumming, at the Loch of Spynie, which I considered to be about the best loch in the North for wild-fowl shooting. Its situation is excellent; and being for the most part shallow, and covered with grass, rushes, and tall reeds, it is perfectly adapted in every way for sheltering and feeding all sorts of wild-fowl ; they resort there in incredible numbers, and of every kind, from the swan to the teal. When, in the evening, we took up position near the old potato-fields, we generally killed several mallards, as they feed constantly on these roots.

The widgeon in this loch are remarkably fine, and seem to come early into good plumage. There would appear to be a great proportion of drakes in the flocks of these birds, as, out of ten widgeon killed there was only one duck. The flight of 
widgeon in the evening, as they leave the deeper parts of the lake for the grassy margin, is very amusing. When they first rise, and before we can see them, we hear their peculiar whistle; and they almost immediately appear flying in small companies with great swiftness to their destination. This whistling sound, which they utter during their flight, is quite different from their cry while swimming and playing on the water. It requires a very quick eye and a good retriever to bag many birds in this twilight shooting; but Captain Cumming, alone, killed fourteen mallards and a widgeon one evening while I was there. This was excellent work, considering that it was only for a short time during the dusk that he could shoot, that they were all single shots, and that every bird had to be retrieved out of water overgrown with rushes, etc. The widgeon have already begun to fly in pairs.

In the middle of February the peewits begin to appear here. The exact day depends chiefly on the state of the weather: the first break up of the snow and ice generally brings them. About the same time I hear the coo of the wood-pigeons, who now come near the house for protection. This they do every year as the breeding season approaches.

Three otters are frequenting the mouth of the river, apparently fishing for the flounders left in 
FEB.

the pools near the sea. The keeper is pretty sure of catching them by putting traps at the places where they leave the water on their way up the stream after fishing. Whilst going down the otter seldom leaves the water at all; but unintermittingly fishes his way to the sea : coming up, he takes the land at all the rapids and strong streams. Two rather singular and yet similar things happened to me one day whilst I was wild-fowl shooting. I shot at a mallard, a considerable distance from me, and evidently struck him, as, after flying some distance to the windward, he pitched in a grass field: but, on my approach, he rose again and went at a great height down wind towards the sea. I happened to keep my glass on him, and when he was about a quarter of a mile off I saw him turn over in the air and fall. On coming up to the place I found the bird quite alive, but with his wing broken close to the body. The shot must have struck the bone without breaking it. The singular part of the affair was that the bird could battle against strong wind for at least a quarter of a mile without the injured bone giving way. In the evening we went to wait at a pool for ducks. Just as it got dark a rushing noise was heard, and a pair of swans skimmed rapidly over the old keeper's head, and pitched in the water, making a monstrous wave. 
They did not see us, and immediately began to feed. It was getting dark, and the old man, not wishing to lose a chance, got up from his hidingplace and ran quickly to the water's edge, firing both barrels at the largest bird as it flew away. His gun was only loaded with No. 3, and the distance, as we afterwards found, was above forty yards. Both the swans flew on for some distance, until we suddenly saw the wing of one give way, and down came the bird into the pool, which was of considerable size, although shallow. I had left nuy retriever at home to rest, and before I could stop him, in went the old man, and then began a cliase which I have seldom seen equalled. Although the water was shallow, the bottom was uneven; and every minute down went Donald head foremost. I called to him to let me shoot the bird, and leave it to drift to the shore; but all in vain. On he went, tumbling over and over, and the swan swimming and struggling in the water close to him, making an immense splashing and noise. They got quite away from me; and I had nothing left but to sit down and watch the chase as well as I could through the approaching darkness. At last he hemmed the bird into a rushy corner of the loch, and caught her. But this was no sooner done, than the swan, by her flapping and struggling, tripped 
FEB.

him up; and got away again, leaving her antagonist flat in the water. Then, and not till then, he began to load his gun, which he had to my great wonderment contrived to carry all the time high over his head; but, of course, notwithstanding all his care, it had got quite wet and would not go off, and the conflict ended at last by a lucky blow from the barrels which stunned the swan. I was amused at the boyish eagerness of so old a stager ; particularly as we never lost a shot at ducks or anything else without his laying it to my fault. I " had lifted my head too high," or done something else, showing my want of tact. The poor fellow was in a sad plight, being ducked to the skin all over with half frozen water. However, I made him walk quickly home, and he got no damage from his exploit. The swan weighed 18 lbs., and measured above seven feet from tip to tip. We found that many shots had struck the wing feathers without breaking them.

Towards the end of February, whenever the ground is soft, the badgers leave their holes, and wander far and near, digging up the ground like pigs, in the fields as well as in the woods.

The wild-cats are brindled gray, and I have observed that domestic cats of the same colour are more inclined to take to the woods and hunt for 
themselves than any others. When they do so they invariably grow very large, and are most destructive to game of all kinds. A large cat, of this colour, found out some tame rabbits belonging to my boys, and killed several of them. At last we saw him come out of a hole where some white rabbits were breeding; and he was shot. The brute had evidently been living on them for some time.

At thisseason the bean goose and the pink-footed goose feed very much on a coarse red-coloured grass which grows in the peat-mosses. They pull it up and eat the root, which is somewhat bulbous sliaped. While feeding on it they become very heavy and fat, and have no strong or disagreeable flavour.

Though these two kinds of geese both feed and fly together, still while on wing and while on the ground they keep somewhat apart. The bean geese are far the most numerous; but there is generally a small company of the pink-footed kind with them, and no one but a close observer would perceive that they do not associate as closely as if they all belonged to one family.

A wounded brent goose, which I brought home, very soon became tame, and fed fearlessly close to us; indeed, I have frequently observed the same inclination to tameness in this beautiful kind of goose. 



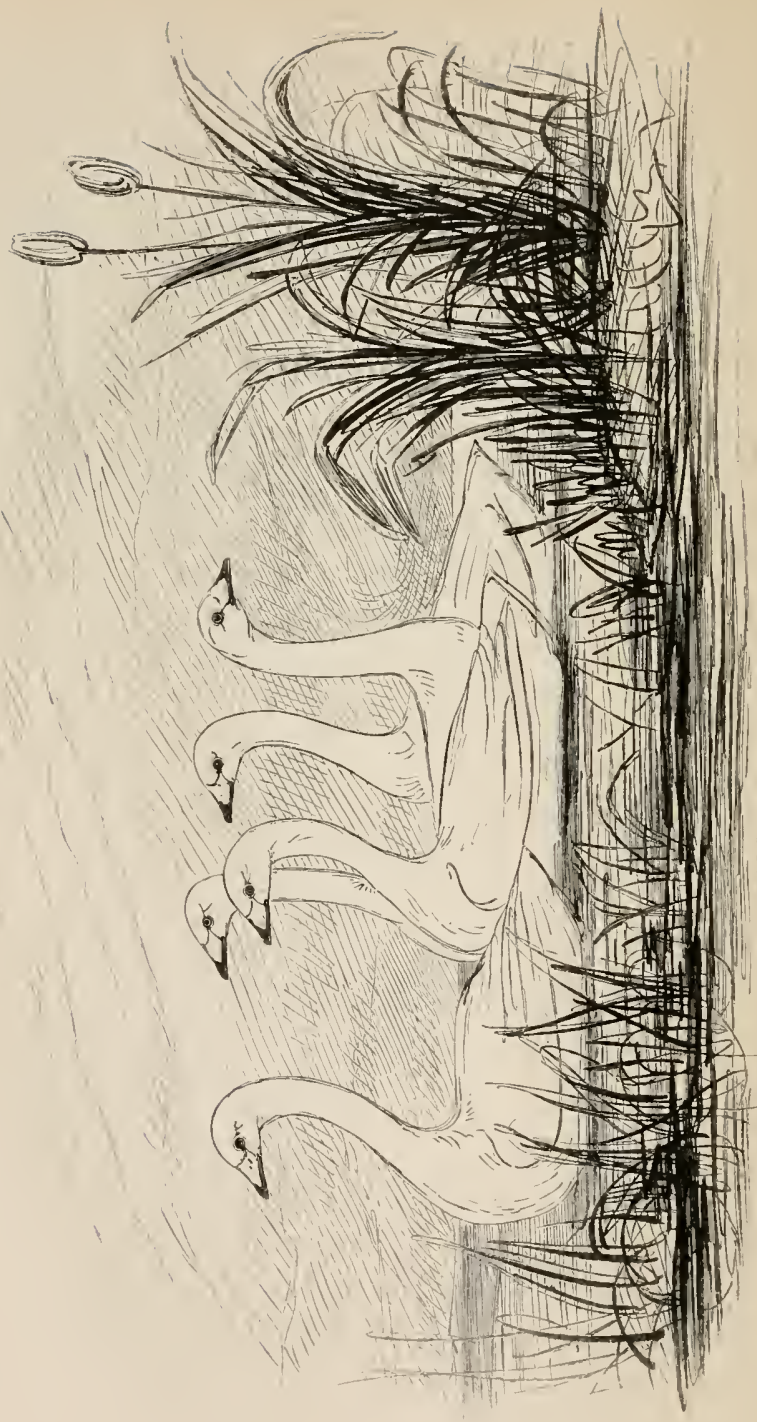

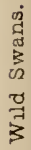

க்
-
$\dot{2}$
$\dot{0}$
$\dot{0}$ 


\title{
CHAPTER XIV.
}

\author{
MARCH.
}

Wild-swans-Loch of Spynie; Wild-fowl on it-Pochard-

Carrion Crows - Death of Wild-swan-Domestication of Wild-fowl; flavour of-Arrival of Geese.

Every day now shows the approach of spring. The mallards are in pairs in all the pools near the lakes, taking to the larger sheets of water only during the daytime. My boys catch plenty of sea-trout in the river; these fish rise better in the month of March than at any other time. I have seen for some time six wild-swans on one of the lakes; they appear to be of two different kinds, three of them being much larger than the others. The larger birds, too, are much more wary and wild than the smaller; at the head of them all is the largest swan I ever saw.

The swans frequent one particular lake, seldom alighting on any other piece of water. This lake is peculiarly open, and very difficult of approach, which is doubtless one reason for their fixing on it; another is, that in many places it is so shallow that they can reach with their long necks the grassy VOL. I. 
plants growing at the bottom, on the roots of which plants they feed. Whenever I go that way there are these swans surrounded by numbers of ducks, widgeon, teal, etc., who are feeding with them and looking out for the scraps and remnants of the plants which they pull up.

Day by day, at the beginning of March, the brent geese seem to increase in numbers: they feed on the grassy banks on the shores of the neck of land called the "Bar."

I drove over to Gordonston to shoot ducks on Spynie. Although the lochs were crowded with birds the day was too fine and calm to enable me to kill many. However, I managed to shoot a few mallards and teal by rowing along and quietly in and out the tall reeds which grow in patches on the lake. The teal are now very lively, flying constantly in small companies and keeping up a perpetual whistling. The coots are always conspicuous amongst the other wild-fowl, swimming high in the water and moving quickly about. On the islands I found several otter seats in the rushes, where they appear to make forms like hares.

The keeper caught a beautiful male pochard which had been wounded somewhere in the body, but apparently was not much hurt, although disabled from flying. I took it home with me alive, 
and turned it into a small enclosure, where it amused us much by its tameness and confidence, beginning to eat worms and porridge immediately, and seeming to enjoy itself in this new situation as much as if it had been always accustomed to it.

There are no enemies so destructive to the wildfowl as the carrion or rather the hooded crow, which is the kind we have here. Eggs and young birds all come alike to these robbers, but the keeper at Spynie manages to kill great numbers of them by poison; he uses strychnia, a very small quantity of which kills the crow on the spot.

The balgers hunt more and more every day at this season if the weather is open, and apparently they wander several miles from their home.

On the $2 d$ of March I see the rooks building. There is much snow on the mountains, but the low country is quite clear.

The principal wild-fowl on Loch Spynie, Loch Lee, etc., just now, are mallards, sheldrakes, widgeons, teals, pintails, scaup ducks, pochards, golden eyes, a few swans, bald coots and waterhens, besides an infinity of gulls, redshanks, plovers, peewits, curlews, etc. They all keep up a constant calling and noise, in the morning and evening particularly. All the ducks, though collected in flocks, still keep in pairs, so that when a large flock is on 
wing, it seems to consist wholly of different pairs of birds.

I have tried two or three days to get at the largest wild-swan on Loch Lee, but without success ; my fruitless attempts I do not mark down - Horas non numero nisi serenas. However, on the 6th, a fine sunny day, as I passed at some distance from the lake where the swans were feeding, they rose and alighted on the largest of the pieces of water; seeing this, and that they were not inclined to take to the sea immediately, I sent the boy who was with me round the lake where they were, while I made my preparations for receiving them at their feeding lake, supposing that they would return to it if allowed to rest for an hour or so and then quietly moved; even if they did not alight,I knew that I was pretty sure of their line of flight to the sea, and they seldom flew very high. I waded across part of the loch to an island, where I determined to await them, and set to work to make up a hiding-place of long heather, etc. This done, I loaded my gun with large shot and cartridges, and established myself behind my barricade. With my glass I saw the boy and retriever go round towards them; the appearance of the swans floating quietly on the water was most picturesque, their white forms being clearly defined on 
the dark blue water, and their shadows almost as distinct as themselves. They all held their heads erect, watching the boy, who, as he had been instructed, walked to and fro opposite the birds and sufficiently near to put them up, but without appearing to be in pursuit of them. I hoped by this means to drive them over to the loch where I was concealed without frightening them so much as to make them take off to the sea; but they seemed so unwilling to rise, and so little afraid of the boy, whom they appeared to look at with curiosity rather than alarm, that I struck a light in order to smoke the pipe of patience and resignation, for, fine as the day was for March, my situation in a damp island and wet through above my knees began to be uncomfortable.

The latakia was not half puffed away when I heard the well-known warning cry of the swans, and immediately looking round saw them just flapping along the water preparatory to their flight. Cocking my gun, and holding the pipe tighter in my teeth, I waited anxiously to see in what direction they would fly. At first they made straight eastward, as if off for the bay of Findhorn, but after a short flight in that direction they turned, and I saw them coming three and three together, as usual, straight towards where I was concealed. In a few 
minutes they were exactly over my head, at a good height, but still within shot, flying with their long necks stretched straight out and their black feet tucked up, but plainly visible as they passed over me. I stood up and took a deliberate aim at the largest of them as he ascended higher into the air at my unexpected appearance. The first barrel seemed to have little effect on him, though I distinctly heard the shot rattle on his strong quills; the second, however, which was loaded with larger shot, was more effective: whilst his two companions continued crying to each other, he remained silent. However, he kept up with the rest, and they all went off towards the bay. In the meantime three smaller swans came within twenty yards of me or less, trumpeting and calling loudly.

With the glass I watched the bird I had fired at, as I knew he was hard hit. He still, however, held his way with the rest, and they were gradually getting indistinct, when I suddenly saw him rise straight up into the air, his snowy plumage shining as it canght the rays of the sun. I saw him a second time rise perpendicularly to a great height; he then suddenly turned backwards in the air and tumbled headlong to the ground perfectly dead. He was above half a mile or more from me, in the direction of the bay, and the whole intervening 
ground was covered with sandhills andi bent, so that I could not see the exact spot where he fell, whether on the dry ground or in the sea. However, I marked the direction as well as I could, and set off after him.

Large as he was, I had a long and for some time a fruitless search amongst the broken sandhills. I scanned the bay with the glass in vain, and then came back towards the lochs. At last I hit upon him by finding a quantity of blood on the sand, and following the drops, which had fallen almost in a stream: in fact the track of blood, though falling from such a height, was as conspicuous as that of a womded hare on snow. At length I came to the swan, who was lying stretched out on the sand, and a noble bird he was. I shouldered him as well as his great length would enable me to do, and carried him back to where the boy was waiting for me. I found him, too, no slight burden; he weighed above $27 \mathrm{lbs}$; the breadth between his wings 8 feet, and his length 5 feet. Of all the swans I ever killed he was by far the largest, the usual weight being from 15 to 18 lbs.

The pochard which I brought home from Spynie remains quite contented and goes about with the other ducks. He will eat whatever they feed upon, but prefers worms to everything else, showing great 
activity in diving for them when they are flung into the water. If they are given to him on land, he usually carries each worm to the water before eating it. Even when brought into the house he seems quite at home. Many kinds of wild-fowl might, with a little care, be perfectly domesticated, and I have no doubt would breed freely. Care must, however, be taken to prevent their flying away at the migrating seasons, and also to keep them at home when they begin to make their nests, as at that time they seem inclined to wander off in search of quiet and undisturbed places. I have no doubt that the sheldrake might be tamed in this way, and after a few generations of them had been bred at home, that these birds would become as useful for the table as our common ducks, and would be far more ornamental.

After two or three generations of any bird have been domesticated, the young ones lose all their wild inclinations, tameness becoming hereditary with them, as skill and the power of benefiting by education become hereditary in dogs to a very striking degree.

Though the flesh of the wild sheldrake is quite unfit to eat, being excessively rank and fishy, the birds, if domesticated and fed on proper food, would soon lose this strong flavour. The common 
mallard, though so excellent a bird when feeding in the stubble-fields, is often rank and bad when driven by deep snows and frost to feed on seaweed, shellfish, etc. Widgeon and brent geese also, and in fact all wild-fowl, are good or bad eating according to where they feed, in the same way that the dog of the Chinese, which is fatted for the table, must be very unlike in flavour to a foxhound who has been fed on horseflesh.

The bernacle goose seldom pays us a visit, but I saw a few one day near the bar. I had one of my boys with me, who was anxious to get a shot at a wild-swan who was swimming about one of the lochs, and when we came back from an unsuccessful pursuit of him the geese had left the place. This bird is numerous only on the west coast.

About the 20th of March I see a few whitefronted geese feeding in the swamps near the lakes.

On the 22d the dabchicks come to their breeding places in the smaller lochs, where there are plenty of rushes, and the sheldrakes now come frequently inland. About the middle of March the black-backed gulls are very noisy in the bay.

As the old keeper saw some bean geese pass over the house, I took a long walk on the 12 th to look for them in their usual feeding-places, but without success. The old man, a true "laudator temporis 
acti," complains that the whole country is spoilt by "drainings and improvements," which banish the wild-fowl from their former haunts.

When the frogs begin to croak in the pools and ditches the mallards are sure to be found in these places every evening and morning.

23d.-Nune avis in ramo tecta laremque parat. The wood-pigeons are building in the shrubberies close to the window.

How beautifully the different birds are constructed for their different modes of feeding! The tender nerves at the end of the bills of the woodcock, snipe, and curlew, enable them to find their food under ground as correctly as if it were within full view. The oyster-catcher can detach from the rock and break up mussels and other shellfish. The oyster-catcher, by the by, can have little to do with oysters except in name, for strong as he is, he could scarcely manage to find his living if condemned to feed on oysters alone. The bill of the merganser and other birds of that kind is perfectly adapted, by means of its curved teeth, to hold their slippery prey, while the inward sloping plates in the wild-duck's bill are equally suited for retaining the small worms, etc., on which they feed. The carrion-feeding ravens and other birds of that class have a most perfect and powerful weapon in 
their strong and sharp bills. The crossbill, too, shears off the fir-cones and extracts the seeds with his clumsy-looking bill with a facility that no other shaped tool would afford him. In short, go through the list of all birds, and you will find that each one is perfectly adapted in form and powers for procuring its peculiar food.

Whilst talking of the food of birds I cannot help adverting to the absurd idea of woodcocks and snipes living "by suction," which you see gravely affirmed as a fact; whereas a snipe or woodcock is as great an eater as any bird I know. Any one who has kept either of these birds in confinement well knows what difficulty he has had in supplying them with sufficient worms tosatisfy their ravenous appetite. My friend Mr. Hancock tells me that he has succeeded in keeping many kinds of sandpipers, and even the common snipe, alive and in good health by feeding them principally on boiled liver minced small, which seems to approximate more closely to the usual food of insectivorous and worm-eating birds, than any other substance.

It is amusing to see the arrival of the larger flocks of geese about this time of year. A few small companies of pink-footed and white-fronted geese usually arrive early in the montll, but about the 28 th, and generally on some quiet evening, im- 
mense flights of the bean goose arrive in the Findhorn Bay. They come in, just about sunset, in four or five large flocks, and an infinite quantity of gabbling and chattering takes place for several hours; but by daybreak they seem to have determined on their respective beats, and separating into smaller flocks disperse over the land, and do not collect again in very numerous flocks until they are about to leave that part of the country at the end of April or the beginning of May. The wildgeese decrease in number every year: the gray lag goose is a very rare visitor to the oat-fields here, although so many breed in Sutherlandshire.

The woodcocks are more numerous at this time of year in the larger woods than during any part of the winter: they pair early, and have probably before this time taken up their breeding quarters. Those which breed abroad do not leave this country till just before their time of laying. I am much inclined to think that most birds which migrate from us in the spring pair some time before they take their departure. 


\section{CHAPTER XV.}

APRIL.

Field-mice-Brent Geese-Arrival of Migratory Birds-In. stinct of Crows in Feeding-Instinct of Thrushes-Disappointments in Shooting Wild-geese-Death of White-fronted Geese-Shetland Pony-Heronry-Anecdote of RoebuckWild-duck's Nest.

THE wild-geese which came a few days ago have now entirely disappeared, either in consequence of finding no oats sown, or from some impending change of weather on the higher grounds.

The field-mice on the approach of cold and wet shut up the mouths of their holes. There are a great many of these little animals in some of the fields near the house, notwithstanding the quantity killed by the owls, who come down from the large woods every night, and hunt in the cultivated grounds.

Immense numbers of brent geese float with every tide into the bays formed by the bar. As the tide recedes they land on the grass and feed in closelypacked flocks. On the land they are light active birds, walking quickly, and with a graceful carriage. On any alarm, before rising, they run together as close as they can; thus affording a good chance to 
the shooter, who may be concealed near enough, of making his shot tell among their heads and necks. All geese and swans have this habit of crowding together when first alarmed.

April is an interesting month to the ornithologist, as it is then that most of the migratory birds change their quarters, some leaving us, and others arriving. The regularity of their going and coming is very surprising. Unless change of weather or very severe winds interfere, the arrival and departure of most birds may be calculated nearly to a day.

For the last two years I have first seen the martins on the 25th of April, and the common chimney swallow on the 27 th. The terns also come at the same time. Indeed in both years I have seen them on the same day, i.e. the 27 th. On the 30 th the fieldfares still remain, but not in the same numbers as they were a few days ago. On the 28th large flocks both of fieldfares and redwings passed by us on their way to the northward. A few pairs of these birds breed, I am told, in the large woods near the Spey. And this year (1848) I was shown a nest and eggs, brought from that district by a brother of Mr. Dunbar. He described it as having been placed near the ground.

Mr. Hancock tells me that in Norway, where he has seen them breeding, the fieldfares make their 
nests in very large companies, a great many being placed on each tree, and for the most part at a considerable height from the ground.

The last jack-snipe that I killed this year was on the 18 th of April. Indeed I do not remember ever killing one after that time. I shot a greenshank on the same day. The latter bird breeds commonly in Sutherlandshire. But I have never ascertained that the jack-snipe's nest was seen, or indeed that the bird is known to breed, in that county. The widgeons begin to decrease in numbers. I do not understand the moulting of these birds : for at the very time when they leave us, many of the male birds have not attained their full plumage. Those who frequent the salt water are more backward in this respect than such as feed in the fresh waters; nor are the former ever in such good condition, or so well flavoured, as the latter.

There are very large flocks of the oyster-catcher, the curlew, and the knot, on the sand-banks, etc. Whenever these birds want to alight on any spot, if the wind is at all high they invariably pitch with their heads straight to windward; if they come down the wind to their resting-place, they first fly past it, and then turning back against the wind, alight with their heads in that direction.

At this season salmon and trout frequent those 
parts of the river where the stream is the slowest, or lie in dead water, apparently not having the strength, which, in the warm weather, enables them to lie perfectly at their ease in the strongest rapid.

Amongst the curious instincts which birds display in providing themselves with food, one most resembling reason is that which teaches the commoncrow, on finding on the shore a shell containing fish, to fly with it to a height in the air, and then to let it drop in order to break the shell sufficiently to get at the fish enclosed in it. When the shell does not break the first time that the crow drops it, she darts down, picks it up, and ascends still higher, till she perceives that the height is sufficient for her purpose. Sometimes another crow darts in to carry off the booty, upon which a battle ensues in the air. Cunning as the crow is, she seldom finds any prize without letting all the neighbourhood know of it by her cries and gestures. With perfect truth the ancient poet said-

"Tacitus pasci, si posset corvus, haberet Plus dapis, et rixæ multo minus invidiæque."

The crows collect great numbers of sea-shells on particular favourite hillocks, which are often at some distance from the sea. I have frequently observed in this country great collections of this kind, and from the state of the shells it would 
appear that they bring them to the same place for many successive years.

In some of the woods the thrushes and blackbirds carry the land-shells to certain fixed stones, against which they break them, in order to get at the snails. In a wood of "Brodie" where the round yellow and black-striped shell (Helix nemoralis) is abundant, owing I conclude to the rocks under the surface being limestone, I watched two thrushes bring several of these shells in a very short space of time; they knocked them against the stone, and if that did not do, they struck the shell in a crevice and hammered away at it until they extracted the snail, with which they then flew away, probably to feed their young. Whenever I passed through the wood I always visited the thrushes' stone, and found an increasing heap of broken shells. Most birds, if carefully watched, would be found to have recourse to various most surprising expedients in order to obtain food for themselves and their young.

In this country April is the best month for the Bean-geese, yet many weary and often fruitless miles I have walked in pursuit of them. There is something in the wildness and wariness of this fine bird that makes it a peculiarly attractive object of pursuit; but wild-goose shooting is

" Omnium rerum incertissima."

VOL. I. 
When I have concealed myself in one of my hiding-places in a newly-sown field of oats or peas, the geese, after keeping me perhaps a long time waiting, may arrive at last; and alighting on the field, may commence feeding without any suspicion of danger till they come nearly within shot. But although concealed from the geese, I may be visible in a different direction, when a couple of villainous large black-backed gulls - as happened to-daycame by, and seeing me lying in wait in a suspicious manner, immediately commenced screaming and wheeling over my head. The geese, who are all dispersed in the field, no sooner hear the gulls than they run rapidly together away from me, for they know by the direction in which the gulls are looking where the danger is; they then rise and betake themselves straight to the sea, leaving me without the chance of a shot, after all the trouble I have had in preparing an ambuscade.

One day this month, too, after endeavouring for some time to approach unseen some white-fronted geese, one of which I was very anxious to procure for a friend, I saw the birds go to a pool where I knew I could get within shot of them without the least trouble. So making a considerable circuit, I arrived at a part of the ground from which my approaching the geese was perfectly easy. But just 
then some peewits saw me as I was advancing in a crouching attitude up to the birds. Had I been walking upright, these peewits would not have taken any notice of me; but the moment that they saw me stooping to conceal myself, they attacked me with screams and cries of alarm sufficient to warn all the country. The geese of course took wing, and left me to return as I came.

To stalk a flock of wild-geese when feeding is as difficult, if not more so, as to stalk a stag. From the nature of the ground which they feed on, and their unwearied vigilance, unless you have concealed yourself beforehand within reach of their feeding-place, it is nearly impossible to approach them. Even if some half-dry ditch or drain passes through the field, and is of sufficient depth to hide the sportsman, supposing he has strength enough of back and of resolution to walk in a stooping position up to his knees in cold water for some hundreds of yards, still the birds are most unwilling to approach any such line of ditch, or indeed any other place which can possibly conceal an enemy.

One of my boys, however, succeeded in getting at this same flock of white-fronted geese in a place where a man could never have done so. He was out for a walk with a gentleman who was staying with me, to whom he was acting as cicerone or 
guide to the lochs, as I was unable for some reason to go out with him myself. The little boy took the telescope, which their attendant carried, and having looked along the shores of the lakes and through all the likely parts of the ground, which he knew as well as I did, from having frequently ridden that way to join me, he shut up the glass with the exclamation characteristic of a deer-stalker- " There they are!" My friend's question of course was"Who are there?" And on being told it was a flock of geese, he at once understood why he had been led on from point to point under different excuses; for he had good-naturedly followed passively wherever he was told to go. Having been shown the geese, he sat down with the glass and allowed the child to attempt the task of stalking them, but without having the slightest expectation of his success.

Having watched him for some time till he became invisible, having apparently sunk into the ground amongst the rushes and long grass, his attention was next attracted by seeing the geese suddenly rise, and almost immediately perceiving that one fell to the ground. The next instant he heard the double report of the boy's gun. Another goose left the flock and fell at some distance, but it was unnoticed by him and the servant, as their 
attention was taken up by the young sportsman, who went dashing through water and swamp to seize the first bird that fell: it was nearly as big as himself, and he brought it up to them in triumph, a successful right and left at wild-geese being rather an era in the sporting adventures of a boy ten years old. The well-earned game was then slung across his pony in company with sundry rabbits, etc., and was brought home with no small exultation.

The Shetland pony, than which I never saw a more perfect one, is of great use in many ways. After the hours devoted to Latin, etc., are over, one of the boys, when the weather is tolerable, generally rides out to meet me, if $\mathrm{I}$ am in ground which I cannot drive to; and having anchored his pony to a weight sufficient to keep him from wandering far, but not too heavy to prevent his feeding about the rough grass, furze, etc., he joins me, and the pony has all the hares and rabbits slung across his back to save the shoulders of the old keeper. Standing fire perfectly, the little Shetlander seems rather to enjoy the shooting, and to take an interest in what we kill. With proper treatment and due care these Shetland ponies become the most docile and fine-tempered animals in the world; but if once they are badly used they soon become as 
full of tricks and as vicious as a monkey. The only bad habit of which I could never break ours was opening every gate which hindered his getting out. There was scarcely any common fastening which he would not undo with his teeth, and if he found a weak place in railings he would push against it till he broke it, and then gallop away for an hour or two where he chose. He also had a peculiar knack of finding out and opening the oat-chest in any stable. When out on a marauding excursion of this kind he knew perfectly that he was doing wrong, and would not allow me to catch him, although at home he would follow me anywhere, putting his nose into my hand to ask for apples or bread. At all times, however, he allowed any one of the children, particularly my little girl, to catch him, and when caught always came back as quietly as possible. There was a great deal of fun and conscious roguery in the little fellow's style of mischief which one could never help laughing at. When idle in his field nothing seemed to please him so much as a game of romps with any dog who would play with him.

When I lived close to Nairn, as soon as ever he heard the horn of the mail-coach, which was blown on its arrival at the inn, he invariably ran to an elevated part of the field, from which he could see 
over the wall, and waited there for the mail to pass. As soon as it came opposite his station off he set, galloping round and round the field with his heels generally higher than his head, and his long mane and tail streaming out, evidently showing himself off to obtain the applanse of the passengers, to whom he seemed to afford daily amusement, as every head was turned back to see him as long as they possibly conld.

Riding by the heronry on the Findhorn I saw the keeper at Altyre searching in all the jackdaws'nests that he could reach for the remains of the herons' eggs. These active little marauders live in great numbers in the rocks immediately opposite the herons, and keep up a constant warfare with them during the breeding season, stealing an immense number of their eggs, which they carry over to the holes and crevices of the opposite rocks and eat them, out of reach of the herons. The keeper took handfuls of the shells of the herons' eggs out of some of the jackdaws' holes: the injury to the heronry from this cause must be very great, as the plundering seems to be incessantly going on.

I see that the peregrine falcon still breeds near the heronry: a pair only remain in the rock, as every season they drive away their young ones to find a resting-place elsewhere. The barn owl also 
breeds in the rocks of the Findhorn : not having towers or ruins to breed in, they adapt themselves to their situation and take to the rocks.

The male of all hawks, I believe, feeds his mate while she is sitting on her eggs. Whilst I was fishing in the Findhorn, at a place where a great many kestrels breed, one of these birds came flying up the course of the river with a small bird in his claws. When he came opposite the rock where the nest was, he rose in the air and began to call loudly and shrilly for his mate, who soon came out from the rocks, and taking the bird in her talons flew back with it; the male bird, after uttering a few cries expressive of pleasure, flew off to renew his hunting.

The time at which roe lose the velvet from their horns seems to depend on the lateness or earliness of the season. This year (1848) is backward, and as late as the 15 th of this month $I$ see that the horns of the bucks are still covered with the velvet. In early seasons their horns are quite clean by the 4 th or 5 th of the month. When the larch and other trees become green, the roe wander very much, taking to the smaller woods and grassy plantations in search of some favourite foliage or herbage. A fine buck came to an untimely end at Darnaway. Mr. Stuart on his way to fish, was going along a 
narrow footpath on the top of the rocks which overhang the river, when his dogs, rumning into the cover, started a buck, who, taking a sudden spring into the footpath, found himself unexpectedly within a few inches of Mr. Stuart, in fact almost touching him. Without pausing for an instant the frightened animal with another spring went right over the high rocks into the deep black pools of the river below. Mr. Stuart got down to the water and managed to pull the roebuck out, but the poor animal was quite dead, killed by the shock of jumping from so great a height, although his fall must have been much broken by the water.

When a crow leaves her nest on being disturbed, her quiet, sneaking manner of threading her way through the trees tells that she has young or eggs in the thicket as plainly as if she uttered cries of alarm. These birds are early breeders: I found a hooded crow's nest with eggs nearly hatched on the 16th April.

The common wild-duck often builds her nest in a situation from which one would suppose it would be very difficult for the young, when first hatched, to make their way to the water. My retriever put up a wild-duck on the 16 th in some very high and close heather at some distance from any water. I found that she had her nest in the very centre of 
the heather and in the densest part of it. The nest was very beautifully formed; it was perfectly round, and looked like a mass of the finest down, with just sufficient coating of small sticks, etc., outside to keep the down together. There were thirteen eggs in it, which we took home and put under a bantam hen : they were hatched in a few days, and I allowed them to go at liberty with their foster mother in the kitchen garden, where they soon became perfectly tame. When the gardener digs any part of the ground the little fellows immediately flock about his spade, so that it is difficult for him to avoid hurting them, as they tumble about on the newly-turned up earth, darting at the worms which come into view; whenever they see him take his spade they run after him as if they thought that his only object in digging up the ground was to find them food. One tiny fellow, who is weaker than the rest, and who consequently gets pushed out of the way by his stronger brethren, waits quietly to be lifted up on the flat of the spade, where the gardener allows him to stop out of the reach of the others, while the little glutton swallows a worm nearly as big as himself. The moment the spade is laid flat on the ground he knows that his turn has come, and running on it looks out for the expected worm, and is quite 
APRIL. BRENT GOOSE-POCHARD-RIVER-TROUT. 219

fearless although raised on the spade several feet from the ground.

There are few wild-birds or other animals which could not be tamed and made useful to us if, instead of constantly persecuting them, we treated them with hospitality and allowed them to live in peace and plenty. All wild-fowl are susceptible of domestication, and there are very few kinds which would not breed in a tame state.

Most wild-fowl require very little extent of water as long as they have grass-fields to walk about and to feed in. No more water is necessary than is sufficient for them to wash and take an occasional swim in.

Our brent goose seems to eat scarcely anything but grass, and any snails and worms it may find in the field. He is a far more graceful bird on land than the pochard, for quick and active as the latter is in the water, his great flat feet, placed far behind, are of little service to him in walking.

The eye of the pochard is of a most wonderfully clear bright red colour, something between crimson and scarlet, and is quite unlike that of any other water-fowl that I am acquainted with.

April, if the weather is fine and genial enough to bring out many flies, is about the best month for trout-fishing on the Findhorn. Large river-trout, 
which are seldom seen at any other time of the year, make their appearance in this month and rise freely; the sea-trout fishing, lower down near the sea, is equally good, the fish being numerous and eager to take the fly.
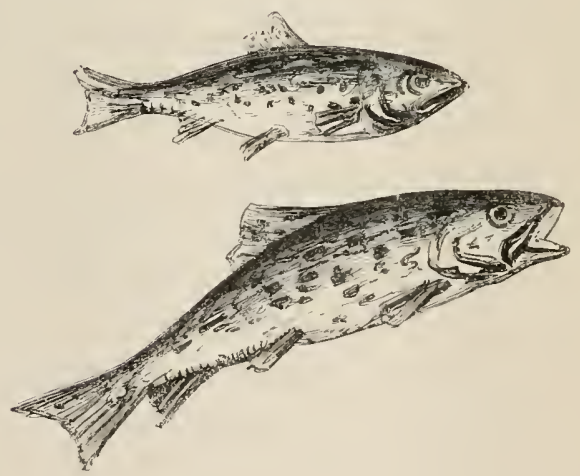


\section{CHAPTER XVI.}

MAY.

Nests of Birds - Cross-bills, etc. - Lateness of Season-BeanGeese-Partridge's Nest-Northern Diver-Coot's NestTeal and her Young-Wren's Nest-Badgers ; cunning of ; anecdote of-Aurora Borealis; sound made by.

IN this region May is invariably ushered in by the croak of the landrail. Generally this bird is heard on the 1st. If, however, the grass and wheat fields are backward, it is not heard till the $2 \mathrm{~d}$ or $3 \mathrm{~d}$, but never later than the $3 \mathrm{~d}$.

On the 1st of May we found in an old crows' nest, placed in a tall Scotch fir-tree, the nest of a horned owl, with one young bird, laalf-grown, and a rotten egg. The owls hoot now very much, and though none breed very near the house, I hear them every night in the ash-trees.

The young thrushes, blackbirds, robins, and hedge-sparrows will soon be hatched; but the greenfinches, chaffinches, etc., although their nests are nearly completed, have not yet laid any eggs; the insectivorous birds being the first to build.

Swallows, martins, swifts, and wheatears become 
numerous about the first week in May, and the landrail's call is heard from every patch of clover. The movements of the landrail are very peculiar and amusing: at one moment threading the clover with its head bent to the ground, and looking more like a weasel than a bird; the next, standing perfectly erect, and uttering its hoarse cry with a voice of brass. I saw one to-day standing upright between the legs of a cow, and crying boldly, as if perfectly aware that the cow was not an enemy.

Whilst fishing in the upper part of the river I saw numbers of crossbills and siskins in the beautiful woods of Dulsie. The nests of these two birds are scarcely ever found, although they certainly breed plentifully in this country. The siskin conceals its small nest with great care at some distance from the ground, generally near the summit of a spruce fir; while the crossbill places its nest, which it assimilates as much as possible to the colour and texture of the moss, on some good-sized horizontal branch of a fir-tree, so that it is nearly invisible from below.

When the season is late the fish are also late in taking the fly. The natural fly does not come to maturity this year as early as usual, in consequence of the herbage not having come up; and the want of flies on the water keeps the fish from coming 
out to the streams and pools of the river, where the angler expects them.

There is much snow on the Monaghleahd mountains this year (1847); and in consequence of this melting gradually from the heat of the noonday sun, the water rises at a certain hour daily; here, at Dulsie, the rise takes place about three or four in the morning. Having risen for an hour or two, it again falls to its usual level.

May 6.-The salmon-fry begin to appear.

May 7.-I observe a flock of bean-geese in the bay, probably the last I shall see this year, as it is time for them to be nesting in the far north. On this day, also, the spotted fly-catcher appeared in the garden, where it builds every year in one of the apricot trees.

During this month the oyster-catchers remain in larger flocks than at any other time of the year, although many are breeding far inland on the stony banks of the Findhorn, Spey, and other rivers.

The partridge covers its nest and eggs with perhaps greater cunning than any other bird, entirely concealing not only the nest itself, but so disposing the surrounding grass that no vestiges of its track to and fro can be seen: they commence laying here about the 10th of May. The landrails are about a week later. 
I have often observed that the black-headed gull eats a great deal of corn in the newly sown fields; and I now find that the lesser black-backed gull does the same, as I shot one which had a handful of corn (oats and barley) in its crop, mixed up with worms, grubs, etc.

The fishermen at Nairn found, on the 26th of this month, a very fine northern diver, drowned in the stake-nets set for salmon. They tell me that it is not a solitary instance, as every year they get one or two at this season. This is another proof that this bird must breed somewhere on the Scotch coast, although I never heard of its eggs being found.

The coots and dabchicks have already commenced making their large platform of a nest. I found one on the loch which the bird had fastened on a floating tree that had grounded in a shallow; but which, having again got adrift, owing to a rise in the loch, had been driven by the wind until it stuck fast close to the shore, where the old bird was still at work. One bird seems to remain in the nest while its mate brings it rushes, which the stationary bird disposes of by adding them to the already large structure, till it seems sufficiently high above the water and solid enough to resist wind and weather. The whole nest is firm enough to bear a much greater weight than is ever imposed on it. 
Everywhere on the lakes are broods of young wild-ducks, either swimming in close order behind their mothers, or all huddled together in a heap on some little island or projecting point of land.

As we were out driving the other day, a teal came fluttering ont of the dry ditch by the roadside, and for above a hundred yards continued flying and running almost under the horse's feet. I found that she had a number of young ones unable to get over the wall, so we helped them into the adjoining wood. They were a long distance from the water, and had very rough ground to pass over to reach it. I remember exactly a similar circumstance happening to me in Ross-shire, when I also saved the lives of a young brood of teal by lending them a helping hand. These instances prove that, notwithstanding the instinct of birds, which generally enables then tokeep their young out of harm's way, they occasionally get them into a situation not only of difficulty, but where any dog or mischievous boy coming along might destroy the whole brood. At every ebb tide now, the terns fish with great perseverance for the sand-eels, on which they almost entirely feed.

The month of May this year appears to have quite changed its character; instead of being warm and genial, we have nothing but cold and cutting east winds; and the mountains have lost but very VOL. I. 
little of their winter covering of snow ; indeed, on the higher inland mountains their white dresses extend down very nearly as low as in the winter. But notwithstanding the bad weather there is mucls to amuse and interest one in the sheltered parts of the low country. Every plant and flower is bursting into beauty, in spite of the cold blasts; and the small birds are in full activity and seem at the height of their happiness. It is also a constant source of amusement to us to watch the various ways of building and the different nests of the small birds. Eachnest has its own character, and each bird its own place of concealment. The little willow wren forms one of the most interesting nests, which it places either under a bush in the flower-garden, or in a rough grass-field, where it forms a kind of dome-shaped nest, made to assimilate completely with the surface of the surrounding ground.

The common wren, too, is very choice and careful in the structure of her nest, and sometimes builds in the most singular situations. I saw one this year which was built in a cactus that hung from the roof of a greenhouse. Every time the little bird wished to add a leaf, or a piece of moss, she had to squeeze and twist herself in through a small hole left for the entrance of a vine stem. Her perseverance and determination were extraordinary; for in spite of all 
difficulties she managed to form an immense nest in this singularly chosen and picturesque abode. It is difficult to imagine what could have put it into her head to come into the greenhouse at all,and through so awkward an entrance, surrounded, too, as she was by places far more suitable and easy of access.

The badgers live a life of great activity now. In this country they are seldom destroyed : at least, there is one large tract of very wild country, the soil of which is sandy and suitable for their digging propensities, where also they are not often trapped. The badger, when once he has been frightened by, or has escaped from a trap, is not easily caught again ; but displays a cumning and perseverance in eluding all attempts at his capture which he is not generally supposed to possess.

I seldom declare war against these animals, not considering them very mischievous; but some time ago, wanting one for a friend, I set a strong trap with bait near one of their holes. A large badger got in, but managed to escape before I came to the trap. I set it again; and the next morning, on going to it, I saw from a distance a number of hooded crows, perched in a tree near the place, in a state of great excitement. On coming up, however, instead of the badger I found an immense gray cat, closely resembling a wild-cat, both in colour 
and ferocity, and who flew straight at me on my approaching her. Having killed her, I left her near the place, covered over with sand; the badgers came and scratched her up, and nearly devoured her by the next morning; so I put traps about the remains of her body; but they managed to spring every trap without being caught, and for several days they escaped in the same way. The traps were always sprung; the badgers' tracks were all round them, and the baits invariably taken away. At last, determined not to be beat, I baited my trap with an apple, as something new and unexpected to them, and immediately caught what I wanted, a fine old badger.

My old keeper was sitting on a hillock about three o'clock one morning in the beginning of May, watching quietly a few wild-geese which he had discovered feeding in a field not very far off, but out of shot. In this hillock was a badger's hole. Presently he heard a grunt behind him, which he took for a pig; and looking round he saw, standing in a clover field close to him, an immensely large badger, whose object seemed to be to get into a hole on the hillock, to reach which he had no alternative but to pass within a yard of the man's legs. After they had looked at each other for some time in this way, the 
badger at last uttering a most ill-natured kind of grunt, suddenly put his nose to the ground, and passing close to the keeper made a rush to the hole, with all his hair standing straight on end, and showing his teeth in so determined a manner as completely to take away all presence of mind from the old fellow; so much so, indeed, that he neither shot at him nor obstructed his free entrance to the hole in any way. He tells me that when he has been sitting quietly watching for geese, otters, etc., he has not infrequently seen the badgers going about together in companies of three or four.

There was a heary gale of wind at the beginning of this month. I was out late with the keeper, and just before it commenced we saw a very brilliant aurora borealis; or, as they term it here, "The Merry Dancers." He told me that when the aurora was very bright, and the flashes rapidly waving through the sky, he had frequently thought that he heard the merry dancers emit a faint rustling noise, like the "moving of dead leaves," but this was only when the night was quite calm, and there was no sound to disturb the perfect stillness. The idea came from him quite uncalled for by any remark of mine, and was entirely the result of his own actual observation. I was pleased to hear him say this, as I had more than once imagined 
that the aurora, when peculiarly bright and rapid in its movements, DID actually make exactly the sound that he described; but never having heard it asserted by any one else, I had always been rather shy of advancing such a theory.

The aurora is seldom seen, or at least seldom attentively watched in this country, in situations where there is not some sound or other, such as voices, running water, or the rustling and moaning of trees, to break the perfect silence; but it has occasionally happened to me to be gazing at this beautiful illumination in places where no other sound could be heard, and then, and then only, have I fancied that the brightest flashes were accompanied by a light crackling or rustling noise, or, as my keeper expressed it very correctly, "the moving of dead leaves." Whether this is so or not I leave to others, more learned in the phenomena of the heavens, to decide, and only mention the circumstance as the passing remark of an unscientific observer.

In the northern mountains of Sutherland, where the aurora is frequently very bright and beautiful, there is a fascinating, nay, an awful attraction in the sight, which has kept me for hours from my bed, watching the waving and ever changing flashes lancing to and fro. I have watched this strange 
sight where the dead silence of the mountains was only broken by the fancied rustling of the "dresses" of the "merry dancers," or by the sudden scream or howl of some wild inhabitant of the rocks; and I have done so until an undefinable feeling of superstitious awe has crept over my mind, which was not without difficulty shaken off.

The aurora, bright as it sometimes is in this country, must be far more wildly and vividly splendid in the more northern and Polar regions. Here it is almost invariably the forerunner of change of weather, or of rough winds and storm.

One night this spring the appearance of the aurora was very peculiar. All the flashes seemed to dart from a common bright centre in the heavens: this continued for some time, until, at length assuming its usual form, it remained comparatively stationary above the north-eastern horizon, and from that quarter there came the next day a severe storm of sleet and wind. 


\section{CHAPTER XVII.}

\section{JUNE.}

Trout-fishing-Sea-trout in the Findhorn-Breeding-place of Black-headed Gulls-Salmon-fishing-Gray CrowsHair Worms-Fishing-Cromarty-Goats-The Peregrine Falcon.

In June the trout begin to feed more freely, and from most Highland streams the sportsman may reckon on a good basketful if the day is tolerable. There is a kind of trout in the Findhorn which frequent only the lower pools near the sea; higher up I never saw them; the fishermen call them "brown lugs." In appearance they are between a sea and a river trout: they seldom exceed a pound and a half in weight.

One day, about the 1st of June, when fishing in a clear pool near the mouth of the river, a large trout came out from under the bank, and darted over my fly without taking it. I changed the fly, and he did the same thing. I tried him with a dozen different sorts, and he invariably played the same trick, coming out from under the bank, dashing at the fly, then turning short round or rolling over it. At last a miniature black midge in my 
book caught my eye, and I put it on: the moment I cast this fly over the trout he came straight at it in quite a different manner, taking it well into his wide mouth as if at last in earnest. He was well hooked, and then came the tug of war and the trial of patience. The fly was literally speaking a midge, made more as an experiment in fly-making than for any expected use, and it was tied on the finest gut. The trout, on finding that instead of catching a fly he was caught himself, immediately began to try every device that a trout ever imagined to get rid of his tiny enemy. Now he was down at the bottom rubbing his nose on the gravel: the next moment flying straight up into the air with the agility of a harlequin; sometimes with forty yards of line out, and sometimes right under iny feet; then away he went as if about to run over the shallow at the end of the pool on his way to the sea, but changing his mind, darted like an arrow up to the deepest part of the pool, and there he lay like a stone at the bottom. After a little waiting I pelted him out of that mood, and beginning myself to grow eager and desperate (moreover having now more confidence in my midge, which had already passed through a trial which a larger hook might not have stood equally well), I turned his head down the stream, and began to take the game 
into my own hands a little more-in fact to be the active instead of the passive agent. The trout, too, began to feel weary of the contest, and to allow himself to be led about: at last I brought him to the edge, but just as the landing-net was being delicately slipped under him, away he went again, and ran the line round a broken piece of bank on the opposite side. ' I am afraid something very like an imprecation escaped me; and if it did, I am confident that Job himself could not blame me. Just as I had quite given all up, the trout most carefully and good-naturedly turned back the way he went, undoing the line again as neatly as possible. After a little more running to and fro he fairly gave in, and this time we got him safely into the landing-net, when I found that he was one of the aforesaid "brown lugs," weighing nearly 5 lbs.- - the largest trout that I ever killed on the Findhorn, and mastered too with a fly only fit for parr of the smallest size.

I have frequently found that when a large trout runs in that undecided manner at my fly, he will go in right earnest at a much smaller one. Salmon are more uncertain: it has lappened to me that, even in clear water, a salmon has leaped over or refused a small salmon-fly, but has taken greedily a very large-sized one. But this is an exception; and my experience would lead me, as a general 
rule, always to offer a fish a smaller fly than the one he rises shily at; and I believe that I should be borne out in this opinion by more experienced anglers than myself.

I never saw so many black-headed gulls collected together as on the Loch of Belivat, on the property of Lethen : at one end of the loch there are a great many rushes and water-plants; these are, literally speaking, FULL of nests, formed of interwoven rushes, weeds, etc.; and on the islands in the lake you can scarcely land without putting your foot on eggs, which are very slightly protected by anything in the shape of a nest. On this island are a few stunted and bent willows; every branch and every fork of a branch where a nest can possibly be placed is occupied: this is the only instance I ever met with of gulls building on bushes. The stench on the island is almost insupportable; indeed it was so strong that I hurried off again as quickly as possible: the day was hot, and it actually seemed pestilential. The old birds looked like a shower of drifting snow over our heads, and were as noisy as a dozen village schools broken loose. This was on the $2 d$ of June, and there were numbers of young gulls recently hatched-curiously marked little tortoiseshell-coloured things who tottered about the rushes, etc., without the least fear of us. 
All other birds seemed to be kept away from the lake by the gulls, excepting a few mallards, who were swimming about in a state of bachelorhood, their wives and families being probably in some more quiet and solitary pool in the neighbouring peat-mosses. When the mallards rose they were so completely puzzled and "bebothered" by the thousands of gulls who were darting and screaming about them, that they gave up attempting to fly away, and came plump down again into the water.

Although the gulls may know each its own nest, it is difficult to understand how they can recognise their young ones amongst the thousands of little downy things which, towards the end of the hatching season, are floating about upon the water. There is another nesting-place of the black-headed gulls in the forest of Darnaway, where they have taken possession of a small loch surrounded by trees. They usually, however, like all other water-fowl, prefer establishing their breeding-place on a loch situated in the open country, where they can have a good view all around so as to descry the approach of any enemy; but undisturbed possession and quiet have induced them to remain on the Darnaway loch, although it is shut in by trees.

June is generally the best month of the year for angling in Scotland: the loch trout are by this time 
in good condition, and rise freely at the fly. The grilse also are now in most of the rivers, and afford better angling than any other fish, rising well, and being strong and active when hooked. There appears of late years to be a great diminishing in the number of salmon in all the Scotch rivers: the fish are more protected from the angler, but are caught and destroyed in so many other ways - by constant netting in the streams, by innumerable stake-nets, hag-nets, etc., all along the coasts - that they have but little chance of keeping up their numbers. From one end of Scotland to the other along the whole extent of the coast, these destructive nets are fixed at every convenient place. Near the mouth of every stream, large or small, they are to be seen, and immense must be the number of fish taken to repay the expense of keeping them up, and renewing the stakes, netting, etc., every spring, and frequently also after severe storms. Near the little stream of Nairn there are no less than three of these nets, and as many more between that point and the Findhorn, all of which are exposed to a heavy sea, which must make the expense of keeping them in repair very great.

On the bar, which is a kind of island, there is a solitary hut, where two or three fishermen pass the spring and summer. In the latter end of winter. 
when I have been wild-fow] shooting in that direction, I have often gone in to screen myself from the cold. During the absence of the fishermen the hut is tenanted by rabbits, who make themselves quite at home, digging holes in the turf walls, etc. The life of the fishermen in this place must be like that of a lighthouse-keeper. During high tides they are quite cut off from the mainland, and although at low water their place of abode is no longer an island, yet that part of the shore opposite the bar is a kind of wilderness little frequented by any one, being at a long distance from any road or path, with an extensive tract of rough and all but impassable country extending in every direction. It is, however, a favourite resort of mine, being the undisturbed abode of many wild animals. The roebuck and blackcock live in tolerable security there, and would increase to a very great extent were their young ones not killed by foxes and other vermin, who prowl about without danger of trap or poison.

I had heard that the lochs here called Loch Lee had no fish in them of any kind; but seeing the numerous tracks of otters, and also the cormorants frequently fishing in them, I determined to ascertain what these animals came for; being pretty sure that some kind of fish must be the attraction. Accordingly, having made up a long "set line," i.e. 
some two hundred yards of line with strong hooks at intervals of four or five yards, I set it, as far as it would reach, across one part of the largest lake, baiting the hooks with small trout and worms. The next morning on examining the line I found a great number of large eels on the hooks, several of them weighing above four pounds each. Although I frequently afterwards put in the line, I never caught any fish excepting eels, but of these a vast number. This proves how favourite a food of the otter eels must be, as these animals appear to live constantly at the loch, where they could have found nothing else to prey upon. A highland loch without trout is, however, a rare thing, as they are almost invariably well stocked with them.

There are one or two grassy hillocks near these lakes to which those mischievous robbers, the hooded crows, bring the eggs which they have pilfered in order to eat them at their leisure; and until I administered a dose of strychmia, I never passed these places without finding the fresh remains of eggs : partridges, plovers, snipes, redshanks, woodpigeon, ducks, and teal, all seemed to have contriliuted to support these ravenous birds. There was a nest of a teal with eight eggs in a small thicket of heather, in a situation apparently secure from all risk of being discovered. I only knew of it in con- 
sequence of my retriever having put up the old bird. Frequently, afterwards, I saw her on her downy nest, but one day both teal and eggs were gone; and when I went to the grassy hillock which the crows used for a dining-table, there were the remains of all the eight eggs.

Poisoning with strychnia is by far the most effectual way of destroying crows. If you put a piece of carrion in a tree well seasoned with this powerful drug, the ground below it will soon be strewed with the bodies of most of the crows in the neighbourhood, so instantaneous is their death on swallowing any of it. It seems almost immediately to paralyze them, and they fall down on the spot. In the stagnant pools near the river Nairn there are great numbers of that singular worm called by the country people the hair-worm, from its exact resemblance to a horsehair. In these pools there are thousands of them twisting and turning about like living hairs. The most singular thing regarding them is, that if they are put for weeks in a drawer or elsewhere, till they become as dry and brittle as it is possible for anything to be, and to all appearance perfectly dead and shrivelled up, yet on being put into water they gradually come to life again, and are as pliable and active as ever. The country people are firmly of opinion that they are 
nothing but actual horsehair turned into liviug things by being inmersed for a long time in water of a certain quality. All water does not produce them alike. To the naked eye both extremities are quite the same in appearance.

While fishing in the river one day at the beginning of June, my attention was attracted by a terrier I had with me, who was busily employed in turning up the stones near the water's edge, evidently in search of some sort of food. On examining into his proceedings I found that under most of the stoules were a number of very small eels: where the ground was quite dry the little fish were dead, and these the dog ate; where there was still any moisture left under the stone they were alive, and wriggled away rapidly towards the stream, seeming to know instinctively which way to go for safety. Trout have undoubtedly the same instinct; and when they drop off the hook by chance, they always wriggle towards the water, and never away from it. I saw a trout one day who had been left by the receding of the river in a shallow pool. When the water in his narrow place of refuge had got so low as scarcely to cover him he worked his way out of it, and I saw him go over the still wet stones straight to the river, which was about a yard from the pool. It is difficult, indeed almost impossible, to become VOL. I. 
much acquainted with the habits of fish; but could we pry into their domestic circles, I have no doubt that we should find them possessed of a far higher degree of instinct and much greater cleverness in providing for their food and safety than we give them credit for. The instinct of fish in foretelling, or rather in foreknowing, the changes of weather is very remarkable; and the observant angler may almost prophesy to a certainty with regard to the approach of rain or storms by seeing in what mood for rising at his flies the trout may be. In certain states of the weather the angler may put away his tackle without trying to take a single trout; but this can only be learned by experience and close observation.

Sometimes, on a fine June evening, the sea-fish, such as gurnets and coal-fish, take a large white fly readily enouglı, and fight most powerfully when of any size.

I took a boat one day to cross over to the rocks of Cromarty, in order to shoot some rock-pigeons. The breeze was gentle, but sufficient to take us merrily over; and putting out a couple of lines with large white flies, we caught plenty of gurnet, etc. The fish darted suddenly and with true aim at the flies when close to the boat as readily as when at some distance. After coasting along the 
rocks for some time, and shooting a few pigeons, at the risk occasionally of having the bottom of our boat stove in by the hidden rocks round which the large tangle floated gracefully in the passing waves, treacherously concealing the rocks from which they grew, we turned our boat's head homewards. By this time the wind had dropped entirely, and the tide running strong against us, we had to row for four hours in a heavy haddock boat to reach our destination. I had only one man and a boy with me, the latter of no use; so I took an oar myself and pulled steadily on, stopping only occasionally to haul in a gurnet or other fish.

Both goats and sheep were feeding about the rocks, and even the latter seemed to get easily to places which appeared to be reachable only by means of wings. The small patches of bright velvety-looking grass, which grew here and there on corners of ground formed by the débris of the cliffs, however difficult of access, were all tenanted by them.

On one bit of emerald-coloured grass, not larger than a good-sized tablecloth, a sheep and her young lamb were feeding at their ease. Although I stopped the boat and examined the place carefully, no way of access to this little bit of tableland could we discover. The well-contented 
animals seemed shut out by perpendicular precipices from all the rest of the world.

As for the goats, no ledge or projection of the rocks near which grew any tempting bit of herbage seemed too small or too difficult of approach.

About three weeks ago our tame pochard had been carried away in a hurricane of wind. To my surprise, one day this month I saw this same pochard swimming about the loch alone, and apparently very tame. One of the children who was with me, and whose own especial property the bird had been, whistled to it in the same way in which he had been accustomed to call it, upon which, to his unbounded joy, it immediately came towards us, and for some time continued swimming within a few yards of where we stood, evidently recognising us, and seeming glad to see us again.

A few days afterwards we again saw him; but he was now accompanied by a flock of fourteen or fifteen others. This was remarkable, both on account of the time of year, and because this kind of duck is very rare in this region, and has never been known to breed in the neighbourhood; but all birds seem to have some means of calling and attracting those of the same species, in a way that we cannot understand.

My peregrine falcon, who still lives in the 
garden, now utters a call which is different from her usual shrill complaining cry, and which occa. sionally attracts down to her some wandering hawk of her own kind. The peregrine falcon is well named, for it is found in all countries.

Our bird from good food, and having always had the run of a large garden, instead of being confined in a room or cage, has grown to a great size, and is in peculiarly fine plumage; with the dark slate colour of her upper feathers forming a beautiful contrast to the rich cream-coloured shade of her neck and breast.

There is scarcely any common animal too large for her to attack when she is hungry. She will fly at $\operatorname{dog}$ or cat as readily as at a rabbit or a rat. The latter animal she kills with great dexterity and quickness; and I have also found the remains of half-grown rabbits who, having feloniously made their way into the garden, have fallen a prey to her powerful talons.

On changing my residence some weeks ago I gave a tame peregrine falcon I then had to a friend in the neighbourhood, who keeps her in a walled garden, where she soon became quite at home, and learnt to know her new master as well as she had known me. She almost startled me one day as I was walking in his garden with a bunch of dark- 
coloured grapes in my hand. The falcon, as I passed by her, mistaking the grapes for a bird or some other prey, made a sudden dash at them, and with such violence as in an instant to disperse the whole bunch on the ground, where she hopped about, examining grape after grape, and at last having found out her error, she left them in disgust.

It must be a strong bird that can withstand the rapid powerful swoop and fierce blow of a peregrine. I have seen one strike the head off a grouse or pigeon with one blow, which divided the neck as completely as if it had been cut off with a sharp knife.

Few birds of the same kind vary so much ir size as peregrine falcons. Some killed in a wild state are almost as large as the noble ger falcon. Altogether the peregrine is the finest of our British falcons both in size, courage, and beauty. It possesses, too, the free courage and confidence which facilitate so greatly the process of training it to assist us in our field sports. 


\section{CHAPTER XVIII.}

\section{JULY.}

Shore Birds; arrival of-Foxes-Herring, and Herring-fishing ; Birds, etc., feeding on them-Herring-fishing in Sutherland-A Sharper-Numbers of Flounders - Young Wildfowl-Roe; habits of - Midges-Angling-Floods in the Findhorn-Prophecy of a Woman-Escape of a Shepherd.

About the second week of July the shore and sands are enlivened by vast flocks, or rather clouds, of dunlins, ring-dottrels, and other birds of the same kind, who now, coming down from their scattered breeding-places, collect in immense companies. When the tide ebbs, all these birds are employed in searching for the minute shell-fish and animalcula on which they feed; and vast indeed must be the supply required. About the lochs and swamps the young snipes and redshanks begin to fly, and with the wild-ducks afford plenty of shooting.

The young sea-gulls, too, are numerous about the bar and sandbanks, and are easily distinguished from the old ones by their fine mottled brown plumage.

Great numbers of all these birds must be killed by foxes, etc.; for every day I observe their fresh 
tracks along the shore and round the lochs. Near a fox's hole in one of the woods I saw an almost incredible collection of remains and disjecta membra of ducks, turkeys, fowls, game of every kind, and even of roe: apparently a litter of young foxes had been brought up in it.

On the 12 th of July the Nairn herring-boats are all launched to reap their uncertain harvest of herrings. Of late years the supply does not seem to be nearly so regular or so much to be depended on as formerly; and frequently the men are but badly repaid for all their expense and risk. The cost of a herring-boat here, complete, with its rigging, nets, etc., is not much less than ninety pounds; and the wear and tear of the nets is very great, owing to bad weather and other causes: the hull alone of the boat costs about twenty-seven pounds. There are five men in each boat; and Nairn alone sends out about sixty boats, so that from that small place not less than three hundred able-bodied men are for six or seven weeks employed in the pursuit of this small but valuable fish. The herrings are generally bought up beforehand by the fish-curers at Helmsdale, on the Sutherland coast, and at other parts, who contract to take the whole proceeds of the season's fishing at a fixed price; so that, notwithstanding the immense number caught, the supply of 
fresh herrings through the country is but scanty. The fish are, with as little delay as possible, packed in casks with brine, and in this state are exported to all parts of the kingdom. The barrels are made principally of birch. Fir will not answer the purpose, as it gives a taste of turpentine to the whole contents of the barrel. I have been out in a herring-boat during the fishing; and a very beautiful sight it is to see the nets hauled in with thousands of herrings, looking in the moonlight like so many pieces of the brightest silver flashing in the calm water. When not employed with the nets, the men generally fish with hooks for cod, halibut, etc.; all fish caught in this manner being the perquisite of the man who catches them; and frequently they make a good profit by this, as the cod collect in vast numbers about the herring fishing-grounds, and are caught as quickly as the hooks can be dropped into the water. Sometimes the cod, their great indistinctly-seen forms looking like the pale ghosts of fish, come close to the surface round the boats, and seize the bait as soon as it touches the water. Hauling these heavy gentry up from the depth of several fathoms is very severe work for the hands.

The herrings seem the most persecuted of all the races of living creatures. From the moment when the great shoals of them appear in the north and 
north-west, they are pursued by thousands and tens of thousands of birds and countless numbers of fishes; and wherever the herring shoals are, there are these devourers. From the aristocratic salmon to the ignoble and ferocious dog-fish, all follow up and prey upon the shoals; whilst their feathered foes mark out their track by the constant screaming and plunging into the water which they keep up during their pursuit. The Solan geese from midair dash with unerring aim on the bright and silvery fish; whilst the cormorants and other diving seafowl pursue the dense crowd with indefatigable eagerness. In addition to all this, sea-gulls of every kind, like the skirmishers of an army, keep up a constant pursuit of all stragglers or wounded fish which come near enough to the surface to be caught by these birds, who have neither the power of the Solan goose, to pounce hawk-like on their prey (even when at some depth from the surface), nor the diving power of the cormorant or guillemot, who can pursue them deep down into the water. Altogether, a shoal of herring, with its numerous accompaniments, is a most amusing and interesting sight, independent of the consideration of the great importance of this fish to mankind, the number of people to whom it serves as food, and the number who are employed in its pursuit. 
Besides the natives of the fishing villages, a considerable number of Highlanders from the western part of the country come down to earn a few pounds during the herring season; it is almost the only cash these poor fellows get hold of in the course of the year. Most of the boats belong to two or three proprietors each, who having in the course of many years laid by a few pounds, expend them in the purchase of a herring-boat. These men hire the services of four or five hands for the season, the duration of which is about six weeks, and give them a certain sum, according to agreement, generally about four to six pounds per man. Unluckily, many of the families of the herring-fishers derive but little benefit from the wages earned, as too frequently the men spend all the money, or nearly all, in drinking and rioting as soon as the fishing is over, and, instead of providing for their wives and children, are too apt to lounge about the whiskyshops as long as a farthing remains, never attending to the haddock or other fishing till driven again to exertion by sheer necessity. This, however, does not apply to the whole race of herring-fishers. Those men who come to the fishing on the east coasts from the Highlands generally take their money carefully home, depending on it for buying clothes, paying rent, procuring seed-potatoes, 
and for any purpose where ready money is required.

To the spectator the pursuit of herrings in the magnificent sea-lochs of Sutherland is attended with much that is interesting and beautiful. When the fleet of boats makes its way up a creek running far into the land, and overhung by wild rocky precipices, which protect the boats from every breath of wind, keeping the sea as smooth as glass, and echoing and re-echoing every merry shout and call uttered by the fishermen during their pursuit, no description can give an adequate idea of the romantic beauty of such a scene with all its accompaniments. This, however, is the bright side of the picture, for many a dangerous gale and many a peril have the poor fellows to encounter who shoot their herring-nets off the bleak eastern coasts of the country, where they are exposed to the sudden gales and rolling seas of the Northern and German Oceans. Frequently, to save their lives, they are compelled to abandon their nets, fish, and all. Sometimes boats with their crews go forth to return no more, nor even to be again heard of in this world; and at other times they are driven to distant ports for safety, losing their tackle and time, and having to make their way back with scanty supply of provision to the port from which 
they sailed, and probably losing their chance of fishing for the whole season.

Would it be believed that the herring-fisher, humble as his situation in life appears, is occasionally the object of a regular and systematic plan of swindling? A few years ago, a fellow made it his occupation and business to waylay these poor men as they returned home from the fishing-stations with their hardly-earned money in their pockets. His plan was to get into conversation with them, and after walking a mile or two along the road with them, to take generally one, but sometimes two, into a whisky-shop, of which there are plenty on every Highland road, under the pretence of treating them to a dram. Then, as opportunity offered, he produced a small flask from his pocket, which he said contained a sample of some rare whisky (having previously represented himself as a spiritmerchant travelling for orders), and as a special favour gave the fisherman a glass of its contents. It was no sooner swallowed, however, than the man became powerless and almost insensible; upon which the fellow quietly emptied the pockets of his victim and walked off, leaving him to recover as he could: which event in most instances did not take place for some hours afterwards. If, in going out, he met with the keeper of the whisky-shop, he told 
him that the man was asleep from fatigue, or made some such excuse to escape suspicion. In this manner the fellow robbed above twenty fishermen of the whole proceeds of their fishing before the country got too hot for him; when he went off by the coach and was no more heard of. The whole proceeding was described to me by one of his victims (at present in my service) who was robbed of about five pounds; and, notwithstanding the cruelty of the case, I could not help being amused at the coolness with which the swindler appears to have turned the poor fellow's pockets inside out, the man all the while being quite conscious of what was going on, though utterly unable to move or speak. To add insult to injury too, on going out the swindler told the landlady that he was sorry to say the fisherman had got quite drunk, notwithstanding all the efforts he had made to prevent it and all the good advice he had given him. When at length the poor fellow recovered his senses and power of speech, he found it quite impossible to persuade his wife and friends that he had not wilfully and advisedly got drunk and squandered his money. However, at last the fair one was pacified, though not much comforted; her husband's innocence being proved by the testimony of others who had been robbed in a similar manner, and by the 
verdict of the doctor, who at once saw that some strong narcotic had been given to the man.

Among the available products of the sandy creeks and bays on this coast are immense quantities of excellent flounders. These fish come in with every tide, and though the great bulk of them return to the deep water, vast numbers remain in the pools which are formed at low water upon the sands. We occasionally drag some of these pools with a small trout-net, and are sure to catch a large quantity of these fish in one or two hauls. The flounders are of two kinds, the gray-backed flounder and a larger sort which has red spots. The latter, however, is a far inferior fish, the flesh being soft and flabby. Notwithstanding the abundance and excellence of the flounders, left, as it were, for any person to pick up, with scarcely any exertion, the country people very seldom take the trouble to catch them, excepting now and then by the line, in a lazy, inefficient way.

July, although not a month during which the sportsman finds much employment for his gun, is still to me a most interesting season. Every day that I walk by the lochs and swamps I see fresh arrivals in the shape of broods and flocks of young teal and wild-ducks, and this year there are numbers of pochards swimming about in compact companies. 
Occasionally, too, when walking near the covers, an old roe, accompanied by her two large-eyed fawns, bounds out of some clump of juniper or brambles; and after standing for a short time to take a good look at me, springs into the wood and is soon lost to view; or an old solitary buck, driven by the midges from the damp shades of the woods, startles me by his sudden appearance near the loch side, springing over the furze and broom, on his way back to the more extensive covers.

The roe have a singular habit of chasing each other in regular circles round particular trees in the woods, cutting a deep circular path in the ground. I never could make out the object of this manœuvre, but the state of the ground proves that the animals must have run round and round the tree for hours together.

Tormented by midges and ticks, the bucks often wander restlessly through the woods at this season, uttering their bark-like cry; so like indeed is this sound to the bark of a dog, that it often deceives an unaccustomed ear. Of all torments produced by insects I can conceive nothing much worse than the attack carried on by the myriads of midges which swarm towards evening in the woods, particularly where the soil is at all damp. For a certain time the smoke of a cigar or pipe protects 
one; but no human skin can endure for any length of time the inexpressible irritation produced by these insects.

This month is not, generally speaking, favourable to the anglel. Salmon seem in most rivers to have given up moving, and the trout follow their example. Indeed the rivers are at this period very subject to great changes, being one day bright, clear, and very low; and perhaps the next flooded over bank and brae by some sudden and tremendous thunder-storm in the higher grounds, which renders the water thick and turbid. The Findhorn is peculiarly subject to these rapid changes, flowing as it does for a great part of its course through a mountainous, undrained, and uncultivated country, surrounded by lofty and rugged heights, from the clefts of which innumerable streams descend into the valley of the Findhorn. 'This river', on any sudden and violent storm of rain (fed as it is by so many burns), rises sometimes almost instantaneously; and what a few minutes before was a bright clear stream, fordable at all the shallower places, suddenly becomes a turbid swollen torrent, which neither man nor horse can cross. In those parts of the river where the channel is narrow and confined between steep and overhanging rocks these sudden risings take place more rapidly than in the lower VOL. I. 
parts near the sea, where the river has room to spread itself out.

One day towards the end of the month I went with my two boys and a servant to shoot rabbits on the island formed by the junction of the Findhorn and another stream near the sea. The river was so low, in consequence of long-continued dry weather, that we crossed it on foot at a shallow where the water did not reach to our knees. The day was hot and the air heavy and oppressive; and although we had not had a drop of rain, we heard loud thunder during the whole morning, and saw heavy black clouds hanging in the west over the mountains through which the river runs. After idling about some time and shooting a few rabbits, etc., we went towards a small cottage built on the highest part of the island, in order to speak to the people who inhabited it. Whilst standing close to the door we heard a sudden scream from a woman at work in the little plot of garden, and looking round we at once saw the cause. The river, as the woman emphatically expressed it, was "coming down." Over a wide space of sand and shingle, interspersed with patches of broom and furze, where a few moments before we had been hunting rabbits, there now came rushing down a wall of muddy water, carrying with it turf, stones, and 
trees, rolling over and over, and uprooting every bnsh which opposed it. Several of the trees must have come some miles down the river, being large Scotch firs, with their branches, stem, and roots, the latter frequently still carrying in their twisted fibres great masses of the rocks on which they had grown. The water was coming down like a wall of several feet high, sweeping everything before it; and in far less time than I have taken to describe it, we were smrrounded on all sides with its muddy torrent. Independently of the risk of being crushed to death by the floating and rolling trees, its rapidity was so great that the strongest swimmer could not have crossed it.

On came the flood, narrowing our little island every instant, by undermining and washing away the bank on which the cottage stood. Nevertheless I anticipated no more inconvenience than perhaps having to pass the night where we were: for the building had stood all the torrents of the Findhorn since the great flood of 1829 , although its inlabitants had more than once been eut off from any communication with the mainland for several days together. But the water was already higher than it had ever been since that flood, and the women of the house were weeping in despair, their terrors being angmented by a prophecy which had lately 
been uttered by an old hag in the neighbourhood, to the effect that all the country within six miles of the coast should be swallowed up by floods during the last week of this very July. So strong an effect had this prediction on the minds of the lower orders, that almost all the Highlanders who had come down to the coast, according to their custom, for the herring-fishing, had returned homewards without putting their foot in a boat, to the great loss and inconvenience of the owners of the boats and nets, who had reckoned on the usual assistance of these men. It is singular that floods of a most mischievous and unusual extent should actually have taken place at the very time this woman had foretold.

For my own part, I felt chiefly annoyed at the alarm our absence would occasion at home, as it was already evening, and we had no means of making signals or of sending word where we were, it being quite impossible to cross the river at any point.

The water still rose, and continued to do so for half an hour longer, washing away our standingplace slowly but constantly. On looking round I could not but feel most grateful at our not having been overtaken by it before we reached this part of the island. Had we been in many of the places over which we had so lately passed, we must have 
been swept away at the first rise of the river, or, at best, have had to wade and scramble, at the risk of our lives, to some elevated point of land.

While standing near the house we saw two or three boats belonging to the ferryman and the salmon-fishers whirl past us. The flood having come on without the least warning, their owners had had no time to secure them. The rise, as I have said, continued for about half an hour, then suddenly it stopped, and in a few minutes the water began visibly to fall. Before long it fell more. quickly, but still in no proportion to the rapidity with which it had risen. After it had been sinking somewhat above an hour, the tops of furze bushes began to appear above the water, and soon afterwards we saw a boat belonging to the salmon-fishers, well mamned, and assisted by a rope held on the shore, coming down to a cottage a quarter of a mile above us. The main stream of the river was still quite impracticable; but this boat was coming down an old channel which was generally dry. By firing off my gun several times I caught the attention of the crew; and I was quite certain that they would know who it was that wanted help, and would come to us if possible. When the torrent had become somewhat less violent they came down, whirling through the flood to where we were. They 
took us on board, and by dint of skilful and strong rowing, and help from the rope held by those on shore, we were at length landed in a field, not across the real channel of the river, but across the flooded land on the other side of us, where the force of the water was less violent. Although I have been in a good many situations of danger by water, I never felt so helpless as whilst we were dashing about at the mercy of the torrents, over bushes, banks, and stranded trees; had we come in contact with any one of which our small boat must have been upset, and then all chance of escape would have been out of the question. However, we landed safely, and although we were not above a quarter of a mile from my house, we had to walk round by the chain bridge, a distance of five miles. We got home soon after dark, and before our absence had caused any alarm. With us the rain did not begin till the evening, but we afterwards heard that, farther to the west, it had rained in torrents for many hours during the morning, accompanied by a most terrific thunderstorm, and that a great deal of damage had been done by the overflowing of different streams, which had broken up several bridges, and injured a great extent of land. A poor woman who happened to be wading the river a mile above us, at a place where it is divided into several streams, 
was caught in one of them, and although she managed to get upon a high bank, the flood soon reached her, and she was kept a prisoner, standing in the water, which at one time reached to her middle, till the fishermen heard her cries, and succeeded in rescuing her. Had we been in many spots where we fished almost every day nothing could have saved our lives.

A singular instance of preservation from a similar danger happened during this same flood, but on a different river. On perceiving that the water was rising, a young man hurried across a shallow part to an island, on which were a few sheep grazing, intending to recross with them to the mainland before the flood had attained any serious height. He was, however, out in his reckoning; for he had scarcely set foot on the island when the river became so swollen that it was quite impossible for him to return. The flood soon covered the island, and the man had great difficulty to keep his footing, being up to his waist in water. To add to his danger, great pieces of timber and floating trees came sweeping past, any one of which, had it struck him, would have at once dashed him off the island. Several people who were on the shore, although so rear, could do nothing to assist him. Presently the flood brought down, right upon the island, a 
gigantic tree, with all its roots and branches, and it seemed certain that he must be swept away at once. He was given up by all the spectators, and they turned away their eyes, not daring to look at this last act of the scene. However, the very moment when the danger seemed the greatest was that of his deliverance; for the tree, in consequence of its great size and weight, grounded when within a yard of the man. He managed to scramble on to its branches, and to maintain his position until the waters subsided.

What becomes of the trout during these sudden floods it is not easy to say, unless, warned by instinct of the approaching danger, they retire to the deep holes and recesses under the banks, where the force of the water canuot reach them. It is very seldom that, on the receding of a flood, fish are found on the land, though certainly it occasionally happens that they are bewildered, and are either left high and dry or in the small pools at the sides of the river. When, also, the same cause that has made the stream overflow has filled the water with clay and dirt, the trout become sick and weak, and are unable to contend with a force of current which they could easily have withstood in clear water.

As the flood decreases both trout and eels take 
to all the eddies and corners to feed on the numerous worms and grubs which are washed off the banks and fields into the water.

Very few birds, or, comparatively speaking, even land animals, fall victims to floods. The rabbits manage to climb up into the highest furze bushes, or even into the branches of trees, and it is very seldom that any birds make their nests within reach of this danger. In the same manner that terus and other birds who lay their eggs on the sea-shore seem to have an instinct which teaches them the exact line to which the highest springtides ever reach, so do the land birds avoid building their nests in places to which the land floods ever ascend.

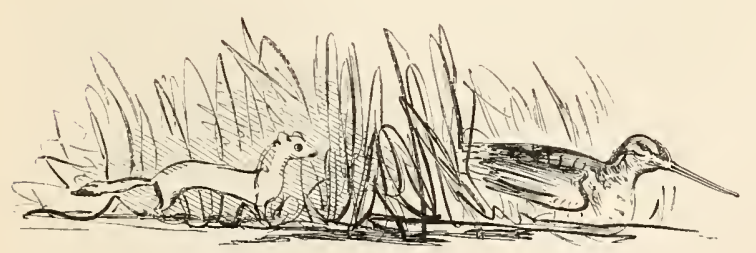




\section{CHAP'TER XIX.}

\section{AUGUST.}

Golden Plover-Ring - dottrel-Migratory Birds-ButterfliesCrabs; their manner of casting their shells-The Sea Angler - The Deal Fish - Habits of Woodcocks - A pet RoeGrouse-shootings and Grouse-Wild-fowl.

DuRivg the first part of this month the mountainbred birds, such as golden plover, dottrel, curlew, etc., are daily seen to collect more and more in flocks on the sea-shore or other places which suit their habits. In the lower parts of the country the dottrel is now a very rare bird, and it is seldom that many of them are killed, although they are so tame and easy of approach as to have obtained for themselves the local name of the "foolish dottrel." It is one of the peculiarities of this bird that one pair only breeds on the same hill or mountain. Whilst you may see thousands of golden plovers on a hillside during the breeding season, you will never find above one pair of dottrel on each ridge. The ringdottrel and other shore birds become at this season more numerous day by day. Many insectivorous birds, also, such as the whitethroat, redstart, etc., seem to draw gradually towards the eastern coasts 
of the kingdom, as if in readiness to depart. The wheatears almost entirely leave the wild rocky mountains of the North, where they breed, and are during this month caught in great numbers on the south downs of Sussex.

The regularity of the appearance and disappearance of birds in different districts is one of the most striking and interesting parts of their history, and is a subject worthy of more attention than it has hitherto received. It is well known to many sportsmen that woodcocks appear in certain woods, and even under certain holly bushes, or other favourite spots, on the same day of the same month, year after year ; and in like manner and with equal punctuality do numberless smaller birds, of less notoriety and of less consequence to the sportsman, make their annual flittings northwards or southwards. On referring to notes which I have made during several years, I find that I have seen many migratory birds for the first time in each year, on either the very same day of the month or within one day of it.

Even in the insect world the same punctuality in their change of abode is kept up, and an observant "out-of-door" entomologist will tell almost to a day when any particular moth or butterfly will first appear. The exclusiveness of some butterflies as 
to their locality is a very striking peculiarity of this insect. You may, year after year, find a certain kind in great numbers within a space of a hundred yards, but you may search in vain for a single specimen over the whole surrounding country; although both as to plants and soil it may seem as favourable for their production as the spot to which they confine themselves. I was told by a clever entomologist that I should find any number of specimens of a particular butterfly, which I wanted to procure, in a certain stone quarry, or rather where a quarry had once been, during the first and second week in August, but at no other time and in no other situation. My friend was perfectly right. Then and there, and then and there only, could I find this particular butterfly. There are few districts of the kingdom where a man of leisure would not find plenty to interest and amuse him were he to direct his attention to the peculiar habits and instincts of living animals from the highest to the lowest, from the eagle to the insect which he treads unconsciously under his feet every step he takes. People little know by how many natural objects of beauty and interest they are everywhere surrounded. How true is a French saying that "L'oisiveté est la mère de toutes les vices ;" and how many cares and troubles would thousands 
avoid did they employ their leisure hours in such pursuits instead of letting idleness lead them into numberless evil habits! It is for this reason that I always like to see the study of natural history encouraged in children.

At the beginning of August I frequently find the crabs (which frequent the rocks left exposed at low water) either just about to change their shell, or just after having changed it. Nothing can be more curious than the manner in which they contrive to draw their legs and claws out of their last year's covering, casting their entire shell perfectly whole and unbroken. A tough skin seems to form over the flesh, under the shell, and of the same colour, which apparently hardens rapidly by exposure (when it is uncovered), and this skin forms the new shell.

The poor animals are quite helpless till this hardens, and are at the mercy of their numerous enemies. The fishermen say that whilst the female crab is in this weak state the male constantly attends on and protects her. I have myself often seen a crab in her still unhardened shell, closely accompanied by a larger crab, whose shell was perfectly hard, and who offered battle most valiantly when he and his spouse wcre approached.

During the herring-fishing it frequently happens that some strange and rarely seen monster of the 
sea gets either entangled in the nets or is cast upon the shore during his pursuit of the shoals of smaller fish. Among others I have more than once seen a most hideous large-headed brute of a fish, whom the country people call sometimes "the sea-devil," sometimes "the sea-angel," but whose more regular cognomen is, I believe, "the sea-angler." The first name he owes to his excessive and wickedlooking ugliness; the second must have been given him ironically; whilst the third is derived from his reputed habit of attracting fish to their destruction by a very wily ruse. He buries himself, it is said, in the sands by scraping a hole with his two most unseemly and deformed-looking "hands," which are placed below what may be called his chin. Being in this way quite concealed, he allows some long, worm-like appendages, which grow from the top of his head, to wave and float above the surface of the sand: fish taking these for some kind of food are attracted to the spot, when the concealed monster by a sudden spring manages to ingulf his victims in the fearfully-wide cavity of his mouth, which is armed with hundreds of teeth sloping inwards, and as hard and sharp as needles, so that nothing which has once entered it can escape. So runs the tale, the exact truth of which I am not prepared to vouch for. 
A rare and singularly formed fish was once brought to me during the month of August by the fishermen. It is called the "Deal-fish," or, locally, the "Saw-fish." The latter name is very expressive of its shape and proportions, the fish being flat vertically instead of, like a sole or flounder, horizontally. The following is the description of the fish which I set down at the time:

Length, 3 feet 6 inches.

Depth, 7 inches.

Greatest thickness, between half and three quarters of an inch. Colour, bright silver, with one very thin crimson fin rumning the whole length of its back.

The tail very transparent, fan-shaped, and of a bright crimson.

A large flat eye ;

And a small mouth, which the fish had a peculiar power of elongating to a cousiderable extent.

It had managed to get hooked through the back by a common haddock-hook. I wished to have preserved the skin, as I believe that there are not above one or two perfect specimens extant; but, unluckily, through a mistake the fish was destroyed.

August 4th.-We caught a young woodcock full grown in one of the woods near here. A dog disturbed it in the cover; and it flew fluttering into the road, where it allowed itself to be caught by the hand, although it was quite as large as an old bird, and its wings apparently fully feathered. 
The woodcock breeds every season in the north of Scotland, not only in the large fir plantations, but also in the smaller patches of birch, etc., which fringe the shores of many of the most northern lakes. That those bred in the country migrate I have no doubt, as they all invariably disappear for two or three months between summer and the first frosts of winter. As I have seen their nests at all times from March to August, it is natural to suppose that the woodcock breeds more than once in the season.

I have again, this year, seen the old woodcocks carrying their young down to the soft marshy places to feed. Unfitted as their feet appear to be for grasping anything, the old birds must have no slight labour in carrying their whole family (generally consisting of four) every evening to the marshes, and back again in the morning. They always return before sunrise.

Occasionally I have come upon a brood of young woodcocks in a dark, quiet, swampy part of the woods, near which they had probably been bred. In a case of this lind we may suppose that the old birds are saved the trouble of conveying their young to a distant feeding-place; but as the young birds are frequently hatched in long heather, in dry situations, and far from any marshes, they would in- 
evitably perish in the nest were they not daily carried backwards and forwards by their parents. The quantity of worms required to sustain one of these birds would astonish those town-bred naturalists who gravely assert that the woodcock "lives on suction."

Whilst walking in a wood I was surprised at seeing a roe standing within a little distance of me, with a silver bell hung round its neck. Having taken a good look at me, the beautiful little animal bounded off into the recesses of the wood, ringing its bell, to the astonishment of the rabbits who were feeding about the openings of the cover. This roe belonged to the ladies at Darnaway; and, with the usual wilfulness of such pets, had wandered away from its proper home, where it lived in security and plenty, petted by all, and had taken up its abode in the wood, which was several miles from Darnaway, and where it ran the risk of being worried by colley dogs or shot while feeding in the neighbouring corn-fields. Once or twice afterwards, when I was shooting in this wood, the beagles started and ran the roe some distance before I could stop them. As long as he continued ringing his bell through this cover I seldom saw any other roe in it, although at other times it was a favourite resort of these beautiful creatures. Once it followed, for some VOL. I. 
distance towards Darnaway, a servant who had been accustomed to feed and pet it, but taking alarm at some people at work in a field it turned back again. I do not know what was the end of the pretty animal, but towards the winter it disappeared, and I fear it was shot by some poaching fellow whilst feeding in the fields where it was often seen. Its silver bell made it both an easier and a more valuable victim.

August 12th.-On this (to so many people) dies memorabilis, whilst shooting with a friend in Inverness-shire, I found a few old grouse lying dead, killed by the prevailing disease, which of late years has committed such havoc amongst these birds in certain districts; some which we killed were already attacked by it. Whenever this was the case we invariably observed that the plumage of the bird was much altered, having a rusty red appearance instead of the fine rich colour characteristic of the grouse. The feathers, too, had an unnatural kind of dryness about them, which gave the bird a bleached, unhealthy, look. In those grouse which I opened myself the presence of the disease was indicated by the liver being apparently rotten.

Whatever is the cause of this mortality, it is a matter of some consequence to the proprietors of those districts where the grouse-shootings let for as 
high or a higher rent than the sheep pasturage; for it can scarcely be expected that Englishmen will continue paying at the rate they do for the right of shooting over tracts of ground where the grouse are becoming alnost extinct, as is the case in several places. Instead of sparing the birds where they are attacked by this epidemic, I should be much more inclined to shoot down every grouse in the infected part of the hills; and I would continue to do this as long as any appearance of the disease remained. I would then give them a year or two of rest, according to the numbers and appearance of the birds. This seems to me the most likely way to check the destruction caused by what the keepers call the "grouse disease." In some parts of the Highlands there were scarcely any young birds seen in August, and the old grouse were picked up in dozens, dead on the heather.

I observed one peculiarity in the habits of the grouse in 1847 , which was new to me. They were collected in large flocks on the 12th of August in the fields of oats in the elevated districts, which were at that time perfectly unripe and green. In every field near the moors there were large flocks of the old birds busy in the midst of the corn; but they always took the precaution to leave some sentries outside, who, perched on a piece of rock or an 
old wall, stood with their necks stretched to their utmost height, on the look-out for any approaching enemy. When the corn is ripe, and especially after it is cut and in sheaves on the fields, the grouse are very fond of it, and fill their crops daily with oats, like so many chickens, but before this season I never saw them attack the green and empty oats. There was at this time a very unusual deficiency in the growth and bloom of the heather, causing a great scarcity of the tender shoots which form the principal food of grouse; and this may have driven them to the new kind of food, to which they appeared to take very kindly.

It is in the oat-fields belonging to the small farmers and others living near the grouse hills where the greatest havoc is committed amongst grouse by the poachers, for there they can be caught with the greatest facility, in any number that may be required for the market; and it is more difficult for keepers to prevent this kind of poaching than any other, as it may be carried on by girls or children late in the evening and early in the moruing, the snares being removed during the daytime, or on the appearance of a keeper, whose approach in this kind of open country may be perceived from a sufficient distance to enable the poacher to remove all traces of his proceedings. 
Thousands of grouse are killed in this manner for the London and other markets.

This year, 1848 , on the very first day of the shooting, I happened to be in a poulterer's shop in a large town in Northumberland, when a servant came in to buy a brace or two of "well-kiept grouse, fit for immediate use," for his master: and a brace was instantly handed to him from amongst a great number, which looked as if they liad been killed a week or ten days; at any rate they were nearly putrid, and according to my taste fit only to be flung away. If this system commences so long before the birds are legally saleable, we may easily imagine what an immense number of grouse are illegally destroyed during the whole season, in spite of all the expenses incurred to preserve them.

In my opinion this wholesale system of poaching might easily be put a stop to by the proprietors of the land, who, by stringent agreements with their sheep-tenants and cotters, might prevent all trespassing on the hills, much more easily than the tenants of shootings can do; and, really, considering the great profit in many ways that this bird is to the Highland landowners, it seems both their interest and duty to protect and assist sportsmen in every possible manner in preserving the game: 
whereas, let the matter be glossed over as it may, every lessee of grouse-shootings knows how very little assistance and encouragement he receives from nine proprietors out of ten, notwithstanding the liberal and sometimes exorbitant rents which are paid. There are, however, many exceptious to this state of things; and landlords are yet to be found who identify the interest of their tenant with their own.

The rage for grouse-shooting, at present so great, is not likely to change, like many other fashions. The fine air, the freedom, the scenery, and all the other agremens accompanying this amusement, must always make it the most fascinating kind of sport in the way of shooting which the British isles or indeed almost any country can afford. The bird, too, in beauty and game-like appearance, is not to be equalled. In fact, as long as grouse and heather exist, and the nature of man is imbued with the same love for sport and manly exercise as it now is, grouse-shooting will be one of our favourite relaxations from the graver cares of life.

Although, like others, I am excessively fond of this sport, yet I care little for numbers of slain; and when following it, independently and alone, am not occupied solely by the anxiety of bagging so many brace. My usual plan when I set out is to 
fix on some burn, some cool and grassy spring, or some hill summit which commands a fine view, as the extremity of my day's excursion. To this point then I walk, killing what birds come in my way, and after resting myself and dogs, I return by some other route. Undoubtedly the way to kill the greatest number of grouse is to hunt one certain tract of ground closely and determinedly; searching every spot as if you were looking for a lost needle, and not leaving a yard of heather untried. This is the most killing system, as every practised grouseshooter knows; but to me it is far less attractive than a good stretch across a range of valley and mountain, though attended with fewer shots. I am also far more pleased by seeing a brace of good dogs do their work well, and exhibiting all their fine instinct and skill, than in toiling after twice the number when hunted by a keeper, whose only plan of breaking the poor animals in is to thrash them until they are actually afraid to use half the wonderful intellect which nature has given them.

Although the 20th of August is the day appointed for legal execution of the blackcock, yet in most seasons the 1st of September would be quite soon enough for the shooting to begin, as until the commencement of September the young birds have seldom acquired their strength or plumage, and can 
be knocked down before the pointer's nose with a stick almost as easily as shot; indeed I have frequently seen them caught in the hand. When in full vigour and plumage there is no handsomer bird than an old blackcock, and although his size makes him an easy mark, lis cunning and strength are pretty good securities for his not falling too readily to the sportsman's gun. But in August even the old birds are not fit to shoot, being neither in perfect condition nor in full plumage. The blackcock is much more addicted to feeding in the corn-fields than the grouse is, and takes long flights for the purpose of reaching some favourite stubble-field.

Few stags have got the velvet off their horns during August, except in favoured situations, where good feeding in the spring and winter has enabled them to keep up their condition and the strength which is required for the production and growth of their weighty antlers.

I find that towards the end of August, when the hill lakes and swamps are much disturbed by grouse-shooters, the wild-ducks bring down their young broods in great uumbers, both to the bay and to the lochs. Every evening I can make sure of killing a brace or two as they fly to the corn-fields regularly when the sun sets; indeed they sometimes do considerable damage by trampling down 
and eating the corn before it is cut. But some of the wild-ducks which are killed in the bogs and swamps have their crops full of the seeds of a coarse grass which grows in these places, and also of some of the wild-fruits, such as blackberries, etc. Indeed I fancy that a wild-duck is about as omnivorous a creature as can be found, almost as much so as the man who eats him: nothing which he can swallow comes amiss to him, whether fish, flesh, or grain. The teal, on the contrary, appears to be almost wholly insectivorous: at least these birds feed only in the swamps and shallow pools, never taking to the fields for grain or seeds, but living entirely on aquatic insects and some few small plants.

Although the widgeon breed in Sutherlandshire, and perhaps in other parts of Scotland, I never saw one in this part of the country during July or August. I believe that this bird feeds neither on grain nor insects, but on aquatic grasses; and when these are not to be had, he grazes readily on the grass-fields and banks near the sea.

The great art in getting at most wild-fowl is to discover their feeding-places; for to these they always resort at certain times either of the day or of the tide, some kinds being more dependent than others on the ebb and flow of the sea; whilst the 
common mallard is almost wholly nocturnal in his feeding, and does not regulate his movements by the state of the tide.

The sheldrakes, who were so numerous a few weeks ago about the sandbanks and bar, have now nearly all disappeared, and their places are supplied by innumerable curlews and other waders, all of whom appear to find their food in the moist sands left by the ebb-tide, which in this country contain an endless supply of shellfish of different kinds, from the minutest species, fit only to feed the dunlin and sandpiper, to those which serve for food to the oyster-catcher, whose powerful bill is well adapted to breaking up the strongest cockles and mussels which are found in this district.

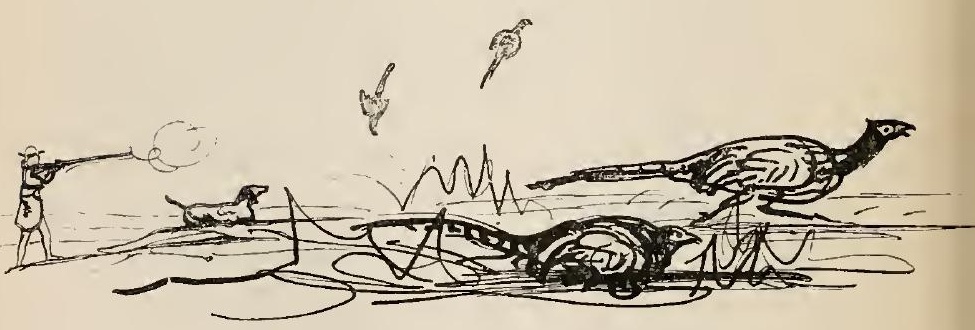




\section{CHAPTER XX.}

SEPTEMBER.

The 1st of September-Partridge-shooting-Migratory Birds-

Grouse-shooting in September - Widgeon - Jack-snipes ;

Breeding places of -Landrail-White variety of the EagleSea - trout fisher-Stag's horns-Deer-stalking-Cunning of Deer-Disappointed in getting a Shot.

THe 1st of September is by no means so marked a day with sportsmen in the north as it is with those in the southern parts of the kingdom. I well remember the eager haste with which, when a boy, I used to sally forth at the earliest dawn to wage war on the partridges. The birds, however, at that hour, are restless and on the alert, the gromnd is wet, and the sport unsatisfactory; and in fact no one, I believe, who can number more than sixteen summers ever got up at three o'clock to shoot partridges without repenting his undne activity before mid-day.

In this country very little of the corn is cut at the commencement of September, and I never attempt to shoot more partridges than I may happen to want for the larder. As long as the fields are covered with standing corn the only way is to liunt 
quietly round the hedgerows, and banks exposed to the sun, or in dry soiled turnip-fields, during the middle of the day, when the birds come to bask and scratch. Both partridges and hares stick close to standing corn as long as an acre of it remains.

In this country, however, the wild-fowl and other birds which frequent the shores and rocks always afford me as amusing sport as the best partridgeshooting; and at this season there is always a constant and endless variety of migratory birds collecting previous to their departure.

There is one very numerous class of birds, the sandpipers and others of the same kind, which are very little known. Even the best and most quoted authors of works on natural history are constantly in error with regard to the names and classification of these birds, and although I do not pretend to be acquainted with all, or nearly all, the varieties, I know enough of them to perceive that the numerous changes of plumage which each species goes through, according to their age, sex, and the season of the year, have completely misled most naturalists. Indeed to know these birds perfectly requires much greater attention and more minute examination than has yet been expended upon them. Such also is the case as regards sea-gulls, and some kinds of hawks, though with these the difficulty is not so great. 
I always find that the grouse are wilder in September than in any other month. They are well scared and driven about by the August shooting, and are not yet tamed down by the autumnal frosts and cold.

In this part of Scotland we have much wild and stormy weather in September; and many an English sportsman towards the end of the month, when located in some small shooting-lodge, in the wild and distant glens of the inland mountains, begins to think of turming his way southwards. The incessant rain, driving pitilessly down the glen where his confined and badly-built cottage is placed, rivers turned into torrents, burns changed into rivers, and the grouse unapproachably wild-all combine to drive away many a southem sportsman before the end of this month; and yet October and November often are better months for grouseshooting than the latter part of September.

Here, in Morayshire, we have a more favourable climate, and it is very rarely that there is any long continuance of bad weather in the lower parts of the county. Many a storm passes harmlessly over our heads, to fall on the high grounds a few miles from the coast. These storms of rain or snow, although they pass over us, have always the effect of lowering the quicksilver in the weather-glass, as 
certainly as if they fell here, instead of only threatening to do so.

The earliest day on which I ever killed or saw widgeon in Morayshire was on the 8th of September, on which day I shot a brace, late in the evening, as they flew over my head on their way from the bay to some inland lake. They were both young birds. The flock altogether consisted of eight or nine. In the same year I killed a jacksnipe on the 16 th, which is far earlier than these birds are usually seen (I have never yet ascertained that they breed in Britain), and during the next ten days I killed four others in nearly the same place, some of which were undoubtedly young birds. It may, therefore, be supposed that a chance pair may occasionally breed in the North, as it does not seem likely that those which I killed had been bred out of the kingdom. In no other year have I ever seen a jack-snipe before the 8th of October; even that is very early. I have made much inquiry on this subject in Sutherlandshire and in other likely localities; but have invariably found that where the jack-snipe has been supposed to have been seen during the breeding-season it has turned out to be the dunlin, or the common snipe. Neither their eggs nor young have ever been found, nor has the old bird been seen, for a certainty, in Britain 
during the summer season, excepting in the case of a single disabled bird.

The landrail is seldom seen here after the corn is cut, notwithstanding the great numbers which breed in the neighbourhood. It is peculiarly a summer bird; and although its cry is hoarse and inharmonious, I never hear it without pleasure, associated as it has become in my mind with the fine light nights of June and May. A fearless little bird it is, too, when caught uninjured. I have seen it immediately after being made a prisoner, and while held in the hand, peck at and catch with wonderful rapidity and precision any flies that might pitch within its reach. Its manner of departure from this country would appear to be still unexplained, as it is never seen en route either by landsmen or sailors. When this and other insectivorous birds leave us, winter visitors arrive. The turnstone, a bird that breeds in Norway, arrives in this country at the first commencement of the month, but appears only to make it a temporary resting-place on its way to the south.

Like many other birds, the eagle sometimes exhibits great changes in the colour of his plumage. This year during the month of September I saw a freshly killed sea-eagle, whose colour was a fine silvery white, without the shightest mixture of 
brown. The bird was killed in Sutherlandshire; and I was informed that another eagle had been seen in its company with the same unusual plumage. The bird had quite arrived at maturity, but did not appear to be a very old one. Partridges, pheasants, grouse, and many small birds occasionally appear in a snow-white dress; but the birds of prey seldom change their colour. A black swan we read of as an example of a "rara avis ;" what must then a white crow have been thought of by the augurs and omen-seekers among the ancients? Yet rooks and jackdaws, both parti-coloured and white, are by no means so uncommon with us as to be looked on as wonders.

This white eagle had been probably bred on some of the wild rocky headlands of the north coast of Sutherlandshire, where not even the value of the eggs can at all times induce the shepherds of the neighbourhood to attempt their capture. The seaeagle is, in its habits, a sluggish, vulture-like bird, feeding chiefly on the dead fish and other animal substances which are cast up by the sea on these lonely and rugged shores, and seldom attacking the lambs of the farmer to the same extent as the golden eagle does. Although it is frequently seen, and its sharp bark-like cry is heard far inland, the usual hunting-ground of the sea-eagle is along the shore, 
where it can feed on its foul prey, undisturbed and unseen by human eye for months together. Like the golden eagle, this bird sometimes so gorges itself with food as to become helpless, and if then met with, may be knocked down by a stick, or captured alive before it can rise from the ground - a sad and ignoble fate for the king of birds : After all, the eagle is but a sorry representative of royalty and kingly grandeur; for although his flight is noble and magnificent, and his strength and power astonishing, there is a cruelty and treachery about the disposition of the bird which render it unfit to be educated and trained like the peregrine and other falcons; nor does it ever become attached to its keeper.

On the 28 th of September the last house-swallow took his departure from this neighbourhood, although the season was so fine that there were several nests of young greenfinches about the garden even so late as the 30 th of the month, and a wood-pigeon was sitting on its eggs in an ash-tree close to the house.

During the latter weeks of the fishing season (which legally ends on the 15 th of September in all the northern rivers), the lower pools of the Findhorn are full of an excellent small sea-trout, locally called the finnock. My opinion is that the VOL. I. 
"finnock" is the grilse, or young of the common sea-trout, bearing exactly the same relation and affinity to that fish as the grilse does to the salmon; but the natural history of the inhabitants of another element is too uncertain and difficult a subject for a mere casual observer to enter upon. At any rate, the finnock is not only an excellent fish for the table, but affords capital sport, rising freely, and playing boldly when hooked; and has altogether strong attractions for those anglers who somewhat love their ease. I have been much amused by seeing an elderly, placid-looking London gentleman, who was staying at Forres for the purpose of fishing in the Findhorn. This old gentleman used to arrive at the river's edge at a comfortable noon-day hour, accompanied by his lady, and a footman splendid in blue and red, who carried camp-stools, books, fishing-tackle, and last, though not least, a most voluminous luncheon. Daily did this party make their appearance at a certain pool ; and while the old gentleman, seated at his ease on his camp-stool close to the water, with spectacles and broad-brimmed hat, fished away with the wellknown perseverance and skill of a Thames angler, his lady read her book on one side, whilst on the other the red-legged footman either prepared the luncheon, or held in readiness the well-stocked fly- 
book of his master. Very different would be the description given of our Scotch fishing by one who thus practised the gentle craft of angling on the level grassy banks of the lower pools of the Findhorn, to that of the sportsman who followed up the pursuit of the salmon over the rugged, and often dangerous, passes of the rocks which overhang the deep black pools and rushing torrents of the same river between Dulsie Bridge and the Heronry.

Most of the roebucks have, by the end of September, put on their winter covering of rich mouse-coloured hair; so different from the thin red coat they wear during the summer. Until they have quite changed colour the roe are not in sufficiently good condition to make them a fit object of pursuit for the sportsman. The stag is, however, in perfection both as to condition and beauty, during this month.

The size of the horns of the red-deer depends to a certain degree on the feeding which the animal gets in the spring and end of winter. If his food has been poor, and if he is much reduced, the horns do not acquire their full development and size. Fine heads of horns are now much rarer than they were a few years ago. The reason of this probably is, that the stag before it attains a mature age generally falls a victim to one of the numerous English 
rifles, whose echoes are heard in almost every Highland corrie. Even where deer are most carefully preserved and most numerous, the finest antlers are generally laid low every season; so that there are few left whose heads are thought worthy of being kept as a trophy: yet small as they now comparatively are, the value of a stag seems to depend more on his horns than on his haunches.

I am much inclined to think that the uncertainty of getting a shot at deer in wood is even greater than on the open mountain. The cunning of the animals, and dislike to being driven in any one direction, frequently render abortive the best arranged plans for beating a cover. Sometimes the deer are off at the first sound of a beater, at another time they will lie quietly without moving till all the men have passed them, and will then sneak quietly back in the contrary direction.

I was this very year particularly struck with an instance of deer escaping in this manner. I was placed with a friend on passes commanding the extremity of a long narrow patch of cover which grew on a steep brae overhanging a beautiful river in Ross-shire ; and the beaters were to commence their work at the other extremity of the wood. We had taken our stations at a considerable height above the river, at the most likely pass for the deer 
to leave the wood by ; there we waited some time without seeing anything excepting an occasional blackcock or gray hen, which, having been disturbed by the beaters at the other end of the cover, came skimming rapidly past us. Presently we perceived far below us four brown forms walking slowly through the high fern and herbage which grew amongst the birch-trees. As they emerged from the cover we saw that they were three hinds and a calf. With uncertain pace they went on, sometimes trotting in a line, and sometimes standing in a group on some hillock, from which they looked back earnestly and inquiringly into the wood. I was convinced by their manner that there were other deer, probably stags, still in the cover. As, however, the sound of the beaters came nearer, the four deer gradually mended their pace, and in a quiet canter followed the devious track which led them to the summit of a steep hill to our right hand. It was interesting to see how, having once made up their mind as to their route, they went steadily and rapidly on in single file, winding up the face of the hill, sometimes lost to our sight behind a cluster of rocks, or a birch-covered hillock, and again appearing as they kept deliberately on their way. At the very ridge of the hill they halted again, and after standing in a confused group with their heads 
all together, and their long ears at full stretch, they at once disappeared from our sight.

The beaters came closer and closer to us, and in spite of my prognostications no more deer appeared. At last the men issued out of the wood, at the point nearest us; and one of them came up towards where we were, to call us down. A drizzly shower had commenced, and we had put the gun-covers on our rifles, when suddenly from under a single birch-tree, which was about fifty yards from us, and about the same distance from the beater, rose a magnificent stag, in the finest condition, and with "a head of ten." Before we could get out our rifles he was behind a rise in the ground which concealed him from us until he was too far for a ball to reach him; and then he again appeared galloping heavily off for the same point at which the hinds had crossed the hill. We were both of us dumb with surprise and vexation; but not so the Highlander below us, who, in the most frantic state of eagerness and rage, hallooed and vociferated in Gaelic and English, for the stag passed, with broadside on, within forty yards of him. Without moving from our position we watched the animal for some time; then, returning our rifles to their waterproof cases, we, as if by a common impulse, lit the pipe of consolation in the shape of 
a cigar. Whilst so employed, with our heads bent from the cold misty blast, we again heard the man below us shouting more frantically than before, and looking up we were just in time to see him fling his stick at another stag, who had risen from the same spot and had cantered away in a contrary direction, passing almost close to the beater. Like the first stag, too, he managed to keep his great body out of our view as long as within shot, although he almost ran round the man, as if perfectly understanding the difference between two double-barrelled rifles and one walking-stick. We afterwards ascertained that the two deer had been lying in a small hollow of the ground at the foot of a single birch-tree, which stood a little in advance of the main wood. They must have been lying with their heads close to the ground, hoping to escape being seen; and there they remained until they perceived that the beater as well as ourselves was walking directly towards them.

In taking up a position near a wood which the men are about to beat for deer and roe, the sportsman should go as cautiously and quietly as if he was stalking a deer on the open hill, as nothing will drive either stag or buck near a spot where he has discovered or suspected that any concealed danger is awaiting him: rather than do so, he will pass 
within reach of the sticks of the beaters, having, like human beings, a far greater dread of an unknown danger than of one which he sees and knows the full extent of; and like many people taking "omne ignotum pro horribili."

Though red-deer seldom come down to the woods in this immediate neighbourhood, I have occasionally seen one who has probably wandered away from the Duke of Richmond's forest.

Instances, too, sometimes occur of a stag being found in the act of swimming narrow parts of the Moray Firth;- - a solitary deer, who probably has been driven by dogs from his usual haunts, till, frightened and bewildered, he has wandered at random; and at last, coming to the shore, has swam boldly out, attracted by the appearance of the woods on the opposite side.

END OF VOL. I. 


\section{LIST OF BOOKS}

\section{PUBLISHED BY DAVID DOUGLAS.}

\section{ADAMSON-On the Philosophy of Kant.}

By Robert Adanson, M.A., Professor of Logic and Mental Philosophy, Owens College; formerly Examiner in Plilosophy in the University of Edinburgh. Ex. feap. Svo, $6 \mathrm{~s}$.

"Within less than two hundred pages they convey to the intelligent reader a fair knowledge of Kant's method and doetrines. The notes indicate wide reading, and form an admirable appendix to the text."-Theological Quarterly.

\section{AGNEW-The Correspondence of Sir Patrick Waus of}

Barnbarroch, during the latter half of the Sixteenth Contury, from originals in the Family Charter-Chest. Edited by R. VAns AGNEW. 1 vol. demy Svo, $21 \mathrm{~s}$.

\section{ALDRICH-Ponkapog to Pesth.}

By Thomas BAlLeY ALDRich, $\boldsymbol{A}$ uthor of "Marjorie Daw."

[In the Press.

\section{ALEXANDER-Johnny Gibb of Gushetneuk in the Parish} of Pyketillim, with Glimpses of Parish Politics abont A.D. 1843. By William Alexasider. Sixth Edition, with Glossary, ex. feap. Svo, 2s.

Seventh Edition, with Twenty Illustrations - Portraits and Landscapes-by GEORGE REID, R.S.A. Demy Sro, 10s, bid.

"A most vigorous and truthful delineation of local character, drawn from a portion of the country where that charaeter is peculiarly wortlyy of careful study and record."-The Right Hon. W. E. Gladstone.

"It is a grand addition to our pure Scottish dialect; . . . it is not merely a eapital specimen of genuine Scottish northern dialect; but it is a capital specimen of rawky characteristic Scottish humour. It is fnll of good hard Scottish dry fun."-Dean Rainsay.

\section{ALEXANDER-Life among my Ain Folk.}

1. Mary Malcolmason's Wee Maggie.

2 Couper sandy.

3. Francie Herriegerie's Sharger Laddie.

4. Baubie Huie's Bastard GeEt.

5. GLengiliodram.

Ex. fcap. Svo. Second Edition. Cloth, 2s. 6d. Paper, 2s.

" Mr. Alexander thoroughly uuderstancls the position of men and women who are too often treated with neglect, and graphically depicts their virtues and vices, and shows to his readers diftieulties, struggles, and leeds which they are sure to be the wiser for taking into riew."-Freeman.

" 'Baubie Huie's Bastard Geet,' which is full of quiet lut effective humour, is the clearest revelation we have ever seen of the feeling in Scoteln country district: in regarl to certain aspects of morality."-- spectator.

"We find it difficult to express the warm feelings of admiration with which we have read the present volume."-Aberdeen Journal.

"Done with a skilful and loving liand."-Daily Review. 


\section{ALEXANDER-Notes and Sketches of Northern Rural} Life in the Eighteenth Century, by the Author of "Johnny Gibb of Gushetneuk." Iu 1 vol. ex. fcap. Svo, 2s.

"This delightful little volume. It is a treasure. . . We admire the telling simplicity of the style, the sly, pawky, Aberdonian huruour, the wide acquaintance with the social and other conditions of the northern rural counties of last century, and the fund of illustrative anecdotes which enrich the volurue. The author has done great service to the cause of history and of progress. It is worth a great many folios of the old dry-as-rlust type."-Daily Roview.

\section{AMERICAN AUTHORS, Choice Editions of, in One} Shilling Vols.

\section{By W. D. HOWELLS.}

"Mr. Howells's novels are remarkable for delicacy of humour and consurumate skill in the delineation of character."-Truth.

A Foregone Conclusion.

A Chance Acquaintauce.

Their Wedding Journey.

A Couuterfeit Presentment.

Lady of the Aroostook. 2 vols.

By RICHARD GRANT WHITE.

Mr. Washiugton Adams in England.

By FRATK R. STOCKTON. Rudder Grange.

The Lady or the Tiger?

By GEORGE W. CABLE. Old Creole Days.

Out of the Question.

Undiscovered Country. 2 vols.

A Fearful Responsibility.

Venetian Life. 2 vols.

Italian Journeys. 2 vols.

By JOHN BURROUGHS.

Winter Sunshine. Wake-Robin.

Locusts and Wild Honey.

Pepactou. Birds and Poets.

By B. W. HOWARD.

One Sunmer.

By GEORGE WILLIAM CURTIS. Prue and I.

\section{BY OLIVER WENDELL HOLMES.}

The Autocrat of the Breakfast-Table, | The Poet. 2 vols.

2 vols.

The Professor. 2 vols.

By G. P. IAATHROP.

Au Echo of Passion.

By J. C. HARRIS (Uncle Renus). Hingo.

\section{ANDERSON-The Gallop.}

Others in Preparation.

By E. L. ANDerson. Illustrated by Instautaneous Photography. I vol. feap. 4 to, 2 s. $6 \mathrm{~d}$.

"Mr. E. L. Anderson has collected in a thin little book, admirably illustrated by Mr. Muybridge's system of photography, all that theory and practice can teach us as to how a horse should be trained to gallop."-Saturday Review.

"It cannot fail to be of value to the riding and sporting world."-American Register.

\section{ANDERSON-IIodern Horsemanship. A New Method of}

Teaching Riding and Training by means of pictures from the life. By E. L.

ANDERson. Illustrated by 28 Instantaneous Photographs. 1 vol. demy 8vo. 21s.

"A master of the craft."-Illustrated Sporting and Dramatic News.

"A practical and very accomplished horseman. The fact is obvious from his book."-Saturday Review.

"The book is liberally furnished with instantaneous photographs, which illustrate and explain the author's text."-St. Jumes's Gazette.

"Every detail connected with saddle, bits, and bridles, with mounting and leaping, is dealt with in the most thorough manner."-Harper's Magazine.

\section{ANDERSON-Scotland in Early Christian Times.}

By Joseph ANDERson, LL.D., Keeper of the National Museum of the Antiquaries of Scotland. 1 vol. demy 8vo, with Eighty-four Wood Eugravings, and Three Quarto Diagrams of Celtic Ornamentations. In 1 vol. demy Svo, price 12s. (Being the Rhiud Lectures in Archæology, 1879.) 
"We know of no work within the reach of all students so completely realising its professions, and we can conficlently recommend to the architect, artist, and antiquary, young and old, this volume on Celtic art in Scotland." - British Architect and Engineer.

"Mr. Anderson sets the facts forth with an accuracy too rare in works of this class, and arranges them in the light of principles that make many of them for the first time intelligible."-St. James's Gutzette.

\section{ANDERSON-Scotland in Early Christian Times.}

Second Series. Celtic Art. By Joseph Anderson, LL.D. 1 vol. demy Svo, price 12s. (Being the Rhind Lectures in Archæology, 18s0.)

"All interested in the development of art will find here much new material for reflection." -Westminster Review.

\section{ANDERSON-Scotland in Pagan Times. The Iron Age.}

By Joseph Anderson, LL. D. 1 vol. demy Sro, price 12s. (Being the Rhind Lectures in Archeology, 1881.)

\section{ARGYLL-Crofts and Farms in the Hebrides:}

Being an Account of the Management of an Island Estate for 130 Years. By the DUKE of ARGrLL. In demy 8 vo, 83 pages, price $1 \mathrm{~s}$.

\section{ARGYLI-Continuity and Catastrophes in Geology:}

An Address to the Edinburgh Geological Society on its Fiftieth Anniversary, 1st November 1SS3. By the Duke of ARgyll. Demy Svo, price 1s.

\section{ARMSTRONG -The History of Liddesdale, Eskdale, Ewes-} dale, Wauchopedale, and the Debateable Land. Part I. from the Twelfth Century to 1530. By Robert Bruce Arustrong. The edition is limited to 275 conies demy quarto, and 105 copies on large paper (10 inches by 13). With an Appendix of 70 poeuments, arranged in Chronological order down to 1566 . Tle selection has heen inade from private Charter-ehests, MS. collections in London and Edinburch, and rare printed works, and comprises Charters, Rent-rolls, Excerpts from the Accounts of the Lorl High Treasurer, Bonds of Manrent, Bonds for the Re-entry of Prisoners, Lists of Scottisl Borderers under English Assurance, Injuries inflicted by the English and by the Scottisl Borderers under English Assurance from September 1543 to Jume 1544, interesting Letters and a Military Report on the West Mareh of Scotland and Liddesdale by an English official, ete. etc.

The Volume is illustrated by Haps, Etclings, Lithographs, and Woodeuts, all of which - with the exception of Blaeu's Maps of Liddesdale and Eskdale, and the etchings of James IV., James V., and the Earl of Angus, by C. Lawrie-will either be from the author's drawings or wholly executed by hinself. The lithographs in colour include facsimiles of four interesting representations of Scottish Border Castles and Towns drawn between the years 1563 and 1566, Plates of Arms of the Lords of Liddesdale, of the Clans of the District, of Lindsay of Wauchope, also of the Seals of John Armstrong and William Elliot, ete. ete. Price 42s. and 84 s.

\section{BAITDON-Morning Clouds :}

Being divers Poems by H. B. BAILDoN, B.A. Cantab., Author of "Rosamund," ete. Ex. feap. $\delta$ vo, $5 \mathrm{~s}$.

"Their tremulons beauty, delicate fancies, and wealth of language, recall the poetry of Shelley."-Literary World.

\section{BAIUDON-First Fruits. 5s.}

\section{BAIIDON-Rosamund. $5 \mathrm{~s}$.}

\section{BELLAMY-Dr. Heidenhoff's Process.}

By Edward Bellamy. In 1 vol, crown 5 ro, $6 \mathrm{~s}$.

"Very pathetic and charming novelette."-Whitehall Review. 
BELLAMY - Miss Ludington's Sister : a Romance of “Immortality. By Edward Bellayy, Author of "Dr. Heidenhoff's Process." 1 vol. crown 8vo, 6s.

\section{BISHOP-The Voyage of the Paper Canoe.}

A Geograplical Journey of 2500 Miles, from Quebec to the Gulf of Mexico, during the year 18:-75. By N. H. Bishop. With Maps and Plates, demy Svo, 10s.6d.

"There are some capital stories in this book, with a racy American flavour; and Mr. Bishop especially shines in his delineation of the liberated and enfranchised negro."-Pall Mall Gazette.

\section{BLACKIE-Lyrical Poems.}

Crown 8vo, cloth, 7s. 6 d.

\section{BLACKIE-The Language and Literature of the Scottish} Highlands. In 1 vol. crown 8 vo, 6 s.

"The way to a mother's heart is throngh her children; the way to a people's heart is througl its language."-Jean Paul Richter.

" Ein Buch, das ich auch deutschen Lesern, und zwar in einem beträchtlich weitem Umfange, nicht angelegentlich genug empfehlen kann."-Dr. R. Pauli.

BLACKIE-Four Phases of Morals:

Socrates, Aristotle, Christianity, and Utilitarianism. Lectures delivered before the Royal Institution, London. Ex. feap. Svo, Second Edition, 5 s.

\section{BLACKIE-Songs of Religion and Life.}

Feap. Svo, 6s.

\section{BLACKIE-On Self-Culture :}

Intellectnal, Physical, and Moral. A Tade-Necum for Young Men and Students. Fourteenth Edition. Fcap. 8vo, 2s. 6d.

"Every parent should put it into the hands of his son."-Scotsman.

"Students in all countries would do well to take as their vale-mecum a little book on self-eulture by the eminent Professor of Greek in the University of Edinburgh."--1Fedical Press and Circular.

"An invaluable manual to be put into the lands of students and young men." - Era.

"Written in that lucid and nervous prose of which he is a master."-Spectator.

"An adequate guide to a generous, eager, and sensible life."-Academy.

"The volnme is a little thing, but it is a multum in parvo ... a little locket gemmed within aud without with real stones fitly set."-Courant.

\section{BLACKIE-On Greek Pronunciation.}

Demy 8vo, 3s. 6 d.

\section{BLACKIE-On Beauty.}

Crown 8vo, cloth, 8s. 6d.

"A useful and closely written book, fervid without being verbose, scientific without being dry ; and as amusing as it is valuable."-Athenceum.

BLACKIE-Musa Burschicosa.

A Book cf Songs for Students and University Men. Fcap. Svo, 2s. 6d.

BLACKIE-War Songs of the Germans.

Fcap. 8vo, price 2s. 6d. eloth; 2s. paper.

BLACKIE-Political Tracts.

Nin 1. Governmext. No. 2. Education. Price 1s. each. 


\section{BLACKIE-Gaelic Societies.}

Highland Depopulation and Land Law Reform. Demy 8vo, 6d.

\section{BLACKIE-Homer and the Iliad.}

In three Parts. 4 vols. demy 8 vo, price $42 \mathrm{~s}$.

\section{BOWEN-“"Verily, Verily," The Amens of Christ.}

By the Rev. Grorae Bowes of Bombay. Small 4to, cloth, 5 s.

"For private and devotional reading this book will be found very helpful and stimulative."-Literary World.

\section{BOWEN-Daily Meditations by Rev. G. Bowen of Bombay.}

With Introductory Notice by Rev. W. HANsa, D.D., Author of "The Last Day of our Lorl's Passion." New Edition, small 4to, cloth, 5s.

"Among such books we shall scarcely find another which exhibits the same freshness and vividness of idea, the same fervour of faith, the same intensity or devotion. ... I count it a privilege to introduce in this country a book so fitted to attract and to benefit." - Extract from Preface.

"These meditations are the production of a missionary whose mental history is very remarkable. ... His conversion to a religious life is undoubtedly one of the most remarkable on record. They are all distinguished by a tone of true piety, and are wholly free from a sectarian or controversial bias."-Morning Post.

\section{BROWN-Horæ Subsecivæ. First Series.}

By JoHN BRows, M.D. In I vol. crown svo. Fourtl Edition, with a Portrait by JAS. FAED, 7s. 6d. Containing-

Loeke and Sydenham.

Dr. Andrew Combe.

Dr. Henry Marshall and Military Hygiene.

Art and Science: A Contrasted Parallel.

Our Gideon Grays.

Dr. Andrew Brown and Sydenham.

Free Competition in Medicine.

"The whole volume is full of wit and wisdom. . . . It will be a medical classic like the "Religio Medici.".-Edinburgh Medical Journal.

\section{BROWN-Horæ Subsecivæ. Second Series.}

By Jons Brown, M.D. In 1 vol. crown 8ro. Eleventh Edition, 7s. 6d. Containing-

Letter to John Cairns, D.D.

Dr. Chalmers.

Dr. George Wilson.

Her Last Half-Crown.

Queen Mary's Child-Garden.
Elward Forbes.

Dr. Adams, of Banchory.

Henry Vaughan.

Exeursus Ethicus.

Professor Syme.

Dr. John Scott.

Sir Robert Christison.

Lectures on Healtli.

ATXINOIA - Nearness of the NORS-Presence of Mind-'ErsTOXIA: Happy Guessing.

The Black Dwarf s Bones.

$\mathrm{Rab}$ and his Friends.

"With Brains, Sir !"

Arthur H. Hallam.

" He speaks to us out of the riches of a storied past with all the charm of one who knew and loved it well; and his manner is so sympathetic, and his touch so gentle and exquisite, that we always feel he knows and loves the present with the truest and largest of hearts." - Litcrary World. 


\section{BROWN-Horæ Subsecivæ. Third Series.}

By John Brown, M.D. In 1 vol. crown Svo. Fourth Edition, with a Portrait by GEo. ReID, R.S.A., 7s. 6d. Containing-

John Leech.

A Jacobite Family.

Mystifications.

Miss Stirling Graliam of Duntrune.

Thackeray's Death.

Marjorie Fleming.

Minchmoor.

"In Clear Dreain and Solemn Vision."

Jeens the Doorkeeper.
Sir E. Landseer's Picture, “There's Life in the Old Dog Yet," etc.

The Enterkin.

The Duke of Athole.

Struall.

Dick Mili, or Cur, why?

E. V. K. to his Friend in Town.

Sir Henry Raeburn.

Something about a Well, With more of our Dogs.

“Dr. John Brown's humour, pathos, and geniality are acknowledged qualities. ... We end with a hearty recommendation of the book to readers of almost every variety of taste, for they will find here scores of stories which will make them laugh or shudder, or fcel a great disposition to cry."-Saturday Review.

"In this new volume of the 'Horæ Subsecivæe' Dr. John Brown has given us some more of his pleasaut and discursive essays on men and beasts."-Pall Mall Gazette.

"One very obvious characteristic of these papers is their appearance of ease and spontaneity. They impress us as the work of oue full of his subject and delighted with it."-Academy.

"With two exceptions the essays and sketches are all racy of the northern soil."-St. James's Gazette.

"The author of 'Rab and his Friends' has published a volume of stray papers in which many delightful glimpses will be found of old Edinburgh society."Dundee Advertiser.

"To see anotler work of Dr. Joln Brown is pleasant unto the eyes as to see the face of an old friend."-Scotsman.

"There is in almost every one of Dr. Brown's inimitable papers such an "eeriness' as befitteth best only the hours of darkness."-Spectator.

"He has not a little of Mr. Ruskin's love of nature, but his humour and his wide humau affections preserve him from the evils of over intensity."-Nonconformist.

"The author of 'Rab aud his Friends' has a place apart among contemporary essayists. His manner and his matter are alike peculiar to himself."-Athenoum.

Scparate Papers, extracted from "Horce Subsccivce."

\section{Rab and his Friends.}

With India-proof portrait of the Author after Faed, and seven India-proof Illustrations after Sir G. Harvey, Sir J. Noel Paton, Mrs. Blackburn, and G. Reid, R.S.A. Demy 4to, cloth, 9s.

"Written with a quiet, unaffected power, wortly of the pathetic and touching scene it describes."-Saturday Review.

"A quaint and touching story."-Athenceum.

"A veritable gem. It is true, simple, pathetic, and touched with an antique grace."-Fraser's Magazine.

IMarjorie Fleming: A Sketch. Being a Paper entitled "Pet Marjorie ; a Story of a Child's Life fifty years ago." New Edition, with Illus. trations. Small 4 to, $7 \mathrm{~s}$. 6d.

Rab and his Friends.

Cheap Illustrated Elition. Square 12mo, ornamental wrapper, $1 \mathrm{~s}$.

Rab and his Friends.

Sixty-fourth Thousand. Price 6 d.

Our Dogs.

Twentieth Thonsand. Price Gd. 
"With Brains, Sir!"

Serenth Thousand, Price 6d.

Minchmoor.

Tenth Thousand. Price 6d.

The Enterkin.

Seventh Thousand. Price 6d.

Jeems the Doorkeeper.

Twelfth Thousand. Price 6d.

Marjorie Flleming: A Sketch.

Sixteenth Thousand. Price 6 d.

Plain Words on Health.

Twenty-seventh Thousand. Price 6d.

Something about a Well: With more of our Dogs. Price 6d.

Arthur H. Hallam.

Price 2s. sewed; and 2s. 6d. cloth, gilt edges.

Supplementary Chapter to the Life of the Rev. John Brown, D.D. Second Edition. Price 2s.

\section{BROWN-The Capercaillie in Scotland.}

By J. A. Harvie Brown. Etchings on Copper, and Map illustrating the extension

of its range since its Restoration at Taymouth in 1837 and 1838. Demy Svo, 8s. 6d.

"To no one will it prove uninteresting, and to ornithologists and sportsmen it is specially inviting." -Dundee Advertiser.

"A carefully prepared and exhaustive monograph of the Capercaillie in Scotland, which ought to be perused by every proprietor of an estate, forester, and naturalist in the country." -Journal of Forestry.

BULLOCH - George Jamesone. The Scottish Vandyke. 1587 to 1644. By JoHN Bulloch. With Two Illustrations by GEorge Reid, R.S.A.

BURNETT_“The Red Book of Menteith" Reviewed.

[In the Press.

By George Burnett, Advocate, Lyon King of Arms. In 1 vol, sinall 4to, $5 \mathrm{~s}$.

BURROUGHS-Winter Sunshine.

By John Burroughs. 32mo, 1s., and cloth 2 s.

"The minuteuess of lis observation, the keenness of his perception, give him a real originality, and his sketches have a delightful oddity, viracity, and freshness."-The Nation (New York).

"It is full of amusing anecdotes and personal experiences."-Dundee Advertiser.

"Mr. Burroughs is one of the inost delightful of American essayists, steeped in culture to the finger ends, and 'Winter Sunshine' is one of his most delightful and agreeable volumes."-Pall Mall Gazette.

"It is not often granted to us to see ourselves as other see us quite so pleasantly as we do in Mr. Burroughs' nice little account of his trip to England."-Saturday Review.

\section{BURROUGHS-Locusts and Wild Honey.}

By JoHN BUrRougrs. 32mo, 1s.; and in Cloth, $2 \mathrm{~s}$.

"From beginning to end it is charming reading."-Westminster Reviev.

\section{BURROUGHS-Wake-Robin.}

$32 \mathrm{mo}, 1 \mathrm{~s}$. ; and in Cloth, $2 \mathrm{~s}$.

"These pages are fragrant with the fresh strong air of country life."-Freeman.

"His scenes are portrayed with the minuteness and accuracy of a photograph."

-Westmoreland Gazette. 


\section{BURROUGHS-Pepacton and other Sketches.}

$32 \mathrm{mo}, 1 \mathrm{~s}$. ; and in Cloth, $2 \mathrm{~s}$.

"A book for holiday reading, or for that genial cvening hour when close-drawn curtains and a glowing fire draw a listening eircle to think of woods and wilds, with all their furred and feathered inhabitants."-Literary World.

\section{BURROUGHS-Birds and Poets, with other Papers.}

$32 \mathrm{mo}, 1 \mathrm{~s} . ;$ and in Cloth, $2 \mathrm{~s}$.

"There are few readers of American magazine literature who have not lingered with pleasure over pages in which Mr. Burroughs has discoursed of the cliarms of wood and field." - Gilasgow News.

CABIE-Dr. Sevier.

By GEo. W. CABLE, Author of "Old Creole Days," etc. In 2 vols. crown 8vo, price $12 \mathrm{~s}$.

\section{CABLE-Old Creole Days.}

By Geo. W. Cable. 32mo, 1s.; and in Clotl, 2s.

"With a good gift for language, and a very rare one for dialect, he has made a systematic study of Creole French, of which he may be regarded as the first thorough exponent."-Century.

"Another writer who has gained a great and well-deserved reputation in the United States is Mr. George W. Cable, who is doing for the State of Louisiana what Nathaniel Hawthorne did for New England-reproducing for us the people and customs of an age which, though not remote, has passed away."-Quarterly Review.

"The combination of grotesque humour and of genuine pathos is most charming, and quite unique and inimitable."-Glasgow Citizen.

"This collection, which includes sevelu stories, deserves to be read if only because it gives a picture of a phase of Southern life which has now passed away."-Saturday Review.

"We cannot recall any contemporary American writer of fiction who possesses some of the best gifts of the novelist in a higher degree."-St. James's Gazette.

"The book is one which when we have once begun we are constrained to finisll." -The Freeman.

\section{CAIRIS-Memoir of John Brown, D.D.}

By John Carras, D.D., Berwick-on-Tweed. Crown 8ro, 7s. 6 d.

\section{CAMPBELL-My Indian Journal.}

Containing Descriptions of the priucipal Field Sports of India, with Notes on the Natural History and Habits of the Wild Animals of the Country. By Colonel Walter CAMPEell, Author of "The Old Forest Ranger." Small demy 8vo, with Illustrations by Wolf, $16 \mathrm{~s}$.

\section{CHALMERS-Life and Works of Rev. Thomas Chalmers,}

D.D., LL.D.

Memoirs of the Rev. Thomas Chalmers. By Rev. W. Hanna, D.D., LL.D. New Edition. 2 vols. crown 8 vo, clotl, 12 s.

Daily Scripture Readings, Cheap Edition. 2 vols. crown 8vo, 10s.

Astronomical Discourses, is.

Commerctal Discourses, 1 s.

SELECT Works, in 12 vols. crown Svo, cloth, per vol. $6 \mathrm{~s}$.

Lectures on the Romans. 2 vols.

Sermons. 2 vols.

Natural Theology, Lectures on Butler's Analogy, etc. 1 vol.

Christian Evidences, Lectures on Paley's Evidences, etc. 1 vol.

Institutes of Theology. 2 vols.

Political Economy, with Cognate Essays. 1 vol.

Polity of a Nation. 1 vol.

Church and College Establishments. I vol.

Mforal Philosophy, Introductory Essays, Index, etc. 1 vol. 


\section{CHIENE-Lectures on Surgical Anatomy.}

By John Chmene, M.D., Prof. of Surgery in the University of Edinbargl. In 1 vol. demy svo. With numerous illustrations drawn on Stone by BerJeaU. 12s.6d.

"Dr. Chiene has snceeeded in going over the most important part of the gronnd, and in a pleasant readable manner. . . They (the plates) are well exeented, and considerably enhance the value of the book."-Lancet.

"The book will be a great help to both teachers and taught, and students can depend mpon the teaching as being sound."-Medical Times and Gezette.

\section{CHIENE-Lectures on the Elements or First Principles of} Surgery. By John Chiene, M.D., Prof. of Surgery in the University of Edinbnrgh. Deiny 8vo, 2s. 6d.

\section{CHRISTIE-Traditional Ballad Airs.}

Arranged and Harmonised for the Pianoforte and Harmoninm. By W. Christie, M.A., and the late Willia Christie, Monquhitter. Demy 4to, Vols. I. and II. 42s. each.

"As a contribntion to onr national stories it takes rank perhaps even above Dean Ramsay's popular 'Reminiscences of Scottish Life and Character.'"-Inver. ness Couvier.

CONSTABLE-Archibald Constable and his Literary Correspondents: a Memorial. By his Son, Thomas Constable. 3 vols. demy Sro, 30s., with Portrait.

"He (Mr. Constable) was a genius in the publishing world. . . . The ereator of the Scottish publishing trade."-Times.

"These three volnmes are of a singnlar and lasting interest."-Nonconformist.

CRAWFORD - The Earldom of Mar, in Sunshine and in Shade, during Five IIundred Years. With incilental Notices of the leading Cases of scottish Dignities of King Charles 1. till now. By ALExander, Earl of Crawford and Balcarres, Lord LixDsar, etc. etc. 2 vols. demy svo, 32s,

"It is one of the most learned ex]rositions of peerage history and peerage law, which it has been our fortune to tind." - Morning Post.

\section{The Crime of Henry Vane: a Study with a Moral.}

By J. S., of Dale, Anthor of "Gnerndale." In 1 vol. cruwn Svo, 6s.

"A man's book for" one thing, and it is a manly book for another. It is a singnlar story, more direct and bolder than 'Gnerndale." - Saturdoy Feview.

CROOM-A Chinical and Experimental Study of the Bladder dming Parturition. By J. H. Croos, II.B., F.R.C.P.E. Small 4to, with Illustrations, $6 \mathrm{~s}$.

\section{CUMMING-Wild Men and Wild Beasts.}

Adventures in Camp and Jungle. By Lient.-Colonel Gordon Cuming. With Illustrations by Lieut.-Col. BAlgrie and others. Second Edition. Sinall 4to, price $24 \mathrm{~s}$.

Also, a cheaper edition, with Lithographic Illustrations. 8vo, 12s.

\section{CURTIS-Prue and I.}

By George Willia Cortis. In 1 vol., 1s. paper; or 2s. cloth extra.

"This is a dainty piece of work and well deserved reprinting."-Athenceum.

\section{DASENT-Burnt Nja?.}

From the Icelandic of the Njal's Saga. By Sir George Webee Dasext, D.C.L.

2 vols. demy 8vo, with Mrps and Plans, 2Ss. 


\section{DASENT-Gisli the Outlaw.}

From the Icelandic. By Sir George Webe Dasext, D.C.L. Small 4to, with Illustrations, 7s. $6 \mathrm{~d}$.

\section{DASENT-Tales from the Norse.}

By Sir George Webre Dasent, D.C.L. Third Edition, with Introduction and Appendix. In 1 vol. demy Sro.

[In the Press.

\section{A Daughter of the Philistines: A Novel.}

1 vol. small crown 8 vo, 6 s.

"The story is very powerfully told, possesses a piquantly satirical flarour, and possesses the very real attraction of freshness."-Scotsman.

"It is cleverly and brightly writteu."-Academy.

DAY - The Uses and Manufacture of Iron and Steel, from Prehistoric Ages to the Present Time. By St. John V. DAY, C.E., F.R.S.E., F.S.A. (Scot.), Member of the Iron and Steel Institute, Member of the Institution of Mechanical Engineers, Associate of the Institution of Civil Engineers, Member of Council of the Institute of Patent Agents, etc. To be completed in 3 vols. demy 8 vo. (Vol. I. in October.)

[In the Press.

\section{DITTMAR - A Manual of Chemical Analysis.}

By Professor William Dittmar. Ex. feap. Svo, 5s.

\section{DITTMAR-Tables forming an Appendix to Ditto.}

Demy Svo, 3s. 6d.

\section{DUN-Veterinary Medicines; their Actions and Uses.}

By Finlay Dun. Sixth Edition, revised and enlarged. Demy 8vo, $15 \mathrm{~s}$.

\section{DUNBAR - Social Life in Former Days;}

Chiefly in the Province of Moray. Illustrated by Letters and Family Papers. By E. Dunbar Dunbar, late Captain 21 st Fusiliers. 2 vols. demy 8vo, 19s. 6 d.

\section{ERSKINE-Letters of Thomas Erskine of Linlathen.}

Edited by William Hanna, D.D., Author of the "Memoirs of Dr. Chalmers," ete. Fourth Elition. Iu 1 vol. erown Svo, 7s, 6d.

"Here is one who speaks out of the fulness of a large living human heart; whose words will awaken an echo in the hearts of many burdened with the cares of time, perplexed with the movements of the spirit of our time, who will speak to their deepest nceds, and lear them to a haven of rest."-Duily Review.

"It does one good to come in contact with so saintly a man, and Dr. Hanna has certainly conferred a benefit on the Church at large by editing this volume."Edinburgh Courant.

"'How high must that neak have been which caught the light so early,' were the words with which a writer in the Contemporary Review, in sketching the life of Thomas Erskine, shortly after his death, characterised his position, his spirit, and his influence."-Nonconformist.

ERSKINE-The Unconditional Freeness of the Gospel.

New Edition, revised. Crown Svo, 3s. 6d.

ERSKINE-The Brazen Serpent:

Or, Life coming throngh Death. Third Edition. Crown Sro, 5s. 
ERSKINE-The Internal Evidence of Revealed Religion.

Crown Svo, 5s.

"Before Mr. Erskine went abroad in 1S22, he published his first work on "The Internal Evidence of Revealed Religion,' in which he pursued in a more extended manner something of the same line of thought as that already spoken of. II is Great alM WAS TO SHOW THE DIMNE ORIGIN OF CHRISTIANity BOth FroN THE FITTING ILLUSTRation WHICH IT FURNISHED OF THE CHARACTER OF GOD AND ITS BEARING ON THE CHARACTER OF MAN, to demonstrate that its facts not only present an impressive exhibition of all the moral qualities which can be conceived to reside in the Divine mind, but also contain all those objects which have a natural tendency to excite and suggest in the human mind that combination of moral feelings which has been termed moral perfection."-Edinburgh Review.

\section{FRSKINE-The Spiritual Order,}

And other Papers selected from the MSS. of the late THomas ERskiNe of Linlathen. Second Edition. Crown Svo, 5s.

"It will for a few have a value which otlers will not the least understand. But all must recognise in it the utterance of a spirit profoundly penetrated with the sense of brotlierhood, and with the clainis of common humanity."-Spectator.

"Very deserving of study."-Times.

Vide Bible Readngs and Fraguents of Truth.

ERSKINE-The Doctrine of Election,

And its Connection with the General Tenor of Christianity, illustrated especially from the Epistle to the Romans. Second Edition. Crown Svo, 6s.

\section{FAITHFULL-Three Visits to America.}

By Emily Faithfull. Demy 8 ro, $9 \mathrm{~s}$.

FERGUSON - Guide to the Great North of Scotland Railway. By W. Ferauson of Kinmundy. In 1 rol. crown Svo; in paper cover, 1s.; cloth cover, 1s, 6d.

"An extremely rcadable and amusing, as well as instructive, little volume."Abcrdeen Free Press.

FERGUSON - Twelve Sketches of Scenery and Antiquities on the Line of the Great North of Scotland Railway. By George ReID, R.S.A. With Illustrative Letterpress by W. FERGuson of Kimmundy. 4to, 15s.

\section{FERGUSSON-Letters and Journals of Mrs. Calderwood} of Polton, from England, Holland, and the Low Countries, in 1756. Edited by Alex. Feraussos, Lientenant-Colonel, Author of "Henry Erskine and his Kinsfolk." Demy svo.

\section{FLETCHER-Autobiography of Mrs. Fletcher}

(of Edinburgh), with Letters and other Family Memorials. Edited by her Daughter. Third Edition. Crown Svo, 7s. 6d.

"This is a delightful book. It contains an illustrative record of a singularly noble, true, pure, prolonged, and happy life. The story is recourized with a candour, vivacity, and grace which are very charming."-Daily Review.

\section{FLEURY-L'Histoire de France.}

Par M. Laßé Fleury. New Edition, corrected to 1S83. 1SMo, cloth, 2s, 6d.

FORBES-The Deepening of the Spiritual Life.

By A. P. Forbes, D.C.L., Bishop of Brechin. Fifth Edition. Calf, red edges, 3s.6d. 


\section{FORBES-Kalendars of Scottish Saints,}

With Personal Notices of those of Alba, ete. By Alexander Pexrose Forbes, D.C.L., Bishop of Brechin. 1 vol. 4 to, price $£ 3: 3 \mathrm{~s}$. A few copies for sale on large paper, $£ 5: 15: 6$.

"A truly valuable contribution to the archæology of Scotland."-Guardian.

"We must not forget to thank the author for the great amount of information he has put together, and for the labour he has bestowed on a work which can never be remunerative." - Saturday Revieu.

"His laborious and very interesting work on the early Saints of Alba, Laudonia and Stratlicljde."-Quarterly Review.

FORBES-Missale Drummondiense. The Ancient Irish Missal in the possession of the Baroness Willoughby d'Eresby. Edited by the Rev. G. H. Forbes. Half-moroceo, demy Svo, 12s.

\section{Fragments of Truth:}

Beiug the Exposition of several Passages of Scripture. Third Edition. Extra feap. 8 vo, 5 s.

\section{FRASER-Alcohol: its Function and Place.}

By Thomas R. Fraser, M.D., F.R.S., Professor of Materia Medica in the University of Edinburgh. With Diagrams and Tables. Svo, 1s.

\section{GAIRDNER and SPEDDING-Studies in English History.}

By James Gairdner and Jasres Speddivg. Iu 1 vol. demy 8vo, 12s.

1. The Lollards.

2. Sir John Falstaff. '

3. Katherine of Arragox's First and Second Marriages.

4. Case of Sir Thomas Overbury.

5. Divine Right of Kings.

6. SUNDAY, AYCIENT AND MODERN.

"The authors' names alone are a suffieient guarantee that the Essays in this beautifully priuted voluuc were worth reprinting." - St. Jemes's Guzette.

"It will enlighten the realers on some points in respect to which they are at present very much in the dark." - Seotsman.

\section{GAIRDNER-On Medicine and Medical Education.}

By W. T. Galndxe, Professor of the Practice of Melicine in the University of Glasgow. Three Lectures, with Notes and an Appendix. Svo, 3s. 6d.

GAIRDNER-Clinical and Pathological Notes on Periearditis. By W. T. Garrdere, Professor of the Practice of Medicine iu the Uuiversity of Glasgrow. Svo, sewed, ls.

\section{Gifts for Men.}

By X. H. Crown Svo, 6 s.

"There is hardly a hiving theologian who might uot be proud to claim many of her thoughts as his owu."-Glatgow Herchl.

\section{GILFILLAN-Sketches Literary and Theological :}

Being selections from the unpublished MSS. of the Rev. George Gilfildax. Edited by Frank Hexderson, Esq., M.P. 7s. 6i.

"The papers chosen for publication are chiefly eritical, and they form a most readable, instructive, aud interestinct voluue."-Dundee Alvertiser. 


\section{GORDON-The Roof of the World:}

Being the Narrative of a Journey over the High Platean of Tibet to the Russian Frontier, and the Oxus Sourees on Pamir. By Lieut.-Col. T. E. Gordon, C.S.I. With numerous Illustrations. Royal 8 vo, 31s. $6 \mathrm{~d}$.

\section{GORDON-The Home Life of Sir David Brewster.}

By his Danghter, Mrs. Gordon. Second Edition. Crown Svo, 6s.

"With his own countrymen it is sure of a weleome, and to the savants of Europe, and of the New World, it will have a real and special interest of its own."-Pall Mall Gazette.

Also a cheaper Edition, crown 8 vo, 2s. 6 d.

GORDON-Workers.

\section{By the same Author.}

Fourth Thousand. Feap. Svo, limp cloth, 1s.

\section{GORDON-Work;}

Or, Plenty to do and How to do it. Thirty-sixth Thousand. Feap. 8vo, cloth, 2s. 6d.

Warfare Work.

Everyday Work.

Social Work.

Home Work.

Single Women's Work.

Waiting Work.

Preparatory Work.

Desultory Work.

Praising Work.

Special Work.

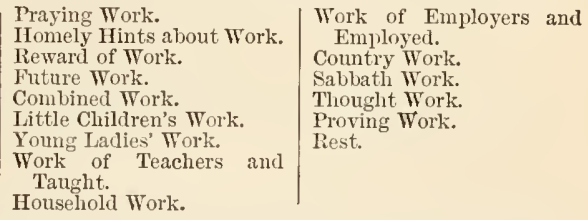

"Mrs. Gordon is precisely one of the ladies for the time,-not a drowsy dreamer, but fully awake, strong in heart, ardent in zeal, and intent on the vigorous use of right means to promote right ends."-British Benner.

"A better gift book for young domestic servants we do not know."-Literary Gazette.

\section{GORDON-Little Millie and her Four Places.}

Cheap Edition. Fifty-eighth Thousand. Limp cloth, 1s.

"The narrative is simple and attractive; the plan of the work is well conceived; the style is fluent and lively; and the interest of the tale is well sustained to the close."- Spectator.

\section{GORDON-Sunbeams in the Cottage;}

Or, What Women may do. A Narrative ehiefly addressed to the Working Classes. Cheap Edition. Forty-fifth Thonsand. Limp cloth, 1s.

"The fruit alike of strong sense and philanthropic genius. . . There is in every chapter much to instruct the mind as well as to monld the heart and to mend the manners. The volume has all the charms of romance, while every page is stamped with utility."-Christian Witness.

\section{GORDON-Prevention;}

Or, An Appeal to Economy and Common Sense. Sro, Gd.

GORDON-The Word and the World.

Twelfth Edition. Price 2d.

GORDON-Leaves of Healing for the Sick and Sorrowful.

Cheap Edition, limp cloth, 2s. 
GORDON-The Motherless Boy;

With an Illustration by Sir J. Noel Paton, R.S.A. Cheap Edition, limp cloth, 1s.

"Alike in manner and matter calculated to attract youthful attention, and to attract it by the best of all means-sympatly."--Scotsman.

\section{GORDON-Our Daughters :}

An Account of the Young Women's Christian Association and Institute Union. Price 2d.

GORDON-Hay Macdowall Grant of Arndilly; his Life, Labours, and Teaching. New and Cheaper Edition. 1 rol. crown svo, limp cloth, 2s. 6d.

HANNA-The Life of our Lord.

By the Rev. William Hansa, D.D., LL.D. 6 rols., handsomely bound in cloth extra, gilt edges, $30 \mathrm{~s}$.

Scparate vols, cloth extra, gilt edges, $5 \mathrm{~s}$. each.

1. THe Earlier Years of oUr Lord. Fifth Edition.

2. The Ministry in Galilee. Fourth Edition.

3. The Close of the Ministry. Sixth Thousand.

4. The Passion Week. Sixth Thousand.

5. The last Day of our Lord's Passion. Twenty-third Edition.

6. The Forty Days after the Resurrection. Eighth Edition.

"If Dr. Hanna excels in one thing more than another, it is in the simplicity of his style. It is this quality which gives beanty and force to the work before us. One cannot proceed far into the pages of this Life of our Lord without being struek with the unbroken continuity of movement illustrative of the life and work of Christ."-Christian Union.

HANNA-The Resurrection of the Dead.

By William Hanna, D.D., LL.D. Second Edition. One vol. fcap. Svo, 5s.

HARRIS - Mingo and other Sketches in Black and White. By Joel Chandlier Harris (Uncle Remus). 321no, 1s.; and in cloth, 2s.

HASTIE-Protestant Missions to the Heathen. A General Survey of their Present State throughout the World. By Prof. Th. Christlieb. Translated from the German by Rev. W. Hastie, Calcutta. 1 vol. demy 8vo, 1s.

\section{HASTIE-Elements of Philosophy.} Part First. 1s.

HASTIE-The Perpetuity of the Faith as our Ground of Hope. 1s.

HENDERSON-Notes of Caithness Family History.

By the late JoHn HeNDerson, W.S. 4to, 31s. 6d.

\section{HODGSON-Errors in the Use of English.}

Illustrated from the Writings of English Authors, from the Fourteentl Century to Our Own Time. By the late W. B. Hodgson, LL.D., Professor of Political Economy in the University of Edinburgh. Fourth Edition. 1 vol, crown 8vo, 3s. 6d.

"Those who most need such a book as Dr. Hodgson's will probably be the last to look into it. It will certainly amuse its readers, and will probably teach them a good cleal which they did not know, or at least never thought about, before."-The Saturday Review.

"Perhaps at no period in the history of our language was such a work as this needed so inuch as it is at present. . . . It would sare the feelings of many a lover of pure English were all forced, as a preliminary exercise, simply to read Professor Hodgson's collections of 'Errors in Englisl.' "-N.B. Daily Mail. 
"Beyond all doubt, Professor Hodgson has attained his object-viz. to set fortl the merits of correctness iu English composition by furnishing examples of the demerits of incorrectness-to bring home the abstract rule that a sentence must be lueid in order and logical in sequence."-The Athencum.

"This little volume will surely do excellent service, and we strongly recommend it for the study of all."-Manehester Examiner.

"This posthumous work of Dr. Iodgson's deserves a hearty welcome, for it is sure to do good service for the object it has in view."-The Academy.

"His conversation, as every one who had the pleasure of his acquaintance knows, sparkled with anecdote and epigram, and not a little of the lustre and charm of his talk shines out of those pages."-The Seotsman.

"The book is neither large nor expensive, but it contains a great aunount of careful and scholarly criticism."-Aberdeen Frce Press.

"No one who aims at a pure style of Englisl composition should be without this book." - The Educational News.

"As a help to composition this book will be found very useful, and to all it will prove a curious and interesting book for perusal." -Yorkishire Post.

HODGSON-Life and Letters of W. B. Hodgson, LL.D., late Professor of Political Economy in the University of Edinburgh. Edited by Professor J. M. D. MeinlejohN, M.A. 1 vol. crown Svo, 7s. 6d.

HOLE Character Portraits of the Professors of the University of Edinburgh. A series of Etchings by Dawsos, after Diawings by WiLLIAs HoLE, A.R.S.A. With brief Biographical Sketehes. Handmade paper, 4to, $£ 2: 2 \mathrm{~s}$. to Subscribers. A few copies on Large Paper. India Proofs, £5:5s. to Subscribers.

\section{HOLMES-The Autocrat of the Breakfast-Table.}

By Oliver Wendell Holmes. New and Revised Edition, containing fresl Preface and Bibliographical Notes by the Author. Printed at the Riverside Press. Crown 8vo, 10s. 6d.

\section{HOLMES-The Professor at the Breakfast-Table.}

New Edition. Crown Svo, 10s. 6d.

\section{HOLMES-The Poet at the Breakfast-Table.}

By Oliver Wexnell Holmes, M.D. New Edition, carefully Revised, with New Preface. Printed at the Riverside Press from New Electrotype Plates. With a Steel Portrait of the Author. Crown 8vo, 10s. 61.

"As he is everybody's favourite, there is no occasion for critics to meddle with him, either to censure or to praise. He can afforil to langh at the whole reviewing fraternity. His wit is all his own, so sly and tingling, but without a drop of illnature in it, and never leaving a sting belind. His humour is so grotesque and queer that it reminds one of the frolics of Puck; and deep pathos mingles with it so naturally that when the reader's eyes are brimming witl tears he knows not whether they have their source in sorrow or in laughter." - North American Review.

HOLMES-Pocket Edition of the Breakfast-Table Series in the Collection of Choice American Authors. 6 vols. $32 \mathrm{mo}$, 1s. each; or in clotl, gilt top, 2s. a vol. (in cloth box, 15s.)

HOME-Traces in Scotland of Ancient Water Lines, Marine, Lacustrine, and Fluviatile. By Darı MiLve-HoMe, LL.D., F.R.S.E. 1 rol. deniy $8 v o, 3 s .6 d$.

"To the student of geology and archæology the volume will present a compendium of precise and authentic observations, the importance of which cannot well be overrated, while for the general reader it contains a wonderfully interesting story of ceaseless change and vicissitude."-Glasgow Hercill. 
HOPE-A Sketch of the Life of George Hope of Fenton

Barns. Compiled by his Dadghter. 6s.

\section{HOWARD-One Summer.}

By Blanche Willis Howard. 32mo, paper, 1s. ; cloth, 1s. 6d. and 2s.

\section{HOWELLS-A IModern Instance: A Novel.}

Published with the sanction of the Author.

By W. D. Howells. Copyright Edition, in 2 vols. crown 8 vo, $12 \mathrm{~s}$.

"What interests us throughout is the vivid picture of American social life as it really is."-Spectator.

"In 'A Modern Instance' Mr. Howells is as pitiless as life itself. As a piece of artistic work it cannot easily be surpassed."-St. James's Gazette.

"Among the books which treat of the lives of Americans at home the most remarkable is the 'Modern Instance.' It is more powerful than any of Mr. Howells's previous works."-Blackwood's Magazine.

"No one can call this book either pious or didactic fiction, but we have seldom met with a nore religion-teaching book."-The Guardian (London).

" A Modern Instance' is before all things a study of character."-Athenceum.

\section{HOWELLS-Dr. Breen's Practice: A Novel.}

Copyright Edition, in 1 vol, crown Sro, 2s. 6d., or in cloth, 3s. $6 \mathrm{~d}$.

"In Dr. Breen's Practice we have an entertaining representation of modern American life, lightly and delicately touched off in Mr. Howells's peculiar style."Literary World.

\section{HOWELLS-A Woman's Reason: A Novel.}

Copyright Edition, in crown 8vo, 2 vols., 12s.

"This story will takc rank with the best ones of the season."-Literary World.

"Mr. Howells has worked up the old theme very pleasantly on this occasion, and flavoured it agreeably with a due share of the humour in which he decidedly has the advantage of Mr. Henry James."-Athencum.

"The reader is carried irresistibly to the end."-Nottingham Daily Guardian.

"In future Mr. Howells should be known as the author of $A$ Woman's Reason, for here alone he seems to have done justice to his singular powers. It is a real novel. We can only repeat how very excellent the book is, and how thoroughly worth reading-once, twice, and even thrice."-Academy.

\section{By the same Author and publishal with his sanction.}

Pocket Editions in One Shilling Volumcs. Caliso, 1s. 6d.; cloth gilt, 2s.

\section{HOWELLS-A Foregone Conclusion.}

"It is the greatest trimmph of the artist that out of material so little idealised he should have produced a story of such enduring and pathetic interest."-The Times.

\section{HOWELLS-Their Wedding Journey.}

"With just enough of story and dialogue to give to it the interest of a novel. It is also one of the most charming books of travel that we have ever seen." Christiun Register (Boston). 


\section{HOWELLS-A Chance Acquaintance.}

"The bright, courageous, light-hearted realism of the whole, the gay charm of the principal characters, the refined humour of some of the incidents, the sentiment and style in which the pretty sparkling story is, as it were, embedded, were such as showed a new artistic force at work, and amnounced a great and original talent."-The Times.

\section{HOWELLS-The Lady of the Aroostook.}

2 Vols. $2 \mathrm{~s}$.

"There are few more perfect stories than The Lady of the Aroostook:"-The Times.

\section{HOWFLLS - A Fearful Responsibility and Tonelli's} Marriage.

"The great body of the cultivated prublic has an instinctive delight in original genius, whetler it be refined or sensational. Mr. Howells's is eminently refined. His humour, however vivid in form, is subtle and elusive in its essence. He deleuds, perhaps, somewhat too much on the feeling of liumour in his readers to alpreciate his own."--E. P. Whipple.

\section{HOWELLS-The Undiscovered Country.}

2 Vols. 2s.

"The story is, like all Mr. Howells's creations, skilfully constructed and wrought out with careful elaboration of detail."-Frcemon.

\section{HOWELLS-A Counterfeit Presentment, a Comedy, and a} Parlour Car, a Faree.

"In this comedy Mr. Howells gives new proof of his rare insight into character, and ability to portray it by etfectire and discriminating touches, of his fine sense of dramatic scenes and incidents, and of lis exquisite literary skill."

\section{HOWELLS-Out of the Question, a Comedy, and At the} Sign of the Savage.

"We may safely prophesy that among the cultivated class of readers Mr. Howells's books will be in steady demand. There are already six or seven of them issued in a cheap form by the publisher of A Modern Instance. From our own knowledge we can recommeud A Chance Acquaintance and The Undiscovered country as books of careful workmanship and accurate observation, written from the American point of view, and without the least apparent influence, either in style or point of view, of English writers."-Saturday fieview.

\section{HOWELLS-Novels.}

These 10 vols., neatly bound in cloth gilt, in box, $21 \mathrm{~s}$.

HOWELLS-Venetian Life. 2 Vols. $2 \mathrm{~s}$.

"His facuity of shrewd, sympathetic observation possessed itself easily of Italian sights and characters, but through all the track of Venetian lagoons or Florentine streets one feels the racy American temper, nothing daunted by the old World. No description of Venice could be, as far as they go, more daintily, affectionately true."-Times.

\section{HOWELLS-Italian Journeys. 2 Vols. 2s.}

"Venctian Life and Italian Jonrneys are delightful reading, and they bear the promise of the future novelist in them. When he travelled in Italian towns he was studying human nature, and fortunately there have been preserved in these two books a vast number of little studies, minute observations, such as in abundance go to make the writer of fiction."-Century. 
IRVING-A Memorial Sketch and a Selection from the Letters of the late Lieut. JoHN IRving, R.N., of H.M.S. "Terror," in Sir John Franklin's Expedition to the Aretie Regions. Edited by BeNJanIn BELL, F.R.C.S.E. With Facsimiles of the Record and Irving's Medal and Map. 1 vol. post Svo, 5s.

Jack and Mrs. Brown, and other Stories.

By the Author of "Blindpits." 1 vol. crown 8vo, paper, 2s. 6d. ; cloth, 3s. 6d.

\section{JENKIN-Healthy Houses.}

By Fleeming Jenkin, F.R.S., Professor of Engincering in the University of Edinburgh, Demy 8vo, 2s. 6d.

"The three lectures will be found specially useful to the largely increasing class of house proprietors."-Courcht.

JERVISE-Epitaphs and Inscriptions from Burial-Grounds and Old Buildings in the North-East of Scotland. By the late ANDREw JERvise, F.S.A. Scot. With a Memoir of the Author. Vol. II. Cloth, small 4to, 32s.

Do.

do.

Roxburghe Edition, 42s.

JERVISE-The History and Traditions of the Land of the Lindsays in Angus and Mearns. New Edition, Edited and Revised by the Rev. JaMes Gamiack. In 1 vol. demy Svo. $14 \mathrm{~s}$.

Do. do. Large Paper Edition [of which only 50 are printed], demy 4to, Roxburghe binding, $42 \mathrm{~s}$.

"The editing of these remains has been very careful, and the book, though it has its arid tracts, is sure to please north country readers."

JOASS-A Brief Review of the Silver Question, 1871 to 1879. By Edward C. Joass, Fellow of the Faculty of Actuaries, Edin. Svo, 1s.

KENNEDY-Pilate's Question, "Whence art Thou?"

An Essay on the Personal Claims asserted by Jesus Christ, and how to account for them. By John Kennedy, M.A., D.D., London. Crown 8vo, 3s. 6 d.

"Written on a skilfully arranged plan, is unquestionably a powerfu and eloquent vindication of the orthodox and Catholic belief in opposition to rationalistic theories."-Scotsman.

\section{KER-Sermons by the Rev. John Ker, D.D., Glasgow.}

Twelfth Edition. Crown 8 vo, $6 \mathrm{~s}$.

"A very remarkable volume of sermons."-Contemporary Review.

"The sermons before us are of no common order; among a host of competitors they occupy a high class - we were about to say the highest class-whether viewed in point of composition, or thought, or treatment." $-B$. and $F$. Evangelical Review.

KNIGHT-The English Lake District as interpreted in the Poems of Wordsworth. By William KNight, Professor of Moral Philosophy in the University of St. Andrews. Ex. feap. Svo, $5 \mathrm{~s}$.

\section{KNIGHT-Colloquia Peripatetica (Deep Sea Soundings):}

Being Notes of Conversations with the late John Duncan, LL.D., Professor of Hebrew in the New College, Edinburgh. By William Kinight, Professor of Moral Philosophy in the University of St. Andrews. Fifth Edition, enlarged. 5s.

"Since these lectures were published there has appeared an exceedingly interesting volume entitled 'Colloquia Peripatetica,' by the late John Duncan, LL.D., Professor of Hebrew in the New College, Edinburgh. These Colloquies are reported by the Rev. Wm. Knight, who seems to be admirably adapted for the task he has undertaken. His friend must have been a man of rare originality, varied culture, great vigour in expressing thoughts which were worthy to be expressed and re- 
membered. - . The reader who shall give himself the benefit and gratification of studying this short volume (it will suggest more to him than many of ten times its size) will fiud that 1 have not been briberl to speak well of it by any praise which Dr. Duncan has bestowed on me. The only excuse for alluding to it is, that it contains the severest censure on my writings which they have ever incurred, though they have not been so unfortunate as to escape censure. . . . Against any ordinary criticism, even a writer who is naturally thin-skinner becomes by degrees tolerably hardelled. One proceeding from a man of such learning and worth as Dr. Duncan I have thought it a duty to notice." - Extract from Prefuce to "The Conscience." By the late Professor F. D. Naurice, Second Edition, 1872.

LAING-Lindores Abbey, and the Burgh of Newburgh; Their History and Annals. By Alexander latwg, LL.D., F.S.A. Scot. 1 vol. small 4to. With Index, and thirteen Full-page and ten Woodcut Illustrations, 21s.

"This is a charming volume in every respect."-Notes and Queries.

"The prominent characteristics of the work are its exhaustiveness and the thoroughly philosophic spirit in which it is written."-Scotsman.

LAING-Triumphs of Christianity illustrated by History.

A Lecture by Alexander LAixg, LL.D. Crown Sro, 1s.

LANMAN-Recollections of Curious Characters and Pleasant Places. By Charles Lanman, Washington; Author of "Adventures in the Wilus of America," "A Canoe Voyage up the Mississippi," "A Tour to the River Saguenay," etc. etc. In 1 vol. small demy $8 v 0,12 \mathrm{~s}$.

The Wizard of Anticosti.

Forest Recollections.

The Hunters of the Sea Elephant.

Around Cape Horn.

Montauk Point.

Salmon-Fishing on the Jacques Cartier.

"It is not unpleasant to be sometimes reminded by the appearance of a book of travel, written with greater fidelity and wider knowledge than is usually found, how little we know of the world and how large it really is. 11 . Lamman conscientiously notes down all that he has seen and what he knows."-Saturday Reviev.

"A bundle of delightful reminiscences touched with that light and graceful hand which is common to all his type."-Academy.

\section{IANCASTER-Essays and Reviews.}

By the late Henry H. Lancaster, Advocate; with a Prefatory Notice by the Rev. B. Jowetr, Master of Balliol College, Oxford. Demy Svo, with Portrait, 14s.

\section{IATHROP - An Echo of Passion.}

By Geo. Parsoxs Lathrop. 32mo, 1s. ; and in cloth, $2 \mathrm{~s}$.

\section{LAURIE-On the Philosophy of Ethics. An Analytical}

Essay. By S. S. LAurie, A.M., F.R.S.E., Professor of the Theory, History, and Practice of Edueation in the University of Edinburgh. Demy svo, 6 .

"Mr. Laurie's volume now before us is in substance, though not in form, a reply to Mr. Mill's Utilitarianism. Mr. Laurie has the metaphysical head and the metaphysical training of his countrymen, and has brought both to bear with great force on the problem proposed."-Saturday Review.

\section{LAURIE-Notes on British Theories of Morals.}

Demy Svo, 6s.

" $\mathrm{His}$ criticisms are candid and highly instructive, e.g. those of the views of Bentham, Mill, and Bain. He manifests great aptitude in detecting radical dcfects, in exposing logical inconsistencies, and in detecting the legitimate tendencies of philosophical systems."-British Quarterly. 


\section{LORIMER-Bible Studies in Life and Truth.}

By the Rev. Robert Lorimer, M.A., Free Church, Mains and Strathmartine. In 1 vol. crown 8 vo, 5 s.

"It is in several respects a remarkable volume. . . . These discourses, the outcome of a thoughtful, earnest, and vigorous mind, are written in a strain of chaste and manly eloquence, and they are even more valuable for what they suggest than for what they directly teach."-Scotsman.

"There is in these studies much that will help to govern the will, satisfy the mind with trutl, and the heart with life."-Daily Review.

"The distinctive fragrance of the old evangelical preaching of our fathers is combined with the modern spirit of exact research in Biblical science ... and these studies may be regarded as a proof that the reconciliation between the old and the new in our Scottish Christian life is not so difficult as some suppose."Aberdeen Free Press.

"On every line of these sermons there is a trace of care and anxious thought. This preacher is no extempore orator. He is a student, and has made hinself familiar with the best models."-Dundce Advertiser.

"They are characterised by penetrative thouglit, lucidity, and cogency of statement, and a chaste and classic eloquence. They evince earnest study and wide reading."-Glasgow Herctl.

\section{LIND-Sermons.}

By Rev. AdAm Lind, M.A., Elgin. Ex. fcap. 8vo, 5s.

\section{A Lost Battle.}

A Novel. 2 vols. Crown 8 vo, 17 s.

"This in every way remarkable novel."-Morning Post.

"We are all the more ready to do justice to the excellence of the author's drawing of characters."-Athenoum.

\section{M'CRIE-John Calvin, a Fragment by the Late Thomas} I'Crie, Author of "The Life of John Knox." Demy Svo, 6s.

\section{MACDUFF-The Parish of Taxwood, and some of its Older}

Memories. By Rev. J. R. Macduff, D.D. 1 vol. extra fcap. Svo, illustrated, 3s. $6 \mathrm{~d}$.

"A deliglitful little volume, as true to the life as it is picturesque in its subjects. . . We shall be inclined to add this unpretentious volume to the standard authorities on these favourite subjects. . . Unpretending as the pictures may be, to paint these worthy people to the life demands no little shrewdness of observation, considerable power of mental analysis, with a combination of rarer faculties. In the pictures we have quaint drollery as well as kindly satire; and while each has some fascination of its own, one at least is wonderfully pathetic. ... We think we have said enough to send our readers to a book which, while showing unusual powers of observation, is written with equal simplicity and deep earnestness of feeling."-Saturday Review.

"It is charmingly written, and deserves to be popular on both sides of the Tweed."-Liverpool Mfercury.

"This is the sort of book which is sure to be popular and warmly appreciated by Scotchmen, whether at home or in the colonies."-Perthshire Constitutional.

"Dr. Macduff has given us a specially delightful and instructive volume, a series of character sketches which are sure to live, and of memories which readers who can appreciate solid worth will not willingly let die. Shrewd, practical sense, kindly humour, and quiet sareasm add to the liveliness of a work which will be equally valued for its lofty devotion and its moral and spiritual healthfulness. 'Taxwood' will secure for itself no secondary place in the literature of Scottish reminiscences."-Freeman. 
MACFARLANE-Principles of the Algebra of Logic, with Examples, by Alex. MacFarlaNe, M.A., D.Sc. (Edin.), F.R.S.E. 5s.

MACKAY-Memoir of Sir James Dalrymple, First Viscount Stair. A Study in the IIistory of Scotland and Scotcli Law during the Seventeentl Century. By L. J. G. MAckAy, Advocate. Svo, 12s.

MACKENZIE-Storms and Sunshine of a Soldier's Life. Lt.-General Colin Mackexzie, C. B., 1825-1881. With a Portrait. 2 rols. erown 8vo, $15 \mathrm{~s}$.

"Since the publication of Mr. Marsliman's 'Memories of Sir Henry Havelock,' some twenty years ago, we have received no bingraphy of this class with so sincere an admiration and so keen a delight."-Freman.

"Should be read by all who feel an iuterest in the history of British India during the last half century."-Nevectstle Courant.

" $A$ very readable biography . . . of one of the bravest and ablest officers of the East India Company's army."-Saturday Rveiew.

\section{MACLAGAN-Nugæ Canoræ Mledicæ.}

Lays of the Poet Laureate of the New Town Dispeusary. Edited by Professor Douglas Maclagax, 4to, With lllustrations, 7s.6d.

MACLAGAN - The Hill Forts, Stone Circles, and other Structural Remains of Aneient Scotland. By C. MACLAGAs, Lady Associate of the Society of Antiquaries of Scotland. With Plans and Illustrations. 1 vol. fol., 31 s. $6 \mathrm{~d}$.

"We need not cnlarge on the few inconsequential speculations which rigil archreologists may find in the present volume. We desire rather to commend it to their careful study, fully assured that not only they, but also the general reader, will be edified by its perusal."-Scotsman.

\section{M'LAREN-The Light of the World.}

By David M'LAREv, Minister of Humbie. Crown Sro, extra, 6s.

"We are conscious of having but very inadequately represented this raluable book, and can only hope that what we have said may lead all who have the oppor. tunity to study it for themselves."-Literary Jorld.

\section{M'LAREN-The Book of Psalms in Metre.}

According to the version approved of by the Church of Scotland. Revised by Rer. Datid M'LuREa. Crown Svo. is. $6 \mathrm{~d}$.

MACPHERSON-Omnipotence belongs only to the Beloved. By Mrs. Brewster Macphefsox. 1 vol. extra fcap., 3s. 6d.

\section{MAXWELL-Antwerp Delivered in MIDXXVII. :}

A Passage from the History of the Netherlands, illustrated with Facsimiles of a rare Series of Designs by Martin de Vos, and of Prints by Hogenberg, the Wierixes, ete. By Sil Willia Strrlixg-MAxwell, Bart., K.T. and M.P. In 1 vol. folio, 5 guineas.

"A splendid folio in richly ornamented binding, protected by an almost equally ornamental slip-cover. . . Remarkable illustrations of the namer in which the artists of the time "pursued their labours in a conntry ravaged by war, and in cities ever menaced by siege and sack." "-Scotsman. 
MAXWELL The History of Old Dundee, narrated out of the Town Council Register, with additions from Contemporary Annals. By Alexander Maxwell, F.S.A. Scot. In 1 vol. 4 to (to subscribers) $21 \mathrm{~s}$.

\section{MAYER-The Gun and Rod in America.}

Illustrated by the best Artists. Edited by Professor MAYER. In 2 vols. royal Svo, half-moroceo, gilt top.

"Sumptnous volnmes of a magnificence in design and excellence beyond anything else ever produced in the literature of American field sports."-Forest and Stream.

\section{MICHIE-History of Loch Kinnord.}

By the Rev. J. G. Michie. Demy Svo, 2s. 6d.

"It is throughout a piece of genuine, honest, literary workmanship, dealing thoroughly with its subject on the basis of careful study and personal inquiry and labour."-Aberdeen Free Press.

\section{MILN-Researches and Excavations at Carnac (Morbihan),}

The Bossenno, and Mont St. Michel. By JaMes MILn. In 1 vol. royal Svo, with Maps, Plans, and numerous Illustrations in Wood-Engraving and Chromolithography.

"Mr. Miln has made some interesting discoveries, and his record of then is simply and molestly written. He seems to have spared no pains either in making his excavations, or in writing and illustrating an acconnt of them. . . . Mr. Miln has thus an opportunity worthy of an ambitions arehrologist, and he has succeeded in using it well."-Saturday Review.

"This elegant volmme, one of those which are the luxury of art, is the work of an enthusiastic and well-informed antiquary."-British Quarterly.

MILN-Excavations at Carnac (Brittany), a Record of Archæological Researches in the Alignments of Kermario. By James MrLN. In 1 vol. royal Svo, with Maps, Plans, and numerons Illustrations in Wood-Engraving. 15s.

MITCHELI-The Past in the Present-What is Civilisation? Being the Rhind Lectures in Archrology, delivered in 1876 and 1878 . By Anthur Mirchell, M. D., LL.D., Secretary to the Society of Antiquaries of Scotland. In 1 vol. demy Svo, with 14 S Woodeuts, $15 \mathrm{~s}$.

"Whatever differences of opinion, however, may be held on minor points, there ean be no question that Dr. Miteliell's work is one of the ablest and most original pieces of archæological literature which has appeared of late years."-St. James's Gazette.

\section{MITCHELL-Our Scotch Banks:}

Their Position and their Policy. By Wr. Mrtcheld, S.S.C. Third Edition. Svo, 5s.

\section{MOLBECH-Ambrosius :}

A Play, translated from the Danish of Christian K. F. Molbech by ALICE Berry. Extra feap. Svo, 5s.

\section{MORETON-On Horse-Breaking.}

By Robert Moreton. Second Edition. Fcap. 8vo, 1s.

MUIR-Ecclesiological Notes on some of the Islands of Scotland, with other Papers relating to Ecclesiological Remains on the Scottish Mainland and Islands. By THoMAs $\mathrm{S}$. Mur, anthor of "Charaeteristies of Church Arclitecture," etc. In 1 vol. demry Svo, with numerous Illnstrations.

[In Preparation.

MUNRO-Ancient Scottish Lake-Dwellings or Crannogs, with a Supplementary Chapter on Remains of Lake-Dwellings in England. By RoBert MUNRo, M.D., F.S.A. Scot. 1 vol. deiny 8vo, profusely illustrated, price 21 s. 
"It is a most valuable aud incthodical statement of all the facts connected with his own excavations in Ayrshire. It will doubtless become a standard authority on the subject of which it treats."-Times.

"... Our readers may be assured that they will find very mucl to interest aud iustruct them in the perusal of the work."-Athencum.

". . . The issue of these reports in a handy volume was taken in hand by Dr. Munro, aud the result is seeu in the carefully-prepared and admirably got-up volume to which we have now to invite attention." - Saturday Review.

\section{NAPIER-"The Lanox of Auld:"}

An Epistolary Review of "The Lennox, by William Fraser." By Mark Napier. With Woodeuts and Plates. 1 vol. 4 to, 15 s.

"The spirit of chivalry survives, though the age is gone. If any one doubts it he has only to dip into the pages of 'Lanox of Auld.'. . . It places the reader in possession of both sides of the questions relating to the "Earldou of Lennox." Scotsman.

\section{NICHOLSON-Tenants' Gain not Landlords' Loss, and some} other Economic Aspects of the Land Question. By JoSEPH SHIELD Nicholson, M.A., Professor of Political Economy in the Uuiversity of Edinburgh. 1 vol. crown Svo, $5 \mathrm{~s}$.

\section{OBER-Camps in the Caribbees: Adventures of a Natu-} ralist in the Lesser Antilles. By Frederick OBER. Illustrations, demy 8vo, 12s.

"Well-written and well-illustrated uarrative of campiug out among the Caribbees."-Westminster Review.

"Varied were his experiences, hairbreadth his escapes, and wonderful his gleanings in the way of securing rare birds."-The Literary W'orld.

\section{OGG-Cookery for the Sick and a Guide for the Sick-Room.}

By C. H. OGG, an Edinburgh Nurse. Fcap. 1s.

OMOND-The Lord Advocates of Scotland from the close of the Fifteeuth Century to the passing of the Reform Bill. By G. W. T. Ososd, Advocate. 2 vols. demy 8 vo. $28 \mathrm{~s}$.

PATRICK, R. W. COCHRAN-Records of the Coinage of Scotland, from the earliest period to the Uuion. Collected by R. W. CochraNPATrick, M.P. Only two hundred and fifty copies priuted. Now ready, iu 2 vols. 4 to, with 16 Full-page Illustrations, Six Guineas.

"The future Historians of Seotland will be very fortunate if many parts of their materials are so carefully worked up for them and set before them in so complete and taking a form."- -Athenceum.

"When we say that these two volumes contain more than 770 records, of which more than 5.50 have never been printed before, aud that they are illustrated liy a series of Plates, by the autotype process, of the coins themselves, the reader may judge for himself of the leaming, as well as the pains, bestowed ou them both by the Author and the Publisher."-Times.

"The most handsome and complete Work of the kind which has ever been published in this country."-Numismatic Chronicle, Pt. IV., 1876.

"We have in these Records of the Coinage of Scotland, not the prodnction of a dilettante, but of a real student, who, with rare pains and the most scholarly diligence, has set to work and collected into two massive volumes a complete listory, of the coiuare of Scotlaud, so far as it can be gathered frou the ancient records." - Aculemy. 


\section{PATRICK-Farly Records relating to Mining in Scotland:}

Collected by R. W. Cochrax-Patrick, M.P. Demy 4to, 31s. 6d.

"The documents coritained in the body of the work are giveu without alteration or abridgment, and the introduction is writteu with ability and judgment, presenting a clear aud concise outline of the earlier history of the Mining Industries of Scotlaud."-Scotsman.

"The documeuts ... comprise a great deal that is very curious, and no less that will be important to the historiau in treating of the origin of one of the most important branches of the uatioual iudustry."-Duily News.

"Such a book . . . revealing as it does the first developments of an industry which has become the mainspring of the national prosperity, ought to be specially iuteresting to all patriotic Scotchueu."-Saturday Review.

\section{PATRICK-The Medals of Scotland: a Descriptive Cata-} logue of the Royal and other Medals relating to Scotland. By R. W. CochranPaTrıck, M.P., of Woodside. Dedicated by special permission to Her Majesty the Queeu. In 1 vol. 4to, with plates in faesimile of all the principal pieces.

\section{Phœbe.}

By the Author" of "Rutledge." Reprinted from the Fifth Thousaud of the American Edition. Crowu 8vo, 6s.

" "Plwobe' is a woman's uovel."-Saturday Revicw.

\section{Popular Genealogists ;}

Or, The Art of Pedigree-making. Crown Svo, $4 \mathrm{~s}$.

"We have here an agreeable little treatise of a hundred pages, from an anonymous bat evideutly competeut hand, on the ludicrous aud fraudulent sides of geuealogy. The subject has a serious and important listorical character, when regarled from the point of view of the authors of The Governing Families of Englencl. But it is rich iu the materials of comedy also.

"The first case selected by the writer before us is oue which has often excited our mirth by the very completeness of its unrivalled absurdity. Nobody can turn over the popular genealogical books of our day without dropping on a family called Conlthart of Coulthart, Collyn, and Ashtou-under-Lyne. The pedigree given makes the house beyond all question the oldest in Europe. Neither the Bombons nor Her Majesty's family can be satisfactorily earried beyoud the ninth eentury, whereas the Coultharts were by that time an old and distiuguished house.

"We are glad to see such a step takeu in the good work as the publication of the essay which has suggested this article, and which we commend to those who waut a bit of instructive aud amusing reading." - Pall Mall Gozette.

PORTER-The Gamekeeper's Manual : being Epitome of the Game Laws for the use of Gamekeepers aud otlers interested in the Preservation of Game. By Alexander Porter, Deputy Chief Constable of Roxburghshire. Fcap. 8vo, 1s.

\section{REID-Pictures from the Orkney Islands.}

By JoHs T. ReID, Author of "Art Rambles iu Shetlaud." In 1 vol. 4to, with numerous Illustrations, $25 \mathrm{~s}$.

\section{REITTON-Oils and Water Colours.}

By William ReNton. 1 vol. feap., 5s.

"The book is obviously for the Artist and the Poet, and for every one who shares with them a true love and zeal for nature's beauties."-Seotsman.

"To have observed such a delicate bit of colouring as this, aud to lave written so good a sonnet iu the 'strict style,' as that we have quoted, shows that our author has uo common powers either as au observer or a writer."-Liverpool Albion.

"To those minds that really hold this joy iu beauty, Mr. Rentou's book will undoubtedly give delight."-Northern Ensign. 
ROBERTSON -Kuram, Kabul, and Kandahar : being a Brief Record of the Impressions in Three Campaigns under General Roberts. By Lieut. RoBERTson, Sth, "The King's," Regiment. 1 vol. erown 8vo, with Maps, 6s.

\section{ROBERTSON-Historical Essays,}

In connection with the Land and the chureh, etc. By E. William Robertson, Author of "Scotland under her Early Kings." In 1 vol. 8vo, 10s. 6d.

\section{ROBERTSON-Scotland under her Early Kings.}

A History of the Kingdom to the close of the 13th century. By E. William Ropertson. In 2 vols. 8 vo, cloth, $36 \mathrm{~s}$.

"Mr. Rohertson's labours are of that valuable kind where an intelligent and thorough sifting of original authorities is brought to bear upou a portion of history handed over hitherto, in a pre-eminent degree, to a specially mendacious set of Medix val Chroniclers, and (not so long ago) to a specially polemical and uneritical elass of modern historians. He belongs to the school of Innes and skene and Joseph Robertson, and has established a fair right to be elassed with the Reeves aud Todds of Irish historical antiquarianism, aud the Sharpes, and Kembles, and Hardys in England."-Guarlian.

ROSEBERY - A Rectorial Address delivered before the Students of Aberdeen University, in the Music Hall at Aberdeen, ou Nov. 5, 1880. By LORD Rosebery. In demy Svo, price 6d.

\section{ROSEBERY - A Rectorial Address delivered before the}

Students of the University of Edinburgh, November 4, 1882. By LoRd Roseberr. Dewy 8vo, price 6d.

ST. JOHN-Notes and Sketches from the Wild Coasts of Nipon. With Chapters on Cruising after Pirates in Chinese Waters. By HENRY C. ST. Jorn, Captain R.N. In 1 vol. small demy 8vo, with Mlaps and Illustrations, price $12 \mathrm{~s}$.

Round Yesso.

The Inland Sea Revisited.

Currents and Typhoons.

A Summer's Walk in Kiusiu.

Deer-Shooting aud other matters.

The Kii Coast.

Insects.

Shooting, etc.

Singing-Birds and Flowers, ete.

Customs and Habits.

Past and Present.

Korea.

Cruising after Pirates.

Shooting in China.

More Cruising after Pirates.

Résumé.

"One of the most clarming books of travel that has bcen published for some time."-Scotsman.

"There is a great deal more in the book thau Natural History. . . . His pictures of life and manners are quaint and eftective, and the more so from the writing being natural and free from effort."-_.Athenceum.

"He writes with a simplicity and directness, and not seldom with a degree of graphic power, which, even apart from the freshness of the matter, render his book delightful reading. Nothing could be better of its kind than the deseription of the Inland Sea."-Daily News.

"He dedicates the volume in a few graceful sentences to the momory of his father, the well-known author of the "Wild Sports and Natural History of the Highlands,' etc. The son has certainly inherited the father's love of sport. . . Written in a perfectly simple and unpretending style, it bears evidence of much literary taste, and is eminently the work of a keen sportsman."-Aberdeen Free Press.

"The notes of so keen an observer of the habits of plants, insects, and animals, and on sea currents and storms, are not merely of curious interest in themselves, they will be of the highest value in illustrating the natural history and meteor- 
ology of a region which, from its situation and productions, is of singular interest to seience."-Scotsman.

"Clearly and tersely written, obviously the product of personal observation by one who is primarily a lover and observer of nature."-Inverness Courier.

"For seven years he was surveying in Japan, and this work is the fruit of his winter leisure. While coasting round Yesso and the Kuriles he constantly kept the dreige at work, and discovered nany new ereatures. He does not confine himself to natural history; he tells us a great deal more than even Miss Bird of life in the interior of Japan. The book will take high rank."-Graphic.

"His rough notes of their very prinitive ways are pleasantly put togethersome of these 'ways' being extremely 'peculiar,' according to European ideas, but with a strange mixture of good and evil. Supporters of foreign missions might do worse than study Captain St. John's remarks on the difference between the progress of Roman Catholic and Protestant missionary enterprise in the far East." North British Daily Mail.

\section{ST. JOHN-Notes on the Natural History of the Province}

of Moray. By the late CHARLES ST. JoHN, author of "Wild Sports in the Highlands." Second Edition. In I vol. royal 8vo, with 40 page Illustrations of Scenery and Animal Life. engraved by A. DURAND after sketehes made by GEORGE REid, R.S.A., and J. WYCLIFFE TAYLOR; also, 30 Pell-and-ink Drawings by the author in facsinile. Price 50s.

"This is a new edition of the work brought out by the friends of the late Mr. St. John iu 1S63; but it is so handsomely and nobly printed, and enriched with such charming illustrations, that we may consider it a new book."-St. James's Gazette.

"Charles St. Jolnn was not an artist, but he liad the habit of roughly sketching animals in positions which interested him, and the present reprint is adorned by a great number of these, facsimiled from the author's original pen and ink. Some of these, as, for instance, the studies of the golden eagle swooping on its prey, and that of the otter swimming with a salmon in its mouth, are very interesting, and full of that charm that comes from the exact transcription of unusual observa. tiou."-Pall Mall Gazette.

"The feature of the present edition is the series of beautiful sketches made specially for this volume by Mr. George Reid, R.S.A., and Mr. Wycliffe Taylor, together with numberless pieees from St. John's owu sketch-book introduced into the text. 'Roughness' they (the latter) certainly possess, almost as if St. John had thrown the inkstand at the paper, but withal a spirit of suggestiveness which makes them well-nigh unique among portraits of birds and other animals, and we cannot be too grateful to the editor for presenting them in this form." -Nation (New York).

\section{ST. JOHN-A Tour in Sutherlandshire, with Extracts from}

the Field-Books of a Sportsman and Naturalist. By the late Charles St. JoHN, author of "Wild Sports and Natural History in the Highlands." Second Edition, with an Appendix on the Fauna of Sutherland, by J. A. HARvie-Brown and T. E. BUCKLEY. Illustrated with the original wood-engravings, and additional vignettes from the Author's sketch-books. In 2 vols., sinall deny 8vo, 21s.

\section{SCHIERN-Life of James Hepburn, Farl of Bothwell.}

By Professor Schiern, Copenhagen. Translated from the Danish by the Rev. David Berry, F.S.A. Scot. Demy 8vo, 16s.

"The real interest in the book lies in the information which it contains about the life of Bothwell after the surrender at Carberry. The only trustworthy information concerning the latter period of his life must be sought from Scandinavian sources."

"Not only well written and interesting, but at the same time so thoroughly trustworthy that it can well bear the test of close critical examination."-Saturday Review. 


\section{Scoteh Folk.}

Illustrated. Third Edition enlarged. Ex. fcap. Svo, price 1s.

"They are stories of the best type, quite equal in the main to the average of Dean Ramsay's well-known collection."-Aberdeen Free Press.

\section{SHAIRP-Studies in Poetry and Philosophy.}

By J. C. Shair., LL.D, Principal of the United College of St. Salvator and St. Leonard, St. Andrews. Second Edition. I vol. feap. Svo, 6s.

"In the 'Moral Dynamic,' Mr. Shairp seeks for something which sliall persuade us of the vital and close bearing on each other of moral thought and spiritual energy. It is this conviction which has animated Mr. Shairp in every page of the volume before us. It is because lie appreciates so justly and forcibly the powers of philosoplic doctrine over all the field of human life, that he leans with such strenuous trust upon those ideas which Wordsworth nusystematically, and Coleridge nore systematically, made popular and fertile among us."-Saturiay Review.

"The fincst essay in the volume, partly because it is upon the greatest and most definite subject, is the first, on Wordsworth. . . . We have said so much unon this essay that we can only say of the other three that they are fully worthy to stand beside it."-Spectator.

\section{SHAIRP-Culture and Religion.}

By Principal Sharrp, LL.D. Seventh Edition. Fcap. Svo, 3s. 6d.

"A wise book, and unlike a great many other wise books, has that carefully shaded thought and expression which fits Professor shairp to speak for Culture no less than for Religion."- Spectator.

"Those who remember a former work of Principal Shairn's, 'Studies in Poetry and Philosophy,' will feel secure that all which comes from his pen will bear the marks of thought, at once careful, liberal, and accurate. Nor will they be disappointed in the present work. . . . We can recommend this book to our readers."-Athencum.

"We cannot close fwithout earnestly recommending the book to thoughtful young men. They will find in it the work of a cultivated and learned mind, and of a pure, generous, and upright heart. It combines the loftiest intellectual power with a simple and childlike faitl in Christ, ancl exerts an influence which must be stimulating and healthful."-Freeman.

\section{SHAIRP-On Poetic Interpretation of Nature.}

By J. C. Shairp, LL.D., Principal of the United College of St. Salvator and St. Leonard, St. Andrews. Second Edition. In 1 vol. ex. feal. Svo, $6 \mathrm{~s}$.

"There is a real sense of relief and refreshnent on turning from the news of the day to the unspeakable repose of nature, and in the sense of coolness, and stillness, and greenness, of which we become conscious as we follow Professor Shairl through these interesting and suggestive pages."-Times.

SHAIRP-Wordsworth's Tour in Scotland in 1803, in Company with his Sister and S. T. Coleridge; being the Journal of Miss WonDswokTH, now for the first time made public. Edited by Principal Shairp, LL.D. Second Edition. 1 vol, erown Svo, 6s.

"If there were no other record of her than those brief extracts from IJer Journal during the Highland Tour, which stand at the head of several of her brother's poems, these alone would prove her possessed of a large portion of his genius."North British Review.

"The rolume glistens with passages nearly as clarming, showing low rich in "Wordsworthian" faney was this modest sister. . . We have to thank Dr. Shairp, and the thanks must be hearty, for now for the first time giving them in a complete form."-Athenceum. 
"All who love Wordsworth and Nature will welcome this book. To many it will add a more precious seeing to the eye, and make them understand how, if they look, they will see."-Scotsman.

" Next to the charming simplicity we like the quiet, picturesque power of this diary."-Dundee Advertiser.

"The book is one to be read and prized-to be read through with delight, and to be often taken up again with an over-full enjoyment."-Daily Review.

"A simple, and in many respects a touching record is this, brimming over with sisterly love-womanly, tender, and graceful."-Standard.

"Many readers will turn with a pure delight from nental wars and questions to wander amid the grandeur and beauty of Scottish glens and mountains in the company of so bright a being as Dora Wordsworth, the loved and loving sister of the poet.-Windsor Gazette.

"As a picture of Scotland seventy years ago, there is not in the whole compass of English Literature a work that can be said to equal or even approach this one."-Literary World.

" The "Journal' would be worth reading if it were only for the sake of finding these lines in their proper place: "IVhat? you are stepping Westward? Yea." Acalemy.

"It will extend the fame of Wordsworth, and cause many who know him not, or are little acquainted with his writings, to become his admirers; and evermore with us the name 'Dorothy' shall be inelodious as the name of one who is a sweet-souled benefactress of our race."-Aberdeen Herald.

\section{SHAIRP-Kilmahoe, a Highland Pastoral,}

And other Poems. Feap. Svo, 6s.

SIBBALD-The Divine Comedy of Dante Alighieri, The Inferno. A Translation in Terza Rima, with Notes and Introductory Essay. By James Romanes SibBald. With an Engraving after Giotto's Portrait, In One Volume, small Demy Svo. Price 12s.

\section{SIMPSON-The Near and the Far View,}

And other Sermons. By Rev, A. L. Simpson, D.D., Derby. 1 vol. ex. feap. 8vo, 5s.

"Very fresh and thoughtful are these sermons."-Literary World.

- "Dr. Simpson's sermons may fairly claim distinetive power. He looks at things with his own eyes, and often shows us what with ordinary vision we had failed to perceive. ... The sermons are distinctively good."-British Quarterly Review.

\section{SIMPSON-Archæological Essays.}

By the late Sir James Simpson, Bart. Edited by the late John StUART, LL.D. 2 vols. 4 to, $21 \mathrm{~s}$.

1. Archæology.

2. Incheolm.

3. The Cat Stane.

4. Magical Charm-Stones.
5. Pyranid of Gizeh.

6. Leprosy and Leper Hospitals.

7. Greek Medical Vases.
S. Was the Roman Army provided with Medical Officers? [etc. etc.

9. Roman Medicine Stamps,

\section{SKENE-The Four Ancient Books of Wales,}

Containing the Cymric Poems attributed to the Bards of the sixth century. By WilliaM F. SkENe, Historiographer-Royal for Scotland. With Maps and Facsimiles, 2 vols. 8 vo, $36 \mathrm{~s}$.

"Mr. Skcne's book will, as a matter of course and necessity, find its place on the tables of all Celtic antiquarians and scholars."-Archoeologia Cambrensis. 


\section{SKENE-Celtic Scotland: A History of Ancient Alban.}

In Three vols, 45s. Illustrated with Maps.

I.-History and Ethxology. II.-Church and Culture.

$$
\text { III.-LAND and PEOPLe. }
$$

"Forty years ago Mr. Skeue publisherl a small historical work on the Scottish Highlands which has ever since been aprealed to as an anthority, but which has long been out of print. The promise of this youthful effort is amply fulfilled in

!. the three weighty volumes of lis maturer years. As a work of historical research it ought in our opinion to take a very ligh rank." - Times.

\section{SKENE-The Gospel History for the Young:}

Being lessons on the Life of Christ, Adalıted for use in Families and Sunday Schools. By Willam F. Skene, D.C.L., Historiographer-Royal for Scotland. Small erown Svo, in Three vols., with Maps, 5s. each vol.

"In a spirit altogether unsectarian, lrovides for the young a simple, interesting, and thoroughly claruing history of our Lord."-Literary World.

"This 'Gospel llistory for the Young' is one of the most valuable books of the kind."-The Churchman.

SMALL-Scottish Woodwork of the Sixteenth and Seventeenth Centuries. Measured, Drawn, and Litlographed by J. W. SHaLL, Arehitect. In one folio volume, with 130 Plates, Four Guineas.

"Mr. J. W. Small's very admirable volume, illustrative of ancient Scottish woodwork. ... It is impossible to over-estimate the value of the minnte details that abound in MIr. Small's admirable work. Very opportunely lias Mr. Small come to the reseue of art furnitnre with his admiralle work, of which it is impossible to speak in unduly eulogistic terms."-Fumiture Gazette.

\section{SMITH-Shelley: a Critical Biography.}

By George Barnett Smith, Ex. feap. Sro, 6s.

\section{SIMITH-The Sermon on the Mount.}

By the Rev. Walter C. Smint, D.D. Crown Sto, 6s.

\section{SMITH-Answer to the Form of Libel before the Free} Presbytery of Aberleen. By W. Robertson SMith, Professor of Oriental Languages aud Exegesis of the Ohd Testament in the Free Cliurch College, Aberdeen. Svo, is.

\section{SMITH-Additional Answer to the Libel,}

With some Account of the Evidence that parts of the Pentatenchal Law are later than the Time of Moses. By W. Roberrson Surs, Professor of Oriental Languares aud Exegesis of the Old Testament in the Free Cliurch College, Aberteen. Svo, 1s.

SMITH-Answer to the Amended Libel, with Appendix coutainiug Plea in Law. By W. Robertson sitth. Svo, 6 d.

SIMITH-Open Letter to Principal Rainy. $6 \mathrm{~d}$.

SMITH-The Papal Authority, as affirmed by Pius IX. and the Vatican Council, considered botl as a Theological Doctrine and in its bearings on Political Liberty. (The Gordon Priz. Essay.) By Rev. JuHN Surth, Free Chureh Minister of Tarlanr. small crovu svo, price ls.

SMYTH-Life and Wurk at the Great Pyramid.

With a Disenssion of the Facts ascertainel. By C. Pıazi SMYTH, F.R.SS.L. and E., Astronomer-Royal for scotlani. 3 vols. deny Svo, 50 s. 
SMYTH-Madeira Meteorologic:

Being a Paper on the above snbject real before the Royal Society, Edinburgh, on the lst of May 1882. By C. PJAzzI Sмyтh, Astronomer-Royal for scotland. In 1 vol. small 4 to, price $6 \mathrm{~s}$.

\section{SOUTHESK-Saskatchewan and the Rocky Mountains.}

Diary and Narrative of Travel, Sport, and Adventure, during a Journey through part of the Hudson's Bay Company's Territories in 1859 and 1860. By the EARL of Southesk, K.T., F.R.G.S. 1 vol. demy svo, with Illustrations on Wood by WHYMPER, 1Ss.

\section{SOUTHESK-Herminius :}

A Romance. By I. E. S. Fcap. Sro, 6s.

\section{SOUTHESK-Jonas Fisher:}

A Poem in Brown and White. Cheap Edition. Price 1s.

SOUTHESK - The Burial of Isis and other Poems.

Feap. Svo.

\section{SPEDDING. See GAIRDNER.}

\section{SPENS-Darroll, and other Poems.}

By Walter Cook Spens, Advocate. Clown Svo, 5 s.

"This volume will repay perusal. It is one which could have been written only by a man of culture."-Daily lieview.

"He writes with feeling, and displays considerable facility in the handling of almost every ordinary variety of inetre." - Scotsman.

SPENS-Should the Poor-Law in all Cases deny Relief to the Able-bodied Poor? By Walter Cook SPENs, Advoeate, Sheriff-Substitnte of Lanarkshire. Demy Svo, is.

SPINNAKER-Spindrift from the Hebrides.

By SPINNaKer. With Eight Etchings, Crown 8vo, 1s, 6d.

\section{STOCKTON-Rudder Grange.}

By Frank R. Stockton. 1 vol. $32 \mathrm{mo}, 1 \mathrm{~s}$; ; and clotl, $2 \mathrm{~s}$.

"It may be safely recommended as a very amusing little book."-Athenceum.

"The style has an engaging freshness and nairete, and the amusing situations, of which the book is full, are lit off with mnch hnmour of the more delicate order." -Glasgow News.

"This is a volnne of American hnmour, puxe and sparkling as lemonade."- Aberdeen Free Press.

"Altogether 'Rudder Grange' is as cheery, as hnmorons, and as wholesome a little story as we have read for many a day."-St. Jumes's Gaztte.

"The minutest incidents are narrated with snch genuine humour and gaiety, that at the close of the volmme the reader is sorry to take leave of the merry innocent party."-Westminster Feview.

STOCKTON- The Lady or the Tiger? and other Stories.

By Frank R. Stockton. 32mo, 1s. ; and cloth, 2 s.

STEVENSON - Christianity Confirmed by Jewish and Heathen Testimony, and the Deductions from Pliysical Seience, ete. By Thоваs Stevenson, F.R.S.E., F.G.S., Member of the Institution of Civil Engineers. Second Edition. Feap. Svo, 3s. 6d. 


\section{STRACHAN-What is Play?}

A Physiological Inquiry. Its bearing upon Education and Training. By Jors Strachax, M.D., Jun. In 1 vol. feap., 1s.

"We have great pleasure in directing the attention of our readers to this little work . . bearing as it does on one of the most important aspects of physiological medicine, as well as on education in the highest seuse of the word."-Lancet.

"A very interesting, and, in the main, a wise little book."-Mind.

"It is so seldom that so much sound sense, clear reasoning, and able developmeut of ileas, which will probably be new to the majority of readers, are conpressed into a hundred duodecino pages, as Dr. Strachau has contrived to put into his little treatise on Play."-Scotsman.

\section{SYMINGTON-Good Lives: Some.Fruits of the Nineteenth}

Century. By A. M. Srmisaton, D.D. 1 vol., small crown Svo, 3s. 6 d.

\section{TAIT-Sketch of Thermodynamics.}

By P. G. TA1T, Professor of Natural Plilosophy in the University of Edinburgh. Second Edition, revised and extended. Crown 8vo, 5s.

\section{Talks with our F'arm-Servants.}

By An Old Farm-Servant. Crowu Svo; paper 6d., eloth 1s.

\section{THOREAU-Walden; or, Life in the Woods.}

By H. D. Thoreau. In 1 vol, crown svo, $6 \mathrm{~s}$.

\section{Tommie Brown and the Queen of the Fairies; a new Child's}

Book, in feap. Svo. With Illustrations, 4 s. $6 \mathrm{~d}$.

$$
\text { Let pain be pleasure, and pleasure be pain. }
$$

"There is no wonder that children liked the story. It is told neatly and well, and is full of great cleverness, while it has that peculiar eharacter the absence of which from many like stories deprives them of any real interest for childreu."-Scotsman.

"The story is a delightful bit of fancy, primarily calculated to create wonderment in the youthful mind, but none but the dullest reader will turn over the pages of the engrossing narrative without discovering that the author inculeates numerous lessons of the most wholesome kind."-Daily lieview.

"The author has eontributed a story which could not fail to delight the hearts of fairy-tale loving children."-Aberdeen Free Press.

\section{TROTTER-Our Mission to the Court of Maroceo in 1880 ,}

under Sir Johx Drumsond Hay, K.C.B., Minister Plenipotentiary at Tangier, and Euvoy Extraordinary to His Majesty the Sultau of Maroceo, By Captain PinlıP DURhaм Trotтer, 93d Highlanders. Illustrated from Photographs by the Hon. D. LAwLess, Rifle Brigade. In 1 rol, square demy Svo, $24 \mathrm{~s}$.

"Very attractively written .... not only highly instructive but also extremely amusing."-Times.

"There is much in this book which is well worth rearling, and the author's style is always lively. The illustrations of the most interesting places and ruins are from photographs taken by Mr. Lawless, and are very successful."-Guardian.

\section{The Book-Lover's Enchiridion: a Selection of Thoughts on}

the Solace and Companionship of Books. $6 s$. 
The Upland Tarn: A Village Idyll.

In 1 vol, small crown, price 5s.

WHITE-Mr. Washington Adams in England.

By Richard Grant White. In 1 vol. price 1s.; or in clotli $2 \mathrm{~s}$.

"One of the most practically useful of the shilling series of American authors." -Greenoch Telegraph.

"An impudent book."-Vanity Fair.

"This short, tiresome book."-Saturday Review.

"Brimful of geuuine humour."-Montrose Standard.

"Mr. White is a capital caricaturist, but in portraying the ludicrous eccentricities of the patrician Britisher he hardly suceeds so well as in deliueating the peculiar charmus of the representative Yankee." - Whitehall Review.

\section{WILSON-The Botany of Three Historical Records:}

Pharaoh's Dream, The Sower, aud the King's Measure. By A. Stephen Wilson. Crowu Svo, with 5 plates, $3 \mathrm{~s}$. $6 \mathrm{~d}$.

"The book is useful as affording illustrations of Scripture incident and teaching."-Inverness Courier.

"The writer deserves credit for the pains he has taken in making his researches, and by meaus of well-designed woodcuts he has so illustrated the work as to malie his arguments as clear as is possible."-Courant.

\section{WILSON_-'A Bushel of Corn.'}

By A. Stephen Wilson. An investigation by Experiments into all the more important questions which range themselves round a Bushel of Wheat, a Bushel of Barley, aud a Bushel of Oats. In 1 vol. crowu 8vo, with Illustrations, $9 \mathrm{~s}$.

"It is full of originality and force."-Nature.

"A monument of painstaking research."-Liverpool Merenry.

"Mr. Wilson's book is interesting not only for agriculturists and millers, but for all who desire information on the subject of corn, in which every one is so intimately concerned."-Morning Post.

\section{WILSON-Songs and Poems.}

By A. Stephen Wilson. Crown Sro.

\section{WILSON-Reminiscences of Old Edinburgh.}

By Daniel WiLson, LL.D., F.R.S.E., Professor of History and English Literature in Uuiversity College, Toronto, Author of "Prehistoric Annals of Scotland," etc. etc. 2 vols. post Svo, 15 s.

WYLD-Christianity and Reason:

Their necessary connection. By R. S. WyLd, LL.D. Extra fcap. Svo, 3s, 6d.

Edinburgh : David DOUGLas, 15 Castle Street. 



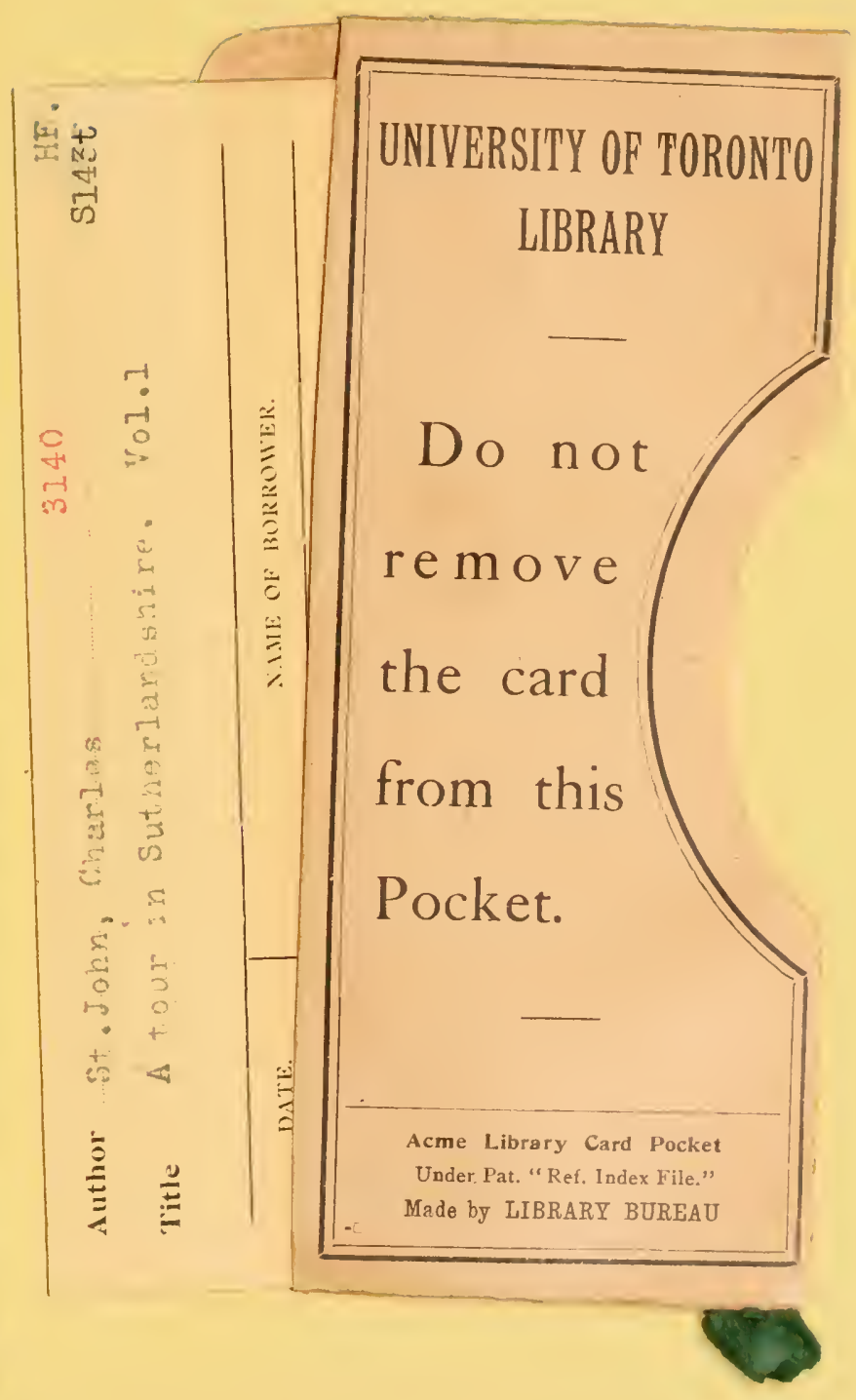


